\title{
Archaeological Testing to Determine the National Register Eligibility Status of 18 Prehistoric Sites on Camp Bowie, Brown County, Texas Volume 2
}

Raymond P. Mauldin

Center for Archeological Research, University of Texas at San Antonio

David L. Nickels

Cory J. Broehm

Follow this and additional works at: https://scholarworks.sfasu.edu/ita

Part of the American Material Culture Commons, Archaeological Anthropology Commons, Environmental Studies Commons, Other American Studies Commons, Other Arts and Humanities Commons, Other History of Art, Architecture, and Archaeology Commons, and the United States History Commons

Tell us how this article helped you.

This Article is brought to you for free and open access by the Center for Regional Heritage Research at SFA ScholarWorks. It has been accepted for inclusion in Index of Texas Archaeology: Open Access Gray Literature from the Lone Star State by an authorized editor of SFA ScholarWorks. For more information, please contact cdsscholarworks@sfasu.edu. 
Archaeological Testing to Determine the National Register Eligibility Status of 18 Prehistoric Sites on Camp Bowie, Brown County, Texas Volume 2

\section{Creative Commons License}

\section{(c) (1) \&}

This work is licensed under a Creative Commons Attribution-NonCommercial 4.0 International License 


\section{Archaeological Testing to Determine the National Register Eligibility Status of 18 Prehistoric Sites on Camp Bowie, Brown County, Texas}

\section{Volume 2}
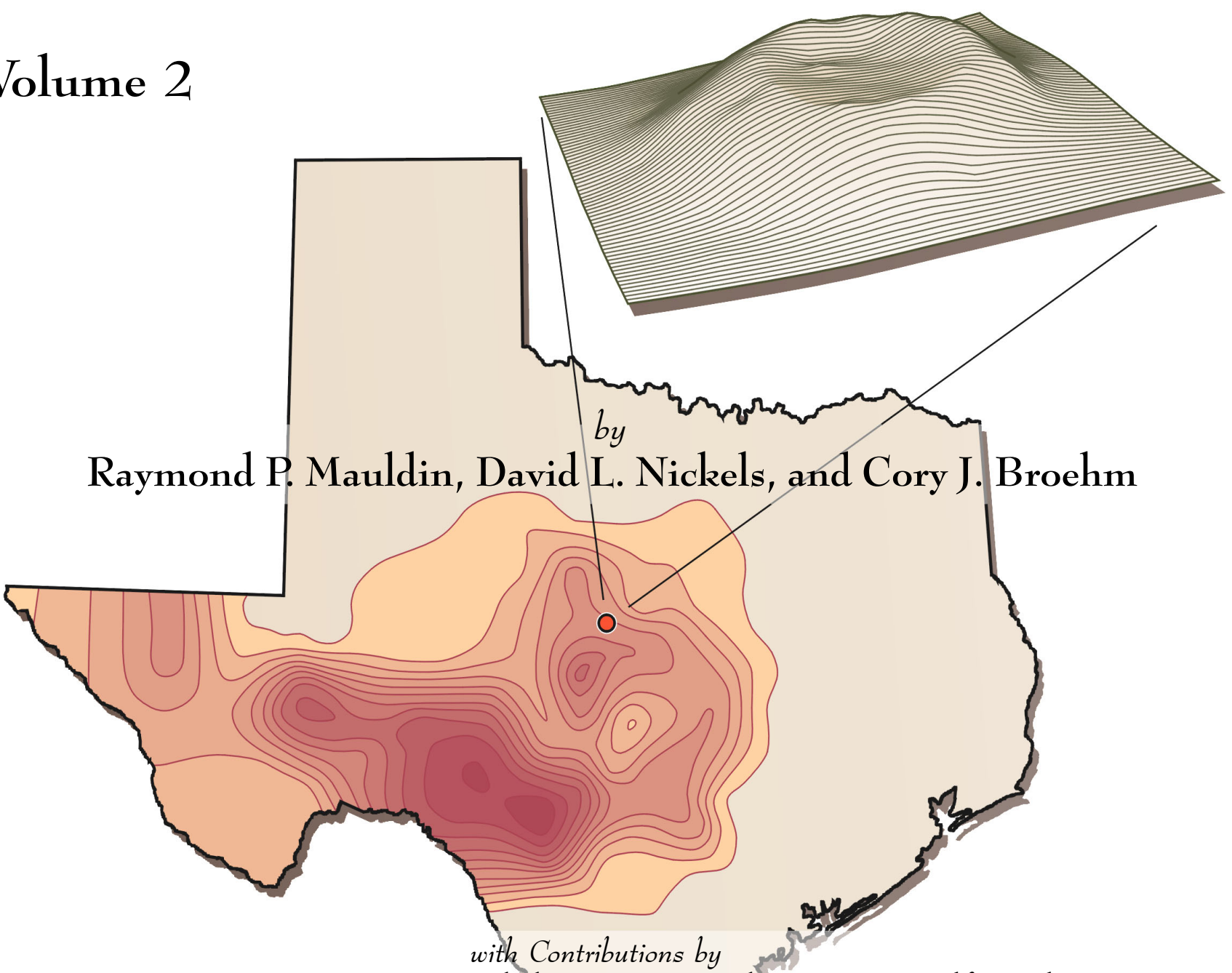

C. Britt Bousman, J. Philip Dering, Glenn A. Goodfriend, Linda Hodges, Jeffrey R. Francis, and Barbara A. Meissner

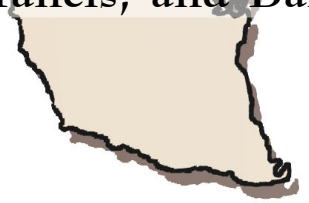

Adjutant General's Department of Texas Directorate of Facilities and Engineering Environmental Branch, Austin, Texas
Center for Archaeological Research The University of Texas at San Antonio Archaeological Survey Report, No. 334 

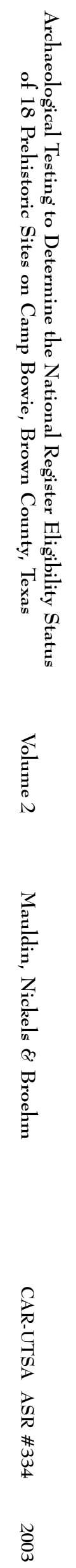


\section{Archaeological Testing to Determine the National Register Eligibility Status of 18 Prehistoric Sites on Camp Bowie, Brown County, Texas}

\section{Volume 2}

by

Raymond P. Mauldin, David L. Nickels, and Cory J. Broehm

with Contributions by

C. Britt Bousman, J. Philip Dering, Glenn A. Goodfriend, Linda Hodges, Jeffrey R. Francis, and Barbara A. Meissner

Texas Antiquities Committee Permit No. 2310

Raymond P. Mauldin

Principal Investigator

Robert J. Hard, former Principal Investigator

Prepared for:

Adjutant General's Department of Texas Directorate of Facilities and Engineering Environmental Branch, Austin, Texas
Prepared by:

Center for Archaeological Research

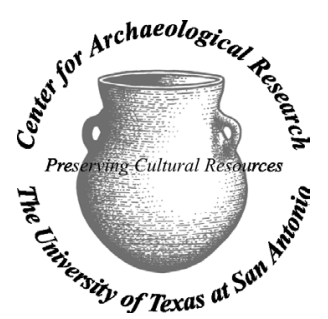
The University of Texas at San Antonio Archaeological Survey Report, No. 334 
The following information is provided in accordance with the General Rules of Practice and Procedure, Chapter 26.24 (Investigative Reports), Texas Antiquities Committee:

1. Type of investigation: Testing

2. Project name: Camp Bowie Testing of 18 Sites

3. County: Brown

4. Principal investigators: Raymond P. Mauldin

5. Name and location of sponsoring agency: Adjutant General's Department of Texas

6. Texas Antiquities Permit No.: 2310

7. Published by the Center for Archaeological Research, The University of Texas at San Antonio, 6900 N. Loop 1604 W., San Antonio, Texas 78249-0658, 2003

A list of publications offered by the Center for Archaeological Research is available. Call (210) 458-4378; write to the Center for Archaeological Research, The University of Texas at San Antonio, 6900 N. Loop 1604 W., San Antonio, Texas 78249-0658; e-mail to car@lonestar.utsa.edu; or visit CAR's web site at http://car.utsa.edu.

Cover Figure: density map of the percentage of burned rock middens across Texas, with a surface plot of the burned rock midden on site 41BR492.

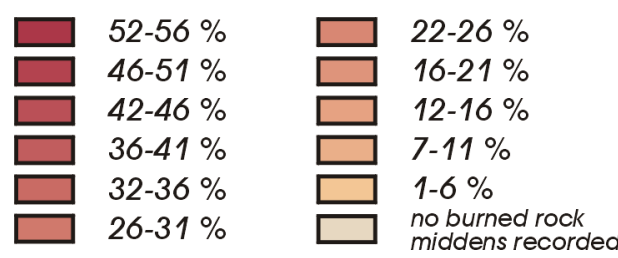




\section{Abstract}

Between the fall of 1999 and the summer of 2001, archaeologists from the Center for Archaeological Research (CAR) at The University of Texas at San Antonio conducted National Register Eligibility testing on 18 prehistoric sites within Camp Bowie in Brown County, Texas. The work was conducted for the Texas Army National Guard. The sites were recommended for testing during an inventory survey of Camp Bowie conducted between 1993 and 1998 (Wormser and Sullo-Prewitt 2001). Sixteen of the 18 sites tested contained burned rock middens. It was on the basis of that feature type that these sites were recommended for testing. Two sites (41BR261 and 41BR276) lacked burned rock middens, but Wormser and Sullo-Prewitt (2001) recommended these sites for testing based on the presence of diagnostic projectile points and the potential for buried features. As burned rock middens were a major element of the recommendations, much of this report focused on understanding those feature types. In all, 19 middens were tested.

On the basis of these testing efforts, CAR recommends that 12 sites (41BR65, 41BR87, 41BR228, 41BR246, 41BR250, 41BR253, 41BR420, 41BR433, 41BR473, 41BR478, 41BR492, and 41BR493) should be considered eligible for inclusion to the National Register of Historic Places and warrant designations as State Archeological Landmarks. Either avoidance of these locations, or some form of mitigation on portions of these sites, will be necessary. Our testing suggests that the remaining sites either lack clear evidence of significant data (41BR261 and 41BR276) or have data of questionable integrity (41BR415, 41BR441, 41BR474, and 41BR480). In these cases, CAR recommends that these sites are not eligible for inclusion to the National Register of Historic Places and they do not warrant designation as State Archeological Landmarks. 
NRHP Testing of 18 Prehistoric Sites on Camp Bowie, Brown County, Texas Volume Contents

Volume 1

Chapter 1: Project Overview

Chapter 2: The Environmental Setting of Camp Bowie

Chapter 3: Archaeological Background

Chapter 4: Background and Research Issues

Chapter 5: Testing Methods and Levels of Effort

Chapter 6: Individual Site Testing Summaries

Chapter 7: Chronological Placement of Camp Bowie Burned Rock Middens

Chapter 8: Development of Burned Rock Middens at Camp Bowie

Chapter 9: Subsistence Issues in Camp Bowie Middens

Chapter 10: Investigating Midden Sites at Camp Bowie

Chapter 1 1: Burned Rock Middens in Texas

Chapter 12: Recommendations

Volume 2

Appendix A: Radiocarbon Results

Appendix B: Vertebrate Faunal Remains

Appendix C: Ethnobotanical Remains

Appendix D: Mussel Shell Analyses

Appendix E: Recovered Projectile Points

Appendix F: Selected Other Tools

Appendix G: Geomorphology

Appendix H: Magnetic Sediment Susceptibility Testing

Appendix I: Description of Human Remains

Appendix J: Diagnostic Artifacts from Burned Rock Middens 


\section{Table of Contents: $\quad$ Volume 2}

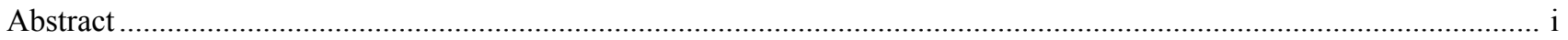

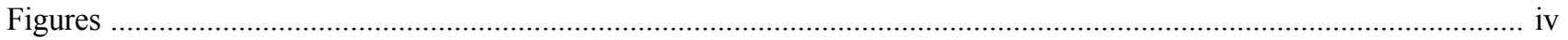

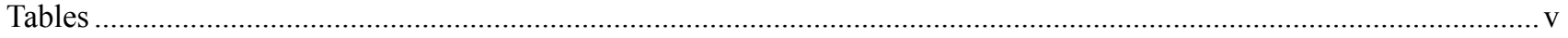

Appendix A: Radiocarbon Results

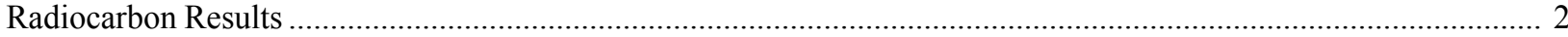

Appendix B: Vertebrate Faunal Remains by Barbara A. Meissner

Vertebrate Faunal Remains

Appendix C: Ethnobotanical Remains by J. Philip Dering

Botanical Perspectives on Land Use in the Cross Timbers and Prairies ............................................................... 58

Appendix D: Mussel Shell Analyses by Glenn A. Goodfriend

Mussel Shell Analyses .....

Appendix E: Recovered Projectile Points

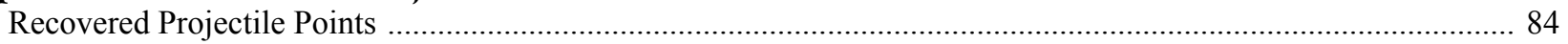

Appendix F: Selected Other Tools

Selected Other Tools

Appendix G: Geomorphology by C. Britt Bousman and Linda Hodges

The Geology of Archaeological Sites on Camp Bowie .....

Appendix H: Magnetic Sediment Susceptibility Testing by Raymond P. Mauldin

Magnetic Sediment Susceptibility Testing

Appendix I: Description of Human Remains by Jeffrey R. Francis

Description of Human Remains

Appendix J: Diagnostic Artifacts from Burned Rock Middens in 13 Counties in Texas

Diagnostic Artifacts from Burned Rock Middens in 13 Counties in Texas 


\section{Figures:}

\section{Volume 2}

Figure C-1. Geophytes with globose bulbs or tubers that grow in the study area....................................................... 60

Figure C-2. Carbonized geophytic remains from Horn Shelter. Note differences in gross morphology. .......................... 61

Figure C-3. Inner surface bulb scale epidermis from four common geophytes (100X). ................................................ 62

Figure C-4. Outer surface bulb scale epidermis from four common geophytes (100X)................................................ 63

Figure C-5. Bulb scale epidermal patterns of Drummond onion (Allium; 100X)...................................................... 63

Figure C-6. Similar epidermal patterns: Drummond onion, camas, and prairie celestial (100X). ................................. 64

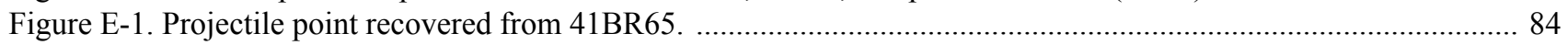

Figure E-2. Projectile points recovered from 41BR87. .................................................................................... 84

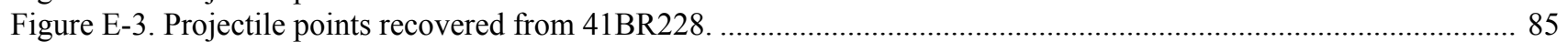

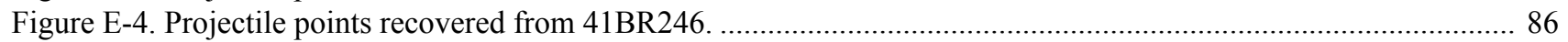

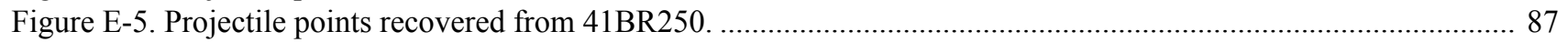

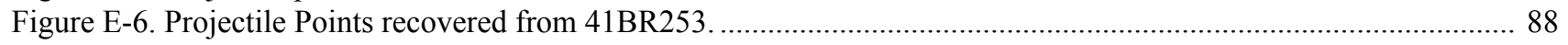

Figure E-7. Projectile point recovered from 41BR261. ..................................................................................... 88

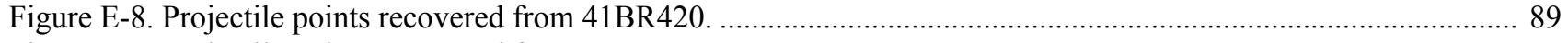

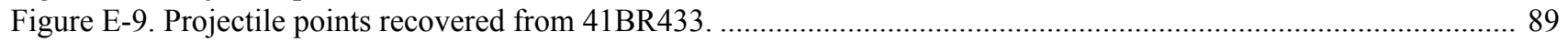

Figure E-10. Projectile point recovered from 41BR441. ................................................................................... 90

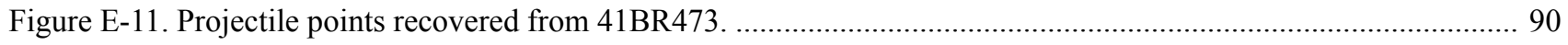

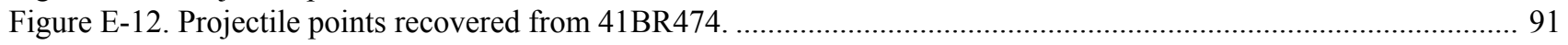

Figure E-13. Projectile points recovered from 41BR478. .................................................................................. 91

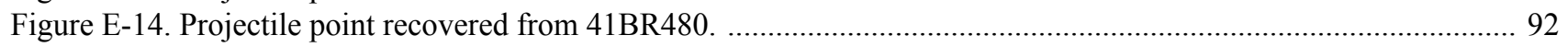

Figure E-15. Projectile points recovered from 41BR492 .................................................................................. 92

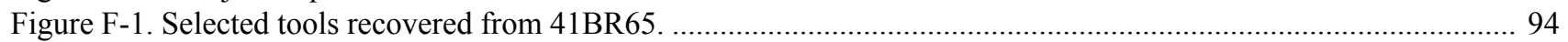

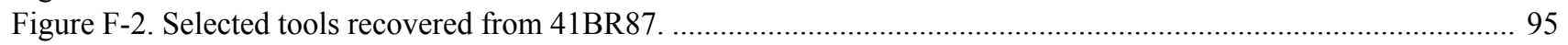

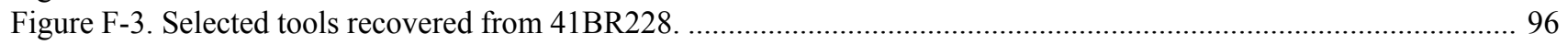

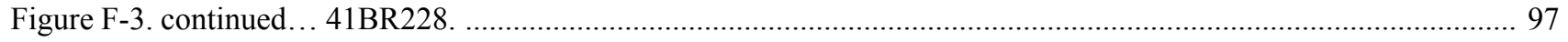

Figure F-4. Ceramic sherd recovered from 41BR228. ....................................................................................... 98

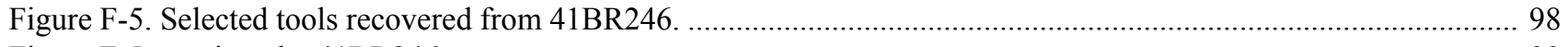

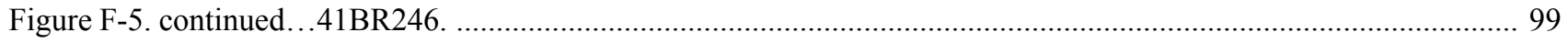

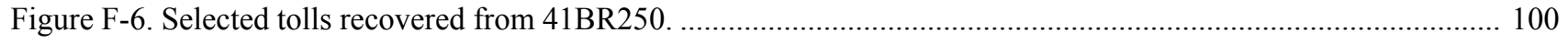

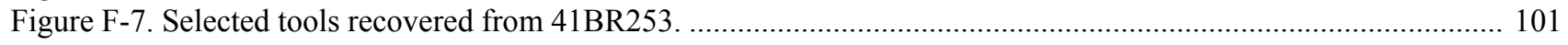

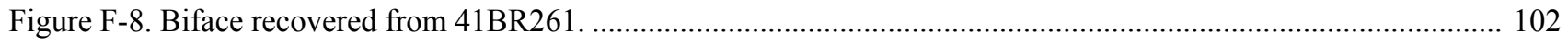

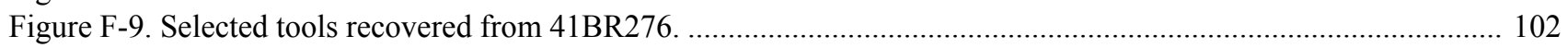

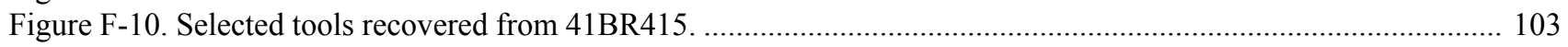

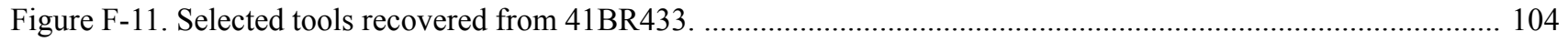

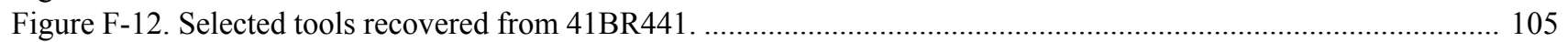

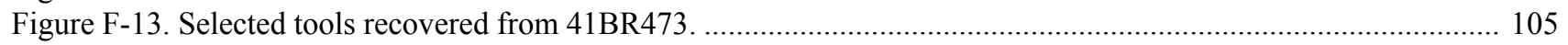

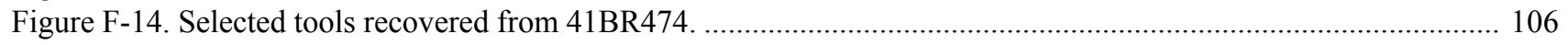

Figure F-15. Selected tools recovered from 41BR478. .................................................................................. 107

Figure F-16. Selected tools recovered from 41BR480 .................................................................................... 108

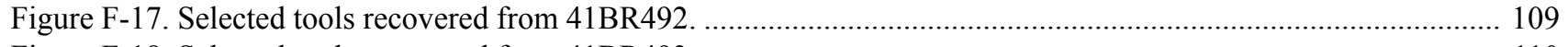

Figure F-18. Selected tools recovered from 41BR493. ........................................................................................ 110 


\section{Tables:}

\section{Volume 2}

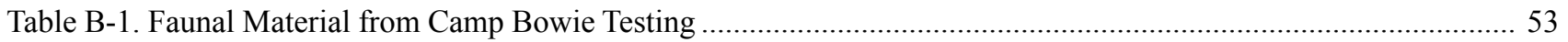

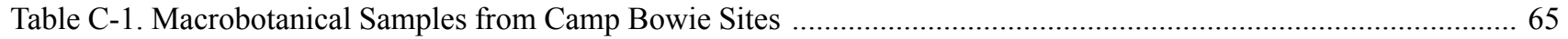

Table C-2. Plant Remains from Flotation Samples ................................................................................................. 68

Table C-3. Occurrence of Geophyte Remains from Archaeological Sites in Texas ....................................................... 73

Table D-1. Selected Mussel Shell Identifications from Camp Bowie Sites ................................................................ 80

Table D-2. A/I ratios and Asp/Glu ratios for Quadrula from Camp Bowie Sites ........................................................ 82

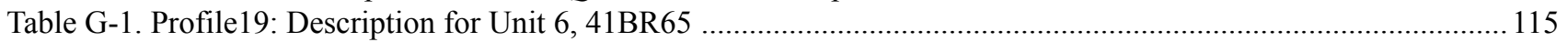

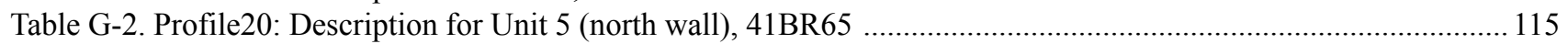

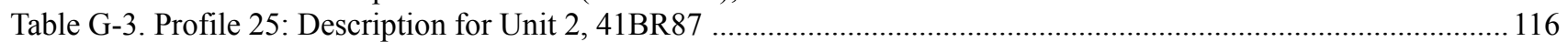

Table G-4. Profile 9: Description for Unit 1 (burned rock midden on saddle), 41BR228 .......................................... 117

Table G-5. Profile 10: Description for Unit 3 (burned rock midden on saddle), 41BR228 ........................................... 117

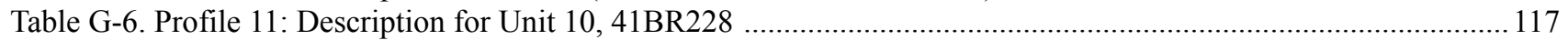

Table G-7. Profile 12: Description for Unit 8, 41BR228, midden unit of Unit 10 above and Unit 9 below .................... 118

Table G-8. Profile 13: Description for Unit 9 (slightly below Unit 9), 41BR228 ……............................................... 118

Table G-9. Profile 18: Description for Units 2 and 3 (west wall), 41BR250 ............................................................ 119

Table G-10. Profile 39: Description for Backhoe Trench, 41BR250 ….................................................................. 119

Table G-11. Profile 14: Description for Unit 10, 41BR253 .............................................................................. 120

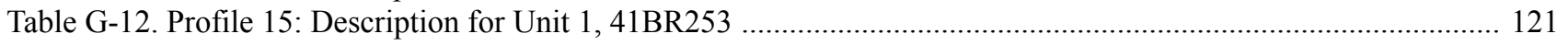

Table G-13. Profile 16: Description for Unit 4, 41BR253 ................................................................................ 121

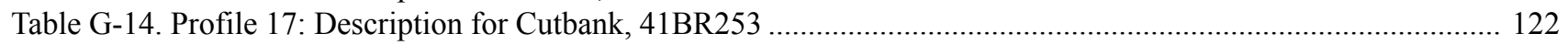

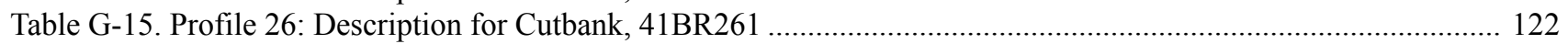

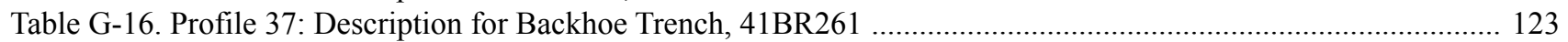

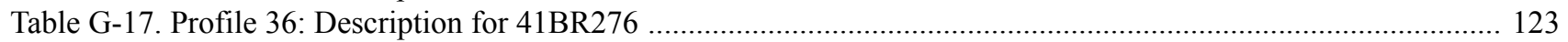

Table G-18. Profile 7: Description for Cutbank near 41BR415 .......................................................................... 124

Table G-19. Profile 8: Description for Unit 2, 41BR415 ................................................................................ 125

Table G-20. Profile 38: Description for Backhoe Trench, 41BR415 …................................................................... 125

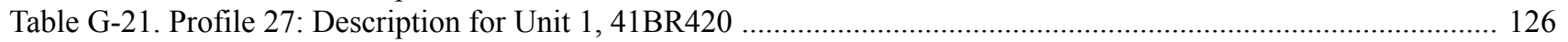

Table G-22. Profile 29: Description for Cutbank north of 41BR420 ....................................................................... 126

Table G-23. Profile 33: Description for Unit 2, 41BR433 …….............................................................................. 127

Table G-24. Profile 34: Description for Unit 1 (west wall), 41BR433 (profile in recent pit fill) ................................... 127

Table G-25. Profile 35: Description for Unit 4 (east wall), 41BR433 …................................................................... 128

Table G-26. Profile 6: Description for Trench 4 (within the midden near basal feature), 41BR441 ............................. 129

Table G-27. Profile 5: Description for Trench 4 (outside of the midden), 41BR441 .................................................. 129

Table G-28. Profile 1: Description for Trench 1 (on the midden edge), 41BR474 …............................................. 131

Table G-29. Profile 2: Description for Trench 1 (near center of midden), 41BR474 .................................................... 131

Table G-30. Profile 3: Description for Trench 2, across the stream from 41BR474 …................................................ 132

Table G-31. Profile 4: Description for Trench 3 in midden at 41BR474 ................................................................ 132

Table G-32. Profile 21: Description for Unit 1 (edge of north wall), 41BR480 ....................................................... 133

Table G-33. Profile 23: Description for Unit 3 (north wall), 41BR480 ................................................................. 134

Table G-34. Profile 24: Description for Cutbank north of 41BR480 ..................................................................... 134

Table G-35. Profile 30: Description for Unit 2, 41BR492 ……............................................................................. 135

Table G-36. Profile 31: Description for Unit 5, 41BR492 ……............................................................................ 135

Table G-37. Profile 32: Description for Unit 4, 41BR492 …............................................................................. 135

Table G-38. Profile 40: Description for Backhoe Trench adjacent to Unit 4 (on south side), 41BR492 ....................... 136

Table H-1. Magnetic Sediment Susceptibility Data for a Variety of Substances ........................................................... 141

Table H-2. Presence/absence of Cultural Material and Mass Specific Susceptibility Scores for 41BR473 ................... 141

Table H-3. Sediment Susceptibility Data for 41BR492, Unit 3 ........................................................................... 142

Table J-1. Diagnostic Artifacts (presence/absence) from Burned Rock Middens used in Figure 7-6 (volume 1) ............ 148 

Appendix A

\section{Radiocarbon Results}


Dr. Raymond Mauldin

Report Date: 9/10/01

University of Texas at San Antonio

Material Received: 7/31/01

\begin{tabular}{|c|c|c|c|}
\hline Sample Data & $\begin{array}{c}\text { Measured } \\
\text { Radiocarbon Age }\end{array}$ & $\begin{array}{c}13 \mathrm{C} / 12 \mathrm{C} \\
\text { Ratio }\end{array}$ & $\begin{array}{c}\text { Conventional } \\
\text { Radiocarbon Age }\left(^{*}\right)\end{array}$ \\
\hline $\begin{array}{l}\text { Beta - } 157965 \\
\text { SAMPLE : QQ48-12\#13 } \\
\text { ANALYSIS : AMS-Standard c } \\
\text { MATERIAL/PRETREATMEI } \\
2 \text { SIGMA CALIBRATION : }\end{array}$ & $\begin{array}{l}1000+/-40 \mathrm{BP} \\
\text { material): acid/alkali/c } \\
980 \text { to } 1060(\mathrm{Cal} \mathrm{BP} 9\end{array}$ & $\begin{array}{c}-24.8 \mathrm{o} / \mathrm{oo} \\
\mathrm{ND} \text { Cal AD } 1\end{array}$ & $1000+/-40 \mathrm{BP}$ \\
\hline $\begin{array}{l}\text { Beta - } 157966 \\
\text { SAMPLE : QQ48-12\#24 } \\
\text { ANALYSIS : AMS-Standard c } \\
\text { MATERIAL/PRETREATMEI } \\
2 \text { SIGMA CALIBRATION : }\end{array}$ & $\begin{array}{l}1320+/-40 \mathrm{BP} \\
660 \text { to } 810(\mathrm{Cal} \mathrm{BP} 12\end{array}$ & $\begin{array}{l}-27.4 \mathrm{o} / \mathrm{oo} \\
\text { AND Cal AD }\end{array}$ & $\begin{array}{l}1280+/-40 \mathrm{BP} \\
\text { BP } 1110 \text { to } 1100)\end{array}$ \\
\hline $\begin{array}{l}\text { Beta - } 157967 \\
\text { SAMPLE : QQ48-12\#32 } \\
\text { ANALYSIS : AMS-Standard c } \\
\text { MATERIAL/PRETREATMEN } \\
2 \text { SIGMA CALIBRATION : }\end{array}$ & $\begin{array}{l}1900+/-40 \text { BP } \\
11): \text { acid/alkali/acid } \\
30 \text { to } 220(\mathrm{Cal} \text { BP } 192\end{array}$ & $-24.7 \mathrm{o} / \mathrm{oo}$ & $1900+/-40 \mathrm{BP}$ \\
\hline $\begin{array}{l}\text { Beta - } 157968 \\
\text { SAMPLE : QQ48-19\#8 } \\
\text { ANALYSIS : AMS-Standard c } \\
\text { MATERIAL/PRETREATMEN } \\
2 \text { SIGMA CALIBRATION : }\end{array}$ & $\begin{array}{l}1210+/-40 \text { BP } \\
770 \text { to } 980(\mathrm{Cal} \mathrm{BP} 11\end{array}$ & $-27.5 \mathrm{o} / \mathrm{oo}$ & $1170+/-40 \mathrm{BP}$ \\
\hline $\begin{array}{l}\text { Beta - } 157969 \\
\text { SAMPLE : QQ48-22\#1 } \\
\text { ANALYSIS : AMS-Standard c } \\
\text { MATERIAL/PRETREATMEN } \\
2 \text { SIGMA CALIBRATION : }\end{array}$ & $\begin{array}{l}1600+/-40 \mathrm{BP} \\
390 \text { to } 550(\mathrm{Cal} \mathrm{BP} 15\end{array}$ & $-25.3 \mathrm{o} / \mathrm{oo}$ & $1600+/-40 \mathrm{BP}$ \\
\hline $\begin{array}{l}\text { Beta - } 157970 \\
\text { SAMPLE : QQ49-1\#10 } \\
\text { ANALYSIS : AMS-Standard c } \\
\text { MATERIAL/PRETREATMEN } \\
2 \text { SIGMA CALIBRATION : }\end{array}$ & $\begin{array}{l}400+/-40 \mathrm{BP} \\
1440 \text { to } 1640 \text { (Cal BP }\end{array}$ & $-27.1 \mathrm{o} / \mathrm{oo}$ & $370+/-40 \mathrm{BP}$ \\
\hline
\end{tabular}


Dr. Raymond Mauldin

Report Date: 10/3/01

University of Texas at San Antonio

Material Received: 8/24/01

\begin{tabular}{|c|c|c|c|}
\hline Sample Data & $\begin{array}{c}\text { Measured } \\
\text { Radiocarbon Age }\end{array}$ & $\begin{array}{c}13 \mathrm{C} / 12 \mathrm{C} \\
\text { Ratio }\end{array}$ & $\begin{array}{c}\text { Conventional } \\
\text { Radiocarbon Age }\left(^{*}\right)\end{array}$ \\
\hline $\begin{array}{l}\text { Beta - } 158818 \\
\text { SAMPLE : } 87-7-2.5 \\
\text { ANALYSIS : AMS-Standard c } \\
\text { MATERIAL/PRETREATMEI } \\
2 \text { SIGMA CALIBRATION : }\end{array}$ & $\begin{array}{l}1310+/-40 \mathrm{BP} \\
660 \text { to } 790 \text { (Cal BP } 12\end{array}$ & $-26.2 \mathrm{o} / \mathrm{oo}$ & $1290+/-40 \mathrm{BP}$ \\
\hline $\begin{array}{l}\text { Beta - } 158819 \\
\text { SAMPLE : } 87-2-7 \\
\text { ANALYSIS : AMS-Standard c } \\
\text { MATERIAL/PRETREATMEI } \\
2 \text { SIGMA CALIBRATION : }\end{array}$ & $\begin{array}{l}1180+/-40 \mathrm{BP} \\
780 \text { to } 980 \text { (Cal BP } 11\end{array}$ & $-26.4 \mathrm{o} / \mathrm{oo}$ & $1160+/-40 \mathrm{BP}$ \\
\hline $\begin{array}{l}\text { Beta - } 158820 \\
\text { SAMPLE : } 87-2-4 \\
\text { ANALYSIS : AMS-Standard c } \\
\text { MATERIAL/PRETREATMEI } \\
2 \text { SIGMA CALIBRATION : }\end{array}$ & $\begin{array}{l}890+/-40 \mathrm{BP} \\
\text { material): acid/alkali/c } \\
1040 \text { to } 1260(\mathrm{Cal} \mathrm{BP}\end{array}$ & $-26.6 \mathrm{o} / \mathrm{oo}$ & $860+/-40 \mathrm{BP}$ \\
\hline $\begin{array}{l}\text { Beta - } 158821 \\
\text { SAMPLE : } 65-7-6 \\
\text { ANALYSIS : AMS-Standard c } \\
\text { MATERIAL/PRETREATMEI } \\
2 \text { SIGMA CALIBRATION : }\end{array}$ & $\begin{array}{l}1160+/-40 \mathrm{BP} \\
780 \text { to } 980 \text { (Cal BP } 11\end{array}$ & $-25.3 \mathrm{o} / \mathrm{oo}$ & $1160+/-40 \mathrm{BP}$ \\
\hline $\begin{array}{l}\text { Beta - } 158822 \\
\text { SAMPLE : } 65-7-5 \\
\text { ANALYSIS : AMS-Standard c } \\
\text { MATERIAL/PRETREATMEI } \\
2 \text { SIGMA CALIBRATION : }\end{array}$ & $\begin{array}{l}1150+/-40 \mathrm{BP} \\
\text { material): acid/alkali/c } \\
790 \text { to } 990 \text { (Cal BP } 11\end{array}$ & $-25.7 \mathrm{o} / \mathrm{oo}$ & $1140+/-40 \mathrm{BP}$ \\
\hline
\end{tabular}




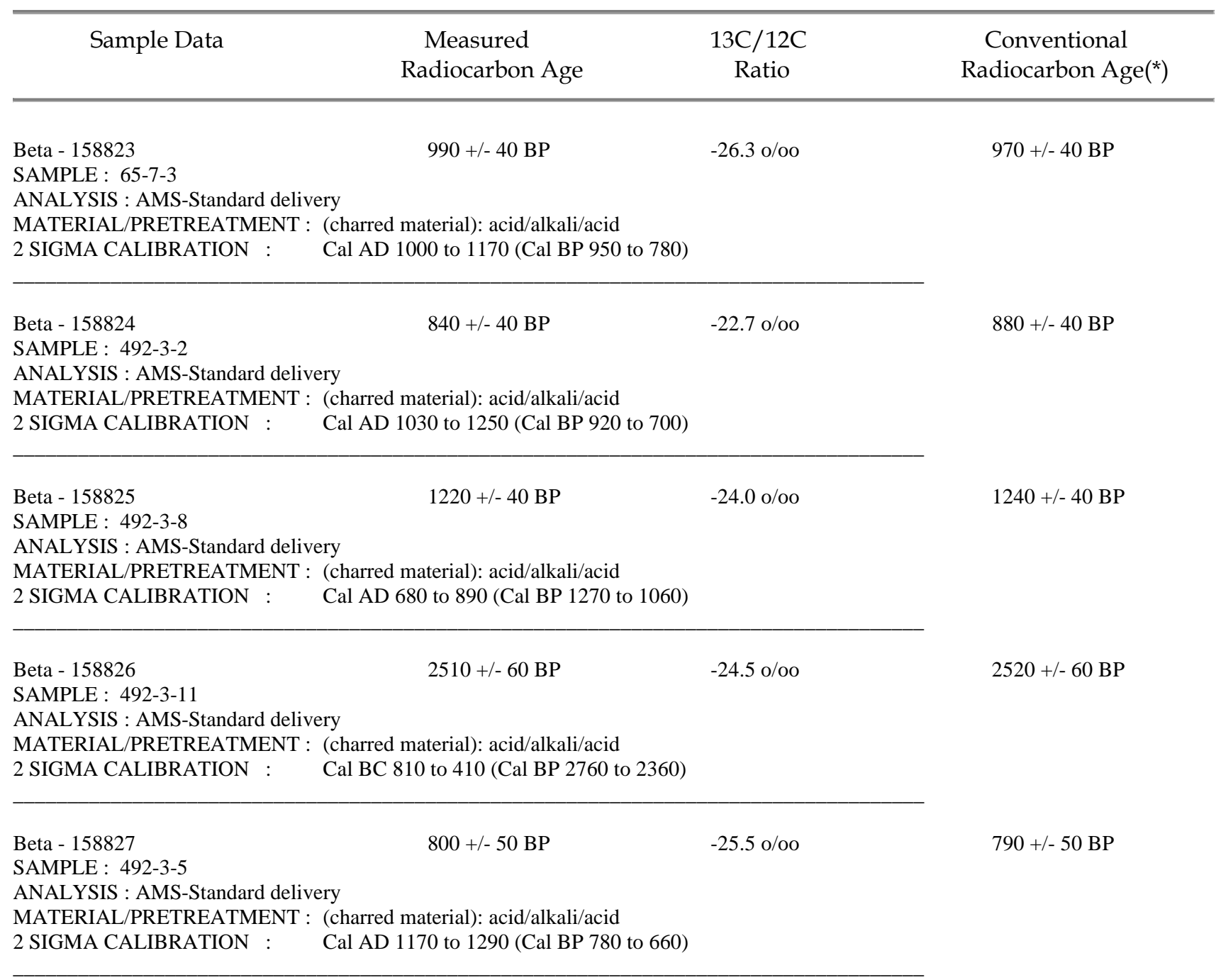


Dr. Raymond Mauldin

University of Texas at San Antonio
Report Date: 10/23/01

Material Received: 9/14/01

\begin{tabular}{|c|c|c|c|}
\hline Sample Data & $\begin{array}{c}\text { Measured } \\
\text { Radiocarbon Age }\end{array}$ & $\begin{array}{c}13 \mathrm{C} / 12 \mathrm{C} \\
\text { Ratio }\end{array}$ & $\begin{array}{c}\text { Conventional } \\
\text { Radiocarbon Age }\left(^{*}\right)\end{array}$ \\
\hline $\begin{array}{l}\text { Beta - } 159517 \\
\text { SAMPLE : } 420-3-2 \\
\text { ANALYSIS : AMS-Standard delivery } \\
\text { MATERIAL/PRETREATMENT : (c } \\
2 \text { SIGMA CALIBRATION : }\end{array}$ & $\begin{array}{l}\qquad 930+/-70 \text { BP } \\
\text { ery } \\
\text { (charred material): acid/alkali/acid } \\
\text { Cal AD } 990 \text { to } 1260 \text { (Cal BP } 960 \text { to } 690 \text { ) }\end{array}$ & $-25.1 \mathrm{o} / \mathrm{oo}$ & $930+/-70$ BP \\
\hline $\begin{array}{l}\text { Beta - } 159518 \\
\text { SAMPLE : 420-3-7 } \\
\text { ANALYSIS : AMS-Standard delivery } \\
\text { MATERIAL/PRETREATMENT : (c } \\
\text { 2 SIGMA CALIBRATION : }\end{array}$ & $\begin{array}{l}\qquad 1530+/ \text { - } 40 \text { BP } \\
\text { ery } \\
\text { (charred material): acid/alkali/acid } \\
\text { Cal AD } 450 \text { to } 640 \text { (Cal BP } 1500 \text { to } 1310)\end{array}$ & $-26.8 \mathrm{o} / \mathrm{oo}$ & $1500+/-40 \mathrm{BP}$ \\
\hline $\begin{array}{l}\text { Beta - } 159519 \\
\text { SAMPLE : 433-1-6 } \\
\text { ANALYSIS : AMS-Standard delivery } \\
\text { MATERIAL/PRETREATMENT : (c } \\
2 \text { SIGMA CALIBRATION : }\end{array}$ & $\begin{array}{l}\qquad 910+/ \text { - } 50 \text { BP } \\
\text { ery } \\
\text { (charred material): acid/alkali/acid } \\
\text { Cal AD } 1020 \text { to } 1250 \text { (Cal BP } 930 \text { to } 700)\end{array}$ & $-25.9 \mathrm{o} / \mathrm{oo}$ & $900+/-50 \mathrm{BP}$ \\
\hline $\begin{array}{l}\text { Beta - } 159520 \\
\text { SAMPLE : 441-1-5 } \\
\text { ANALYSIS : AMS-Standard delivery } \\
\text { MATERIAL/PRETREATMENT : (c } \\
2 \text { SIGMA CALIBRATION : }\end{array}$ & $\begin{array}{l}\qquad 1140+/ \text { - } 60 \text { BP } \\
\text { ery } \\
\text { (charred material): acid/alkali/acid } \\
\text { Cal AD } 690 \text { to } 990 \text { (Cal BP } 1260 \text { to } 960)\end{array}$ & $-22.2 \mathrm{o} / \mathrm{oo}$ & $1190+/-60 \mathrm{BP}$ \\
\hline $\begin{array}{l}\text { Beta - } 159521 \\
\text { SAMPLE : 474-1-3A } \\
\text { ANALYSIS : AMS-Standard delivery } \\
\text { MATERIAL/PRETREATMENT : (c } \\
\text { 2 SIGMA CALIBRATION : }\end{array}$ & $\begin{array}{l}\qquad 960+/ \text { - } 40 \text { BP } \\
\text { ery } \\
\text { (charred material): acid/alkali/acid } \\
\text { Cal AD } 1000 \text { to } 1180 \text { (Cal BP } 950 \text { to } 780)\end{array}$ & $-24.9 \mathrm{o} / \mathrm{oo}$ & $960+/-40$ BP \\
\hline $\begin{array}{l}\text { Beta - } 159522 \\
\text { SAMPLE : 474-2-2 } \\
\text { ANALYSIS : AMS-Standard delivery } \\
\text { MATERIAL/PRETREATMENT : (c } \\
\text { 2 SIGMA CALIBRATION : }\end{array}$ & $\begin{array}{l}\qquad 910+/ \text { - } 40 \text { BP } \\
\text { ry } \\
\text { (charred material): acid/alkali/acid } \\
\text { Cal AD } 1020 \text { to } 1210 \text { (Cal BP } 930 \text { to } 740)\end{array}$ & $-24.3 \mathrm{o} / \mathrm{oo}$ & $920+/-40$ BP \\
\hline
\end{tabular}


Dr. Raymond Mauldin

Report Date: 11/21/01

University of Texas at San Antonio

Material Received: 10/19/01

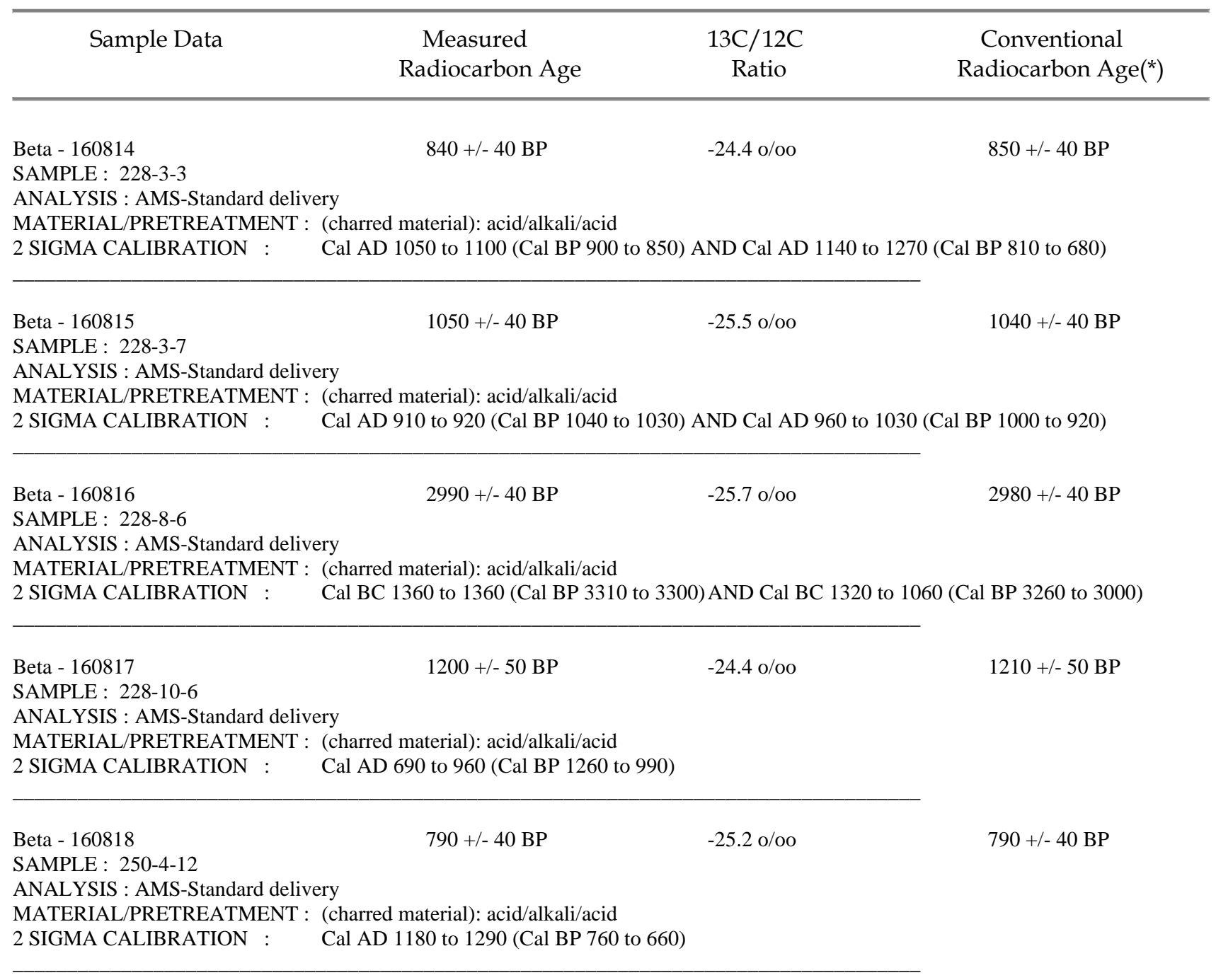




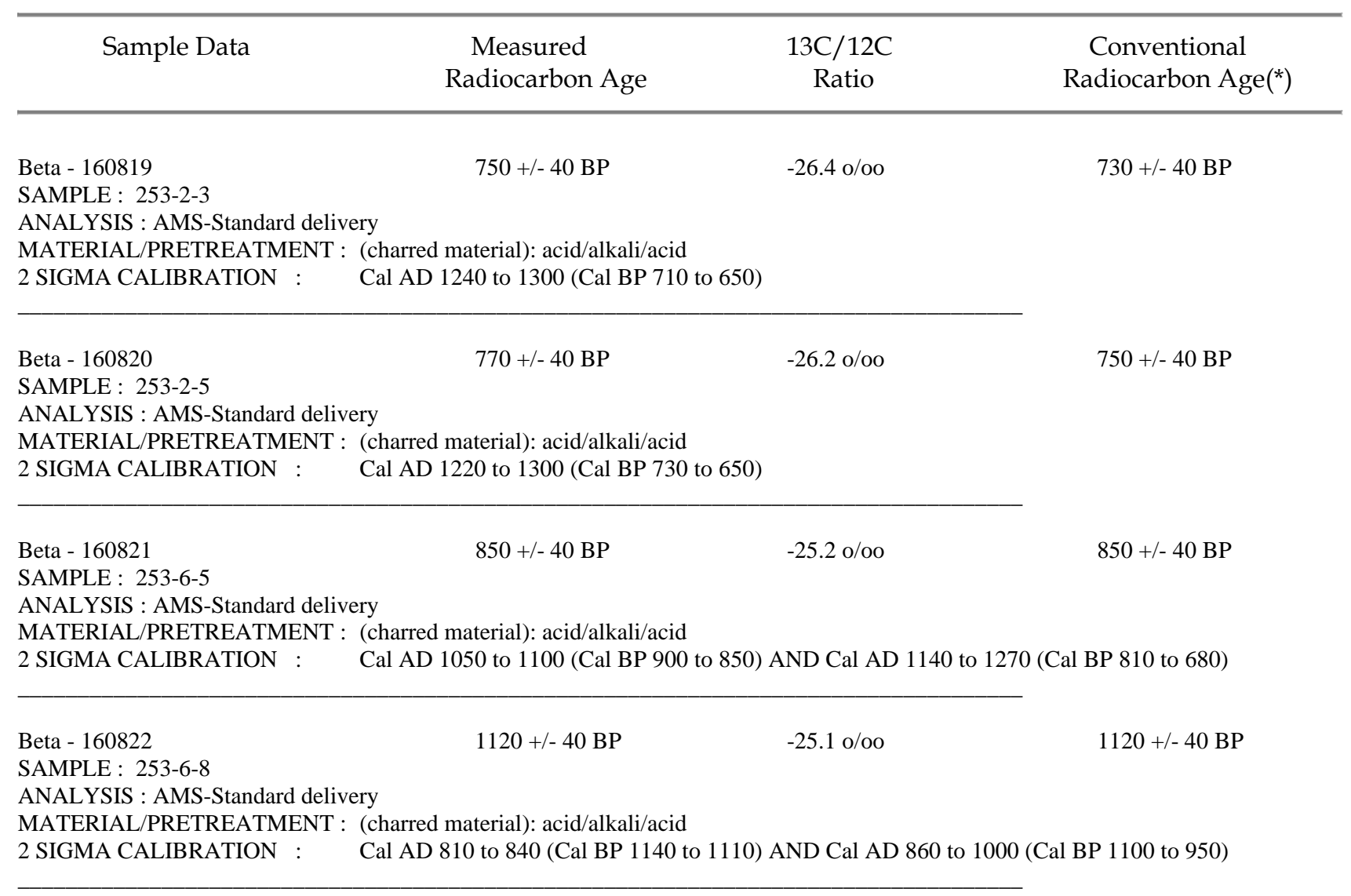


Dr. Raymond Mauldin

Report Date: 12/20/01

University of Texas at San Antonio

Material Received: 11/21/01

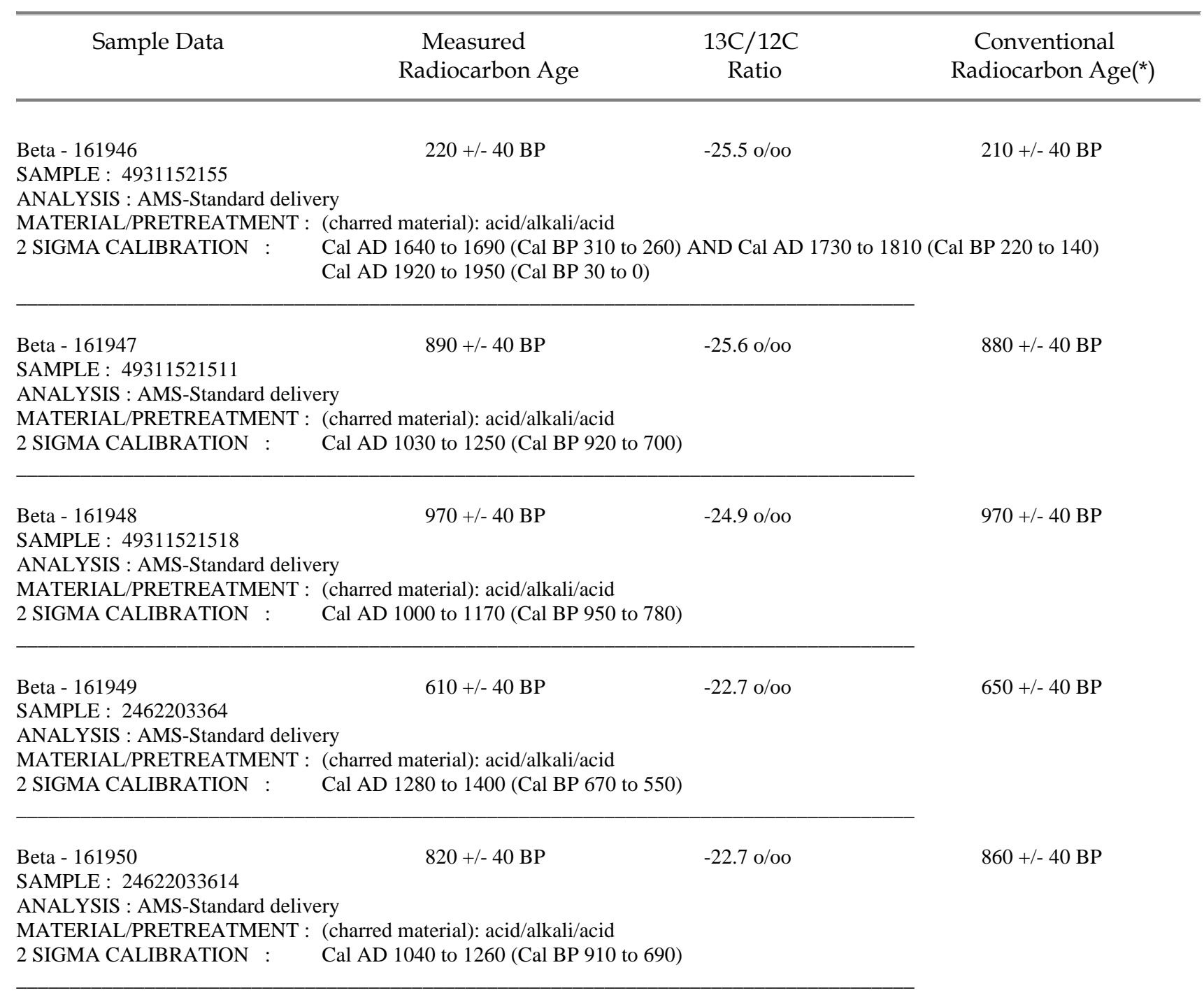




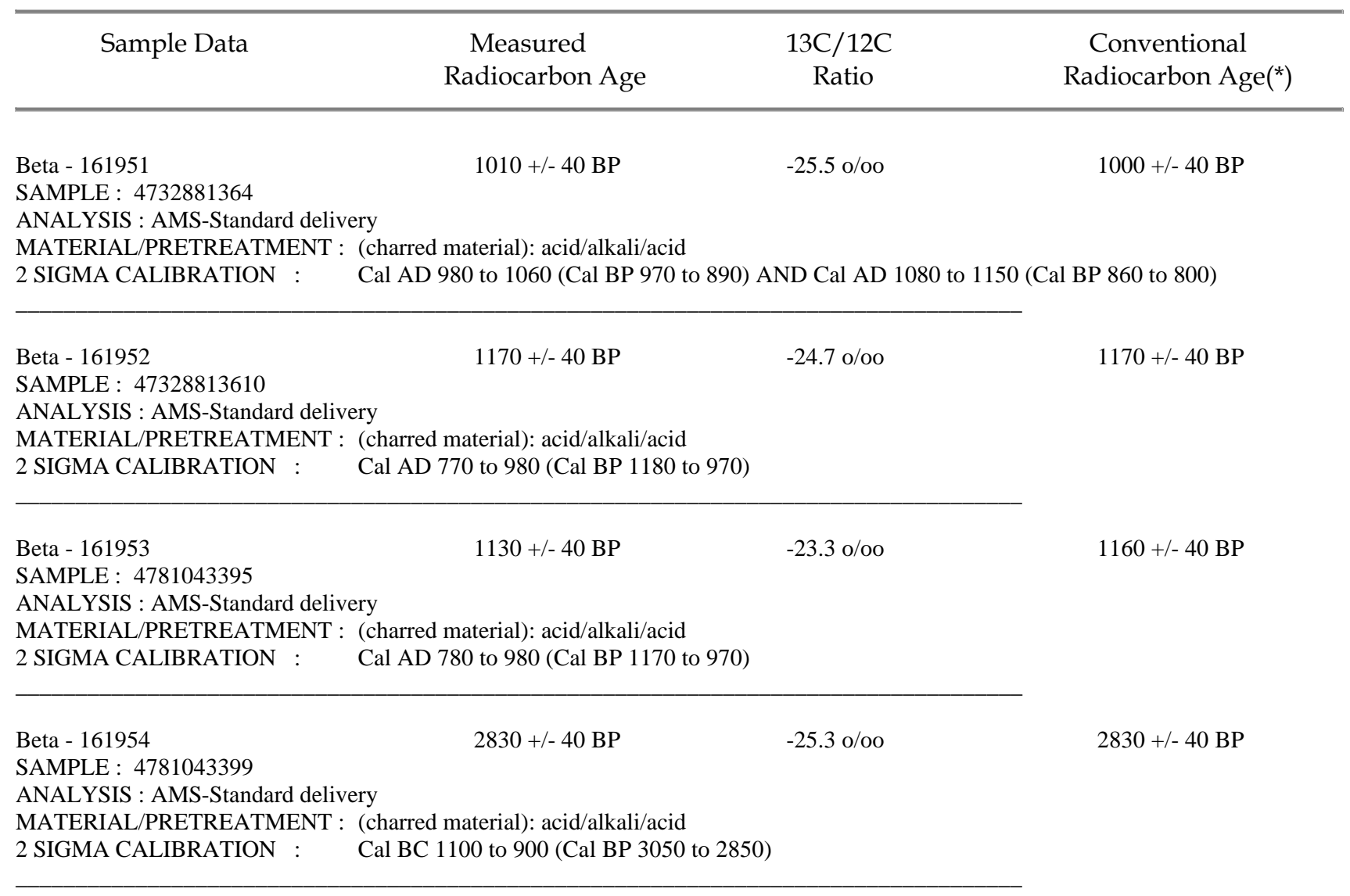




\section{CALIBRATION OF RADIOCARBON AGE TO CALENDAR YEARS}

(Variables: C13/C12=-24.8:1ab. mult=1)

Laboratory number: Beta-157965

Conventional radiocarbon age: $1000 \pm 40 \mathrm{BP}$

2 Sigm a calibrated results: Cal AD 980 to 1060 (Cal BP 970 to 890 ) and

(95\% probability) Cal AD 1080 to 1150 (Cal BP 860 to 800)

Intercept data

Intercept of radiocarbon age

with calibration curve:

Cal AD 1020 (Cal BP 930)

1 Sigm a calibrated result: (68\% probability)

Cal AD 1000 to 1030 (Cal BP 950 to 920)

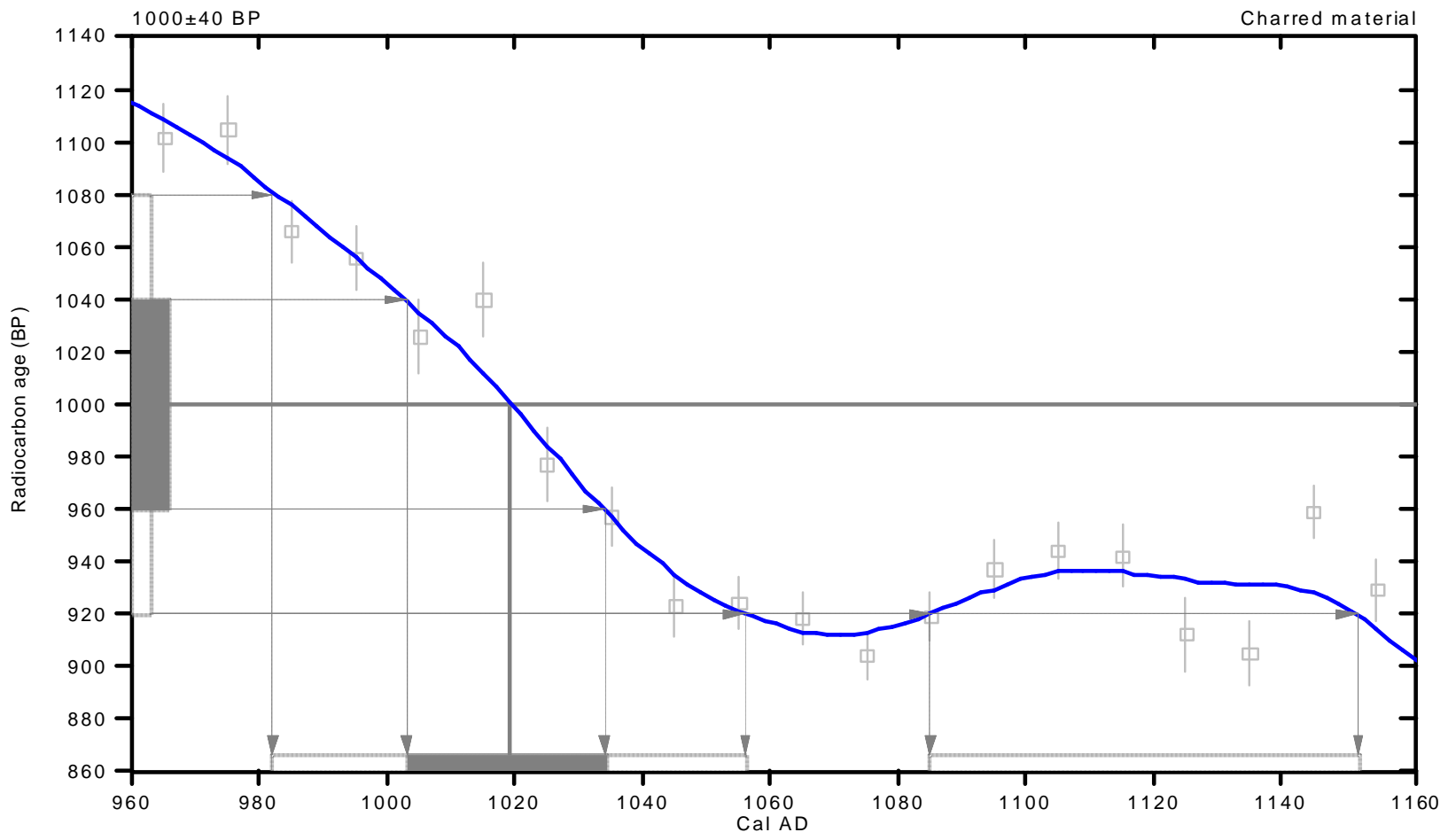

References:

Database used

Calibration Database

Editorial Com ment

Stuiver, M., van der Plicht, H., 1998, Radioca rbon 40(3), pxii-xiii

IN TCA L98 Radiocarbon Age Calibration

Stuiver, M., et. al., 1998, Ra diocarbon 40(3), p1041-1083

Mathe matics

A Simplified Approach to Calibrating C14 Dates

Talma, A.S., Vogel, J. C., 1993, Radiocarbon 35(2), p317-322

\section{Beta Analytic Inc.}

4985 SW 74 Court, Miami, Florida 33155 USA $\cdot$ Tel: (305) $6675167 \cdot$ Fax: (305) $6630964 \cdot$ E-Mail: beta@ radiocarbon.com 


\section{CALIBRATION OF RADIOCARBON AGE TO CALENDAR YEARS}

(Variables: C13/C 12=-27.4:1ab. mult=1)

Laboratory number: Beta-157966

Conventional radiocarbon age: $1280 \pm 40 \mathrm{BP}$

2 Sigm a calibrated results: Cal AD 660 to 810 (Cal BP 1280 to 1140) and (95\% probability) Cal AD 840 to 860 (Cal BP 1110 to 1100)

Intercept data

Intercept of radiocarbon age

with calibration curve:

Cal AD $710($ Cal B P 1240)

1 Sigm a calibrated result: (68\% probability)

Cal AD 680 to 780 (Cal BP 1270 to 1170 )

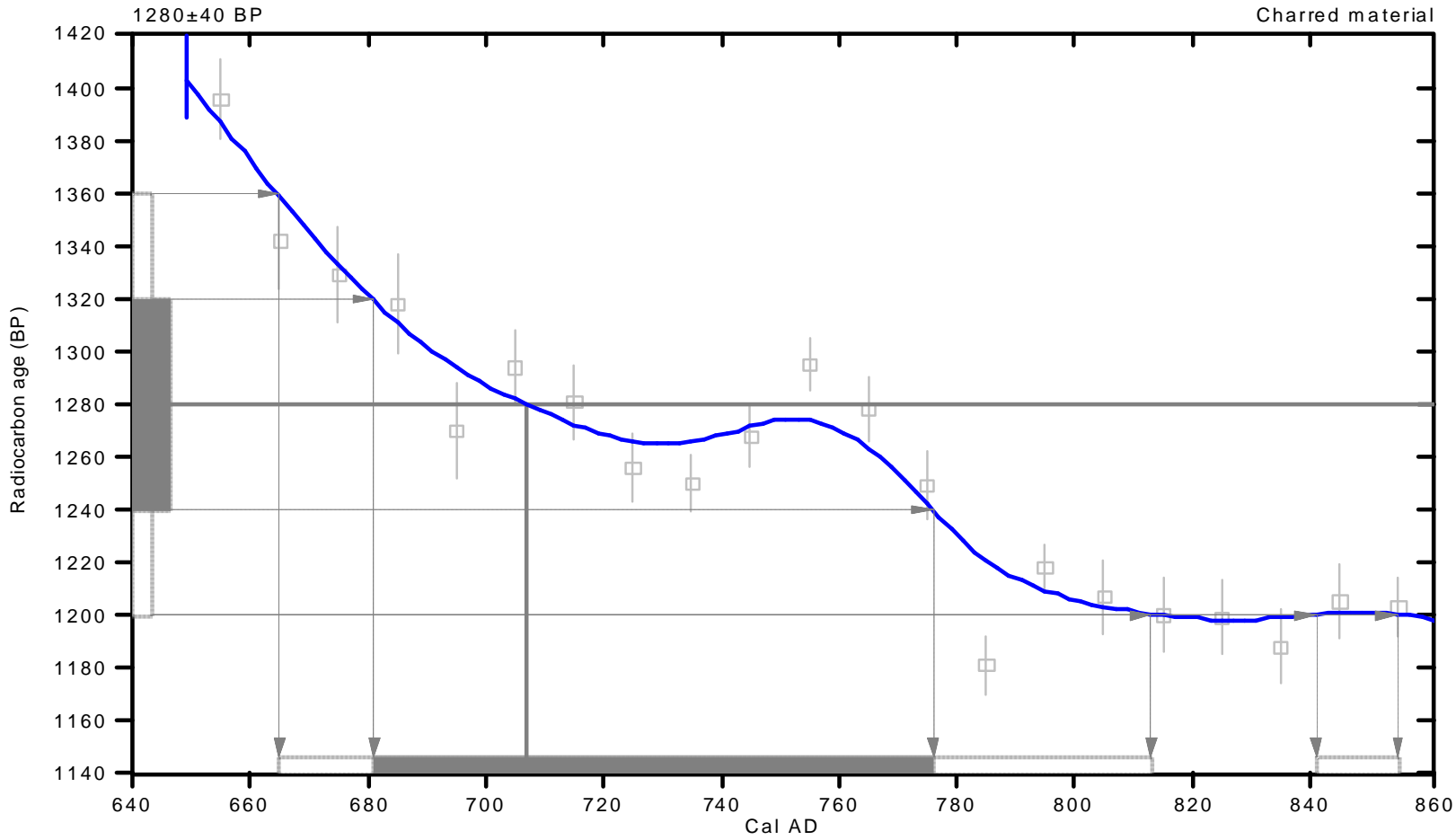

References:

Database used

Calibration Database

Editorial Com ment

Stuiver, M., van der Plicht, H., 1998, Radioca rbon 40(3), pxii-xiii

INTCAL98 Radiocarbon Age Calibration

Stuiver, M., et. al., 1998, Radiocarbon 40(3), p1041-1083

Math ematic

A Simplified Approach to Calibrating C14 Dates Talma, A. S.. Vogel, J. C.., 1993, Radiocarbon 35(2), p317-322

\section{Beta Analytic Inc.}

4985 SW 74 Court, Miami, Florida 33155 USA -Tel: (305) $6675167 \cdot$ Fax: (305) $6630964 \cdot$ E-Mail: beta@ radiocarbon.com 


\section{CALIBRATION OF RADIOCARBON AGE TO CALENDAR YEARS}

(V ariables: C 13/C12=-24.7:1ab. mult=1)

Laboratory number: Beta-157967

Conventional radiocarbon age: $1900 \pm 40$ BP

2 Sigm a calibrated result: Cal AD 30 to 220 (Cal BP 1920 to 1730)

(95\% probability)

Intercept data

Intercept of radiocarbon age

with calibration curve: Cal AD 100 (Cal BP 1860)

1 Sigma calibrated result: Cal AD 70 to 130 (Cal BP 1880 to 1820)

( $68 \%$ probability)

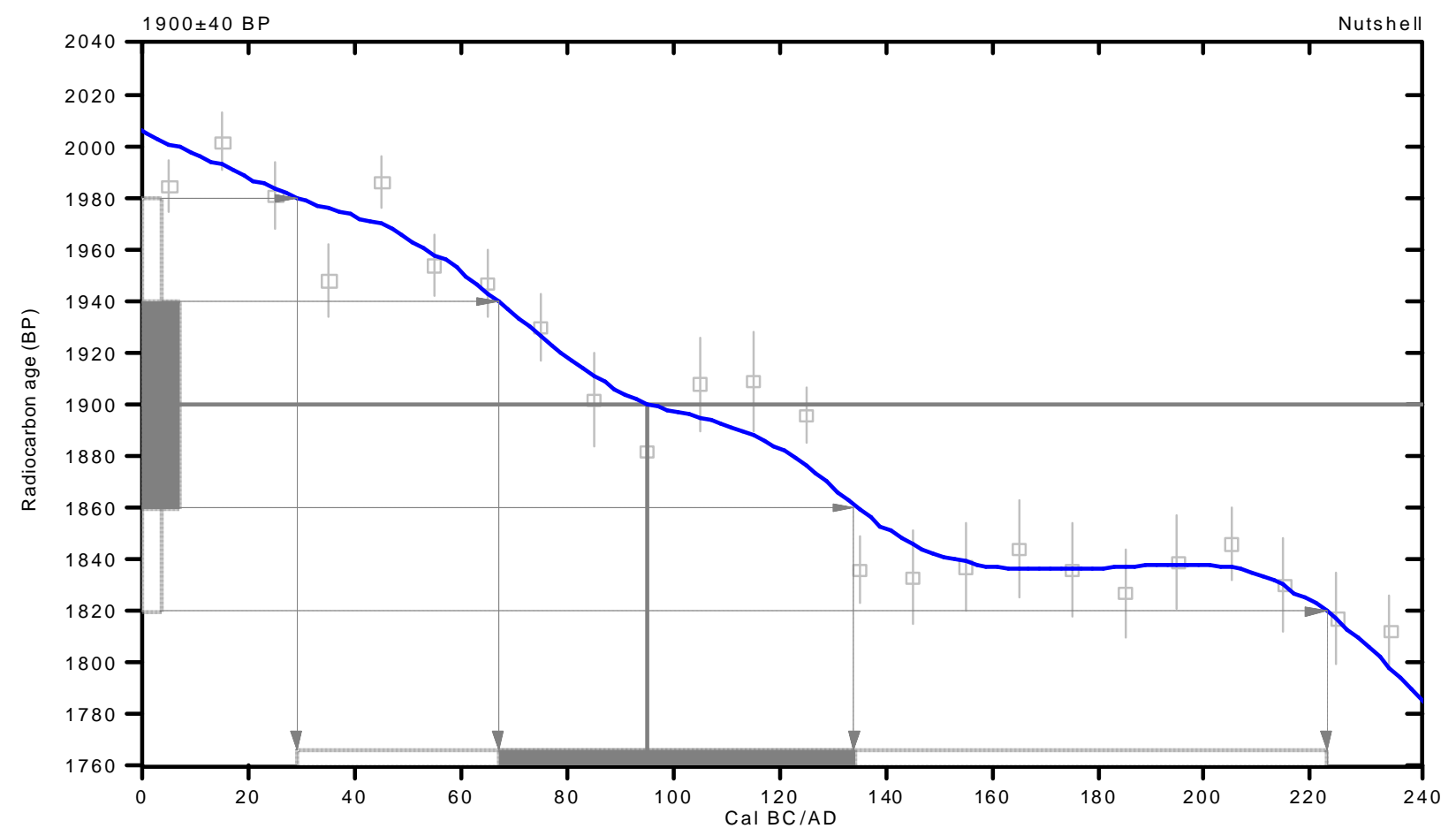

References:

Database used

Calibration Database

Editorial Com ment

Stuiver, M., van der Plicht, H., 1998, Radioca rbon 40(3), pxii-xiii

INTCAL98 Radiocarbon Age Calibration

Stuiver, M., et. al., 1998, Radiocarbon 40(3), p1041-1083

Mathe matics

A Simplified Approach to Calibrating C14 Dates

Talma, A. S., Vogel, J. C., 1993, Radiocarbon $35(2)$, p317-322

\section{Beta Analytic Inc.}

4985SW74 Court, Miami, Florida 33155 USA -Tel: (305)6675167•Fax:(305)6630964 •E-Mail: beta@radiocarbon.com 


\section{CALIBRATION OF RADIOCARBON AGE TO CALENDAR YEARS}

(V ariables: C $13 / \mathrm{C} 12=-27.5: 1 \mathrm{ab} . \mathrm{mult}=1$ )

Laboratory number: Beta-157968

Conventional radiocarbon age: $1170 \pm 40 \mathrm{BP}$

2 Sigm a calibrated result: Cal AD 770 to 980 (Cal BP 1180 to 970) (95\% probability)

Intercept data

Intercept of radiocarbon age

with calibration curve: Cal AD 880 (Cal BP 1070)

1 Sigm a calibrated result: Cal AD 790 to 900 (Cal BP 1160 to 1050) (68\% probability)

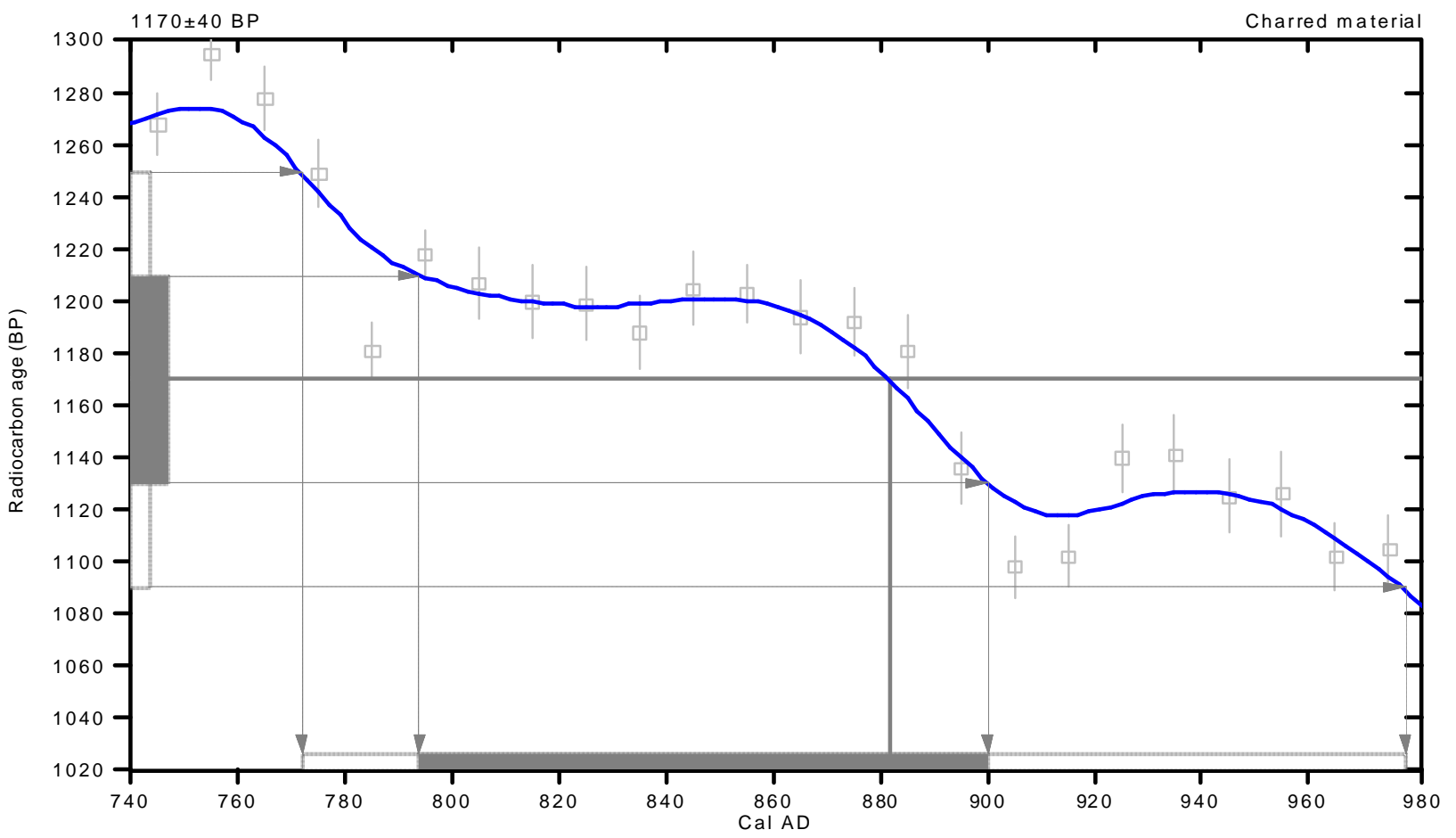

References:

Da tabase used

Calibration Database

Editorial Com ment

Stuiver, M., van der Plicht, H., 1998, Ra dioca rbon 40(3), pxii-xiii

IN TCA L98 Radiocarbon Age Calibration

Stuiver, M., et. al., 1998, Radiocarbon 40(3), p1041-1083

$M$ ath e matics

A Simplified Approach to Calibrating C14 Dates

Talma, A. S., Vogel, J. C., 1993, Radiocarbon 35(2), p317-322

\section{Beta Analytic Inc.}

4985 SW 74 Court, Miami, Florida 33155 USA $\cdot$ Tel: (305) $6675167 \cdot$ Fax: (305) $6630964 \cdot$ E-Mail: beta@ radiocarbon.com 


\section{CALIBRATION OF RADIOCARBON AGE TO CALENDAR YEARS}

(Variables: C $13 / \mathrm{C} 12=-25.3: 1 \mathrm{ab} . \mathrm{mult}=1$ )

Laboratory number: Beta-157969

Conventional radiocarbon age: $1600 \pm 40 \mathrm{BP}$

2 Sigm a calibrated result: Cal AD 390 to 550 (Cal BP 1560 to 1400)

(95\% probability)

Intercept data

Intercept of radiocarbon age

with calibration curve: Cal AD 430 (Cal B P 1520)

1 Sigma calibrated result: Cal AD 410 to 530 (Cal BP 1540 to 1420)

( $68 \%$ probability)

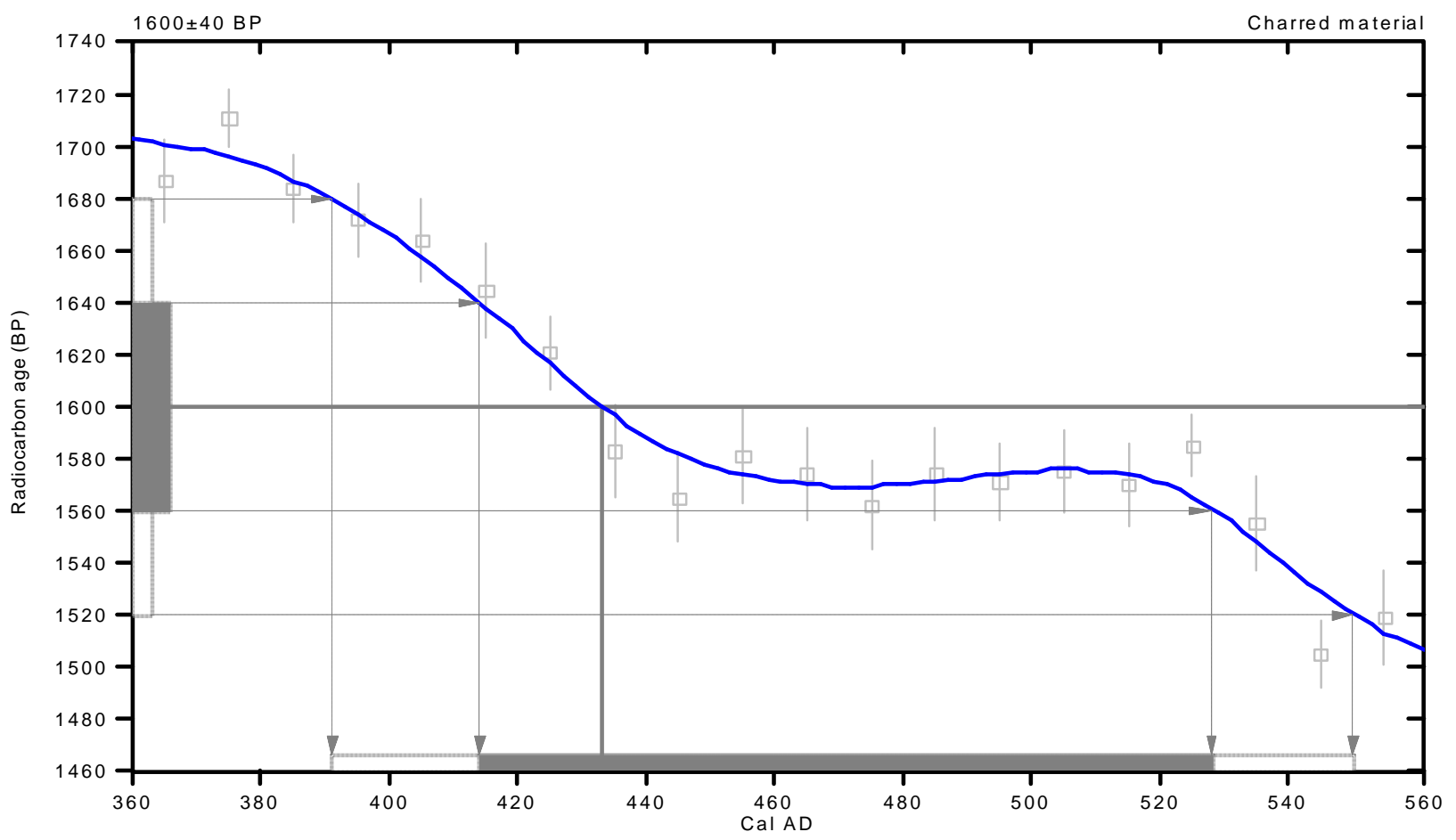

References:

Database used

Calibration Database

Editorial Com ment

Stuiver, M., van der Plicht, H., 1998, Radioca rbon 40(3), pxii-xiii

INTCAL98 Radiocarbon Age Calibration

Stuiver, M., et. al., 1998, Radiocarbon 40(3), p1041-1083

$M$ ath ematics

A Simplified Approach to Calibrating C14 Dates

Talma, A. S., Vogel, J. C., 1993, Radiocarbon $35(2)$, p317-322

\section{Beta Analytic Inc.}

4985 SW 74 Court, Miami, Florida 33155 USA -Tel: (305)6675167•Fax:(305)6630964 •E-Mail: beta@radiocarbon.com 


\section{CALIBRATION OF RADIOCARBON AGE TO CALENDAR YEARS}

(V ariables: C $13 / \mathrm{C} 12=-27.1: 1 \mathrm{ab} . \mathrm{mult}=1$ )

Laboratory number: Beta-157970

Conventional radiocarbon age: $370 \pm 40 \mathrm{BP}$

2 Sigm a calibrated result: Cal AD 1440 to 1640 (Cal BP 510 to 310 )

(95\% probability)

Intercept data

Intercept of radiocarbon age

with calibration curve: Cal AD 1490 (Cal BP 460)

1 Sigm a calibrated results: Cal AD 1460 to 1520 (Cal BP 490 to 430) and

(68\% probability) Cal AD 1580 to 1630 (Cal B P 380 to 320)

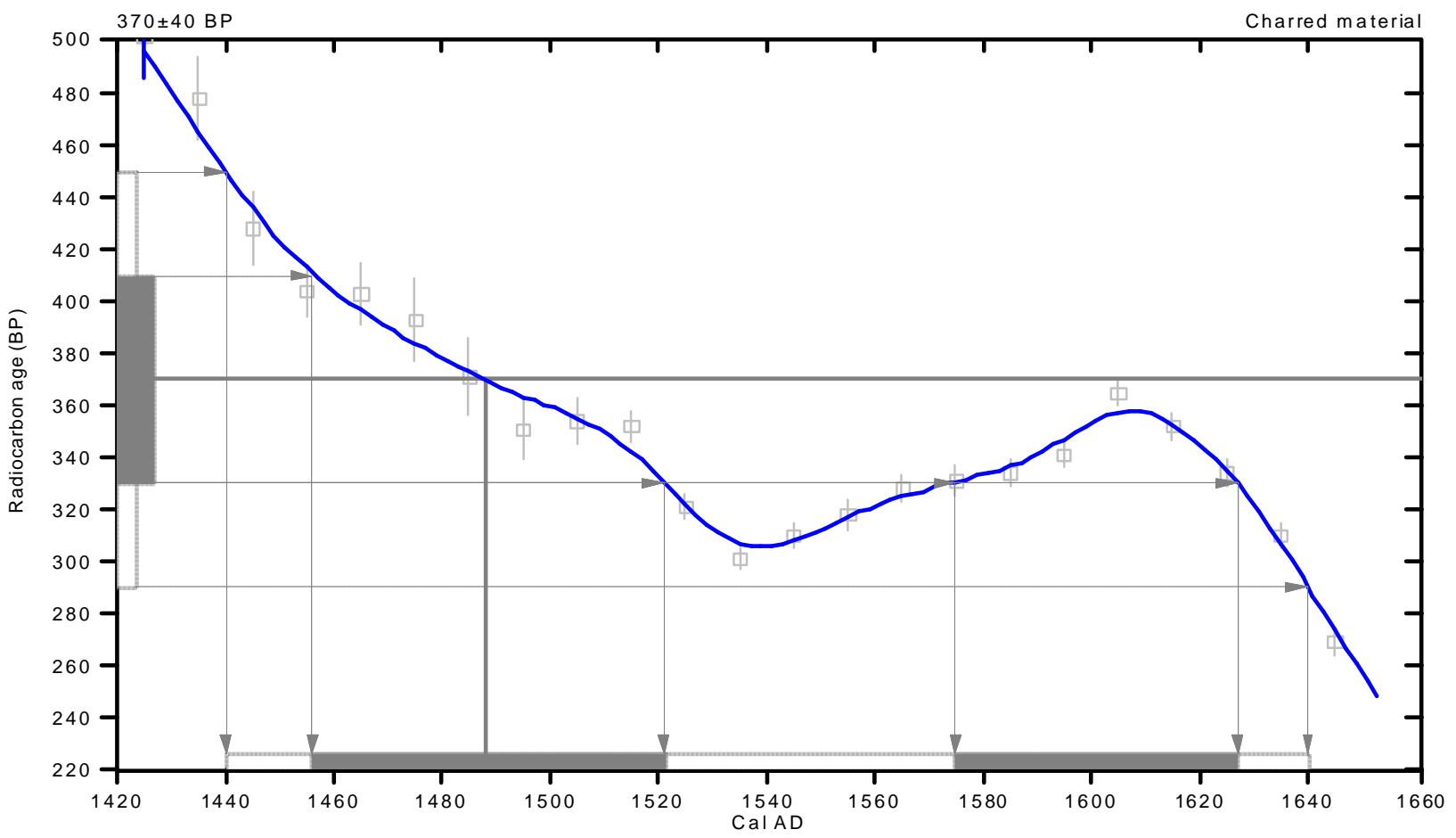

References:

Database used

Calibration Database

Editorial Com ment

Stuiver, M., van der Plicht, H., 1998, Ra dioca rbon 40(3), pxii-xiii

INTCAL98 Radiocarbon Age Calibration

Stuiver, M., et. al., 1998, Radiocarbon 40(3), p1041-1083

$M$ ath e matics

A Simplified Approach to Calibrating C14 Dates

Talma, A. S., Vogel, J. C., 1993, Radiocarbon 35(2), p317-322

\section{Beta Analytic Inc.}

4985 SW 74 Court, Miami, Florida 33155 USA • Tel: (305) $6675167 \cdot$ Fax: (305) $6630964 \cdot$ E-Mail: beta @ radiocarbon.com 


\section{CALIBRATION OF RADIOCARBON AGE TO CALENDAR YEARS}

(V ariables: C $13 / \mathrm{C} 12=-26.2: 1 \mathrm{ab} . \mathrm{mult}=1$ )

Laboratory number: Beta-158818

Conventional radiocarbon age: $1290 \pm 40$ BP

2 Sigm a calibrated result: Cal AD 660 to 790 (Cal BP 1290 to 1160 )

(95\% probability)

Intercept data

Intercept of radiocarbon age

with calibration curve: Cal AD 700 (Cal B P 1250)

1 Sigma calibrated result: Cal AD 680 to 770 (Cal B P 1270 to 1180 ) (68\% probability)

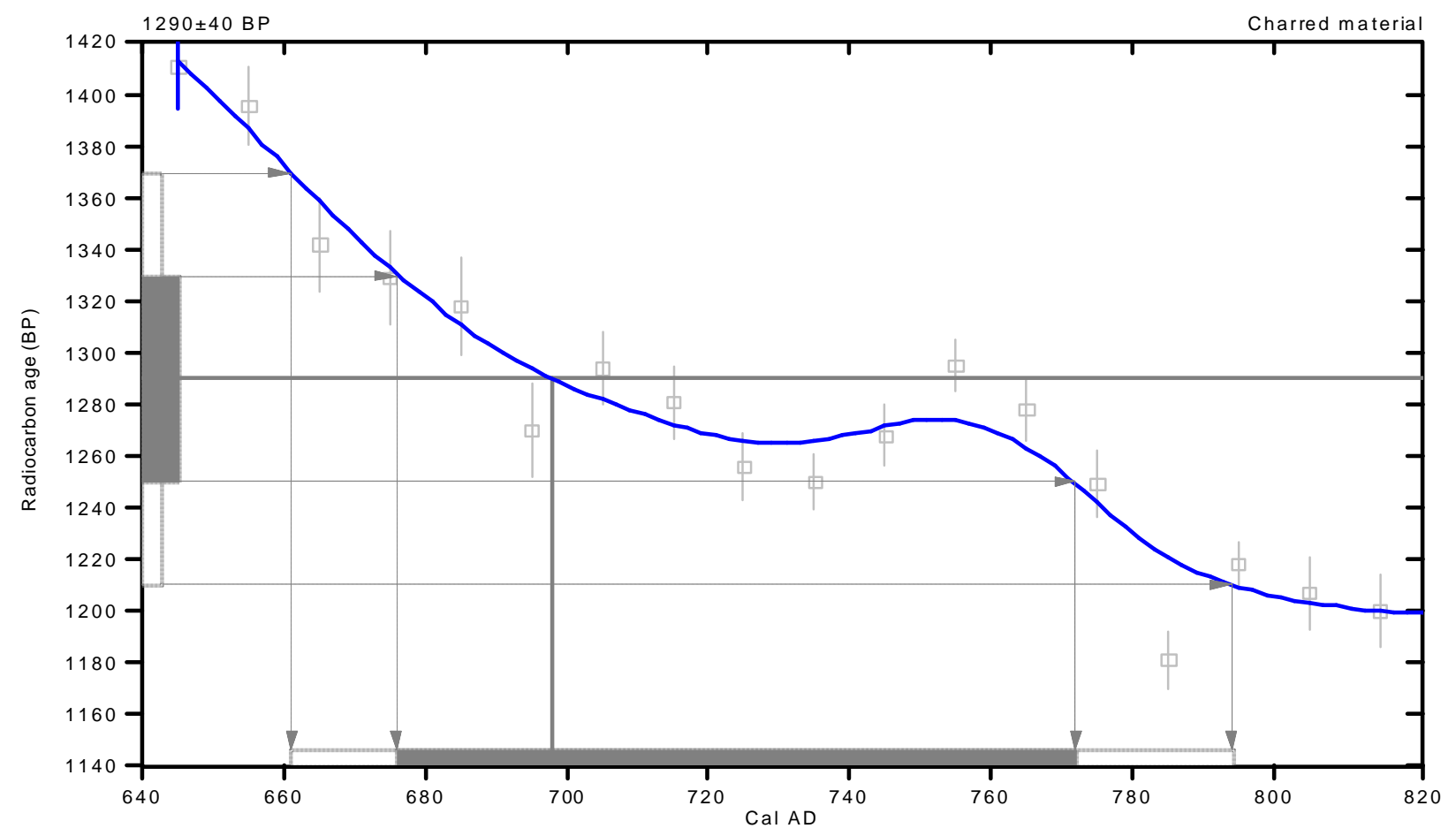

References:

Database used

Calibration Database

Editorial Com ment

Stuiver, M., van der Plicht, H., 1998, Radioca rbon 40(3), pxii-xiii

INTCAL98 Radiocarbon Age Calibration

Stuiver, M., et. al., 1998, Radiocarbon 40(3), p1041-1083

Mathe matics

A Simplified Approach to Calibrating C14 Dates

Talma, A. S., Vogel, J. C., 1993, Radiocarbon 35(2), p317-322

\section{Beta Analytic Inc.}

4985 SW 74 Court, Miami, Florida 33155 USA • Tel: (305)6675167・Fax:(305)6630964 • E-Mail: beta@ radiocarbon.com 


\section{CALIBRATION OF RADIOCARBON AGE TO CALENDAR YEARS}

(V ariables: C $13 / \mathrm{C} 12=-26.4: 1 \mathrm{ab} . \mathrm{mult}=1$ )

\section{Laboratory number: Beta-158819}

Conventional radiocarbon age: $1160 \pm 40 \mathrm{BP}$

2 Sigm a calibrated result: Cal AD 780 to 980 (Cal BP 1170 to 970 ) (95\% probability)

Intercept data

Intercept of radiocarbon age with calibration curve:

Cal AD $890(\mathrm{Cal}$ BP 1060$)$

1 Sigma calibrated results: Cal AD 810 to 840 (Cal B P 1140 to 1110) and (68\% probability) Cal AD 860 to 910 (Cal B P 1100 to 1040) and Cal AD 920 to 960 (Cal B P 1030 to 1000$)$

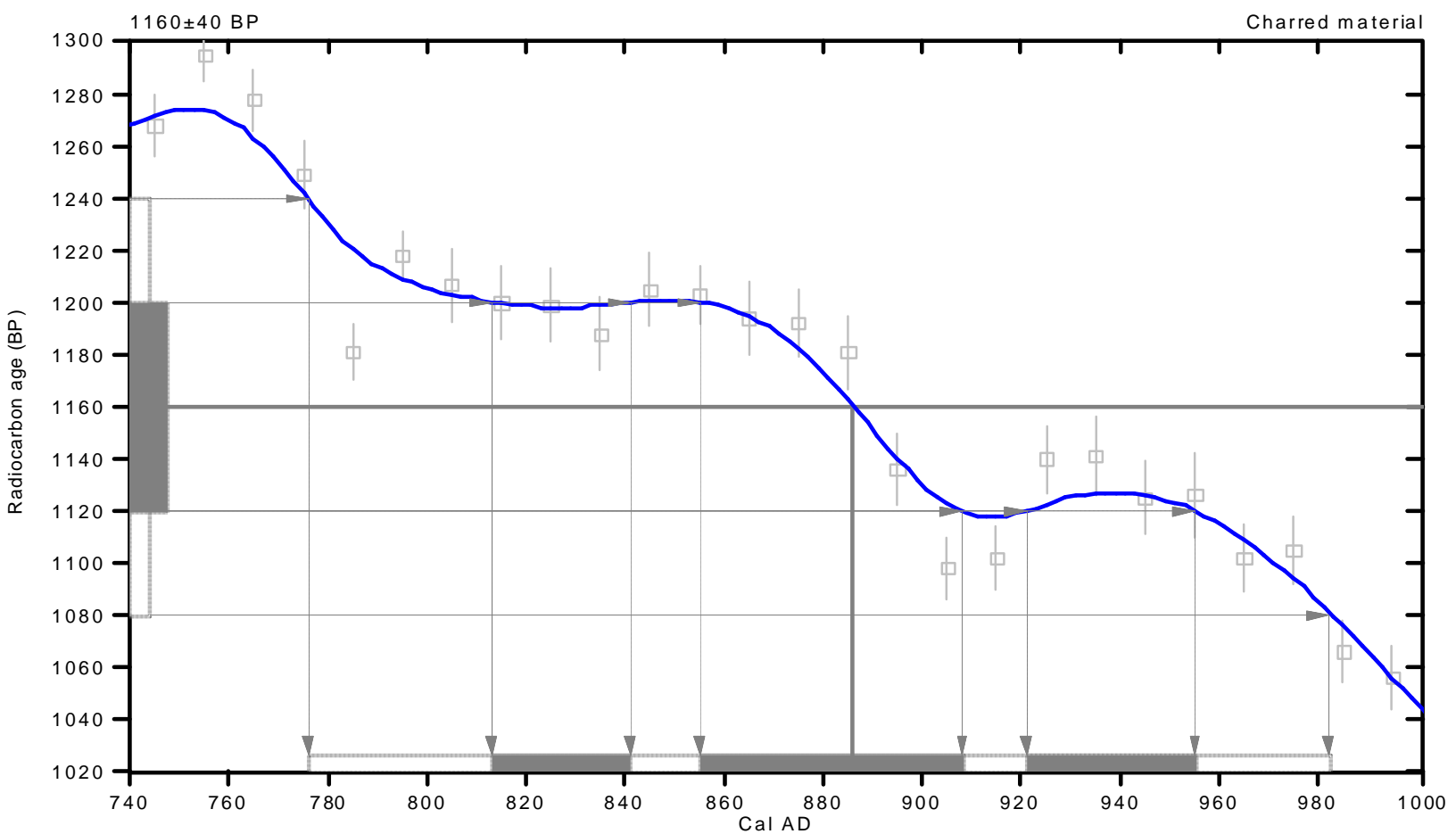

References:

Database used

Calibration Database Editorial Com ment

Stuiver, M., van der Plicht, H., 1998, Radioca rbon 40(3), pxii-xiii

INTCA L98 Radiocarbon Age Calibration

Stuiver, M., et. al., 1998, Radiocarbon 40(3), p1041-1083

Mathe matics

A Simplified Approach to Calibrating C14 Dates

Talma, A. S., Vogel, J. C., 1993, Radiocarbon 3 5(2), p317-322

\section{Beta Analytic Inc.}

4985 SW 74 Court, Miami, Florida 33155 USA $・$ Tel: (305) $6675167 \cdot$ Fax: (305) $6630964 \cdot$ E-Mail: beta@ radiocarbon.com 


\section{CALIBRATION OF RADIOCARBON AGE TO CALENDAR YEARS}

(V ariables: C13/C12=-26.6:1ab. mult=1)

Laboratory number: Beta-158820

Conventional radiocarbon age: $860 \pm 40$ BP

2 Sigm a calibrated result: Cal AD 1040 to 1260 (Cal BP 910 to 690)

(95\% probability)

Intercept data

Intercept of radiocarbon age

with calibration curve: Cal AD 1190 (Cal B P 760)

1 Sigm a calibrated result: Cal AD 1160 to 1230 (Cal BP 790 to 720 )

( $68 \%$ probability)

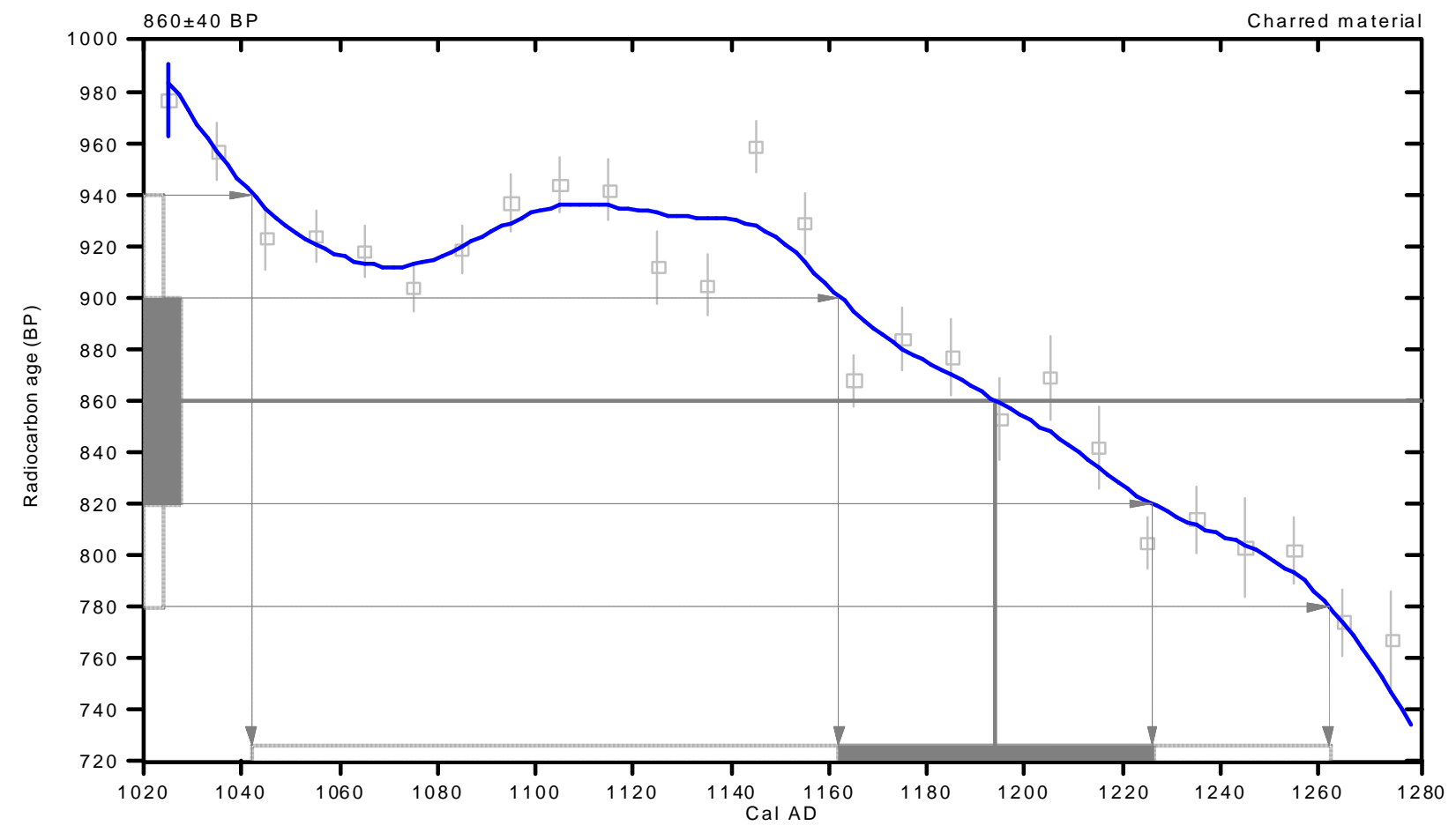

References:

Database used

Calibration Database

Editorial Com ment

Stuiver, M., van der Plicht, H., 1998, Radioca rbon 40(3), pxii-xiii

INTCAL98 Radiocarbon Age Calibration

Stuiver, M., et. al., 1998, Radiocarbon 40(3), p1041-1083

Mathematics

A Simplified Approach to Calibrating C14 Dates

Talma, A. S., Vogel, J. C., 1993, Radiocarbon 3 5(2), p317-322

\section{Beta Analytic Inc.}

4985 SW 74 Court, Miami, Florida 33155 USA • Tel: (305) $6675167 \cdot$ Fax: (305) $6630964 \cdot$ E-Mail: beta@ radiocarbon.com 


\section{CALIBRATION OF RADIOCARBON AGE TO CALENDAR YEARS}

(Variables: C13/C 12=-25.3:1ab. mult=1)

Laboratory number: Beta-158821

Conventional radiocarbon age: $1160 \pm 40 \mathrm{BP}$

2 Sigm a calibrated result: Cal AD 780 to 980 (Cal BP 1170 to 970 ) (95\% probability)

Intercept data

Intercept of radiocarbon age

with calibration curve:

Cal AD $890(\mathrm{Cal} B \mathrm{P} 1060)$

1 Sigma calibrated results: Cal AD 810 to 840 (Cal B P 1140 to 1110) and (68\% probability) Cal AD 860 to 910 (Cal B P 1100 to 1040) and Cal AD 920 to 960 (Cal B P 1030 to 1000)

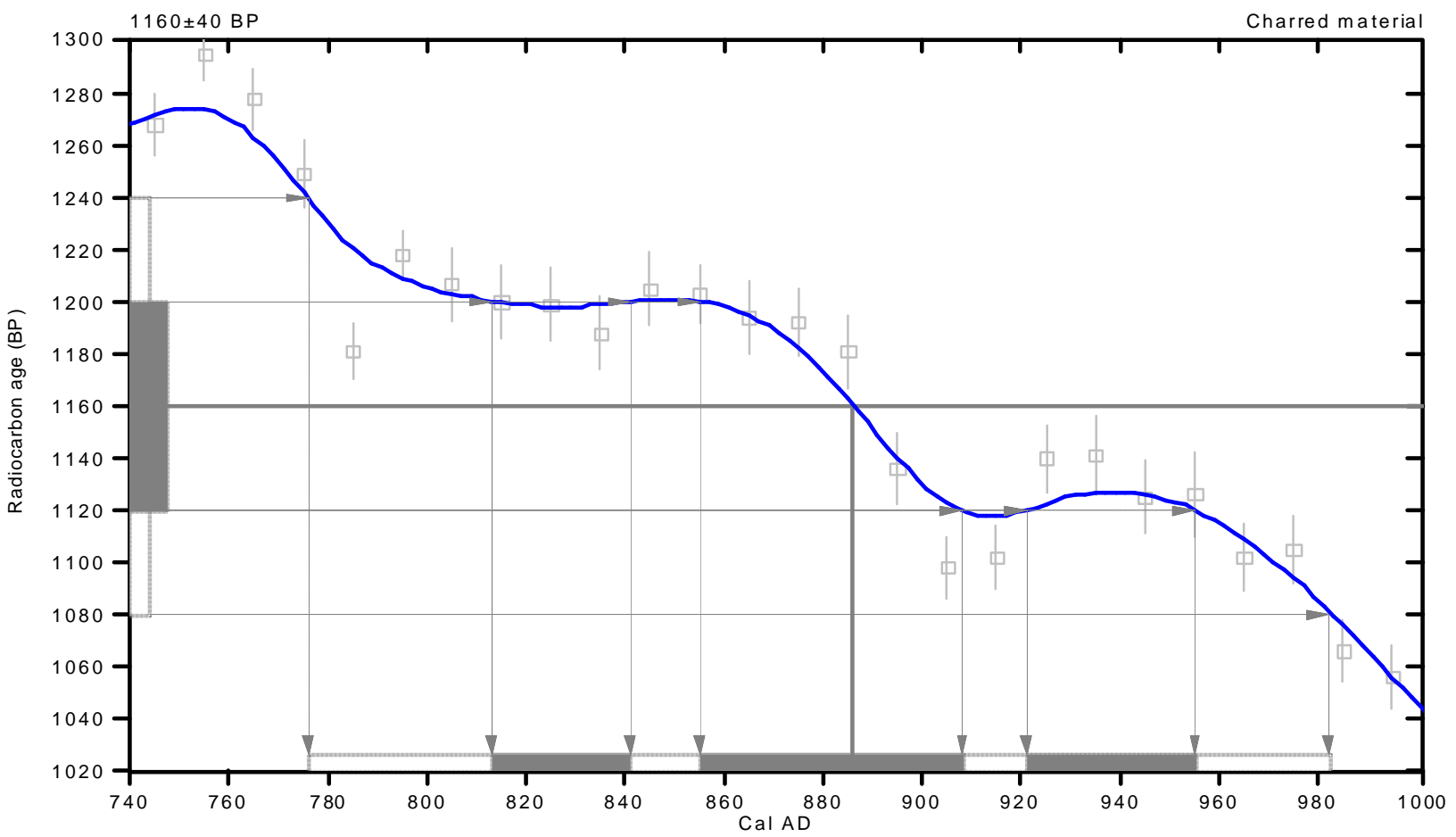

References:

Da tabase used

Calibration Database Editorial Com ment

Stuiver, M., van der Plicht, H., 1998, Radioca rbon 40(3), pxii-xiii

IN TCA L 98 Radiocarbon Age Calibration

Stuiver, M., et. al., 1998, Radiocarbon 40(3), p1041-1083

Mathematics

A Simplified Approach to Calibrating C14 Dates

Talma, A. S., Vogel, J. C., 1993, Radiocarbon 35(2), p317-322

\section{Beta Analytic Inc.}

4985 SW 74 Court, Miami, Florida 33155 USA $・$ Tel: (305) $6675167 \cdot$ Fax: (305) $6630964 \cdot$ E-Mail: beta@ radiocarbon.com 


\section{CALIBRATION OF RADIOCARBON AGE TO CALENDAR YEARS}

(V ariables: C 13/C12=-25.7:1ab. mult=1)

Laboratory number: Beta-158822

Conventional radiocarbon age: $1140 \pm 40$ BP

2 Sigm a calibrated result: Cal AD 790 to 990 (Cal BP 1160 to 960 )

(95\% probability)

Intercept data

Intercept of radiocarbon age

with calibration curve: Cal AD 900 (Cal B P 1060)

1 Sigma calibrated result: Cal AD 880 to 970 (Cal B P 1070 to 980) ( $68 \%$ probability)

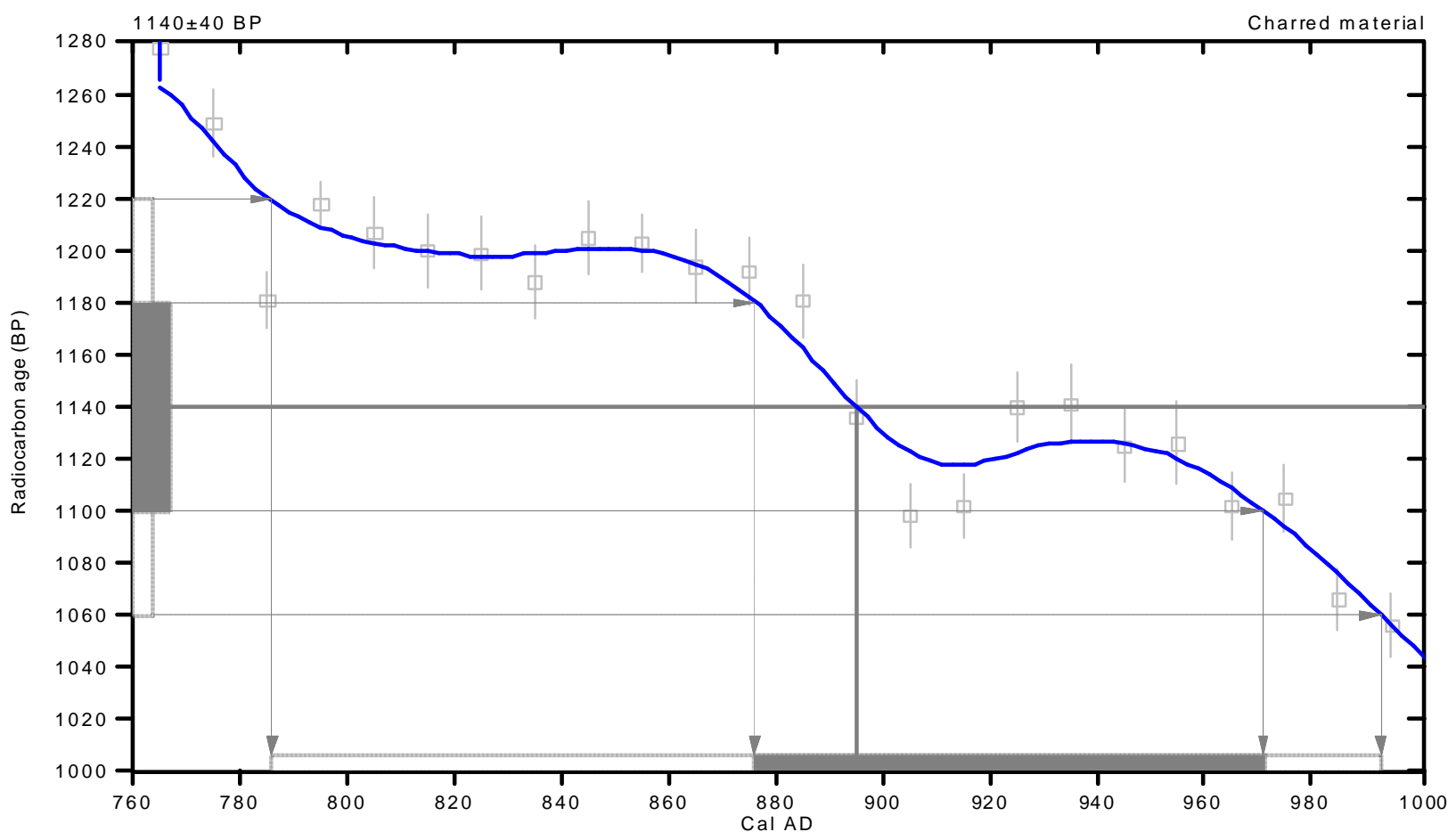

References :

Database used

Calibration Database

Editorial Com ment

Stuiver, M., van der Plicht, H., 1998, Radioca rbon 40(3), pxii-xiii

INTCAL98 Radiocarbon Age Calibration

Stuiver, M., et. al., 1998, Radiocarbon 40(3), p1041-1083

$M$ athe matics

A Simplified Approach to Calibrating C14 Dates

Talma, A. S., Vogel, J. C., 1993, Radiocarbon 35(2), p317-322

\section{Beta Analytic Inc.}

4985 SW 74 Court, Miami, Florida 33155 USA • Tel: (305) $6675167 \cdot$ Fax: (305) $6630964 \cdot$ E-Mail: beta@ radiocarbon.com 


\section{CALIBRATION OF RADIOCARBON AGE TO CALENDAR YEARS}

(Variables: C $13 / \mathrm{C} 12=-26.3: 1 \mathrm{ab} . \mathrm{mult}=1$ )

Laboratory number: Beta-158823

Conventional radiocarbon age: $970 \pm 40$ BP

2 Sigm a calibrated result: Cal AD 1000 to 1170 (Cal BP 950 to 780 )

(95\% probability)

Intercept data

Intercept of radiocarbon age

with calibration curve: Cal AD 1030 (Cal B P 920)

1 Sigma calibrated results: Cal AD 1020 to 1050 (Cal BP 930 to 900) and

(68\% probability) Cal AD 1100 to 1140 (Cal BP 850 to 810 )

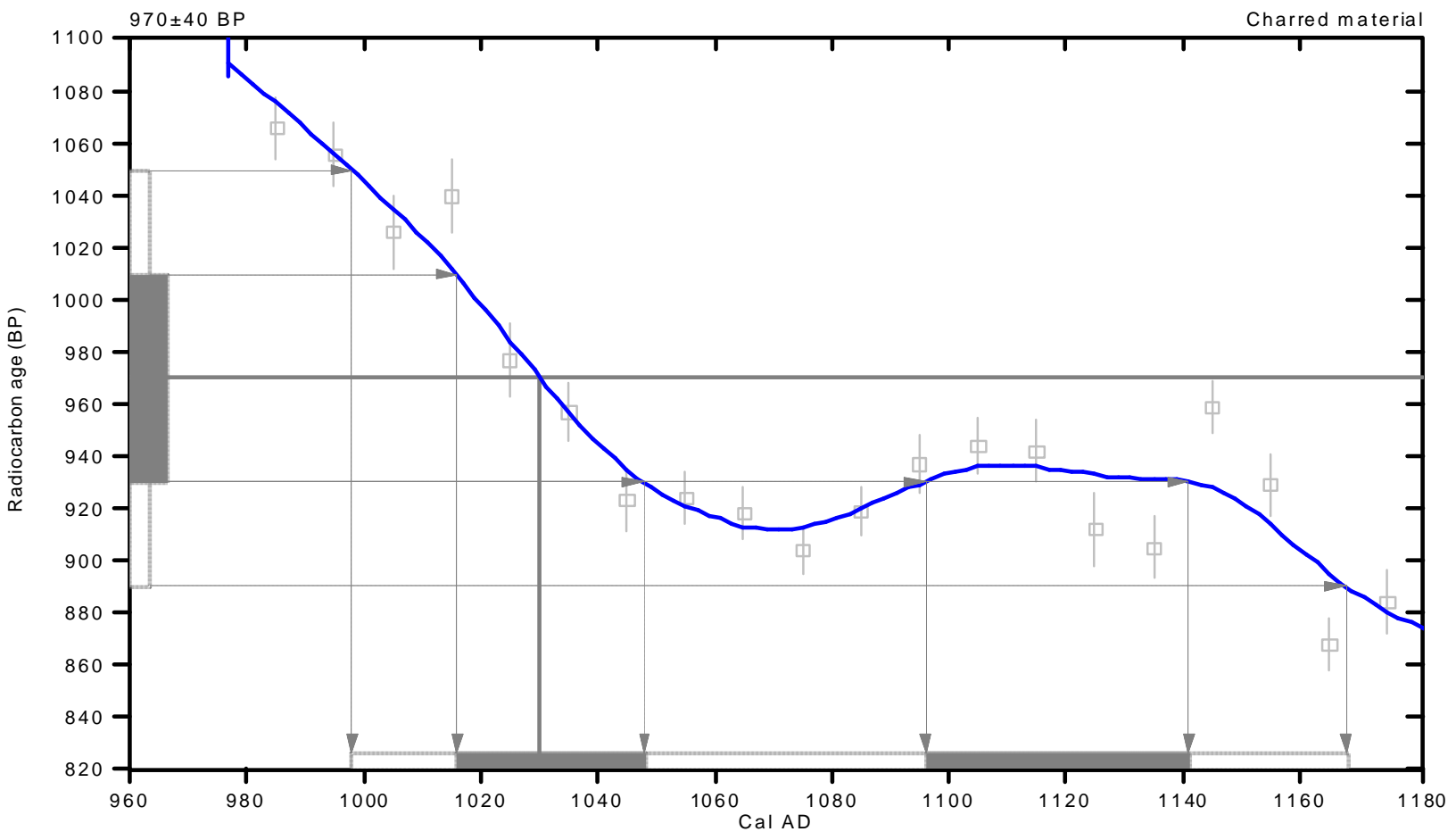

References:

Database used

Calibration Database

Editorial Com ment

Stuiver, M., van der Plicht, H., 1998, Radioca rbon 40(3), pxii-xiii

INTCAL98 Radiocarbon Age Calibration

Stuiver, M., et. al., 1998, Radiocarbon 40(3), p1041-1083

Mathe matics

A Simplified Approach to Calibrating C14 Dates

Talma, A. S., Vogel, J. C., 1993, Radiocarbon 35(2), p317-322

\section{Beta Analytic Inc.}

4985 SW 74 Court, Miami, Florida 33155 USA Pel: (305) 6675167 •Fax: (305) 6630964 • E-Mail: beta@ radiocarbon.com 


\section{CALIBRATION OF RADIOCARBON AGE TO CALENDAR YEARS}

(V ariables: C 13/C12=-22.7:1ab. mult=1)

Laboratory number: Beta-158824

Conventional radiocarbon age: $880 \pm 40$ BP

2 Sigm a calibrated result: Cal AD 1030 to 1250 (Cal BP 920 to 700 )

(95\% probability)

Intercept data

Intercept of radiocarbon age

with calibration curve: Cal AD 1180 (Cal B P 780)

1 Sigma calibrated results: Cal AD 1060 to 1080 (Cal BP 890 to 860) and

(68\% probability) Cal AD 1150 to 1210 (Cal BP 800 to 740)

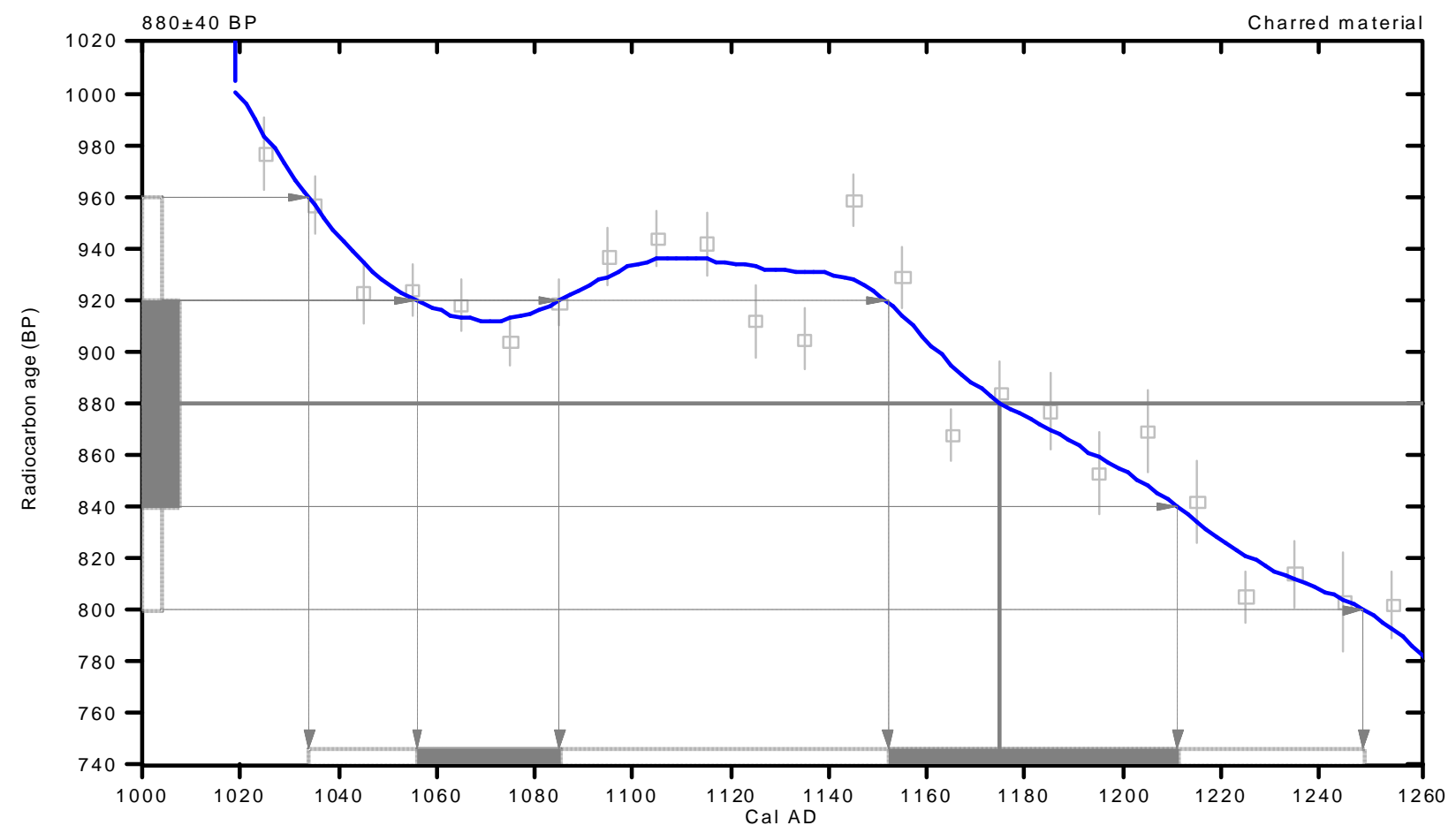

References:

Database used

Calibration Database

Editorial Com ment

Stuiver, M., van der Plicht, H., 1998, Radioca rbon 40(3), pxii-xiii

INTCAL98 Radiocarbon Age Calibration

Stuiver, M., et. al., 1998, Radiocarbon 40(3), p1041-1083

Mathematics

A Simplified Approach to Calibrating C14 Dates

Talma, A. S., Vogel, J. C., 1993, Radiocarbon 35(2), p317-322

\section{Beta Analytic Inc.}

4985 SW 74 Court, Miami, Florida 33155 USA • Tel: (305) $6675167 \cdot$ Fax: (305) $6630964 \cdot$ E-Mail: beta@ radiocarbon.com 


\section{CALIBRATION OF RADIOCARBON AGE TO CALENDAR YEARS}

(V ariables: C $13 / \mathrm{C} 12=-24: 1 \mathrm{ab} . \mathrm{mult}=1$ )

Laboratory number: Beta-158825

Conventional radiocarbon age: $1240 \pm 40 \mathrm{BP}$

2 Sigm a calibrated result: Cal AD 680 to 890 (Cal BP 1270 to 1060) (95\% probability)

Intercept data

Intercept of radiocarbon age

with calibration curve: Cal AD 780 (Cal B P 1170)

1 Sigma calibrated results: Cal AD 710 to 810 (Cal B P 1240 to 1140) and (68\% probability) Cal AD 840 to 860 (Cal B P 1110 to 1100)

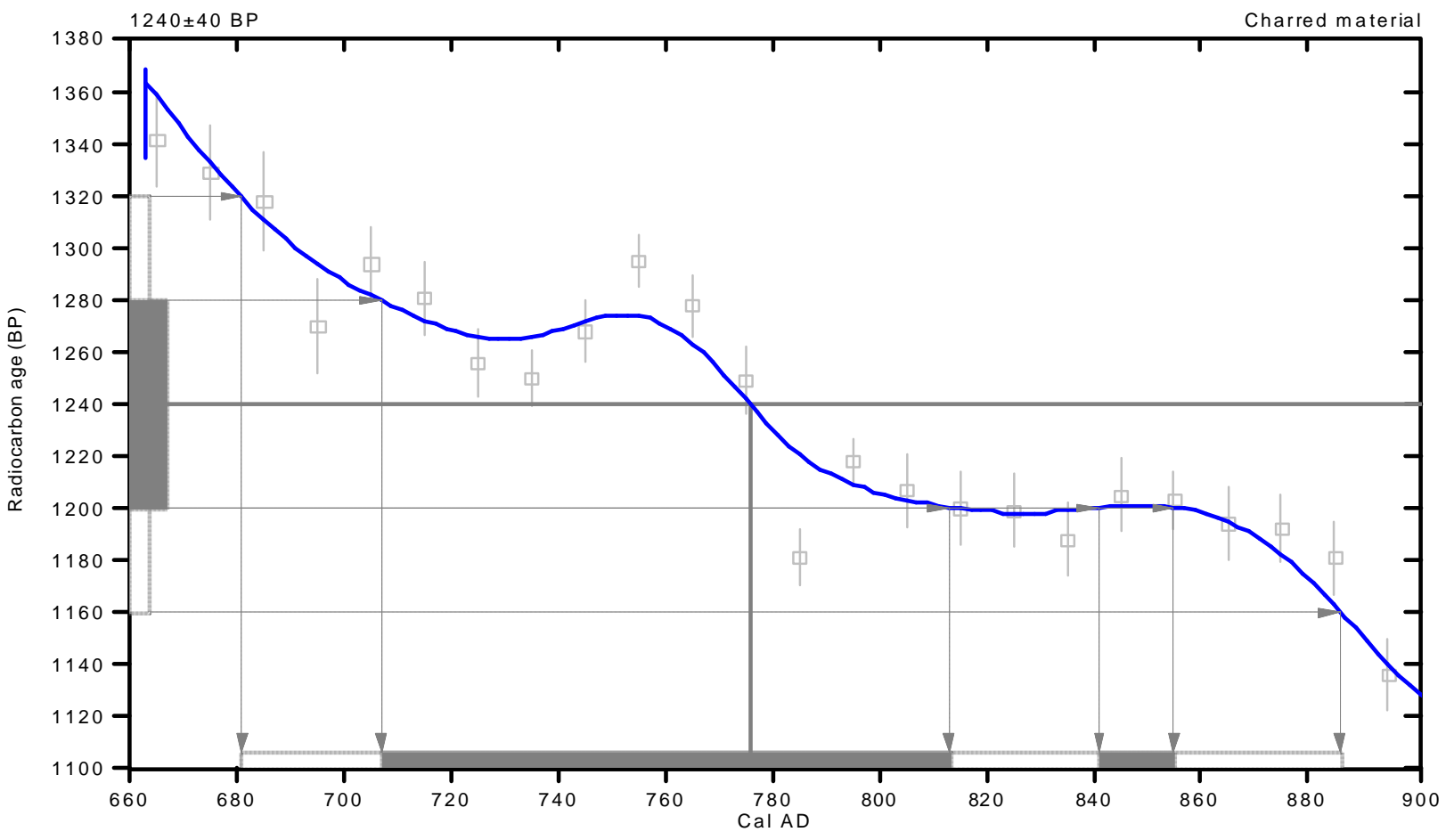

References:

Database used

Calibration Databa se

Editorial Com ment

Stuiver, M., van der Plicht, H., 1998, Radioca rbon 40(3), pxii-xiii

IN TCA L98 Radiocarbon Age Calibration

Stuiver, M., et. al., 1998, Radiocarbon 40(3), p1041-1083

Mathe matics

A Simplified Approach to Calibrating C14 Dates

Talma, A.S., Vogel, J. C., 1993, Radiocarbon 3 5(2), p317-322

\section{Beta Analytic Inc.}

4985 SW74 Court,Miami, Florida 33155 USA Tel: (305)6675167•Fax: (305)6630964 E-Mail: beta@ radiocarbon.com 


\section{CALIBRATION OF RADIOCARBON AGE TO CALENDAR YEARS}

(V ariables: C $13 / \mathrm{C} 12=-24.5: 1 \mathrm{ab} . \mathrm{mult}=1$ )

Laboratory number: Beta-158826

Conventional radiocarbon age: $2520 \pm 60$ BP

2 Sigm a calibrated result: Cal BC 810 to 410 (Cal BP 2760 to 2360)

(95\% probability)

Intercept data

Intercept of radiocarbon age

with calibration curve:

Cal B C 770 (Cal B P 2720)

1 Sigma calibrated results: Cal B C 790 to 740 (Cal B P 2740 to 2690) and

(68\% probability) Cal BC 710 to 530 (Cal B P 2660 to 2480)

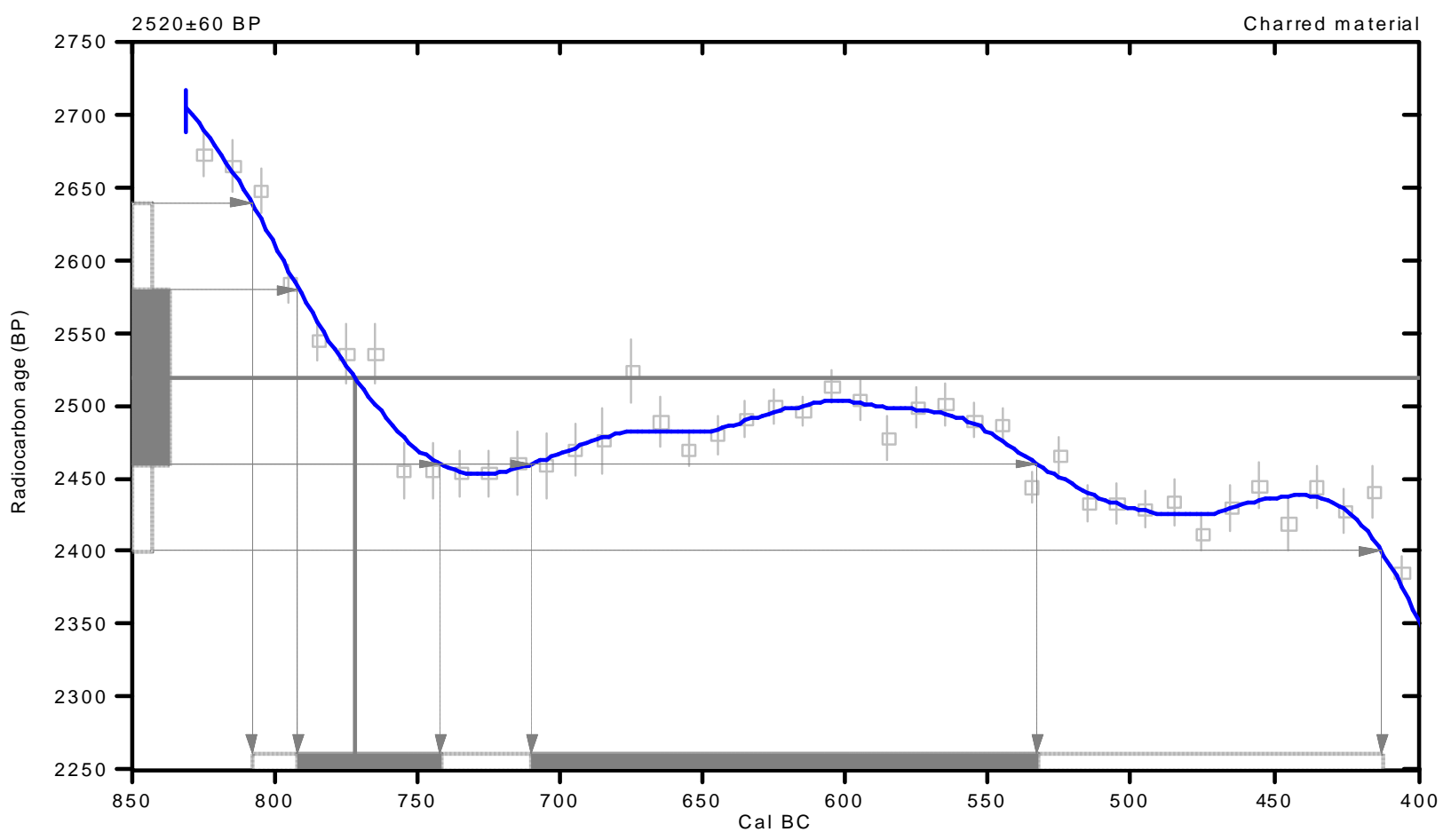

References :

Database used

Calibration Database

Editorial Com ment

Stuiver, M., van der Plicht, H., 1998, Radioca rbon 40(3), pxii-xiii

INTCAL98 Radiocarbon Age Calibration

Stuiver, M., et. al., 1998, Radiocarbon 40(3), p1041-1083

$M$ athe matics

A Simplified Approach to Calibrating C14 Dates

Talma, A. S., Vogel, J. C., 1993, Radiocarbon 35(2), p317-322

\section{Beta Analytic Inc.}

4985 SW 74 Court, Miami, Florida 33155 USA - Tel: (305) $6675167 \cdot$ Fax: (305) $6630964 \cdot$ E-Mail: beta@ radiocarbon.com 


\section{CALIBRATION OF RADIOCARBON AGE TO CALENDAR YEARS}

(Variables: C $13 / \mathrm{C} 12=-25.5: 1 \mathrm{ab} . \mathrm{mult}=1$ )

Laboratory number: Beta-158827

Conventional radiocarbon age: $790 \pm 50 \mathrm{BP}$

2 Sigm a calibrated result: Cal AD 1170 to 1290 (Cal BP 780 to 660)

(95\% probability)

Intercept data

Intercept of radiocarbon age

with calibration curve: Cal AD 1260 (Cal B P 690)

1 Sigm a calibrated result: Cal AD 1210 to 1280 (Cal BP 740 to 670) (68\% probability)

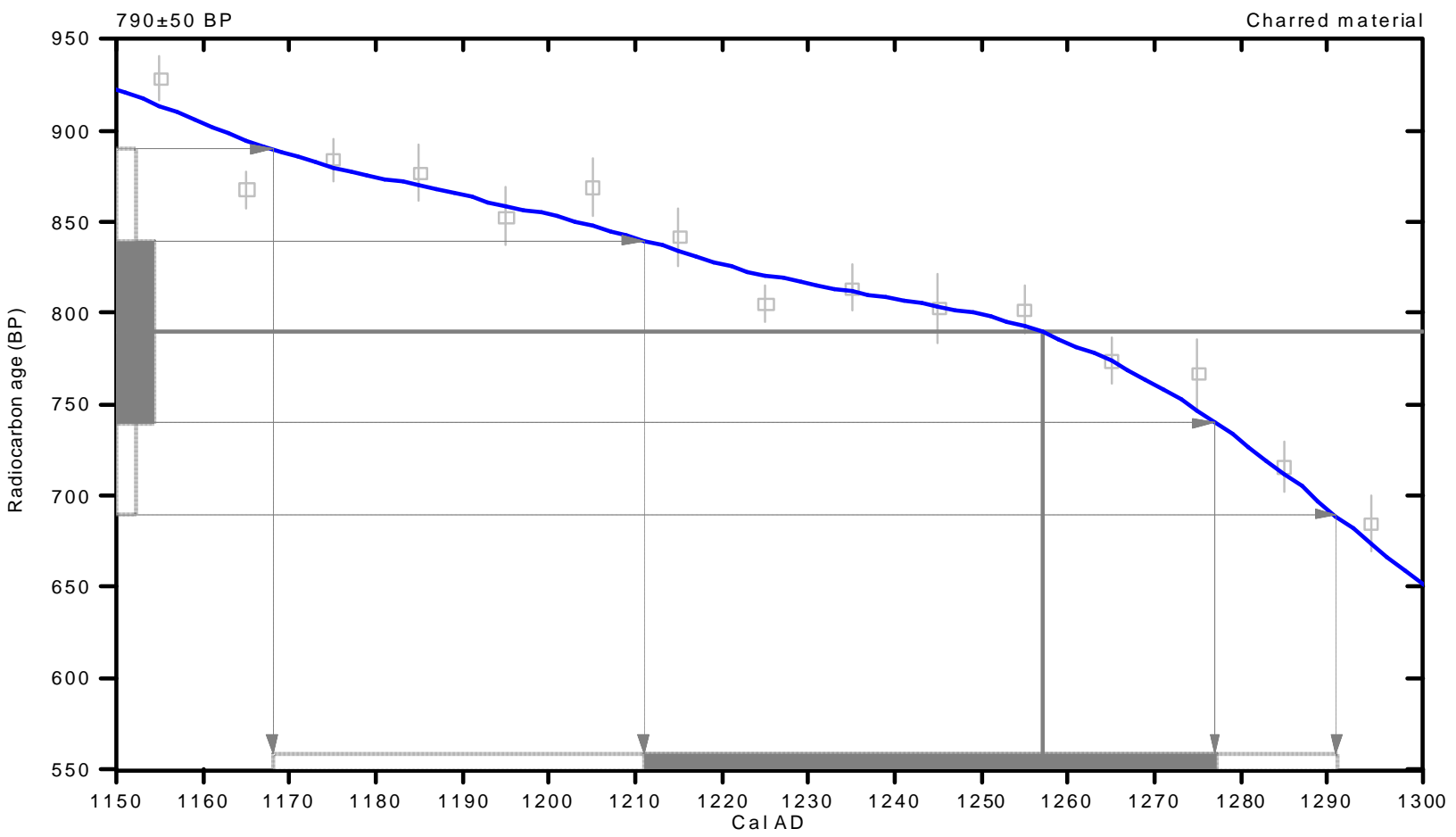

References:

Database used

Calibration Database

Editorial Com ment

Stuiver, M., van der Plicht, H., 1998, Radioca rbon 40(3), pxii-xiii

INTCA L98 Radiocarbon Age Calibration

Stuiver, M., et. al., 1998, Radiocarbon 40(3), p1041-1083

Mathematics

A Simplified Approach to Calibrating C14 Dates

Talma, A. S., Vogel, J. C., 1993, Radiocarbon 3 5(2), p317-322

\section{Beta Analytic Inc.}

4985 SW 74 Court, Miami, Florida 33155 USA $・$ Tel: (305) $6675167 \cdot$ Fax: (305) $6630964 \cdot$ E-Mail: beta@ radiocarbon.com 


\section{CALIBRATION OF RADIOCARBON AGE TO CALENDAR YEARS}

(V ariables: C $13 / \mathrm{C} 12=-25.1: 1 \mathrm{ab} . \mathrm{mult}=1$ )

Laboratory number: Beta-159517

Conventional radiocarbon age: $930 \pm 70$ BP

2 Sigm a calibrated result: Cal AD 990 to 1260 (Cal BP 960 to 690)

(95\% probability)

Intercept data

Intercepts of radiocarbon age

with calibration curve: Cal AD 1050 (Cal BP 900) and

Cal AD 1100 (Cal BP 850) and

Cal AD 1140 (Cal BP 810$)$

1 Sigm a calibrated result:

Cal AD 1020 to 1190 (Cal BP 930 to 760) (68\% probability)

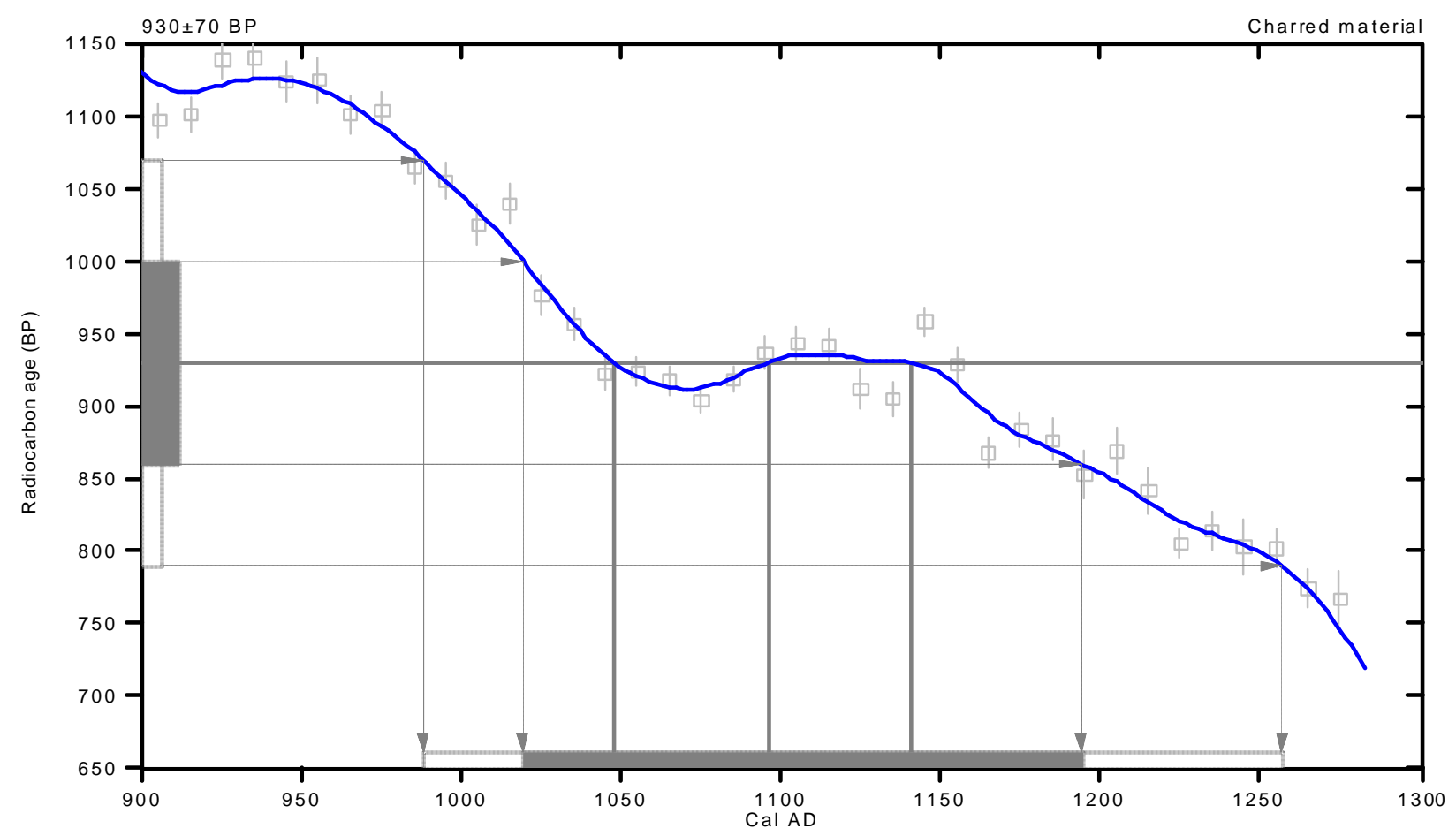

References:

Database used

Calibration Database

Editorial Com ment

Stuiver, M., van der Plicht, H., 1998, Radioca rbon 40(3), pxii-xiii

INTCA L98 Radiocarbon Age Calibration

Stuiver, M., et. al., 1998, Radiocarbon 40(3), p1041-1083

Mathematics

A Simplified Approach to Calibrating C14 Dates

Talma, A. S., Vogel, J. C., 1993, Radiocarbon 35(2), p317-322

\section{Beta Analytic Inc.}

4985 SW 74 Court, Miami, Florida 33155 USA $\cdot$ Tel: (305) $6675167 \cdot$ Fax: (305) $6630964 \cdot$ E-Mail: beta@ radiocarbon.com 


\section{CALIBRATION OF RADIOCARBON AGE TO CALENDAR YEARS}

(Variables: C13/C 12=-26.8:1ab. mult=1)

Laboratory number: Beta-159518

Conventional radiocarbon age: $1500 \pm 40 \mathrm{BP}$

2 Sigm a calibrated result: Cal AD 450 to 640 (Cal BP 1500 to 1310)

(95\% probability)

Intercept data

Intercept of radiocarbon age with calibration curve:

Cal AD 570 (Cal BP 1380)

1 Sigm a calibrated result: (68\% probability)

Cal AD 540 to 620 (Cal B P 1410 to 1330)

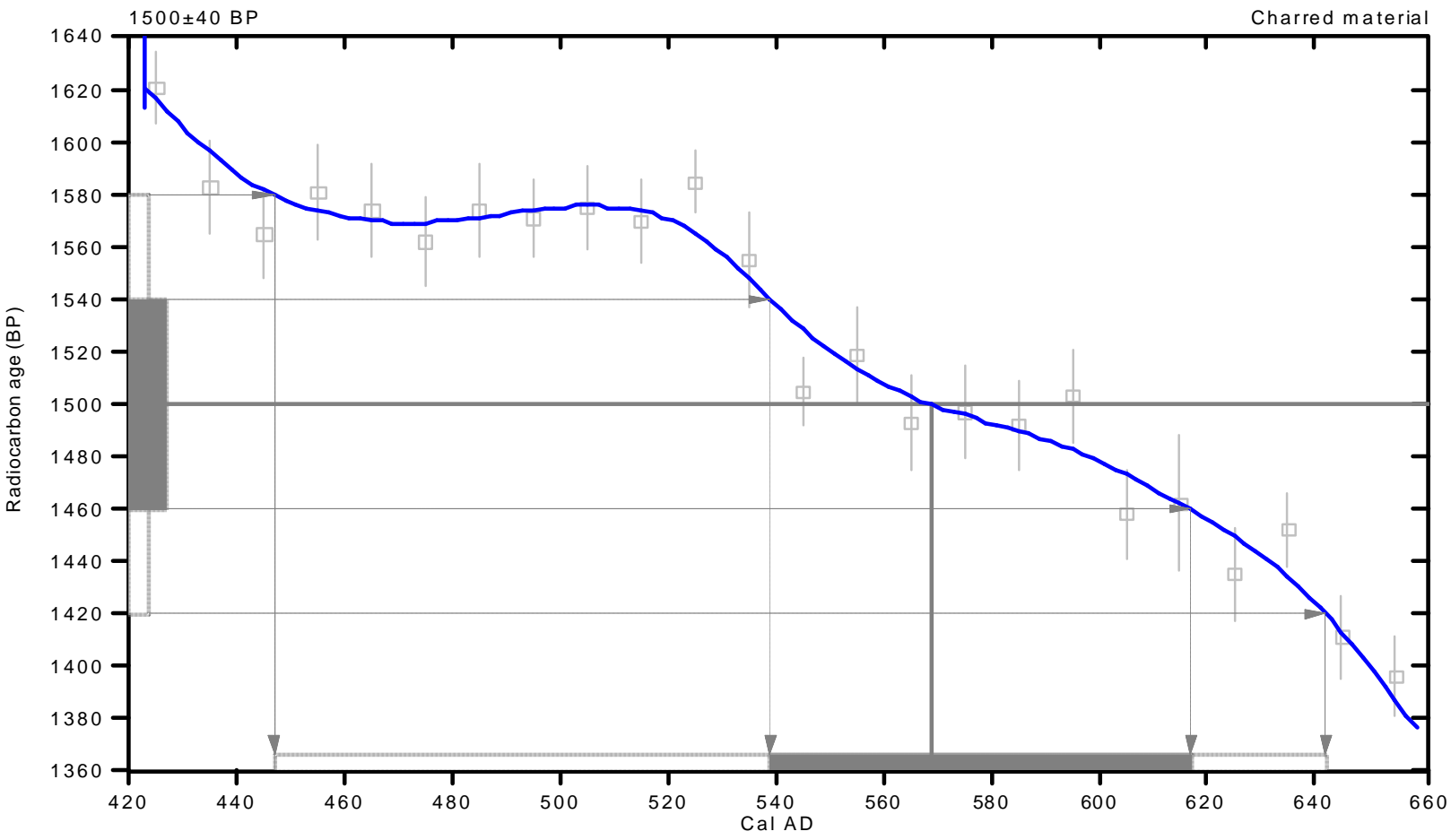

References:

Da tabase used

Calibration Database

Editorial Com ment

Stuiver, M., van der Plicht, H., 1998, Radioca rbon 40(3), pxii-xiii

IN TCA L98 Radiocarbon Age Calibration

Stuiver, M., et. al., 1998, Radiocarbon 40(3), p1041-1083

Mathe matics

A Simplified Approach to Calibrating C14 Dates

Talma, A. S., Vogel, J. C., 1993, Radiocarbon 3 5(2), p317-322

\section{Beta Analytic Inc.}

4985 SW 74 Court, Miami, Florida 33155 USA Pel: (305)6675167•Fax:(305) $6630964 \cdot$ E-Mail: beta@ radiocarbon.com 


\section{CALIBRATION OF RADIOCARBON AGE TO CALENDAR YEARS}

(Variables: C13/C12=-25.9:1ab. mult =1)

Laboratory number: Beta-159519

Conventional radiocarbon age: $900 \pm 50$ BP

2 Sigm a calibrated result: Cal AD 1020 to 1250 (Cal BP 930 to 700 )

(95\% probability)

Intercept data

Intercept of radiocarbon age

with calibration curve: Cal AD 1160 (Cal B P 790)

1 Sigm a calibrated result: Cal AD 1040 to 1200 (Cal BP 910 to 750 )

$(68 \%$ probability)

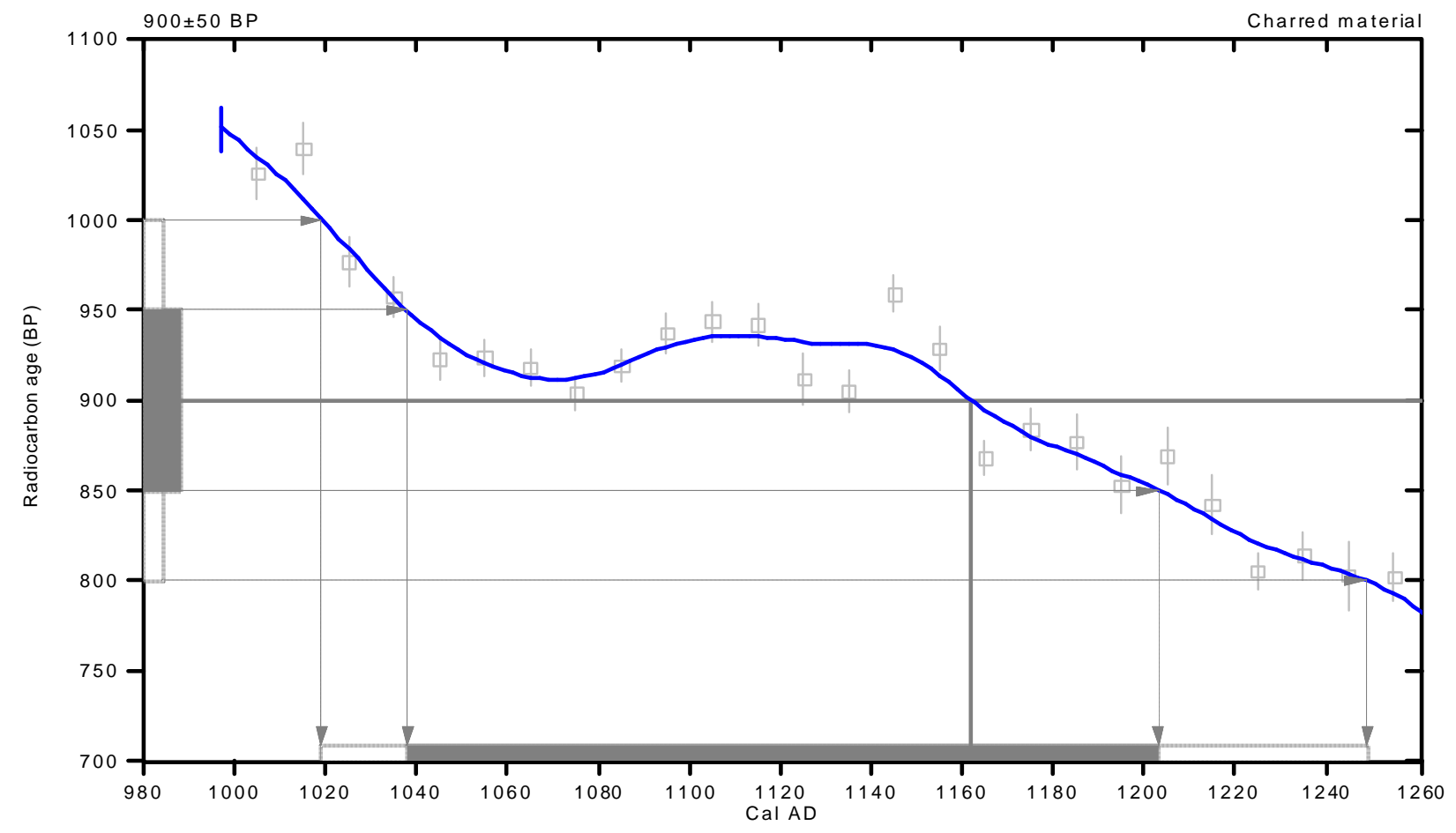

References:

Database used

Calibration Database

Editorial Com ment

Stuiver, M., van der Plicht, H., 1998, Radioca rbon 40(3), pxii-xiii

INTCAL98 Radiocarbon Age Calibration

Stuiver, M., et. al., 1998, Radiocarbon 40(3), p1041-1083

Mathematics

A Simplified Approach to Calibrating C14 Dates

Talma, A. S., Vogel, J. C., 1993, Radiocarbon 35(2), p317-322

\section{Beta Analytic Inc.}

4985 SW 74 Court, Miami, Florida 33155 USA • Tel: (305) $6675167 \cdot$ Fax: (305) $6630964 \cdot$ E-Mail: beta@ radiocarbon.com 


\section{CALIBRATION OF RADIOCARBON AGE TO CALENDAR YEARS}

(Variables: C $13 / \mathrm{C} 12=-22.2: 1 \mathrm{ab} . \mathrm{mult}=1$ )

Laboratory number: Beta-159520

Conventional radiocarbon age: $1190 \pm 60 \mathrm{BP}$

2 Sigm a calibrated result: Cal AD 690 to 990 (Cal BP 1260 to 960 )

(95\% probability)

Intercept data

Intercept of radiocarbon age

with calibration curve: Cal AD 870 (Cal B P 1080)

1 Sigm a calibrated result: Cal AD 770 to 900 (Cal B P 1180 to 1050) (68\% probability)

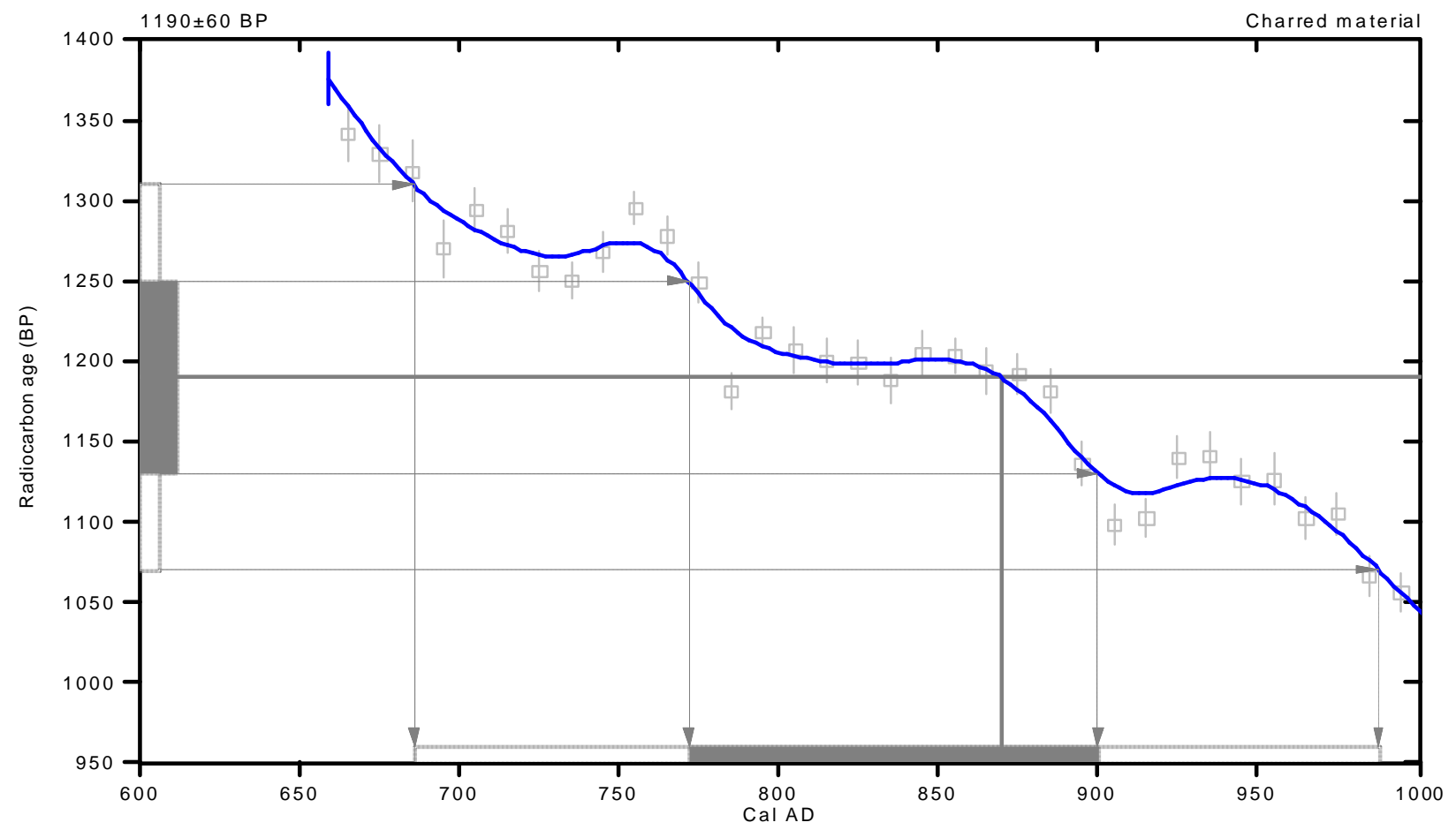

References:

Database used

Calibration Database

Editorial Com ment

Stuiver, M., van der Plicht, H., 1998, Radioca rbon 40(3), pxii-xiii

INTCAL98 Radiocarbon Age Calibration

Stuiver, M., et. al., 1998, Radiocarbon 40(3), p1041-1083

Mathe matics

A Simplified Approach to Calibrating C14 Dates

Talma, A. S., Vogel, J. C., 1993, Radiocarbon 35(2), p317-322

\section{Beta Analytic Inc.}

4985 SW 74 Court, Miami, Florida 33155 USA $・$ Tel: (305) $6675167 \cdot$ Fax: (305) $6630964 \cdot$ E-Mail: beta@ radiocarbon.com 


\section{CALIBRATION OF RADIOCARBON AGE TO CALENDAR YEARS}

(Variables: C13/C12=-24.9:1ab. mult=1)

Laboratory number: Beta-159521

Conventional radiocarbon age: $960 \pm 40 \mathrm{BP}$

2 Sigm a calibrated result: Cal AD 1000 to 1180 (Cal BP 950 to 780 )

(95\% probability)

Intercept data

Intercept of radiocarbon age

with calibration curve:

Cal AD 1030 (Cal BP 920)

1 Sigma calibrated results: Cal AD 1020 to 1060 (Cal BP 930 to 890) and

(68\% probability) Cal AD 1080 to 1150 (Cal BP 860 to 800 )

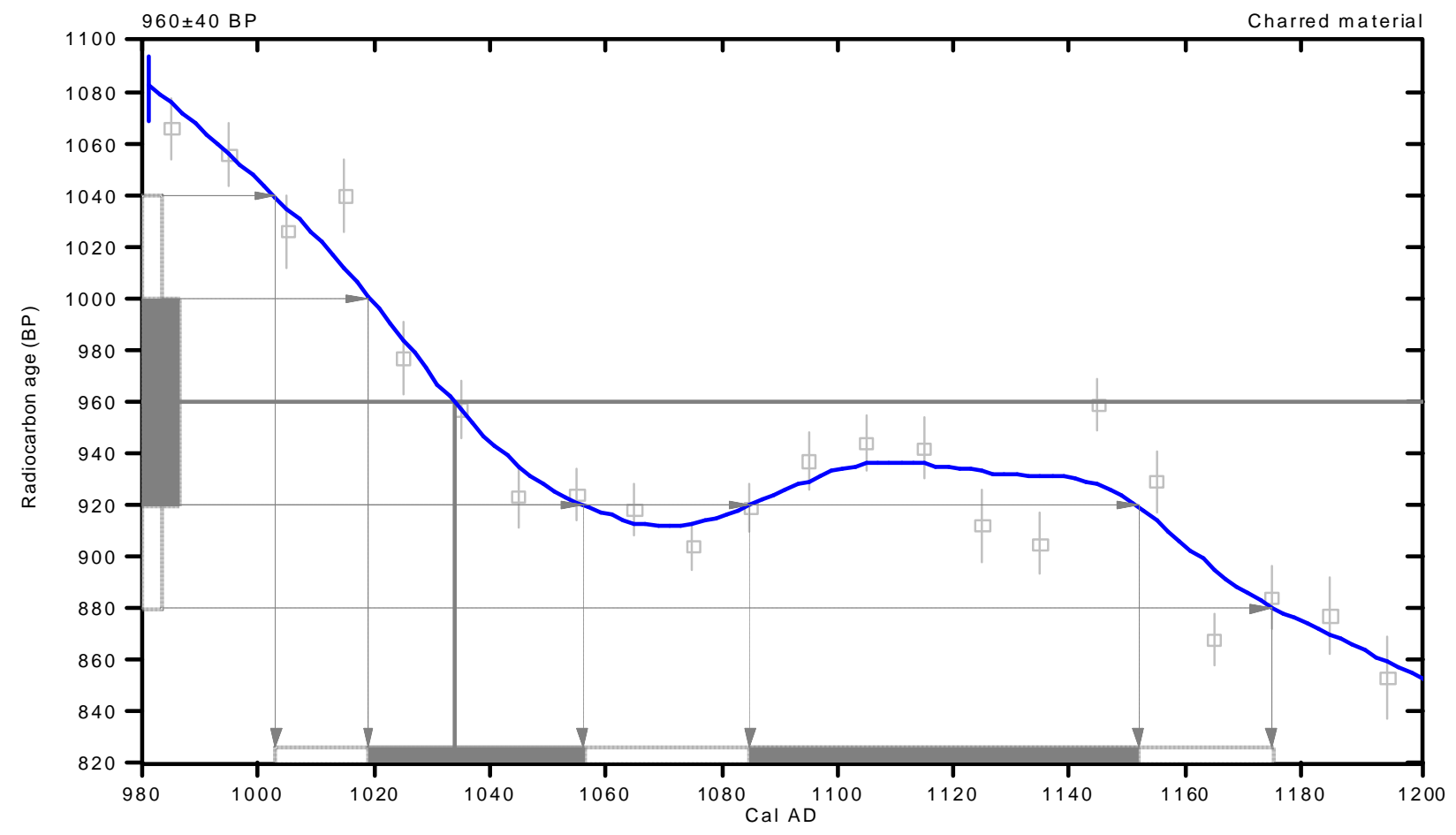

References :

Database used

Calibration Database

Editorial Com ment

Stuiver, M., van der Plicht, H., 1998, Radioca rbon 40(3), pxii-xiii

INTCAL98 Radiocarbon Age Calibration

Stuiver, M., et. al., 1998, Radiocarbon 40(3), p1041-1083

$M$ athe matics

A Simplified Approach to Calibrating C14 Dates

Talma, A.S., Vogel, J. C., 1993, Radiocarbon 35(2), p317-322

\section{Beta Analytic Inc.}

4985 SW 74 Court, Miami, Florida 33155 USA • Tel: (305) $6675167 \cdot$ Fax: (305) $6630964 \cdot$ E-Mail: beta@ radiocarbon.com 


\section{CALIBRATION OF RADIOCARBON AGE TO CALENDAR YEARS}

(Variables: C 13/C12=-24.3:1ab. mult=1)

Laboratory number: Beta-159522

Conventional radiocarbon age: $920 \pm 40$ BP

2 Sigm a calibrated result: Cal AD 1020 to 1210 (Cal BP 930 to 740 )

(95\% probability)

Intercept data

Intercepts of radiocarbon age

with calibration curve:

Cal AD 1060 (Cal BP 890$)$ and

Cal AD 1080 (Cal BP 860) and

Cal AD $1150(\mathrm{Cal}$ BP 800$)$

1 Sigm a calibrated result:

Cal AD 1030 to 1180 (Cal BP 920 to 780 )

(68\% probability)

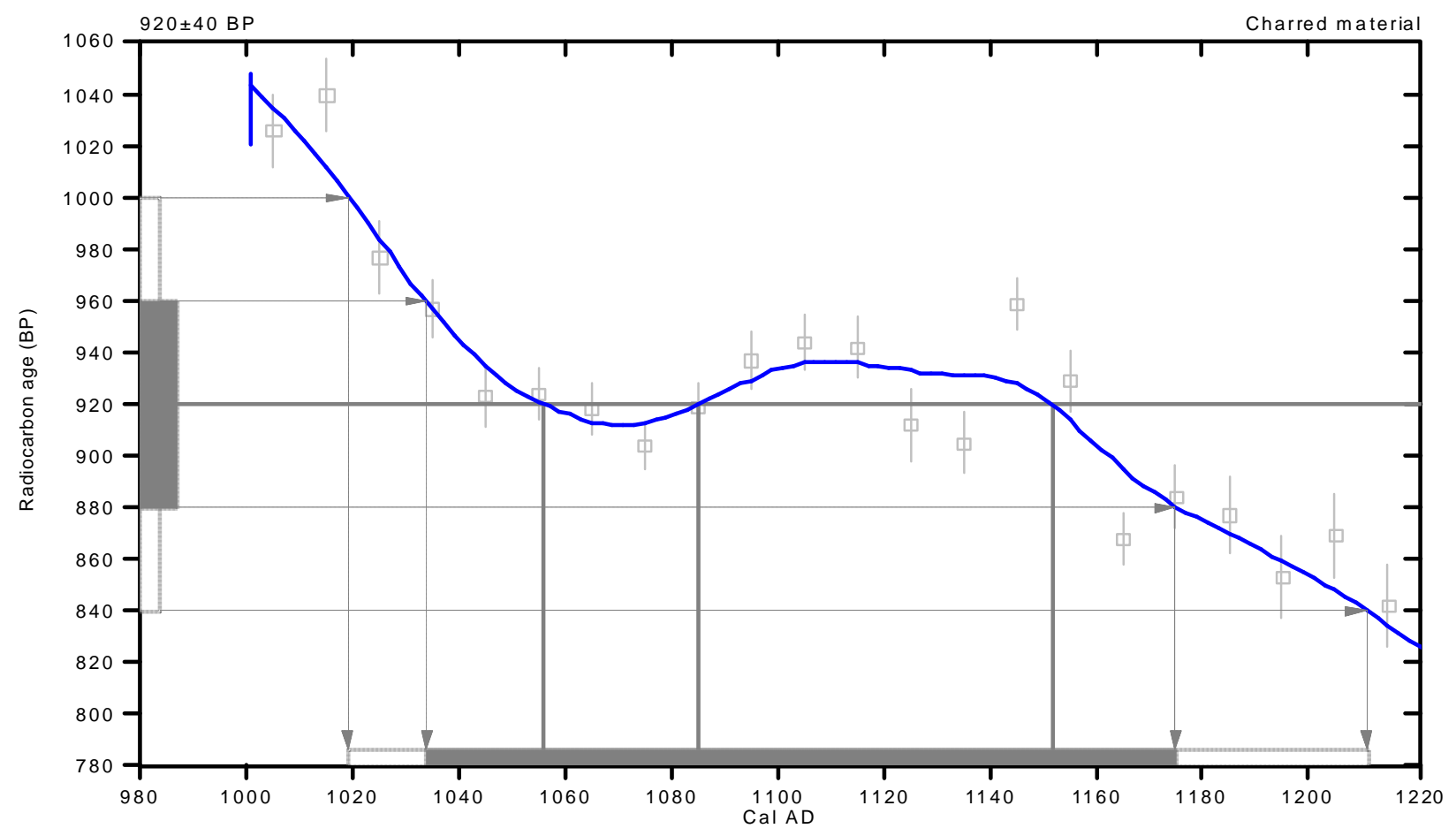

References:

Da tabase used

Calibration Database

Editorial Com ment

Stuiver, M., van der Plicht, H., 1998, Radioca rbon 40(3), pxii-xiii

IN TCA L98 Radiocarbon Age Calibration

Stuiver, M., et. al., 1998, Radiocarbon 40(3), p1041-1083

Mathe matics

A Simplified Approach to Calibrating C14 Dates

Talma, A. S., Vogel, J. C., 1993, Radiocarbon 35(2), p317-322

\section{Beta Analytic Inc.}

4985 SW 74 Court, Miami, Florida 33155 USA Pel: (305) 6675167 •Fax: (305) 6630964 • E-Mail: beta@ radiocarbon.com 


\section{CALIBRATION OF RADIOCARBON AGE TO CALENDAR YEARS}

(V ariables: C $13 / \mathrm{C} 12=-24.4: 1 \mathrm{ab} . \mathrm{mult}=1$ )

Laboratory number: Beta-160814

Conventional radiocarbon age: $850 \pm 40$ BP

2 Sigm a calibrated results: Cal AD 1050 to 1100 (Cal BP 900 to 850 ) and

(95\% probability) Cal AD 1140 to 1270 (Cal BP 810 to 680)

Intercept data

Intercept of radiocarbon age

with calibration curve: Cal AD 1200 (Cal B P 750)

1 Sigm a calibrated result: Cal AD 1170 to 1240 (Cal BP 780 to 710 )

(68\% probability)

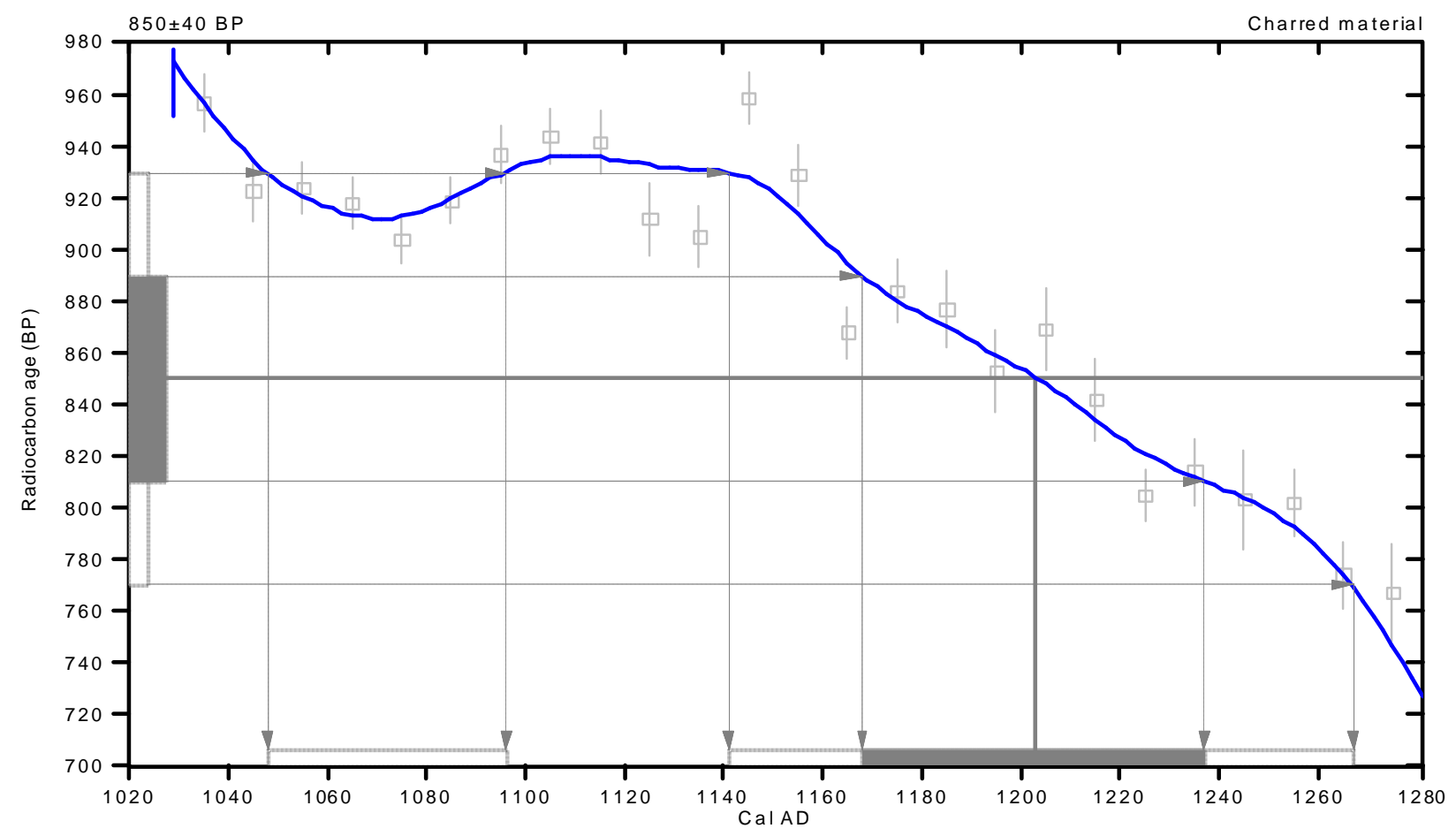

References :

Database used

Calibration Database

Editorial Com ment

Stuiver, M., van der Plicht, H., 1998, Radioca rbon 40(3), pxii-xiii

INTCAL98 Radiocarbon Age Calibration

Stuiver, M., et. al., 1998, Radiocarbon 40(3), p1041-1083

Mathematics

A Simplified Approach to Calibrating C14 Dates

Talma, A. S., Vogel, J. C., 1993, Radiocarbon 3 5(2), p317-322

\section{Beta Analytic Inc.}

4985 SW 74 Court, Miami, Florida 33155 USA • Tel: (305) $6675167 \cdot$ Fax: (305) $6630964 \cdot$ E-Mail: beta@ radiocarbon.com 


\section{CALIBRATION OF RADIOCARBON AGE TO CALENDAR YEARS}

(Variables: C $13 / \mathrm{C} 12=-25.5: 1 \mathrm{ab} . \mathrm{mult}=1$ )

Laboratory number: Beta-160815

Conventional radiocarbon age: $1040 \pm 40$ BP

2 Sigm a calibrated results: Cal AD 910 to 920 (Cal BP 1040 to 1030) and (95\% probability) Cal AD 960 to 1030 (Cal BP 1000 to 920)

Intercept data

Intercept of radiocarbon age with calibration curve:

Cal AD $1000($ Cal B P 950)

1 Sigma calibrated result: Cal AD 980 to 1020 (Cal B P 970 to 930) (68\% probability)

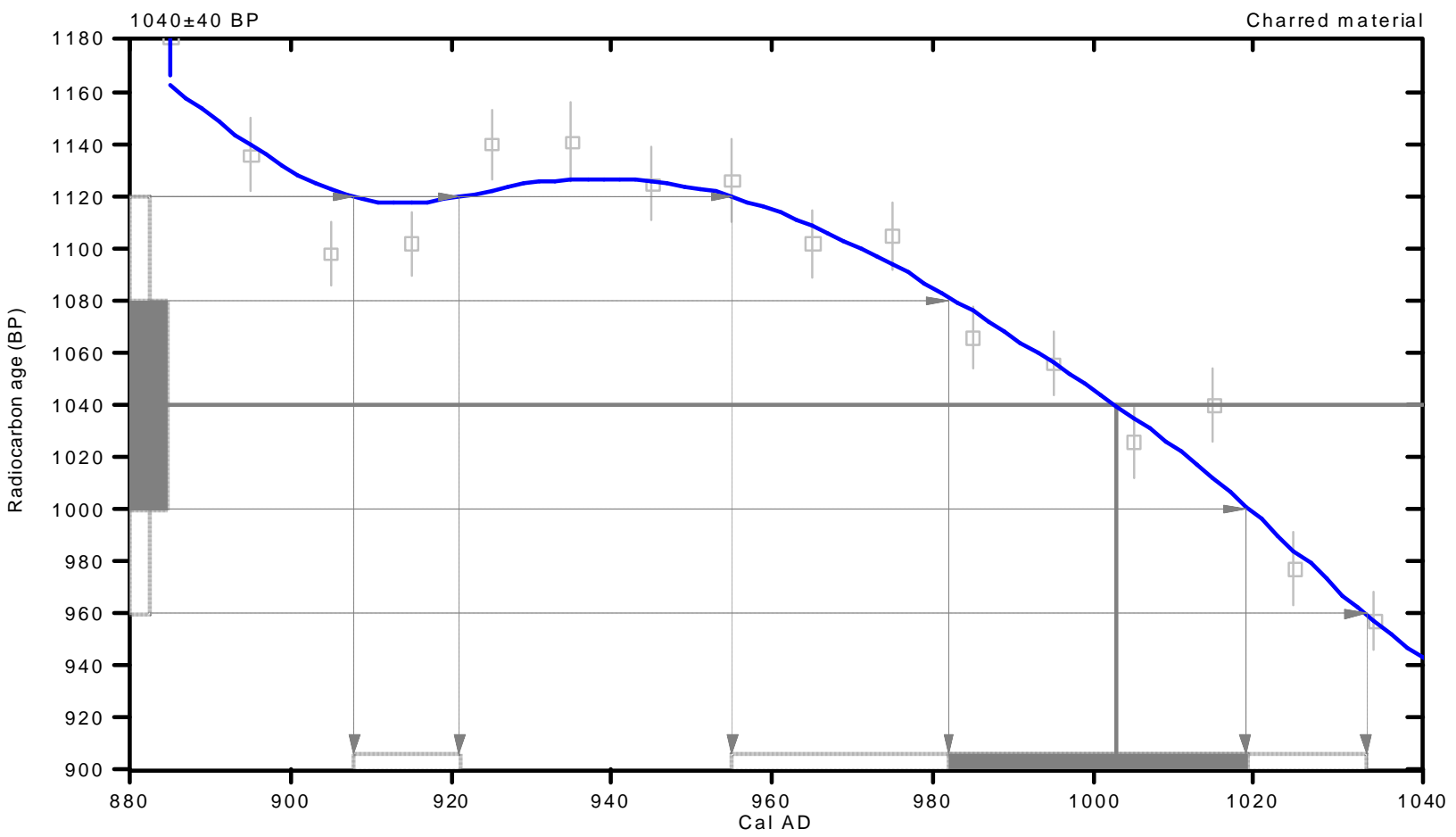

References:

Database used

Calibration Database Editorial Com ment

Stuiver, M., van der Plicht, H., 1998, Radioca rbon 40(3), pxii-xiii

IN TCA L98 Radiocarbon Age Calibration

Stuiver, M., et. al., 1998, Radiocarbon 40(3), p1041-1083

Mathe matics

A Simplified Approach to Calibrating C14 Dates

Talma, A. S., Vogel, J. C., 1993, Radiocarbon 35(2), p317-322

\section{Beta Analytic Inc.}

4985 SW 74 Court, Miami, Florida 33155 USA Pel: (305) 6675167 •Fax: (305) 6630964 • E-Mail: beta@ radiocarbon.com 


\title{
CALIBRATION OF RADIOCARBON AGE TO CALENDAR YEARS
}

\author{
(Variables: C13/C12=-25.7:1ab. mult =1) \\ Laboratory number: Beta-160816 \\ Conventional radiocarbon age: $2980 \pm 40$ BP \\ 2 Sigm a calibrated results: Cal BC 1360 to 1360 (Cal B P 3310 to 3300 ) and \\ (95\% probability) Cal BC 1320 to 1060 (Cal B P 3260 to 3000) \\ Intercept data
}

Intercept of radiocarbon age

with calibration curve:

Cal B C $1210($ Cal B P 3160$)$

1 Sigma calibrated result: Cal BC 1280 to 1130 (Cal BP 3230 to 3080 ) $(68 \%$ probability)

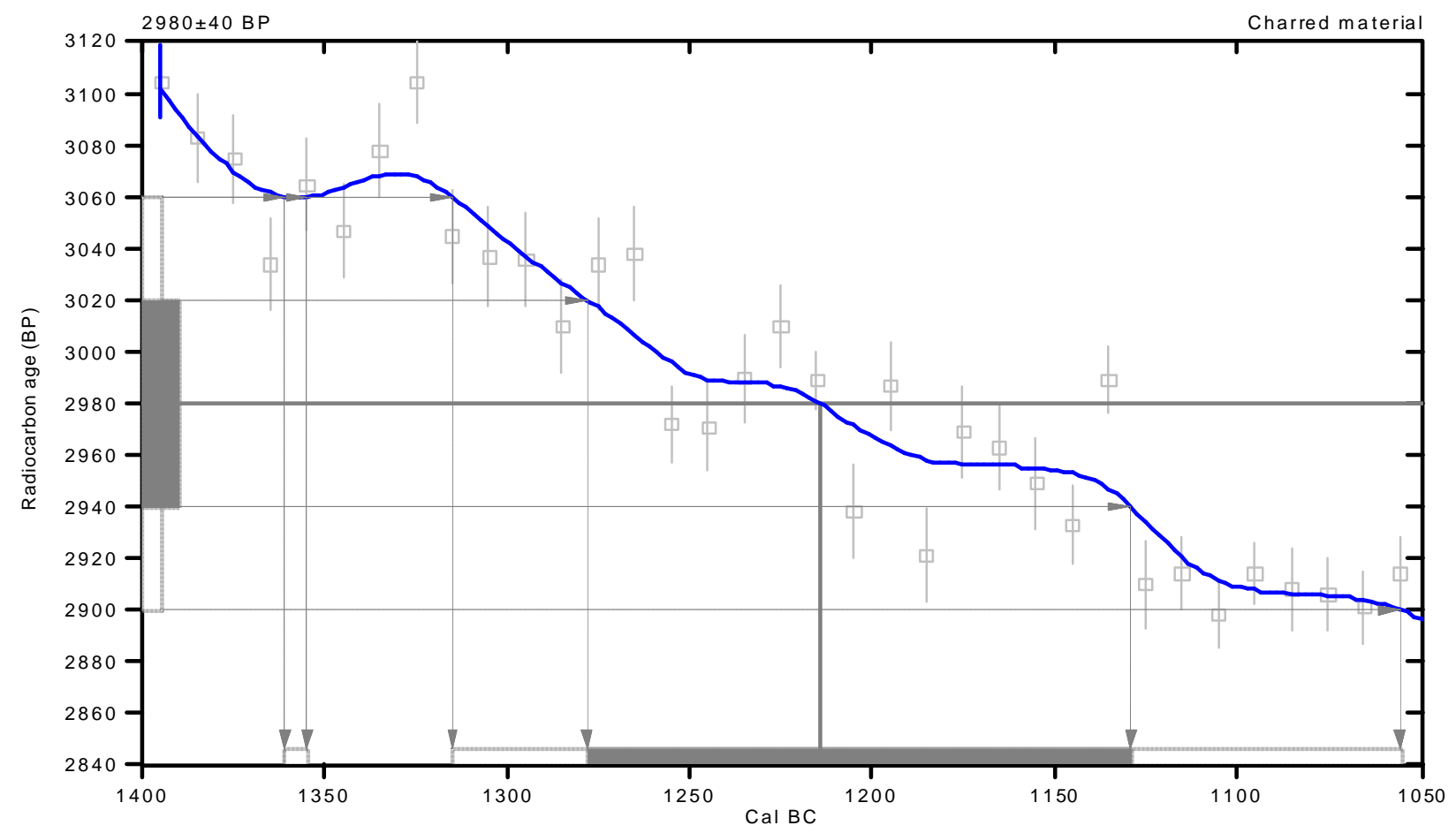

References :

Database used

Calibration Database

Editorial Com ment

Stuiver, M., van der Plicht, H., 1998, Radioca rbon 40(3), pxii-xiii

INTCAL98 Radiocarbon Age Calibration

Stuiver, M., et. al., 1998, Radiocarbon 40(3), p1041-1083

Mathematics

A Simplified Approach to Calibrating C14 Dates

Talma, A. S., Vogel, J. C., 1993, Radiocarbon 35(2), p317-322

\section{Beta Analytic Inc.}

4985 SW 74 Court, Miami, Florida 33155 USA • Tel: (305) $6675167 \cdot$ Fax: (305) $6630964 \cdot$ E-Mail: beta@ radiocarbon.com 


\section{CALIBRATION OF RADIOCARBON AGE TO CALENDAR YEARS}

(Variables: C $13 / \mathrm{C} 12=-24.4: 1 \mathrm{ab} . \mathrm{mult}=1$ )

Laboratory number: Beta-160817

Conventional radiocarbon age: $1210 \pm 50 \mathrm{BP}$

2 Sigm a calibrated result: Cal AD 690 to 960 (Cal BP 1260 to 990 ) (95\% probability)

Intercept data

Intercept of radiocarbon age

with calibration curve: Cal AD 790 (Cal B P 1160)

1 Sigma calibrated result: Cal AD 770 to 890 (Cal B P 1180 to 1060) (68\% probability)

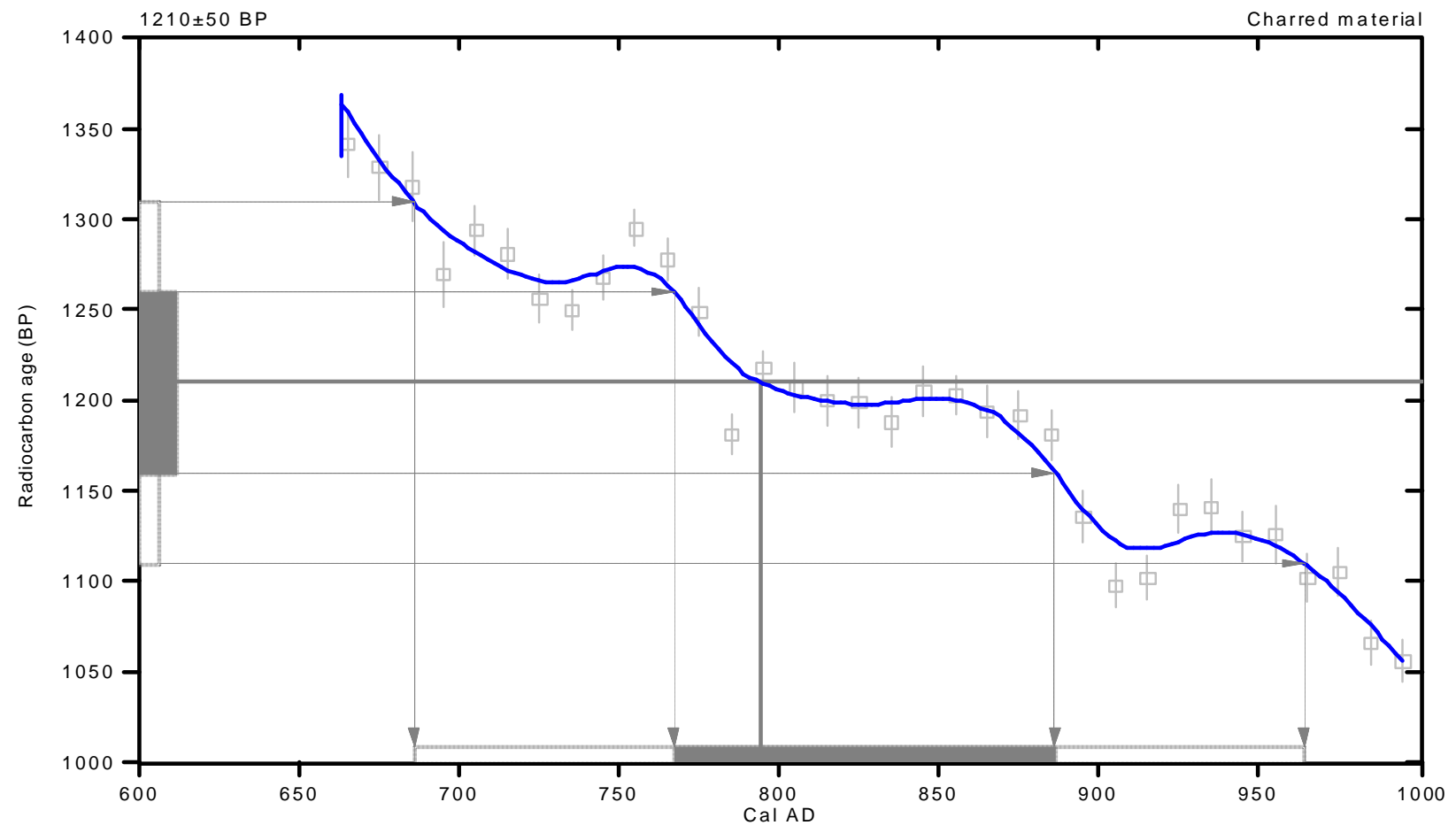

References:

Database used

Calibration Database

Editorial Com ment

Stuiver, M., van der Plicht, H., 1998, Radioca rbon 40(3), pxii-xiii

IN TCA L98 Radiocarbon Age Calibration

Stuiver, M., et. al., 1998, Radiocarbon 40(3), p1041-1083

Mathematics

A Simplified Approach to Calibrating C14 Dates

Talma, A. S., Vogel, J. C., 1993, Radiocarbon 3 5(2), p317-322

\section{Beta Analytic Inc.}

4985 SW 74 Court, Miami, Florida 33155 USA $・$ Tel: (305) $6675167 \cdot$ Fax: (305) $6630964 \cdot$ E-Mail: beta@ radiocarbon.com 


\section{CALIBRATION OF RADIOCARBON AGE TO CALENDAR YEARS}

(V ariables: C $13 / \mathrm{C} 12=-25.2: 1 \mathrm{ab} . \mathrm{mult}=1$ )

Laboratory number: Beta-160818

Conventional radiocarbon age: $\mathbf{7 9 0 \pm 4 0 ~ B P}$

2 Sigm a calibrated result: Cal AD 1180 to 1290 (Cal BP 760 to 660)

(95\% probability)

Intercept data

Intercept of radiocarbon age

with calibration curve: Cal AD 1260 (Cal B P 690)

1 Sigm a calibrated result: Cal AD 1220 to 1270 (Cal BP 730 to 680)

$(68 \%$ probability)

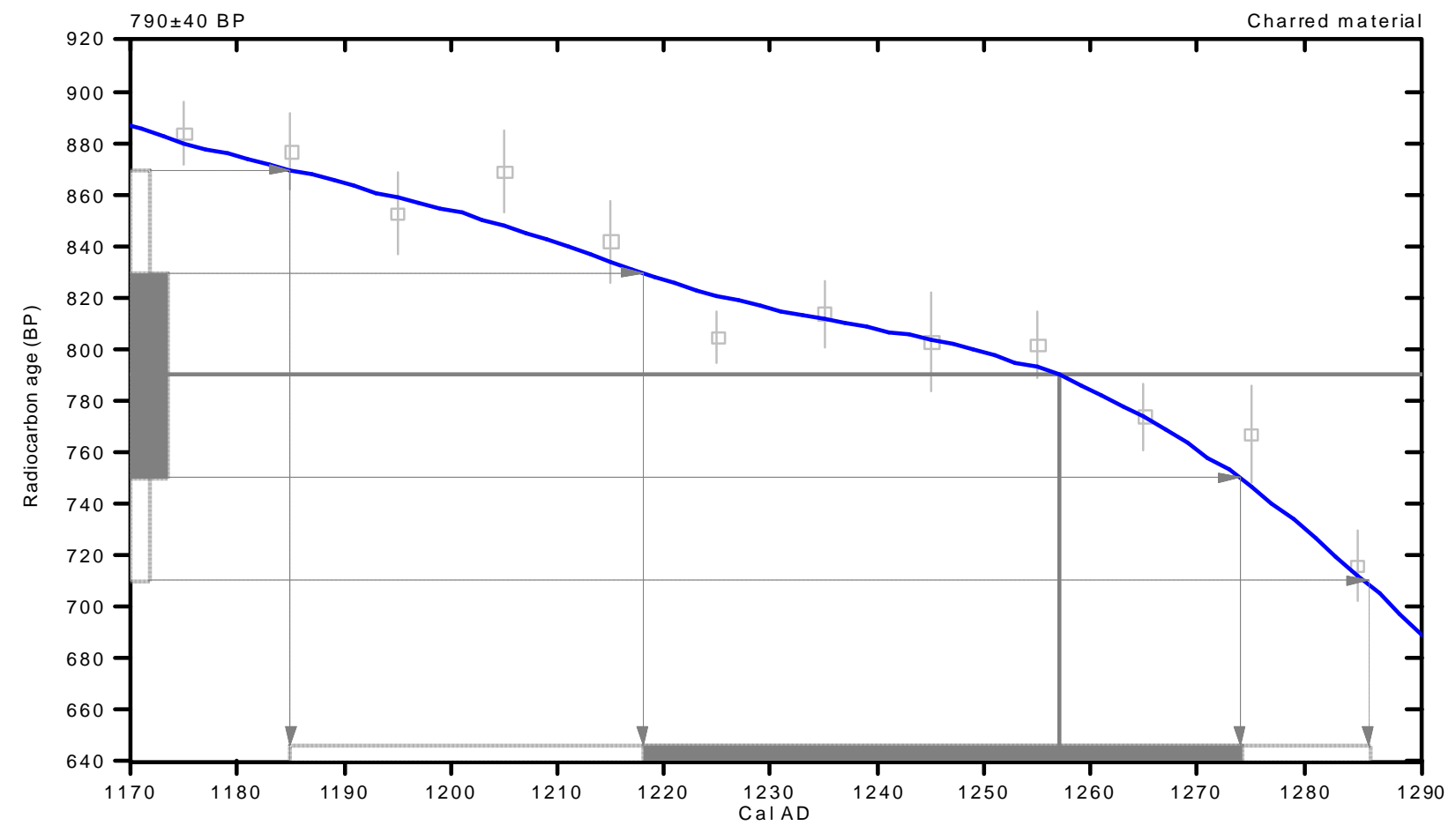

References :

Database used

Calibration Database

Editorial Com ment

Stuiver, M., van der Plicht, H., 1998, Radioca rbon 40(3), pxii-xiii

INTCAL98 Radiocarbon Age Calibration

Stuiver, M., et. al., 1998, Radiocarbon 40(3), p1041-1083

Mathematics

A Simplified Approach to Calibrating C14 Dates

Talma, A. S., Vogel, J. C., 1993, Radiocarbon 35(2), p317-322

\section{Beta Analytic Inc.}

4985 SW 74 Court, Miami, Florida 33155 USA • Tel: (305) $6675167 \cdot$ Fax: (305) $6630964 \cdot$ E-Mail: beta@ radiocarbon.com 


\section{CALIBRATION OF RADIOCARBON AGE TO CALENDAR YEARS}

(Variables: C13/C 12=-26.4:1ab. mult=1)

Laboratory number: Beta-160819

Conventional radiocarbon age: $730 \pm 40 \mathrm{BP}$

2 Sigm a calibrated result: Cal AD 1240 to 1300 (Cal BP 710 to 650) (95\% probability)

Intercept data

Intercept of radiocarbon age with calibration curve:

Cal AD $1280($ Cal BP 670$)$

1 Sigm a calibrated result: Cal AD 1270 to 1290 (Cal BP 680 to 660) (68\% probability)

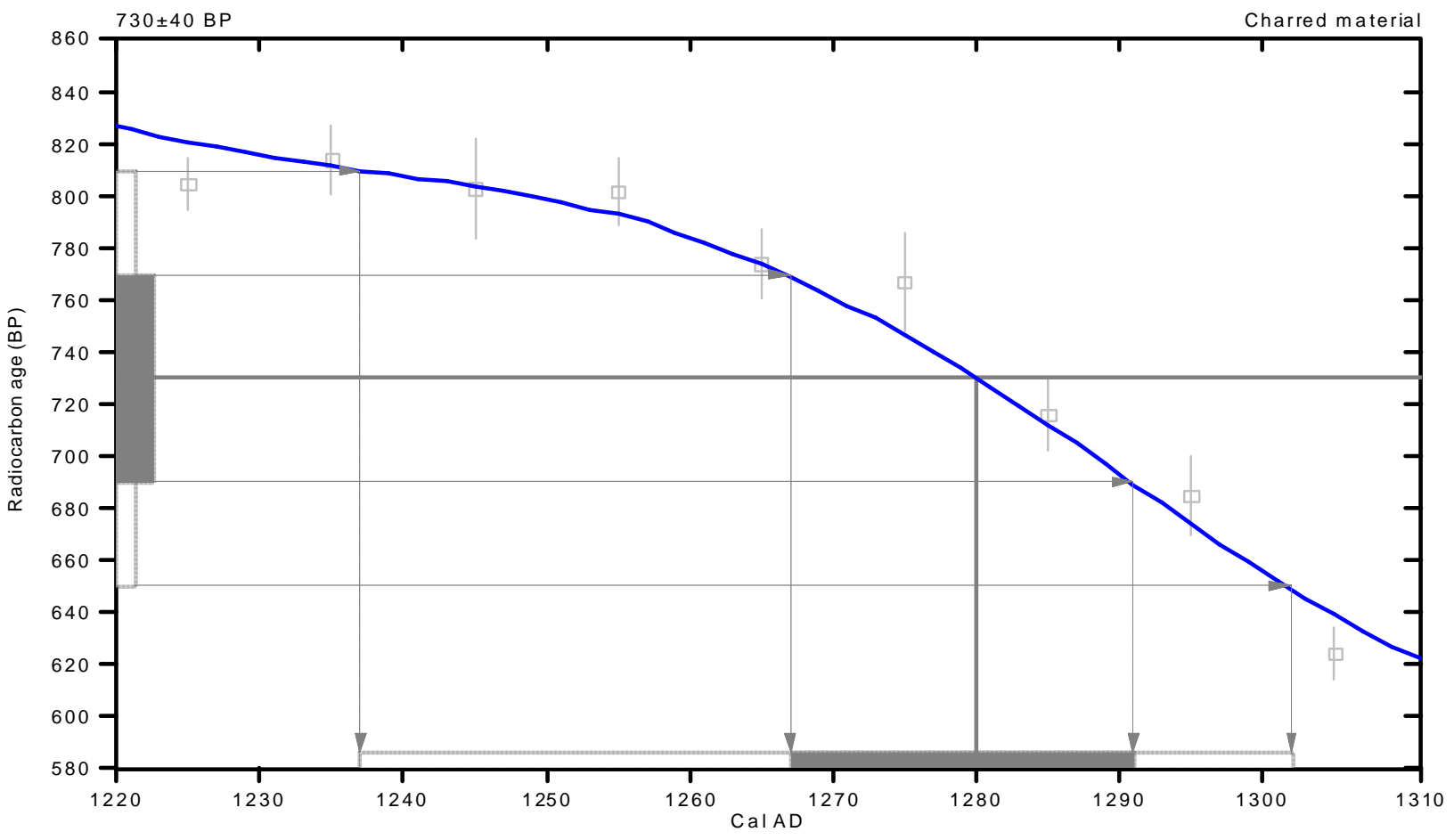

References:

Database used

Calibration Database Editorial Com ment

Stuiver, M., van der Plicht, H., 1998, Radioca rbon 40(3), pxii-xiii

IN TCA L98 Radiocarbon Age Calibration

Stuiver, M., et. al., 1998, Radiocarbon 40(3), p1041-1083

Mathematics

A Simplified Approach to Calibrating C14 Dates

Talma, A. S., Vogel, J. C., 1993, Radiocarbon 35(2), p317-322

\section{Beta Analytic Inc.}

4985 SW 74 Court, Miami, Florida 33155 USA $・$ Tel: (305) $6675167 \cdot$ Fax: (305) $6630964 \cdot$ E-Mail: beta@ radiocarbon.com 


\section{CALIBRATION OF RADIOCARBON AGE TO CALENDAR YEARS}

(V ariables: C $13 / \mathrm{C} 12=-26.2: 1 \mathrm{ab} . \mathrm{mult}=1$ )

Laboratory number: Beta-160820

Conventional radiocarbon age: $750 \pm 40$ BP

2 Sigm a calibrated result: Cal AD 1220 to 1300 (Cal BP 730 to 650 )

(95\% probability)

Intercept data

Intercept of radiocarbon age

with calibration curve: Cal AD 1270 (Cal B P 680)

1 Sigm a calibrated result: Cal AD 1260 to 1290 (Cal BP 690 to 660)

$(68 \%$ probability)

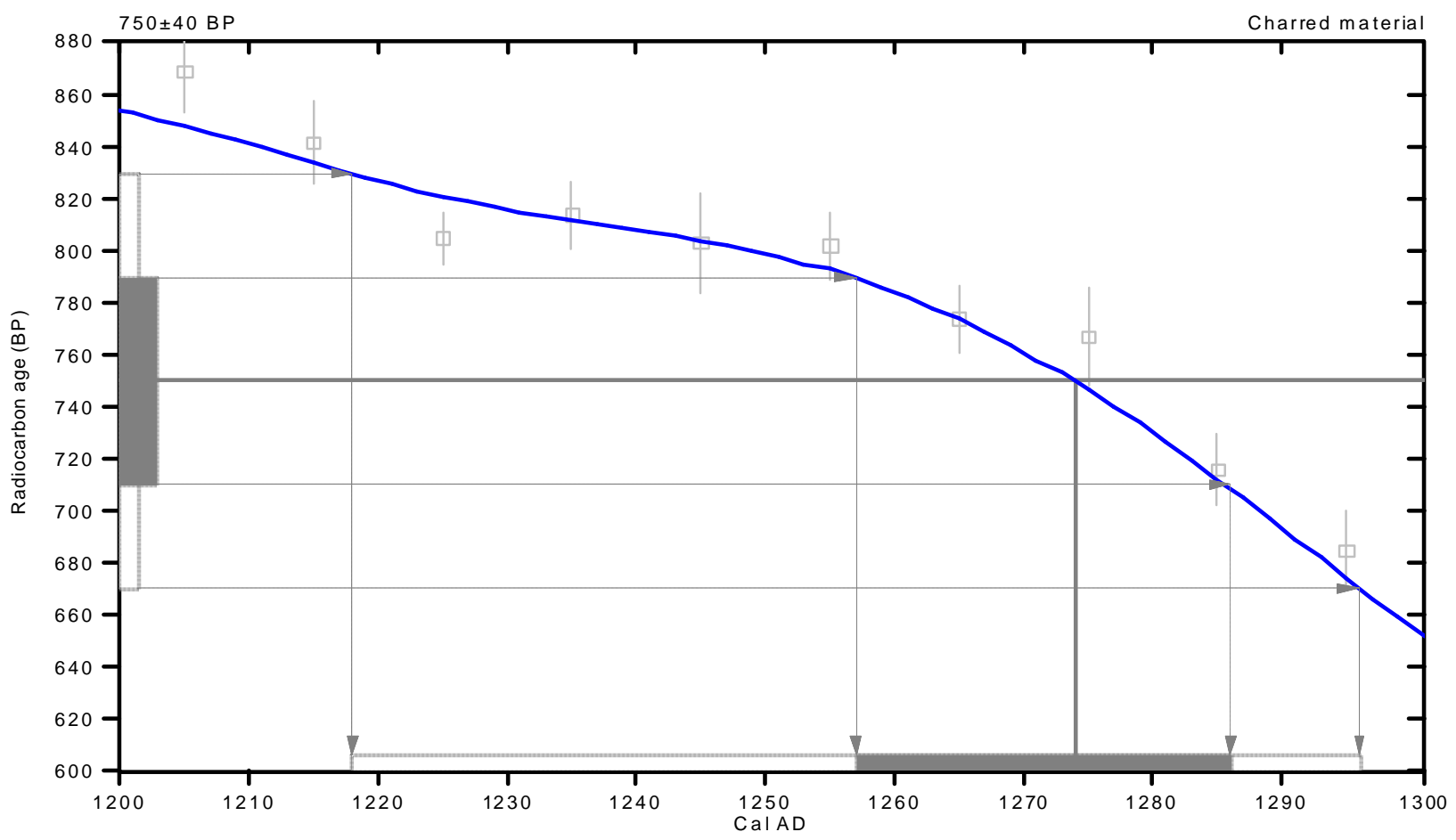

References:

Database used

Calibration Database

Editorial Com ment

Stuiver, M., van der Plicht, H., 1998, Radioca rbon 40(3), pxii-xiii

INTCAL98 Radiocarbon Age Calibration

Stuiver, M., et. al., 1998, Radiocarbon 40(3), p1041-1083

Mathematics

A Simplified Approach to Calibrating C14 Dates

Talma, A. S., Vogel, J. C., 1993, Radiocarbon 35(2), p317-322

\section{Beta Analytic Inc.}

4985 SW 74 Court, Miami, Florida 33155 USA • Tel: (305) $6675167 \cdot$ Fax: (305) $6630964 \cdot$ E-Mail: beta@ radiocarbon.com 


\section{CALIBRATION OF RADIOCARBON AGE TO CALENDAR YEARS}

(Variables: C $13 / \mathrm{C} 12=-25.2: 1 \mathrm{ab} . \mathrm{mult}=1$ )

Laboratory number: Beta-160821

Conventional radiocarbon age: $850 \pm 40 \mathrm{BP}$

2 Sigm a calibrated results: Cal AD 1050 to 1100 (Cal BP 900 to 850 ) and

(95\% probability) Cal AD 1140 to 1270 (Cal BP 810 to 680)

Intercept data

Intercept of radiocarbon age

with calibration curve: Cal AD 1200 (Cal B P 750)

1 Sigm a calibrated result: Cal AD 1170 to 1240 (Cal BP 780 to 710 )

(68\% probability)

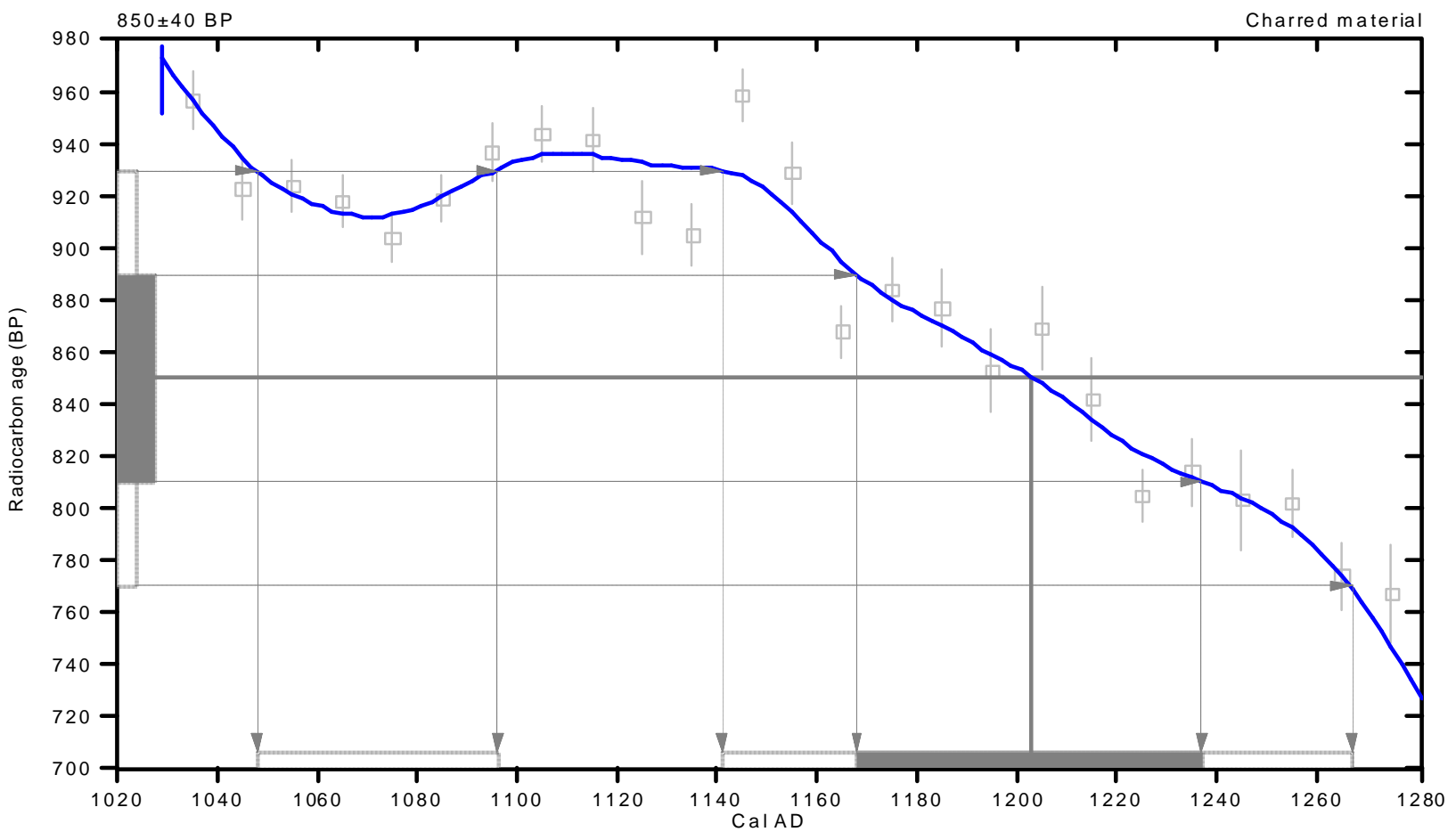

References:

Da tabase used

Calibration Database

Editorial Com ment

Stuiver, M., van der Plicht, H., 1998, Radioca rbon 40(3), pxii-xiii

IN TCA L98 Radiocarbon Age Calibration

Stuiver, M., et. al., 1998, Radiocarbon 40(3), p1041-1083

Mathe matics

A Simplified Approach to Calibrating C14 Dates

Talma, A. S., Vogel, J. C., 1993, Radiocarbon 35(2), p317-322

\section{Beta Analytic Inc.}

4985 SW 74 Court, Miami, Florida 33155 USA Pel: (305) 6675167 •Fax: (305) 6630964 • E-Mail: beta@ radiocarbon.com 


\section{CALIBRATION OF RADIOCARBON AGE TO CALENDAR YEARS}

(V ariables: C 13/C12=-25.1:1ab. mult=1)

Laboratory number: Beta-160822

Conventional radiocarbon age: $1120 \pm 40$ BP

2 Sigm a calibrated results: Cal AD 810 to 840 (Cal BP 1140 to 1110 ) and

(95\% probability) Cal AD 860 to 1000 (Cal BP 1100 to 950)

Intercept data

Intercepts of radiocarbon age

with calibration curve: Cal AD 910 (Cal B P 1040) and

Cal AD 920 (Cal BP 1030) and

Cal AD 960 (Cal BP 1000 )

1 Sigma calibrated result: Cal AD 890 to 980 (Cal B P 1060 to 970) (68\% probability)

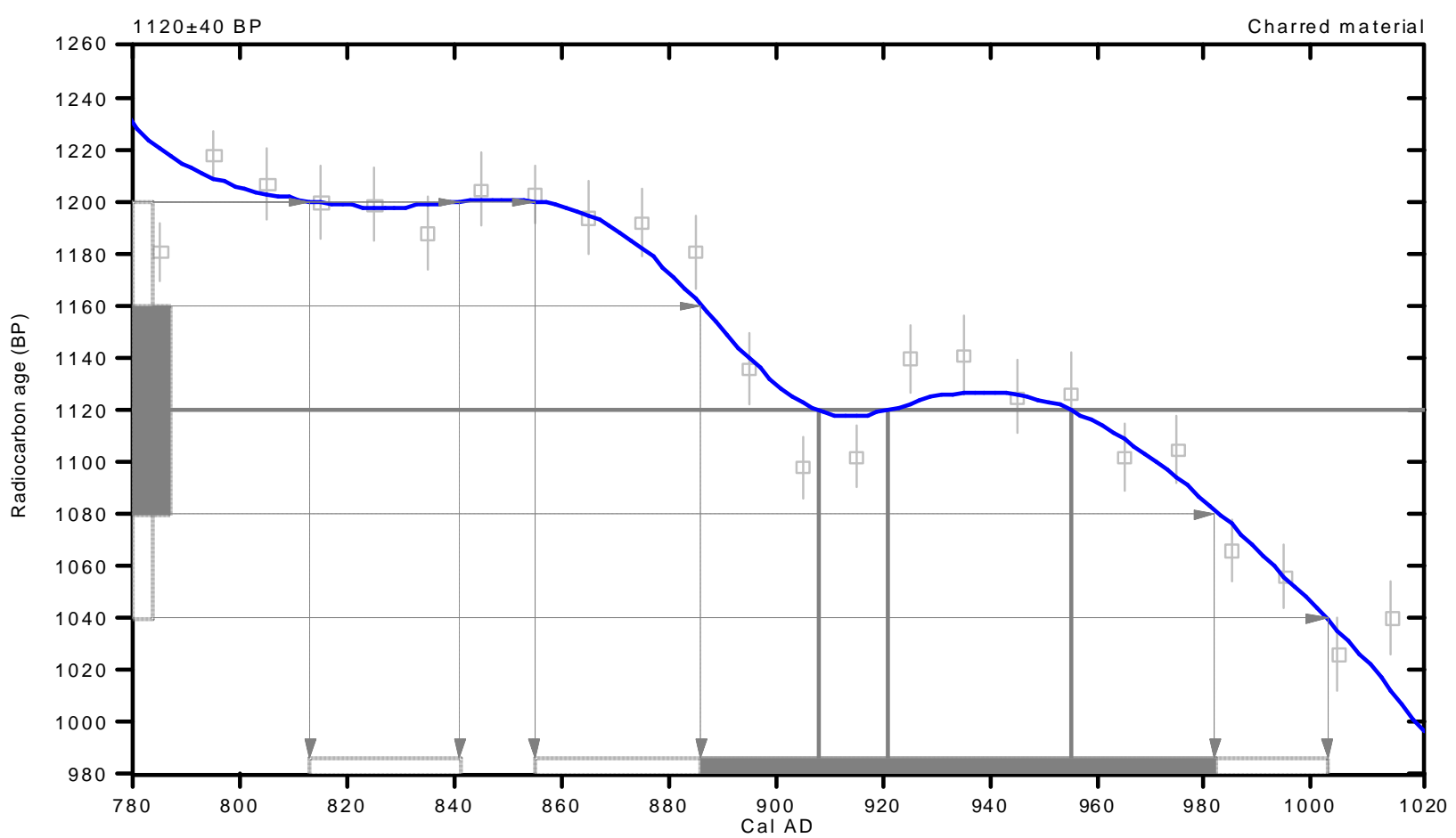

References :

Database used

Calibration Database

Editorial Com ment

Stuiver, M., van der Plicht, H., 1998, Radioca rbon 40(3), pxii-xiii

INTCA L98 Radiocarbon Age Calibration

Stuiver, M., et. al., 1998, Radiocarbon 40(3), p1041-1083

Mathe matics

A Simplified Approach to Calibrating C14 Dates

Talma, A. S., Vogel, J. C., 1993, Radiocarbon 35(2), p317-322

\section{Beta Analytic Inc.}

4985 SW 74 Court, Miami, Florida 33155 USA •Tel: (305) 6675167 • Fax: (305) 6630964 •E-Mail: beta@ radiocarbon.com 


\section{CALIBRATION OF RADIOCARBON AGE TO CALENDAR YEARS}

(Variables: C $13 / \mathrm{C} 12=-25.5: 1 \mathrm{ab} . \mathrm{mult}=1$ )

\section{Laboratory number: Beta-161946}

Conventional radiocarbon age: $210 \pm 40 \mathrm{BP}$

2 Sigm a calibrated results: Cal AD 1640 to 1690 (Cal BP 310 to 260) and (95\% probability) Cal AD 1730 to 1810 (Cal BP 220 to 140) and Cal AD 1920 to 1950 (Cal BP 30 to 0)

Intercept data

Intercept of radiocarbon age with calibration curve:

1 Sigm a calibrated results: (68\% probability)
Cal AD 1660 (Cal BP 290)

Cal AD 1650 to 1680 (Cal BP 300 to 270) and Cal AD 1770 to 1800 (Cal BP 180 to 150 ) and Cal AD 1940 to 1950 (Cal BP 10 to 0)

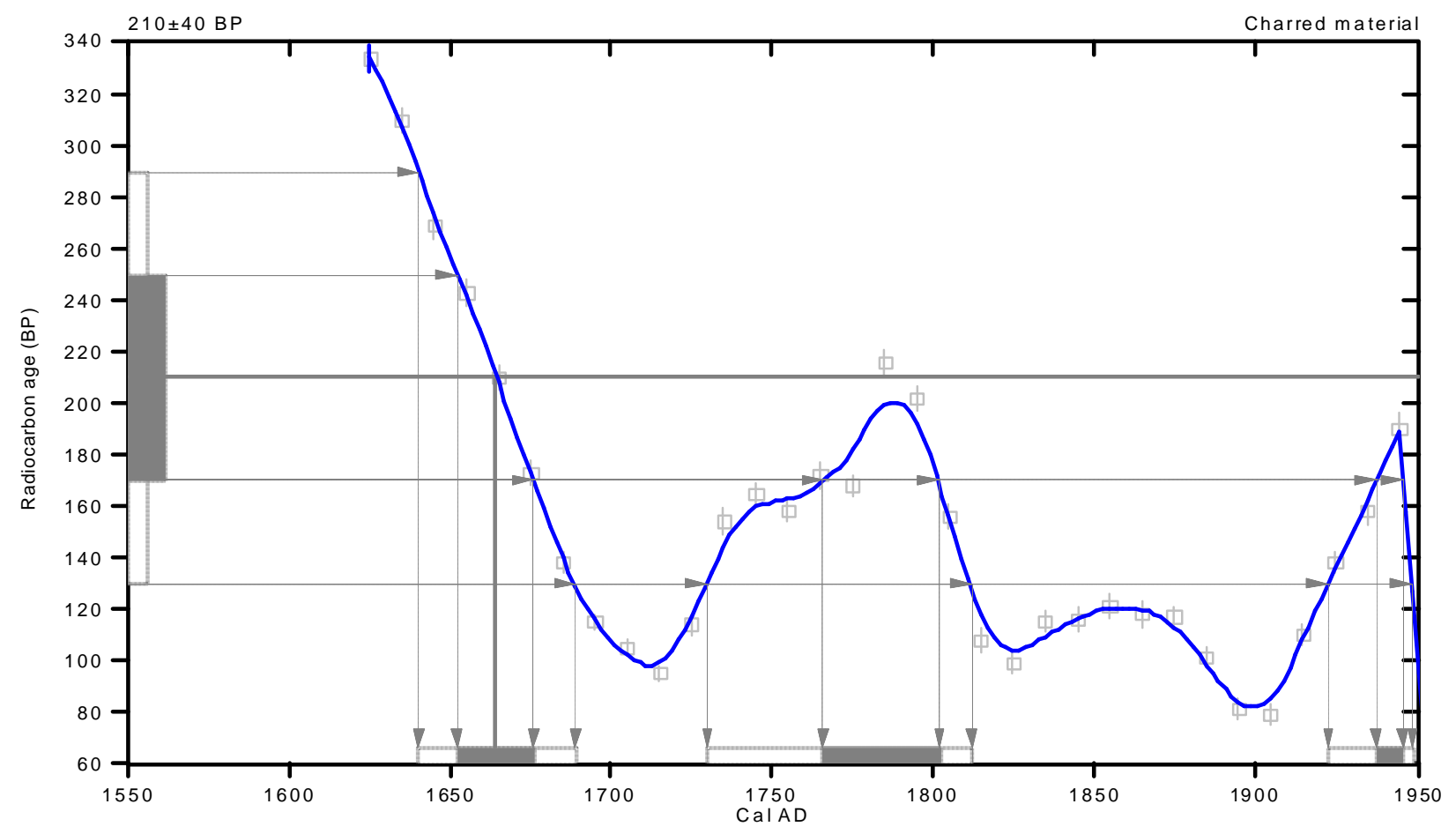

References:

Database used

Calibration Database Editorial Com ment

Stuiver, M., van der Plicht, H., 1998, Radioca rbon 40(3), pxii-xiii

IN TCA L98 Radiocarbon Age Calibration

Stuiver, M., et. al., 1998, Radiocarbon 40(3), p1041-1083

Mathe matics

A Simplified Approach to Calibrating C14 Dates

Talma, A. S., Vogel, J. C., 1993, Radiocarbon 35(2), p317-322

\section{Beta Analytic Inc.}

4985 SW 74 Court, Miami, Florida 33155 USA Pel: (305) 6675167 •Fax: (305) 6630964 • E-Mail: beta@ radiocarbon.com 


\title{
CALIBRATION OF RADIOCARBON AGE TO CALENDAR YEARS
}

\author{
(Variables: C13/C12=-25.6:1ab. mult $=1$ ) \\ Laboratory number: Beta-161947 \\ Conventional radiocarbon age: $880 \pm 40 \mathrm{BP}$ \\ 2 Sigm a calibrated result: Cal AD 1030 to 1250 (Cal BP 920 to 700 ) \\ (95\% probability) \\ Intercept data \\ Intercept of radiocarbon age \\ with calibration curve: Cal AD 1180 (Cal B P 780) \\ 1 Sigma calibrated results: Cal AD 1060 to 1080 (Cal BP 890 to 860) and \\ (68\% probability) Cal AD 1150 to 1210 (Cal BP 800 to 740)
}

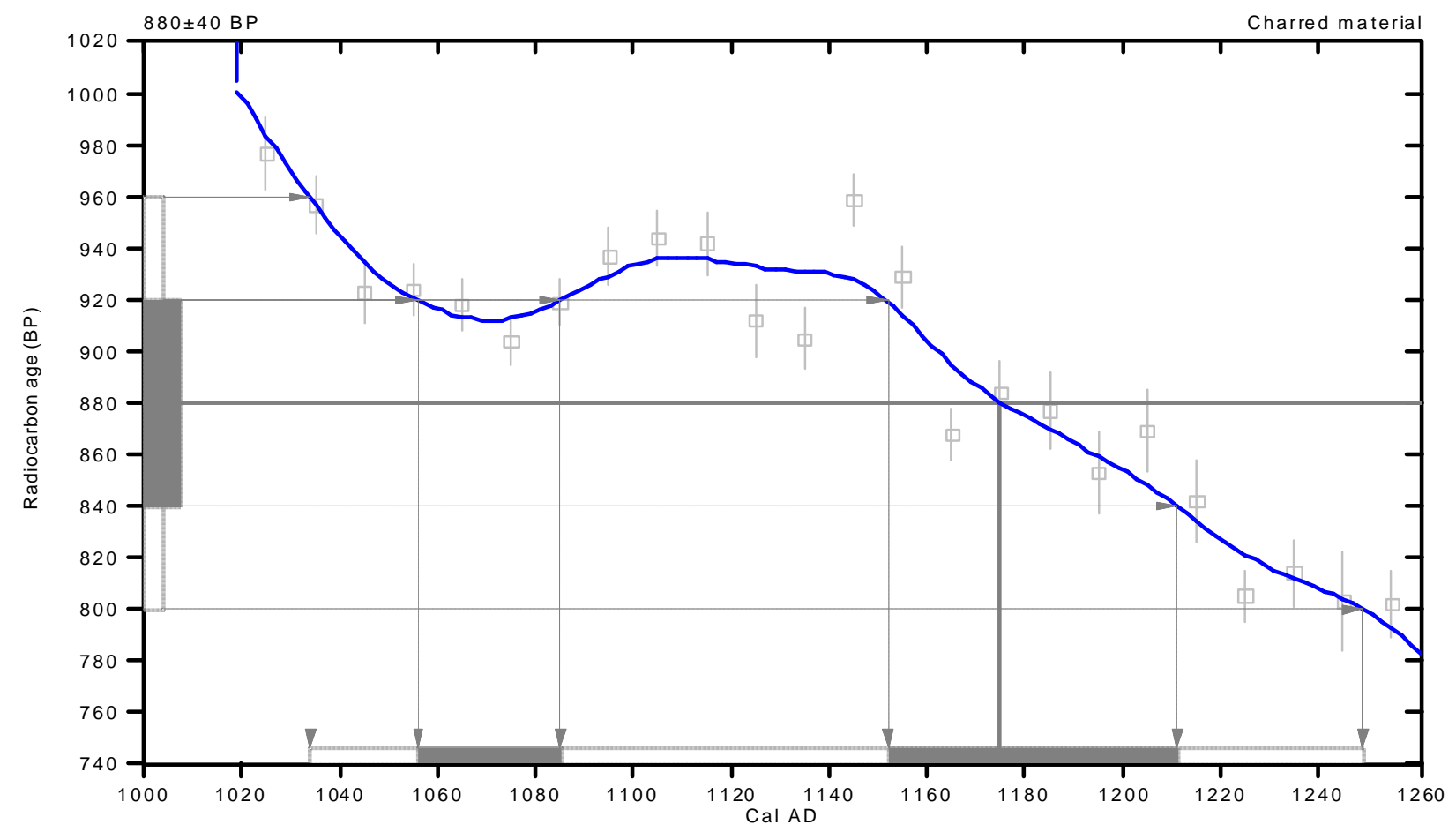

References:

Database used

Calibration Database

Editorial Com ment

Stuiver, M., van der Plicht, H., 1998, Radioca rbon 40(3), pxii-xiii

INTCA L98 Radiocarbon Age Calibration

Stuiver, M., et. al., 1998, Radiocarbon 40(3), p1041-1083

$M$ athe matics

A Simplified Approach to Calibrating C14 Dates

Talma, A.S., Vogel, J. C., 1993, Radiocarbon 35(2), p317-322

\section{Beta Analytic Inc.}

4985 SW 74 Court, Miami, Florida 33155 USA • Tel: (305) $6675167 \cdot$ Fax: (305) $6630964 \cdot$ E-Mail: beta@ radiocarbon.com 


\section{CALIBRATION OF RADIOCARBON AGE TO CALENDAR YEARS}

(Variables: C13/C 12=-24.9:1ab. mult=1)

\section{Laboratory number: Beta-161948}

Conventional radiocarbon age: $970 \pm 40 \mathrm{BP}$

2 Sigm a calibrated result: Cal AD 1000 to 1170 (Cal BP 950 to 780 ) (95\% probability)

Intercept data

Intercept of radiocarbon age with calibration curve:

Cal AD $1030($ Cal B P 920)

1 Sigma calibrated results: Cal AD 1020 to 1050 (Cal BP 930 to 900) and (68\% probability) Cal AD 1100 to 1140 (Cal BP 850 to 810$)$

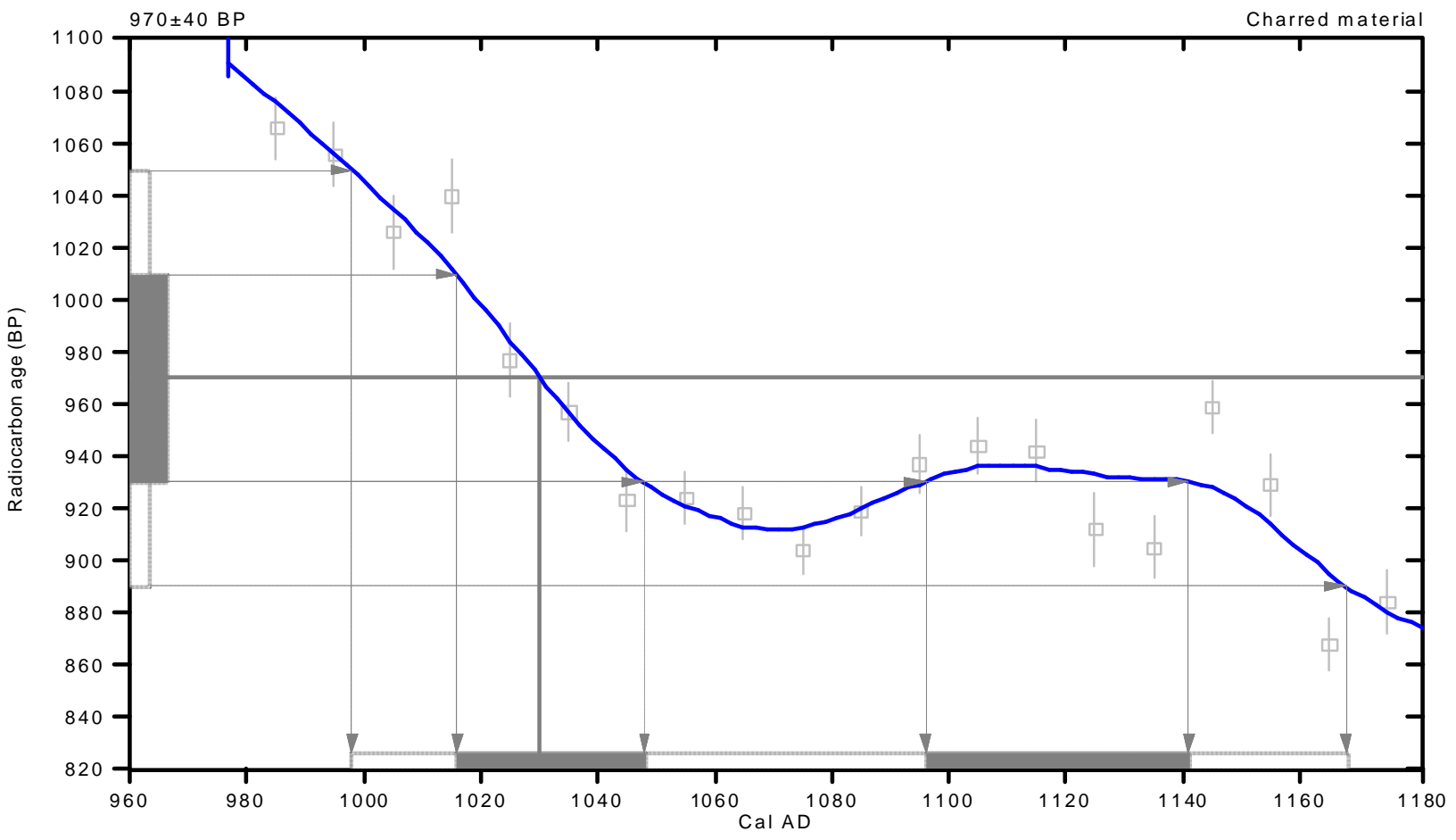

References:

Database used

Calibration Database Editorial Com ment

Stuiver, M., van der Plicht, H., 1998, Ra dioca rbon 40(3), pxii-xiii

IN TCA L98 Radiocarbon Age Calibration

Stuiver, M., et. al., 1998, Radiocarbon 40(3), p1041-1083

Mathematics

A Simplified Approach to Calibrating C14 Dates

Talma, A. S., Vogel, J. C., 1993, Radiocarbon 3 5(2), p317-322

\section{Beta Analytic Inc.}

4985 SW 74 Court, Miami, Florida 33155 USA $・$ Tel: (305) $6675167 \cdot$ Fax: (305) $6630964 \cdot$ E-Mail: beta@ radiocarbon.com 


\section{CALIBRATION OF RADIOCARBON AGE TO CALENDAR YEARS}

(V ariables: C 13/C12=-22.7:1ab. mult=1)

Laboratory number: Beta-161949

Conventional radiocarbon age: $650 \pm 40 \mathrm{BP}$

2 Sigm a calibrated result: Cal AD 1280 to 1400 (Cal BP 670 to 550)

(95\% probability)

Intercept data

Intercept of radiocarbon age

with calibration curve:

Cal AD 1300 (Cal BP 650)

1 Sigma calibrated results: Cal AD 1290 to 1320 (Cal BP 660 to 630) and

(68\% probability) Cal AD 1350 to 1390 (Cal BP 600 to 560)

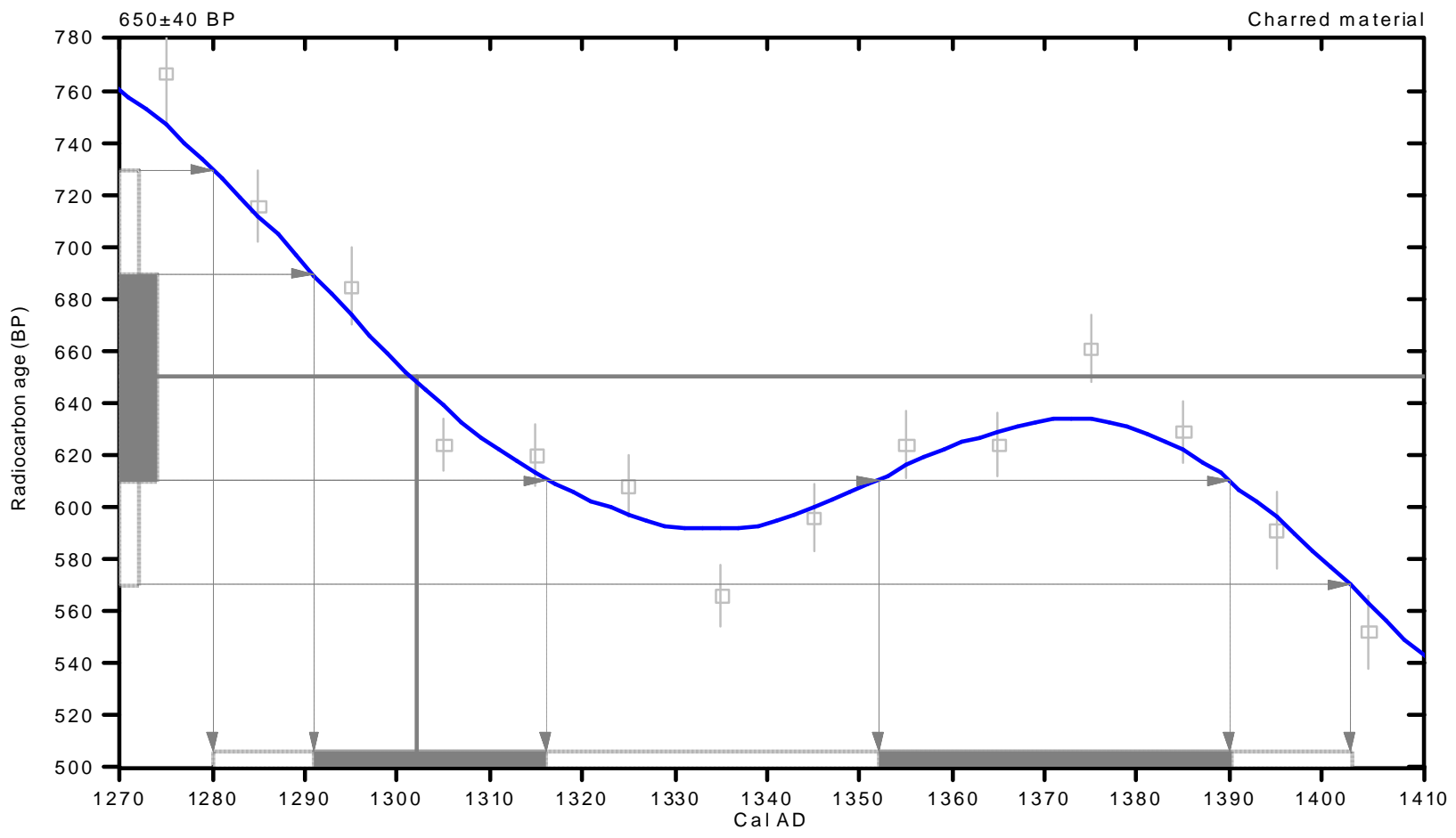

References :

Database used

Calibration Databa se

Editorial Com ment

Stuiver, M., van der Plicht, H., 1998, Radioca rbon 40(3), pxii-xiii

INTCAL98 Radiocarbon Age Calibration

Stuiver, M., et. al., 1998, Radiocarbon 40(3), p1041-1083

Mathematics

A Simplified Approach to Calibrating C14 Dates

Talma, A. S., Vogel, J. C., 1993, Radiocarbon 3 5(2), p317-322

\section{Beta Analytic Inc.}

4985 SW 74 Court, Miami, Florida 33155 USA • Tel: (305) $6675167 \cdot$ Fax: (305) $6630964 \cdot$ E-Mail: beta@ radiocarbon.com 


\section{CALIBRATION OF RADIOCARBON AGE TO CALENDAR YEARS}

(Variables: C13/C12=-22.7:1ab. mult=1)

Laboratory number: Beta-161950

Conventional radiocarbon age: $860 \pm 40 \mathrm{BP}$

2 Sigm a calibrated result: Cal AD 1040 to 1260 (Cal BP 910 to 690)

(95\% probability)

Intercept data

Intercept of radiocarbon age

with calibration curve: Cal AD 1190 (Cal BP 760)

1 Sigma calibrated result: Cal AD 1160 to 1230 (Cal BP 790 to 720 )

(68\% probability)

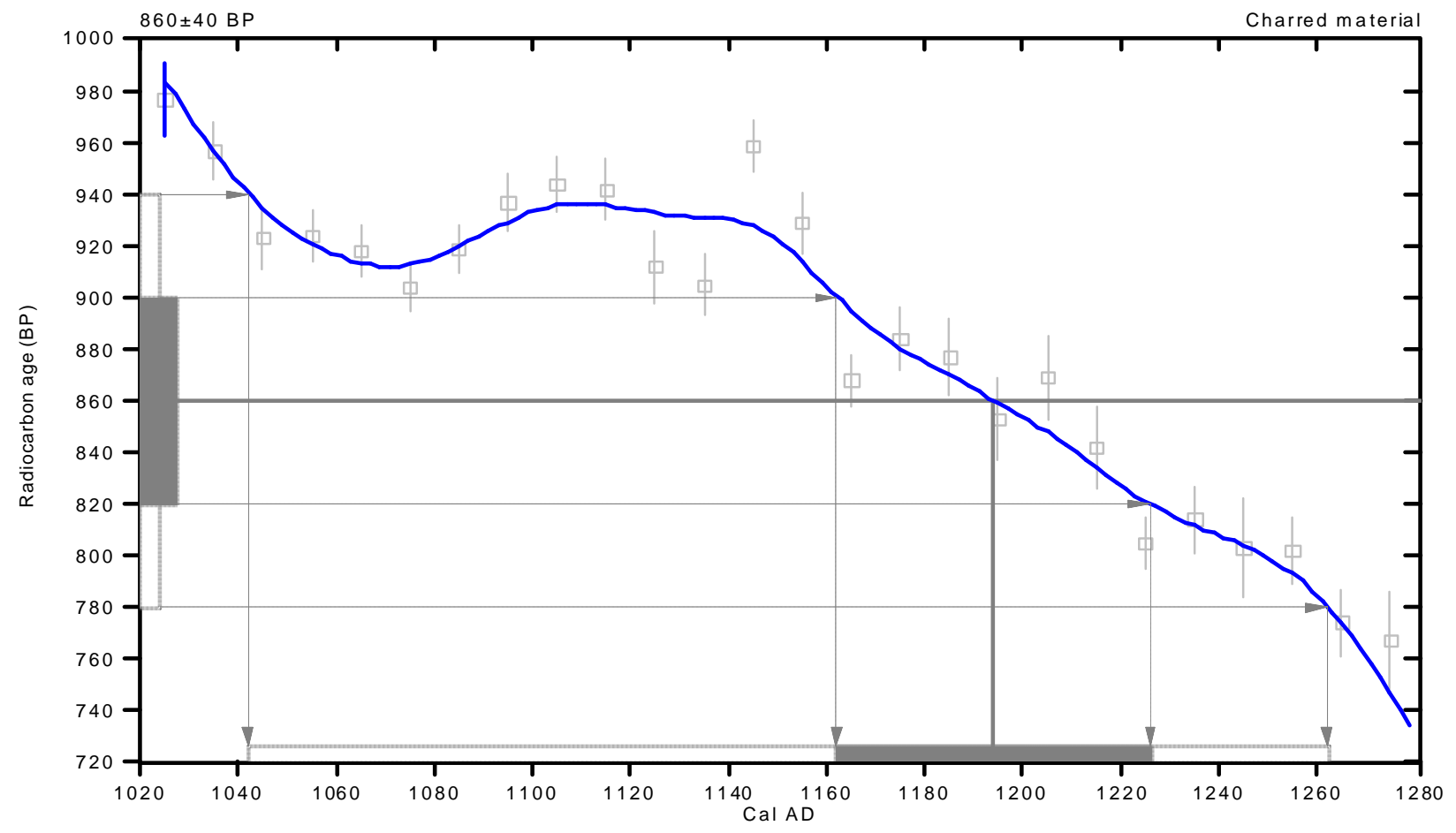

References:

Database used

Calibration Database

Editorial Com ment

Stuiver, M., van der Plicht, H., 1998, Radioca rbon 40(3), pxii-xiii

INTCAL98 Radiocarbon Age Calibration

Stuiver, M., et. al., 1998, Radiocarbon 40(3), p1041-1083

Mathe matics

A Simplified Approach to Calibrating C14 Dates

Talma, A. S., Vogel, J. C., 1993, Radiocarbon 35(2), p317-322

\section{Beta Analytic Inc.}

4985 SW 74 Court, Miami, Florida 33155 USA Pel: (305) 6675167 •Fax: (305) 6630964 • E-Mail: beta@ radiocarbon.com 


\title{
CALIBRATION OF RADIOCARBON AGE TO CALENDAR YEARS
}

\author{
(Variables: C13/C 12=-25.5:1ab. mult $=1$ ) \\ Laboratory number: Beta-161951 \\ Conventional radiocarbon age: $1000 \pm 40 \mathrm{BP}$ \\ 2 Sigm a calibrated results: Cal AD 980 to 1060 (Cal BP 970 to 890 ) and \\ (95\% probability) Cal AD 1080 to 1150 (Cal BP 860 to 800) \\ Intercept data
}

Intercept of radiocarbon age

with calibration curve:

Cal AD 1020 (Cal BP 930)

1 Sigm a calibrated result: Cal AD 1000 to 1030 (Cal BP 950 to 920)

(68\% probability)

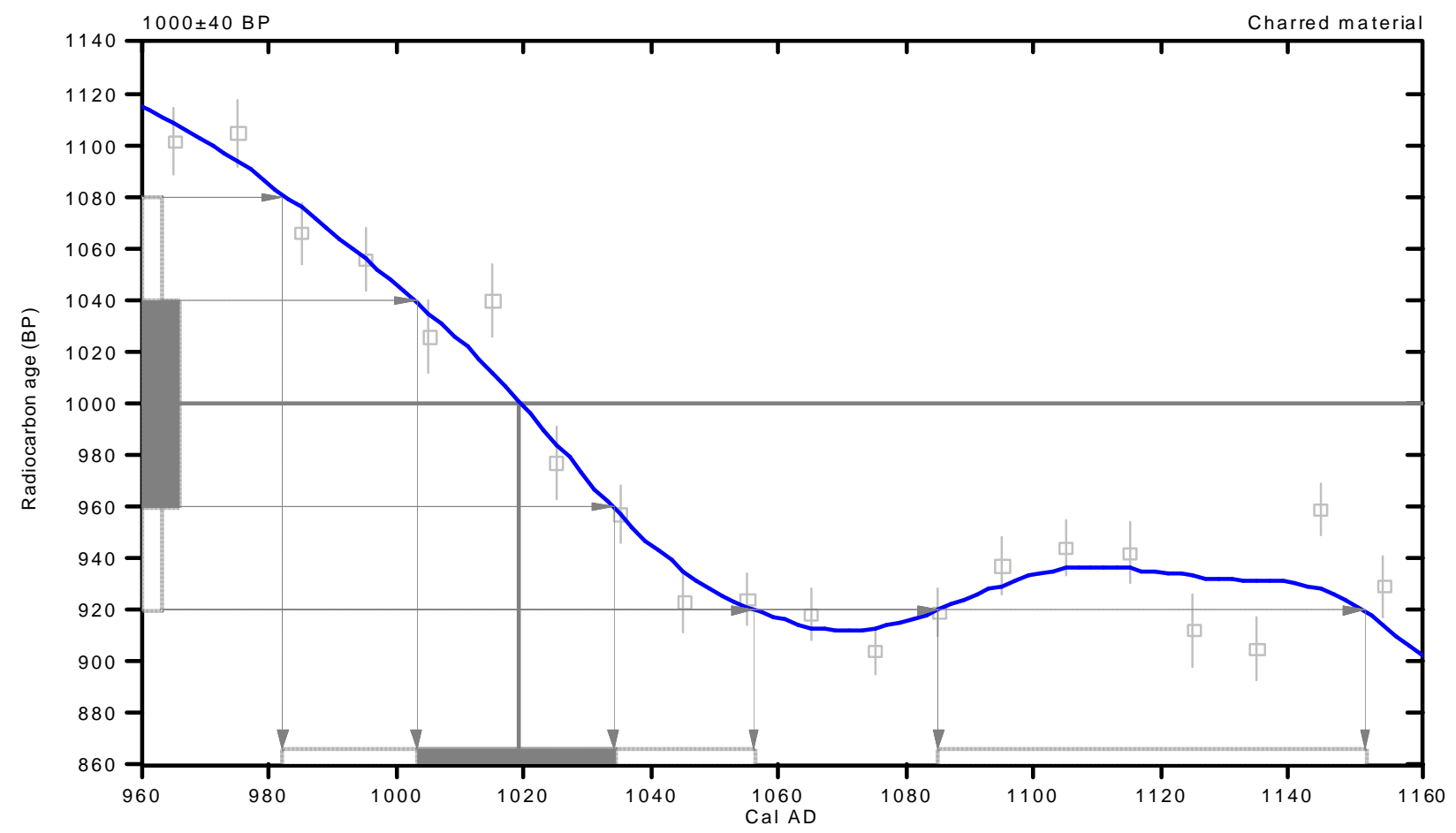

References :

Database used

Calibration Database

Editorial Com ment

Stuiver, M., van der Plicht, H., 1998, Radioca rbon 40(3), pxii-xiii

INTCAL98 Radiocarbon Age Calibration

Stuiver, M., et. al., 1998, Radiocarbon 40(3), p1041-1083

$M$ athematics

A Simplified Approach to Calibrating C14 Dates

Talma, A. S., Vogel, J. C., 1993, Radiocarbon 35(2), p317-322

\section{Beta Analytic Inc.}

4985 SW 74 Court, Miami, Florida 33155 USA • Tel: (305) $6675167 \cdot$ Fax: (305) $6630964 \cdot$ E-Mail: beta@ radiocarbon.com 


\section{CALIBRATION OF RADIOCARBON AGE TO CALENDAR YEARS}

(Variables: C13/C12=-24.7:1ab. mult=1)

Laboratory number: Beta-161952

Conventional radiocarbon age: $1170 \pm 40 \mathrm{BP}$

2 Sigm a calibrated result: Cal AD 770 to 980 (Cal BP 1180 to 970 ) (95\% probability)

Intercept data

Intercept of radiocarbon age with calibration curve:

Cal AD $880($ Cal BP 1070)

1 Sigm a calibrated result: Cal AD 790 to 900 (Cal B P 1160 to 1050) (68\% probability)

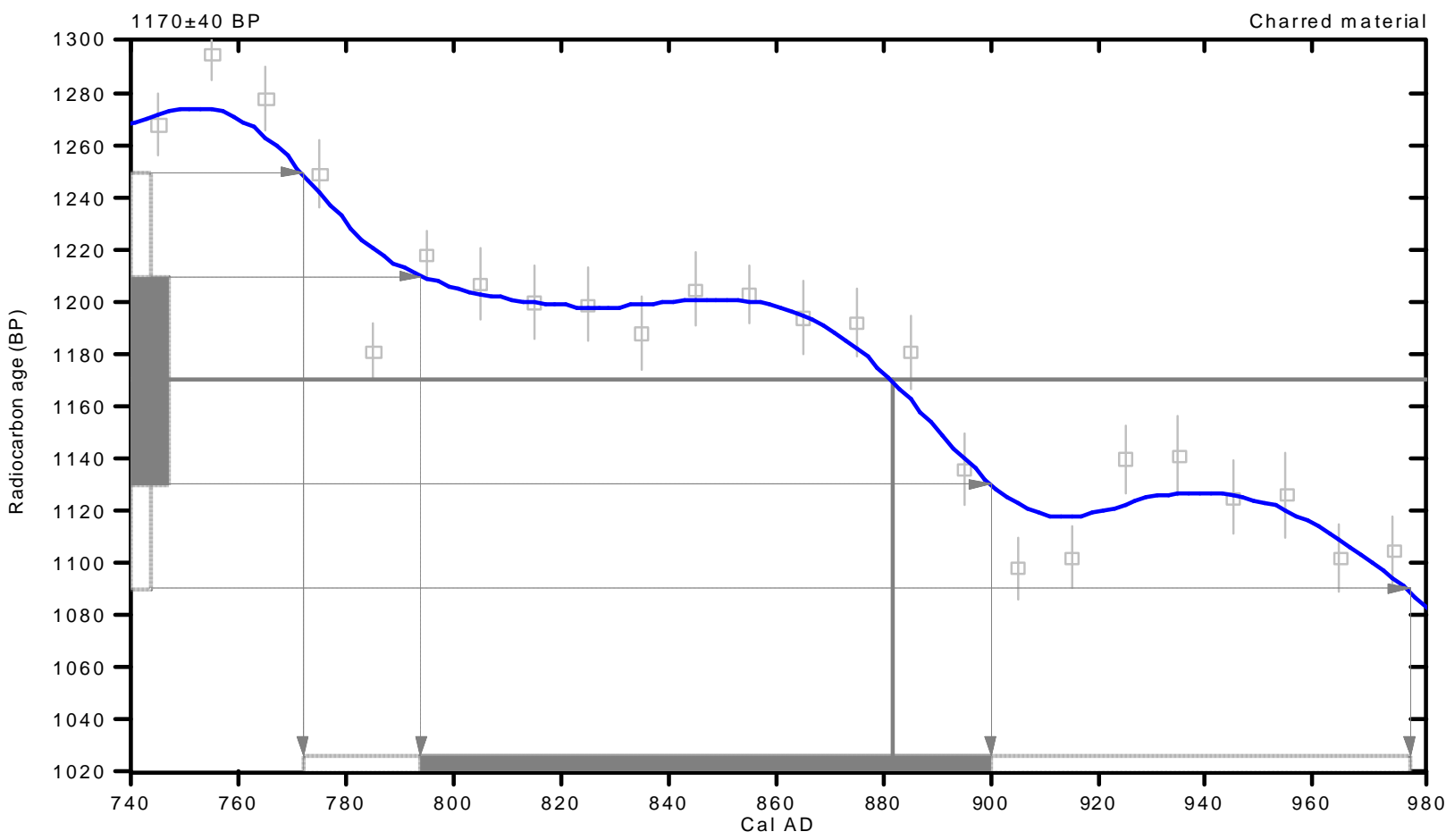

References:

Database used

Calibration Database Editorial Com ment

Stuiver, M., van der Plicht, H., 1998, Radioca rbon 40(3), pxii-xiii

INTCA L98 Radiocarbon Age Calibration

Stuiver, M., et. al., 1998, Radiocarbon 40(3), p1041-1083

Mathe matics

A Simplified Approach to Calibrating C14 Dates

Talma, A. S., Vogel, J. C., 1993, Radiocarbon 3 5(2), p317-322

\section{Beta Analytic Inc.}

4985 SW 74 Court, Miami, Florida 33155 USA $・$ Tel: (305) $6675167 \cdot$ Fax: (305) $6630964 \cdot$ E-Mail: beta@ radiocarbon.com 


\title{
CALIBRATION OF RADIOCARBON AGE TO CALENDAR YEARS
}

\author{
$\frac{\text { (Variables: } \mathrm{C} 13 / \mathrm{C} 12=-23.3: 1 \mathrm{ab} . \mathrm{mult}=1)}{\text { (V) }}$ \\ Laboratory number: Beta-161953 \\ Conventional radiocarbon age: $1160 \pm 40 \mathrm{BP}$ \\ 2 Sigm a calibrated result: Cal AD 780 to 980 (Cal BP 1170 to 970 ) \\ (95\% probability) \\ Intercept data \\ Intercept of radiocarbon age \\ with calibration curve: \\ Cal AD $890($ Cal B P 1060) \\ 1 Sigma calibrated results: Cal AD 810 to 840 (Cal B P 1140 to 1110) and \\ (68\% probability) Cal AD 860 to 910 (Cal B P 1100 to 1040) and \\ Cal AD 920 to 960 (Cal B P 1030 to 1000)
}

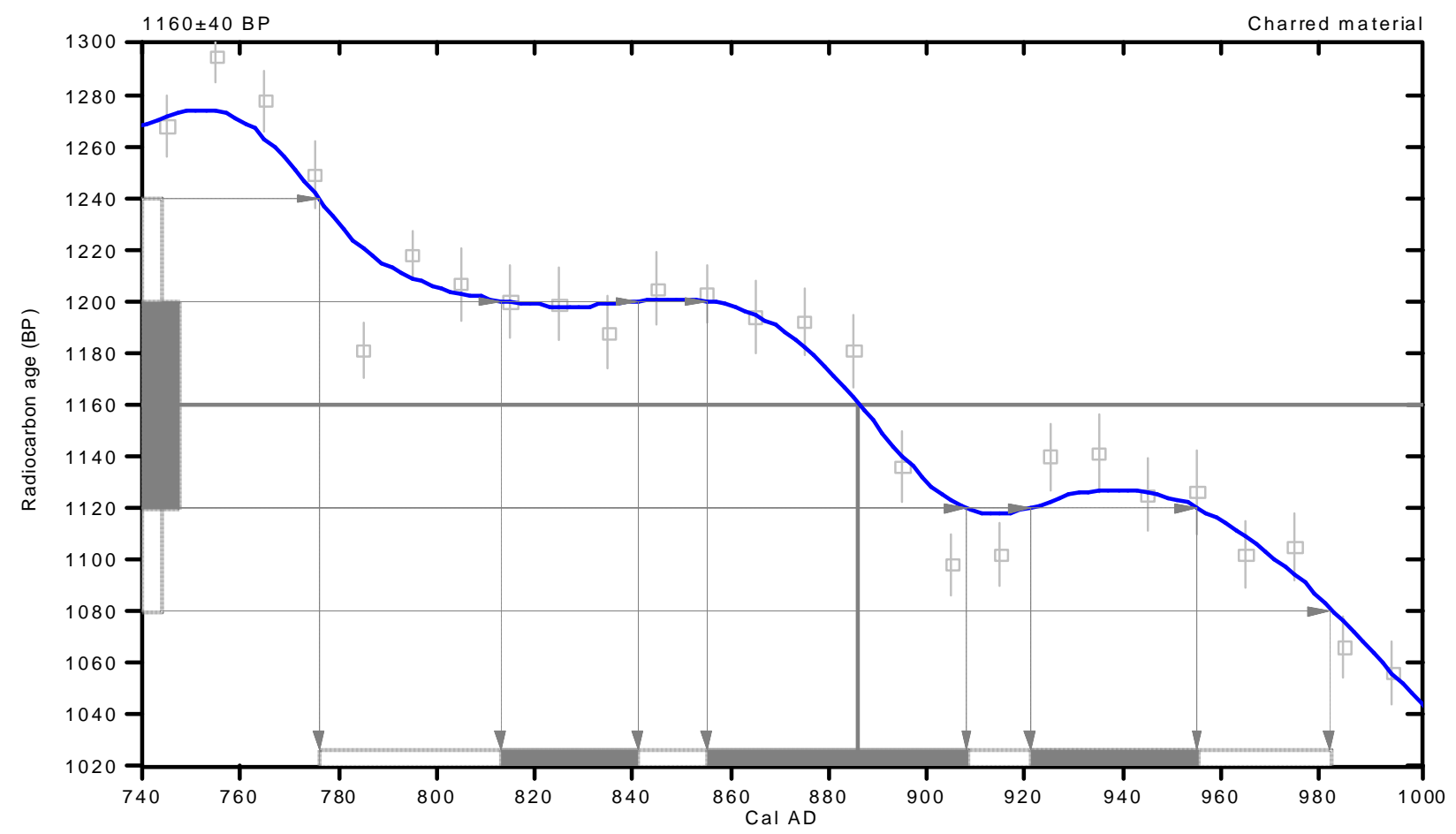

References:

Database used

Calibration Database

Editorial Com ment

Stuiver, M., van der Plicht, H., 1998, Radioca rbon 40(3), pxii-xiii

INTCAL98 Radiocarbon Age Calibration

Stuiver, M., et. al., 1998, Radiocarbon 40(3), p1041-1083

$M$ athe matics

A Simplified Approach to Calibrating C14 Dates

Talma, A. S., Vogel, J. C., 1993, Radiocarbon 3 5(2), p317-322

\section{Beta Analytic Inc.}

4985 SW 74 Court, Miami, Florida 33155 USA • Tel: (305) $6675167 \cdot$ Fax: (305) 6630964 •E-Mail: beta@ radiocarbon.com 


\section{CALIBRATION OF RADIOCARBON AGE TO CALENDAR YEARS}

(Variables: C $13 / \mathrm{C} 12=-25.3: 1 \mathrm{ab} . \mathrm{mult}=1$ )

Laboratory number: Beta-161954

Conventional radiocarbon age: $2830 \pm 40$ BP

2 Sigm a calibrated result: Cal BC 1100 to 900 (Cal BP 3050 to 2850)

(95\% probability)

Intercept data

Intercept of radiocarbon age

with calibration curve: Cal B C 990 (Cal B P 2940)

1 Sigma calibrated result: Cal BC 1020 to 920 (Cal B P 2970 to 2870) (68\% probability)

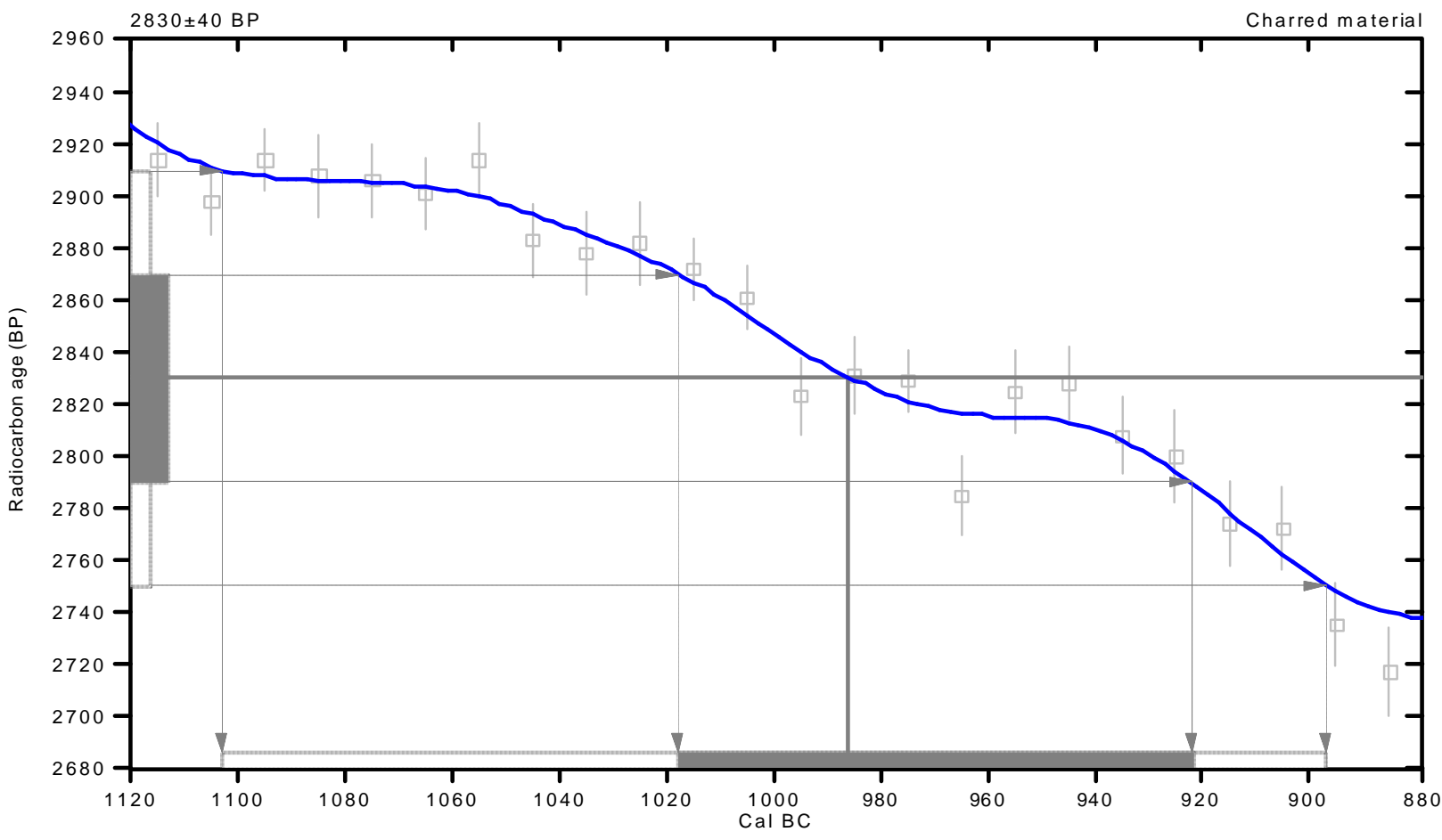

References:

Database used

Calibration Database

Editorial Com ment

Stuiver, M., van der Plicht, H., 1998, Radioca rbon 40(3), pxii-xiii

INTCAL98 Radiocarbon Age Calibration

Stuiver, M., et. al., 1998, Radiocarbon 40(3), p1041-1083

Mathe matics

A Simplified Approach to Calibrating C14 Dates

Talma, A. S., Vogel, J. C., 1993, Radiocarbon 3 5(2), p317-322

\section{Beta Analytic Inc.}

4985 SW 74 Court, Miami, Florida 33155 USA $・$ Tel: (305) $6675167 \cdot$ Fax: (305) $6630964 \cdot$ E-Mail: beta@ radiocarbon.com 

Appendix B

\section{Vertebrate Faunal Remains}




\section{Appendix B: $\quad$ Vertebrate Faunal Remains}

\begin{abstract}
A total of 290 vertebrate faunal remains, weighing $524.32 \mathrm{~g}$, was recovered from 11 sites during this project. A few general observations are listed here. Information on identified taxa are discussed with each site description in Chapter 6 of volume 1. A complete list of data collected on the bone in this collection is provided as Table B-1 in this appendix.
\end{abstract}

Barbara A. Meissner

The bone was recovered by screening through $0.64 \mathrm{~cm}$ ( $1 / 4$-inch) screens. All bone was washed in tap water and airdried. The bone was identified to the most specific taxon possible using the comparative collection at CAR, as well as several reference texts (Balkwill and Cumbaa 1992; Cohen and Serjeantson 1996; Gilbert 1990; Hildebrand 1955). Identifications were conservative, i.e., bone was identified as bison (Bison bison) only when it could be differentiated from cattle (Bos taurus) and horse (Equus caballos). All bone was weighed. Evidence of exposure to heat was noted on all bone. Element, portion of element, evidence of immaturity, butcher marks, and pathologies were noted on bone identified to the order taxonomic level. Bone that had been intact in situ, but was subsequently broken, was counted as a single specimen, and a note to this effect added in Table B-1. When bone could be identified only to class (e.g., mammal, bird, etc.), an estimate of the size of the animal was made when possible. After the analysis, the bone was bagged by unit and level. Bone identified to at least the order taxonomic level was bagged separately and included in the unit-level bags with unidentified bone.

In general, the bone from the Camp Bowie sites was in moderate to poor condition. Virtually all the bone showed at least some sign of chemical weathering. This form of weathering is a function of biological action (bacteria and/ or fungi) on the bone, and is particularly likely to be a problem in basic soils (Lyman 1994; White and Hannus 1983). Acids secreted by micro-organisms as they digest the collagen fraction of the bone also dissolve the hydroxyapatite fraction (White and Hannus 1983). The result is a pitted or "chewed" appearance to the surface and a general softening of the bone, making it more friable.

Only four taxa were identified to the genus level. There were bison (Bison bison), white-tailed deer (Odocoileus virginianus), blacktailed jackrabbit (Lepus californicus) and cottontail rabbit (Sylvilagus sp.). All of these genera would have been used as food by prehistoric peoples.

A few of the bones $(n=20 ; 6.9$ percent) showed some evidence of heat alteration. Only one bone was completely calcined. The low percentage of burned bone and the relatively few bones calcined or partially calcined (6 of 20 ; see Table B-1) suggests that the burning was accidental, and that bones were not routinely tossed in the fire as a disposal method.

No butcher marks were noted on any of the bone. This is partially due to the small size of the collection, but the extensive chemical weathering would tend to hide impact scars and relatively superficial cut and chop marks.

Only one bone, the calcaneus of a bovid, appears to have been rodent chewed, but again, rodent and even carnivore chewing would not tend to be visible on chemically weathered bone.

Unfortunately, the small number of bones in this collection are in too poor a condition to be useful in understanding the meat diet of the prehistoric peoples of Camp Bowie. The poor condition of the bone also makes it impossible to determine if the small number of bones is due to poor preservation or if there were, in fact, few bones left at these sites. 


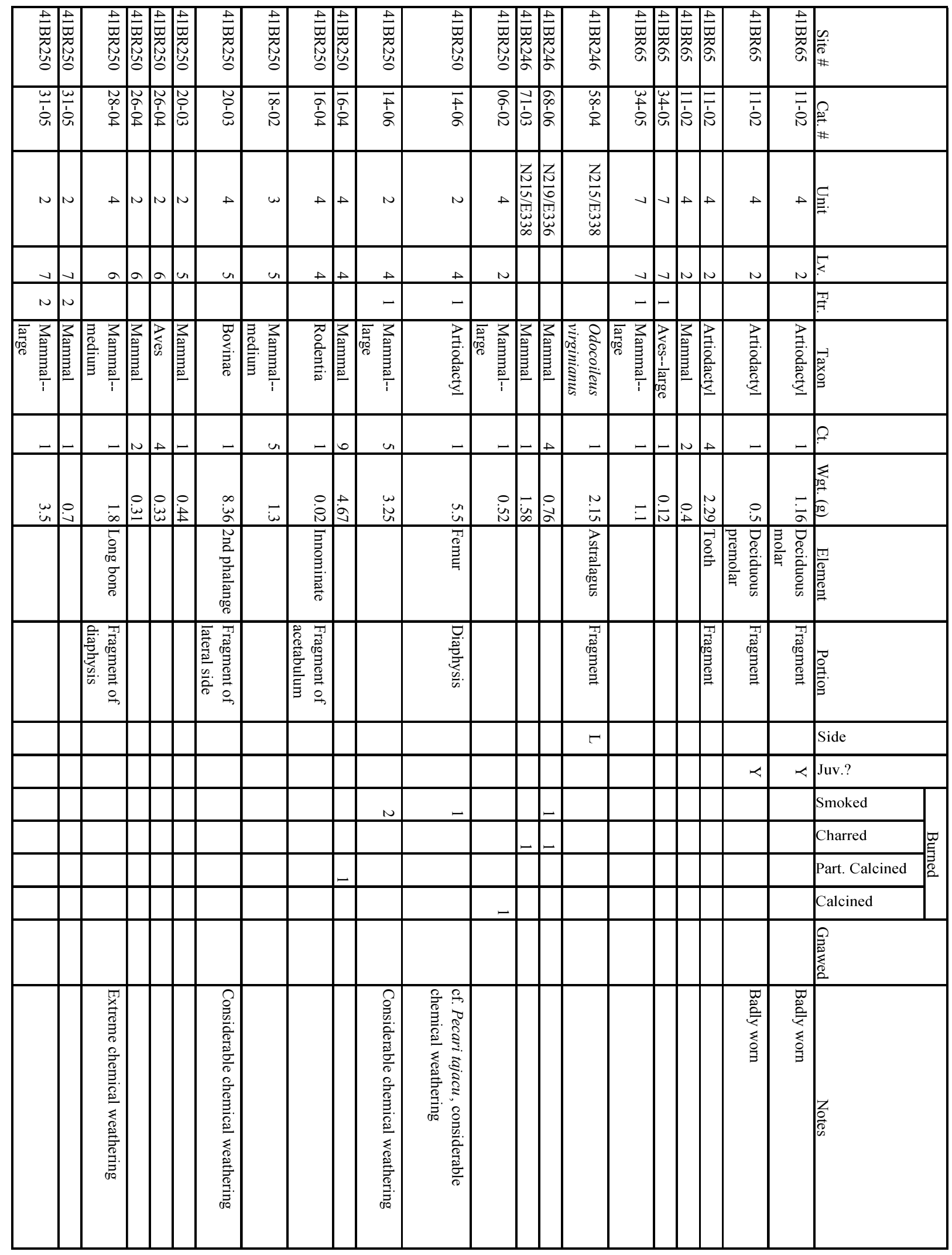




\begin{tabular}{|c|c|c|c|c|c|c|c|c|c|c|c|c|c|c|c|c|c|}
\hline 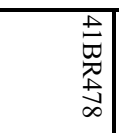 & 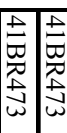 & 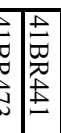 & 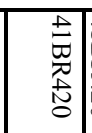 & 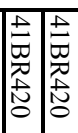 & 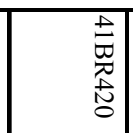 & 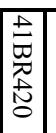 & 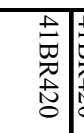 & 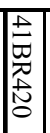 & 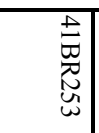 & $\begin{array}{l}t \\
\underset{\tilde{J}}{\tilde{U}} \\
\underset{\omega}{J}\end{array}$ & 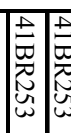 & & 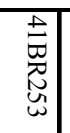 & 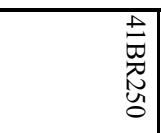 & 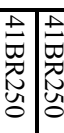 & 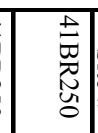 & 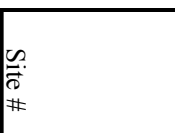 \\
\hline$\frac{N}{\dot{O}}$ & 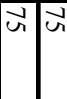 & 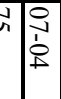 & $\begin{array}{l} \\
\text { ì } \\
\text { in }\end{array}$ & & $\begin{array}{l} \\
\\
i \\
i\end{array}$ & 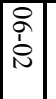 & \begin{tabular}{l|l}
0 \\
$\vdots$ \\
$\vdots$
\end{tabular} & \begin{tabular}{|l|} 
\\
$\vdots$ \\
0 \\
0
\end{tabular} & $\begin{array}{l}\mathbf{w} \\
\underline{u} \\
\grave{b}\end{array}$ & $\stackrel{\underline{w}}{\underline{s}}$ & 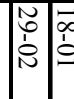 & $\begin{array}{l}0 \\
\vdots \\
0\end{array}$ & $\begin{array}{l}9 \\
0 \\
0 \\
0\end{array}$ & $\begin{array}{l}w \\
\text { D. } \\
\vdots \\
\vdots\end{array}$ & 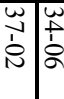 & $\begin{array}{l}w \\
\\
\vdots \\
u \\
u\end{array}$ & 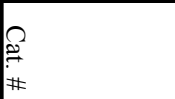 \\
\hline 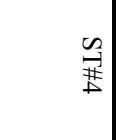 & 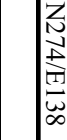 & 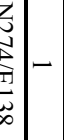 & & & & & - & - & & $u$ & o u & $u$ & $\omega$ & $N$ & $+N$ & $\sim$ & E. \\
\hline \pm & $\pm \quad$ & $\begin{array}{l} \\
\end{array}$ & $\omega$ & $\omega$ & $\omega$ & $\omega$ & $\omega$ & $N$ & $\checkmark$ & 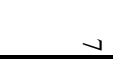 & + & $u_{1}$ & $\omega$ & 하 & $\infty \infty_{\infty}$ & 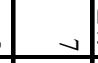 & $\xi$ \\
\hline & & & $N$ & $N \mid N$ & $N$ & N & N & - & N & n & & $\omega$ & - & . & n & $N$ & 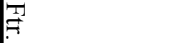 \\
\hline 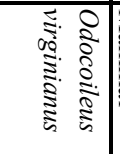 & 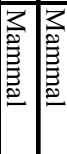 & & 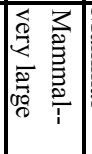 & 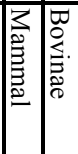 & 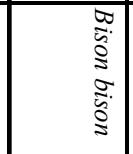 & 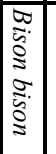 & 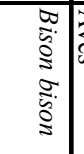 & 赵 & 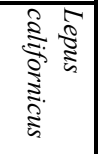 & 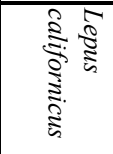 & 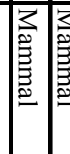 & & 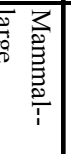 & 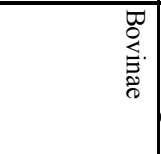 & 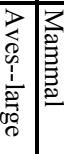 & 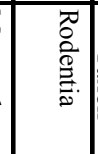 & 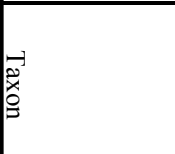 \\
\hline$N$ & \begin{tabular}{|l|l} 
& un \\
\end{tabular} & - & \pm & \begin{tabular}{|l|l|l}
$\vec{v}$ & $\vec{\omega}$ \\
\end{tabular} & - & - & - & - & - & _ & -1 & $N$ & N & - & $a_{N}$ & - & $\digamma$ \\
\hline $\begin{array}{c}\tilde{U} \\
\tilde{N} \\
\pm \\
\end{array}$ & $\begin{array}{ll}\vec{\Delta} \\
\dot{N} \\
\end{array}$ & $\begin{array}{l}-\dot{0} \\
0 \\
\end{array}$ & $\begin{array}{l}u \\
u \\
\infty \\
u \\
\end{array}$ & 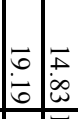 & \begin{tabular}{l}
$\stackrel{\tilde{N}}{0}$ \\
\cline { 1 - 1 } \\
\end{tabular} & \begin{tabular}{|l|} 
\\
+ \\
+ \\
\end{tabular} & $\begin{array}{c} \pm \\
\stackrel{ \pm}{*}\end{array}$ & $\frac{1}{+}$ & : & $\stackrel{8}{8}$ & $\stackrel{0}{i}$ & $\stackrel{0}{\omega}$ & $\begin{array}{r}\vec{\infty} \\
0\end{array}$ & $\begin{array}{r}w \\
w \\
\infty \\
0 \\
u \\
\end{array}$ & $\begin{array}{l}n \\
\\
\dot{i}\end{array}$ & 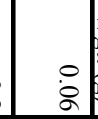 & 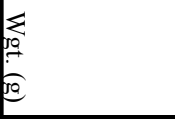 \\
\hline 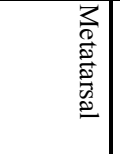 & & & & 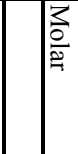 & $\vec{Z}$ & 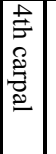 & 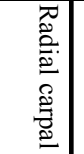 & & 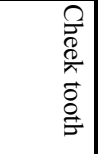 & $\begin{array}{l}\frac{3}{3} \\
\frac{0}{0} \\
\frac{5}{0}\end{array}$ & & & & 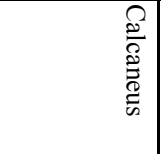 & & 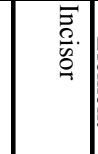 & 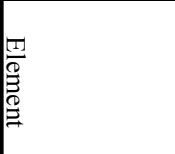 \\
\hline 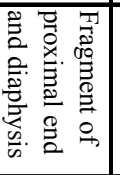 & & & & 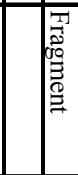 & 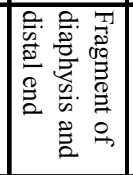 & 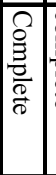 & 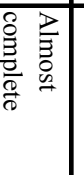 & & 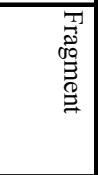 & 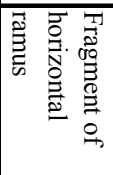 & & & & 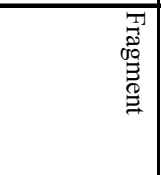 & & 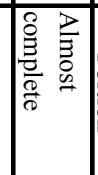 & \\
\hline & & & & & $r$ & $\pi$ & $\approx$ & & & $\pi$ & & & & & & & Side \\
\hline & & & & & & & & & & & & & & & & & Juv.? \\
\hline & & & & & & & & & & & & & 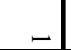 & & & & Smoked \\
\hline & & 4 & & & & & & & & & & & & & & & Charred \\
\hline & $\omega$ & ـ & & & & & & & & & & & & & & & Part. Calcined \\
\hline & & & & & & & & & & & & & & & & & Calcined \\
\hline & & & & & & & & & & & & & & $\begin{array}{l}\pi \\
0 \\
0 \\
0\end{array}$ & & & 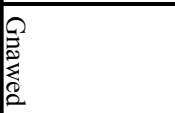 \\
\hline 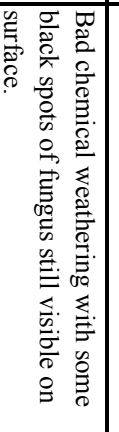 & & & & & 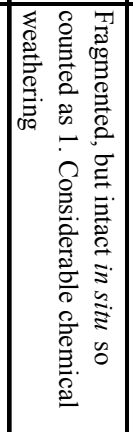 & 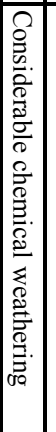 & 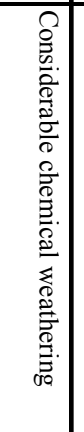 & & & & & & & 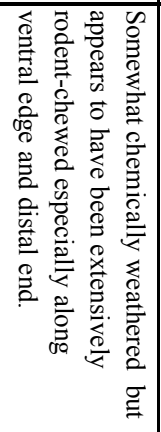 & & & 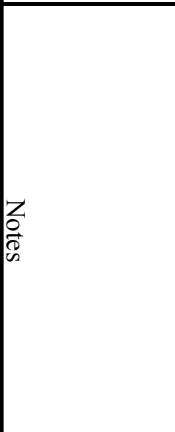 \\
\hline
\end{tabular}

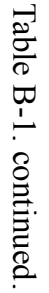




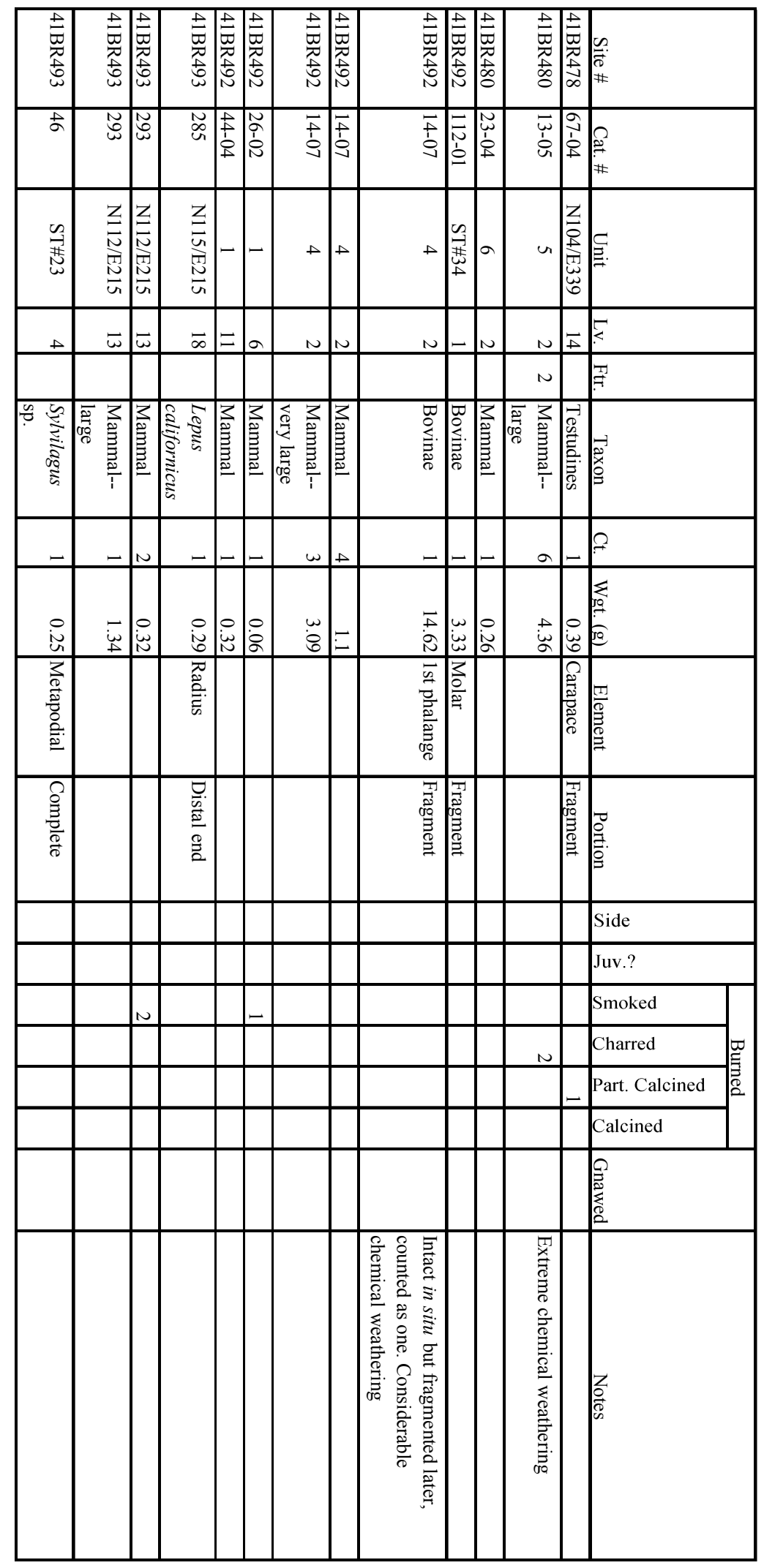

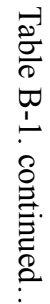




\section{References Cited}

Balkwill, D. M., and S. L. Cumbaa

1992 A Guide to the Identification of Postcranial Bones of Bos taurus and Bison bison. Canadian Museum of Nature, Ottawa.

Cohen, A., and D. Serjeantson

1996 A Manual for the Identification of Bird Bones from Archaeological Sites. Revised edition. Archetype Publications, London.

Gilbert, B. M.

1990 Mammalian Osteology. Missouri Archaeological Society, Columbia.

Hildebrand, M.

1955 Skeletal Differences Between Deer, Sheep, and Goats. California Fish and Game 41:327-346.

Lyman, R. L.

1994 Vertebrate Taphonomy. Cambridge University Press, Cambridge.

White, E. M., and L. A. Hannus

1983 Chemical Weathering of Bone in Archaeological Soils. American Antiquity 48:316-322. 


\section{Appendix C}

\section{Ethnobotanical Remains}




\title{
Appendix C: Botanical Perspectives on Land Use in the Cross Timbers and Prairies
}

\section{Plant Remains from Burned Rock Middens in Brown County, Texas}

\author{
J. Philip Dering
}

Burned rock middens, the remains of earth ovens, are indicators of plant food processing (Black et al. 1997). The most likely plants to be processed in these types of facilities are either xeric-adapted species such as agave or sotol, or geophytes. Geophytes store their food energy below the ground in organs such as bulbs, corms, tubers, or rhizomes. Bulbs are the most common type of geophyte recovered from sites in Texas. Identification of bulbs from archaeological sites can provide very useful information on both prehistoric land use and vegetation ecology. This is because collecting and processing plant foods in large quantities occurs only under certain conditions. First, the plants have to be growing in sufficiently dense stands to warrant bulk processing. Experiments have shown that a $1.5 \mathrm{~m}$ oven can hold over 2,000 bulbs the size of wild onions (Dering 2001). Second, the labor investment is relatively high, and therefore there has to be a need for this food source. This means that more easily processed food sources are not available in sufficient quantity to support the group (cf. Thoms 1989).

After excavating a complex of burned rock middens on 16 sites in Brown County, Texas, the Center for Archaeological Research submitted for identification carbonized plant specimens from 83 different lots along with 35 flotation samples for analysis. It was not known at the time, although it was suspected, that almost all of the charred plant specimens from these sites were bulbs or fragments of bulbs. As such, this represents the largest preserved assemblage of plant food from earth ovens recovered from sites located on the periphery of the southern plains. This report presents a description of the plant materials from these sites. The archaeobotanical assemblage from the Brown County sites will be interpreted and compared to other sites across central Texas.

\section{Methods}

\section{Preliminary Sorting}

The analysis began by following standard archaeobotanical laboratory procedures. Specimens were sorted into general categories such as wood, seed, or bulb/corm/tuber using an epi-illuminated light microscope at $8-35$ power.
Identification of carbonized wood was accomplished by using the snap technique, examining the specimens at 8 to 45 magnifications with a hand lens or a binocular dissecting microscope, and comparing them to references in the archaeobotanical herbarium. Seeds, when present, were compared to the reference collection housed in the archaeobotanical laboratory.

Remains of carbonized geophytes (bulbs/corms/tubers) were the most abundant of the plant materials recovered from the site. Because this is an unprecedented situation, I separated the geophytic materials and adopted a series of analytical procedures that were tailored to the identification of vegetative plant remains.

\section{Identification of Geophytes}

Geophytes are plant species which reserve energy in specialized underground storage organs. The primary function of the underground tissues is to store food reserves, nutrients, and moisture for seasonal growth and development and, thus, ensure the survival of the species. The geophyte genera include both monocotyledonous and dicotyledonous species, and they can be separated into two groups, bulbous and tuberous (De Hertogh and Le Nard 1993:7). Geophytes are diverse, both morphologically and physiologically, and an understanding of their morphology is essential for identification.

Geophytes are not easy to identify. There is no taxonomic description or identification key that aids in the identification of bulbs. Plants are primarily classified and identified by the structure of their flowers and fruits, and to a lesser degree by molecular signatures. When confronted by vegetative (i.e., non-flowering) plant remains, the analyst must devise another means of identifying the specimens in question. Some keys for the identification of non-floral parts have been devised and are commonly available. For example, foresters and wood technologists have assembled reference books on wood identification (Panshin and de Zeuw 1979). Several seed manuals are available for the identification of weed seeds or crop seeds (Martin and Barkley 1982). 
Although bulbs grow underground, they are not roots but instead are modified leaves arranged in a rosette fashion around a compressed, central stem, similar to an artichoke. The thickened, modified leaves of a bulb are termed bulb scales. Because they are leaves, the epidermal cells (outer skin) of bulb scales have distinctive shapes that are duplicated within a species, and are often unique to that species. The epidermal pattern provides a key diagnostic feature for identifying the genus or species of the plant because the overall shape of any bulb is so modified during the cooking and charring process.

A key factor in classifying geophytes as bulbs, corms, or tubers, etc., is to determine the precise origin and nature of the tissue that serves as the primary storage organ. Generally speaking, bulbous plants have storage tissues that originate from modified leaves, and tuberous plants have storage tissues that originate from modified stems. Many geophytes can be classified based on the accepted definitions for bulbous and tuberous plants.

\section{Bulb}

A bulb is an underground vegetative plant organ that stores relatively large amounts of energy, allowing a plant to overwinter or aestivate during times when environmental conditions are not conducive to growth. Bulbs serve as a storehouse of energy for initial growth during the early stages of a growing season. Because they store large quantities of food energy, bulbs serve as an excellent carbohydrate source for any predator in search of food, and that includes humans. Therefore, it should be no surprise that bulbs are recovered from many archaeological sites in the region.

A bulb has a shortened stem called the basal plate that has one or more apical meristems and is enclosed by several fleshy scales, usually in a rosette pattern. The basal plate also contains adventitious root initials. The scales are the primary storage tissue in true bulbs. Depending on the species, scales are modified leaves or leaf bases. They are enlarged with fleshy tissue that stores food and water. Bulbs can be either tunicated, or non-tunicated. Some bulbs are replaced annually, while others are perennial. There is great diversity among the true bulb species. Several bulbforming plants are likely to be recovered from archaeological sites, including several species of onion (Allium spp.), false garlic (Nothoscordum bivalve (L.) Britt.), Eastern camas (Camassia scilloides (Raf.) Cory), dog's-tooth violet (Erythronium mesochoreum Knerr.), and prairie celestial (Nemastylis geminiflora Nutt.).

\section{Corm}

A corm has an enlarged stem (basal plate) that has distinct nodes and internodes. The basal plate is enclosed by several dry, scale-like leaves (tunics) and contains adventitious root primordia. In contrast to a true bulb, the primary storage organ of the corm is the basal plate instead of modified leaves or leaf bases. Spring beauty (Claytonia virginica L.) or gayfeather (Liatris punctata Hook) are the most likely cormforming plants that would be recovered from archaeological sites in Texas.

\section{Tuberous Plants}

Tuberous plants comprise a group that stores food in tubers, tuberous roots, rhizomes, or enlarged hypocotyls. In outward appearance, tubers can appear very similar to charred bulbs. The distinction between tuberous and bulbous plants lies in the tissue of origin and in the manner in which tissues are organized internally in the plant structure. The storage areas in bulbous plants originate from either the basal plate or from leaves/leaf bases. The storage areas in tubers originate from stem or root tissue.

\section{Tuber}

A tuber is a modified stem. The enlarged stem tissue is able to store both food and water. Tubers have one or more apical buds from which the above-ground stems sprout. Roots originate from root primordia located on the base of the tuber. Tuber-generating plants most likely utilized by the foragers of the Southern Plains include scurfpea/ snakeroot (Pediomelum spp.), arrowhead/duck-potato (Saggitaria latifolia Willd.), and ground nut (Apios americana Medic).

\section{Rhizome}

A rhizome is a specialized, horizontal stem that often grows underground. Rhizomes of many plants are enlarged and function as storage organs. Rhizomes of twist-leaf yucca (Yucca rupicola) are very large underground storage organs that can grow to six feet in length and weigh several pounds. Commonly utilized rhizomes include cattail (Typha spp.) and yellow lotus (Nelumbo lutea Willd.).

To further complicate matters, the gross morphology of the geophytic storage organs can be similar among different species. Figure C-1 demonstrates these similarities using reference material. I have chosen plants that have globose storage organs of various origin, including bulbs, a corm, 


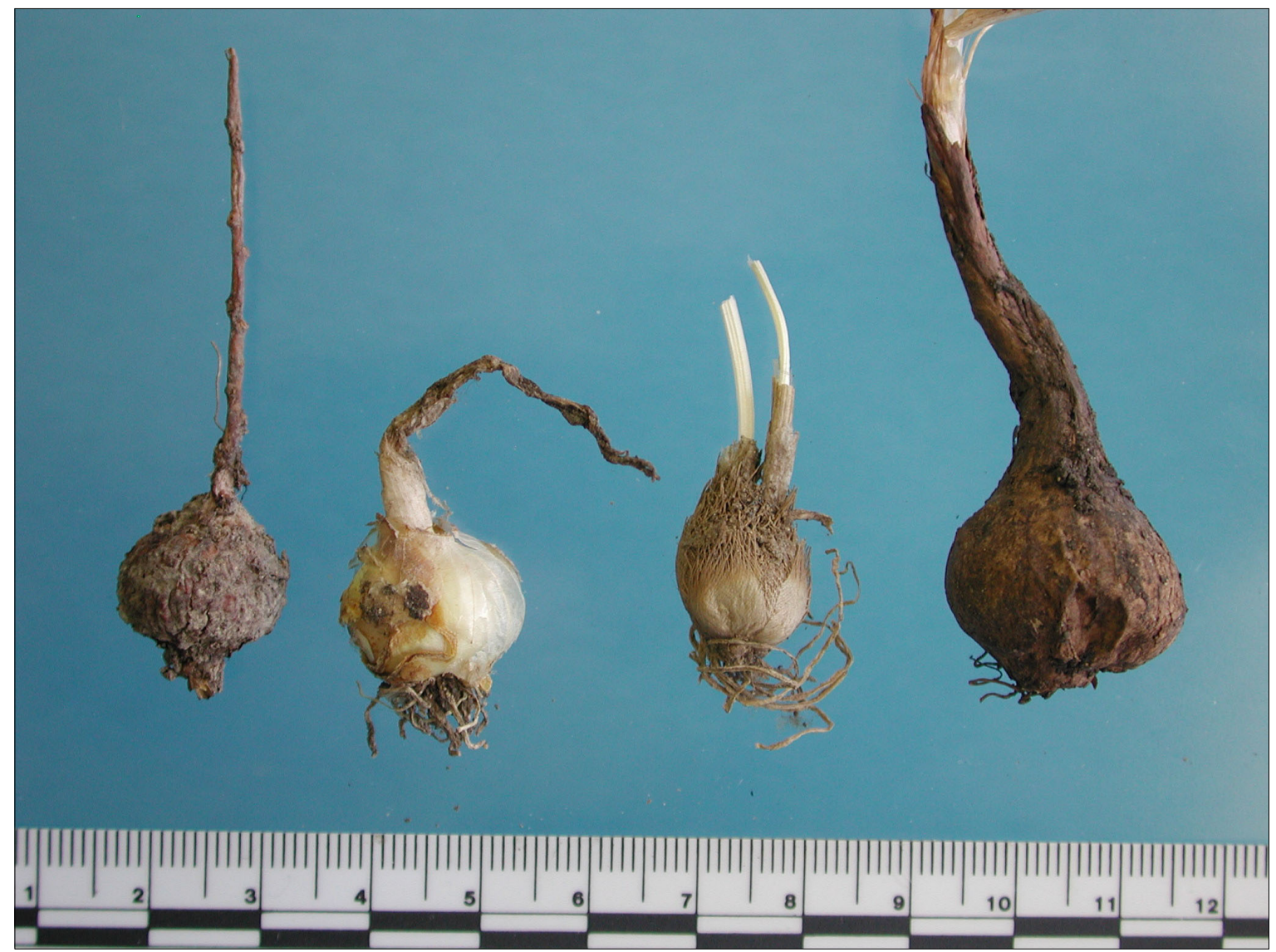

Figure C-1. Geophytes with globose bulbs or tubers that grow in the study area. Left to right, Pediomelum (tuber), Nothoscordum (bulb), Allium (bulb), Camassia (bulb).

and a tuber. When this material is charred it requires careful examination to distinguish the various species. While identifying fresh geophytic material can be a challenge; identifying charred material is daunting. Keep in mind that material under both heat and pressure can change shape, as illustrated by the Horn Shelter bulb material in Figure C-2.

\section{Establishing a Reference Collection}

The relatively recent discovery of geophyte fragments from several sites has made it necessary to assemble a reference collection of what are commonly referred to as root foods. Because there is no available key to the underground parts of plants, a special reference collection needed to be established. Identification of these materials is a step-wise process that proceeds from the description of gross anatomy to microscopic examination of epidermal features.

Emphasis has been placed on regional collections specific to the study area that includes plants that appear in ethnobotanical or ethnohistorical references. For the Camp Bowie project, particularly close attention was paid to the bulbs of onion (Allium spp.), false garlic (Nothoscordum bivalve), Eastern camas (Camassia scilloides), dog's-tooth violet (Erythronium mesochoreum Knerr.), and prairie celestial (Nemastylis geminiflora Nutt.). The epidermal features are described and photographed from fresh material. Figures C-3, C-4, C-5, and C-6 illustrate the epidermal shapes noted in the current study. It is clear from these figures that the analyst should examine inner and outer epidermis. 


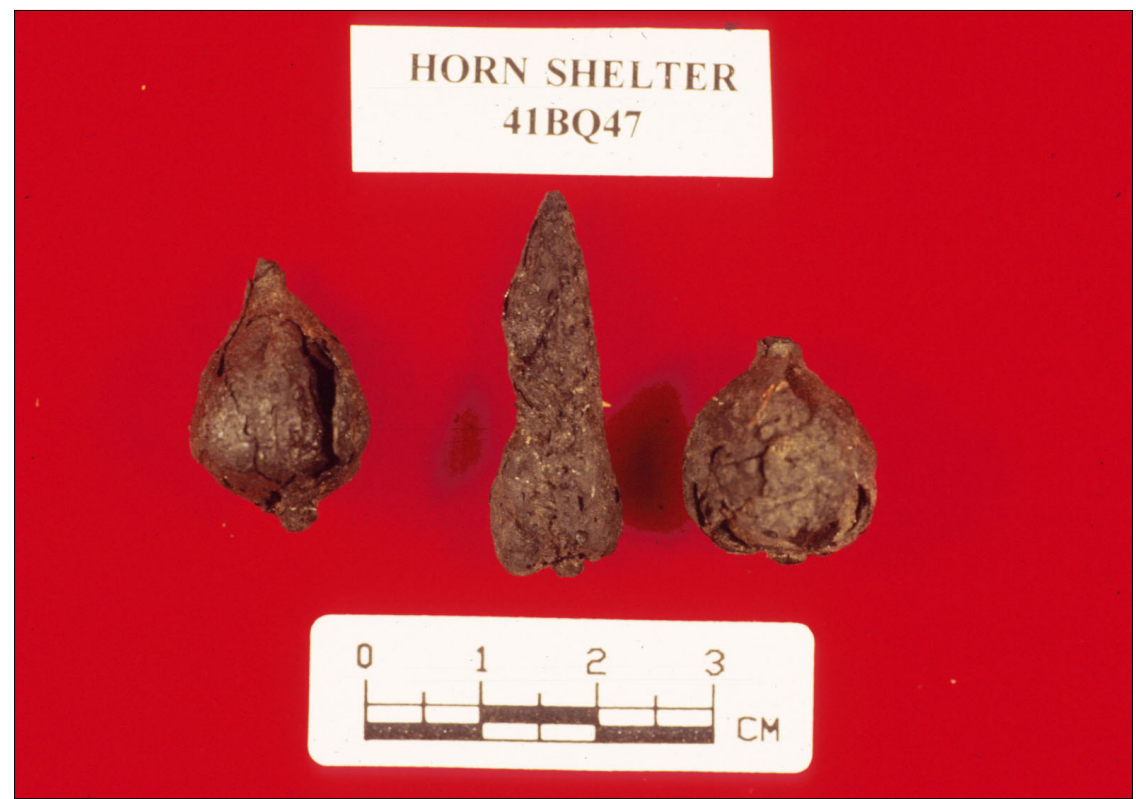

Figure C-2. Carbonized geophytic remains from Horn Shelter. Note differences in gross morphology.

\section{Examining Archaeological Material}

Due to the variables encountered in identifying geophytes, adequate identification of geophytic material recovered from archaeological sites requires a systematic examination of the specimen beginning with the description of the gross morphology and ending with microscopic examination of certain characters. For the Camp Bowie materials, the following steps were taken:

1) Each specimen was examined under a low-power epiilluminated dissecting microscope. Gross anatomical features were noted, including whether bulb scales and a central stem were present.

2) If no bulb scales were present, the sample was snapped or cut in the transverse axis to determine if the tissue is organized like a stem (xylem - a corm) or a root (cortex - a tuber).

3) If the material was a true bulb, the bulb scales were examined for the presence of epidermis. If epidermal features were discovered some of the material was attached to an aluminum stub for examination using a scanning electron microscope.
4) Bulb fragments were examined with a scanning electron microscope (SEM) to observe epidermal patterns on the both the inner and outer surfaces of the bulb scale. Bulb scale fragments were attached to aluminum stubs using $12 \mathrm{~mm}$ diameter carbon conductive adhesive tabs. After drying the samples for 24 hours in a desiccator, the samples were pretreated by evacuating a vacuum chamber to 60 millitor and coating the target with gold-palladium for eight minutes. A thick coating produced the best results. The samples were photographed using Polapan 400 film at low magnification (100-350 X). Identification was established by comparison to a reference collection of bulb scale photographs established at Texas A\&M University.

Each bulb scale consists of at least three tissue types arranged in layers - the inner epidermis, the outer epidermis, and the palisade parenchyma which is sandwiched in between the two epidermal layers. The middle parenchyma layer usually contains abundant starch grains that must be distinguished from the epidermal material. I attempted to secure images of both the inner and outer epidermis for comparison to reference materials because it is the cell patterns that appear to be most useful in identifying the bulb. 


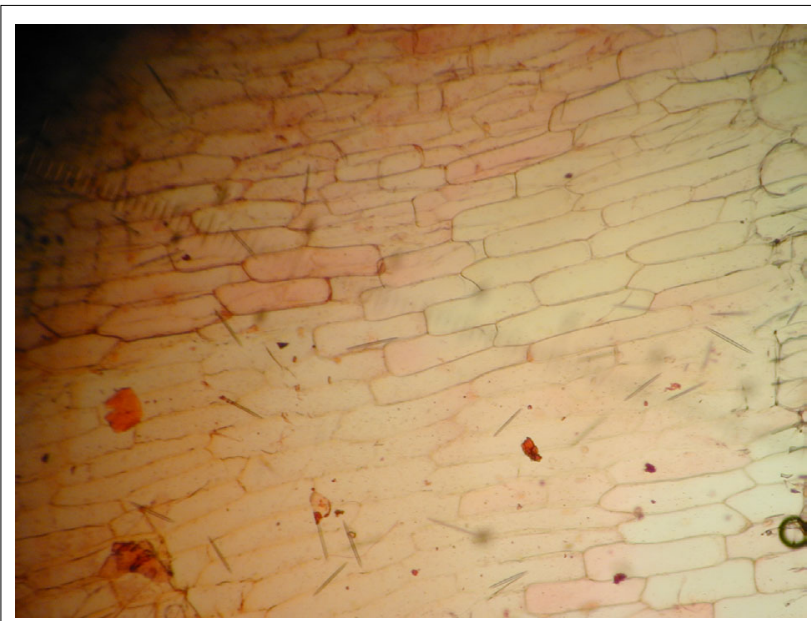

Eastern camas

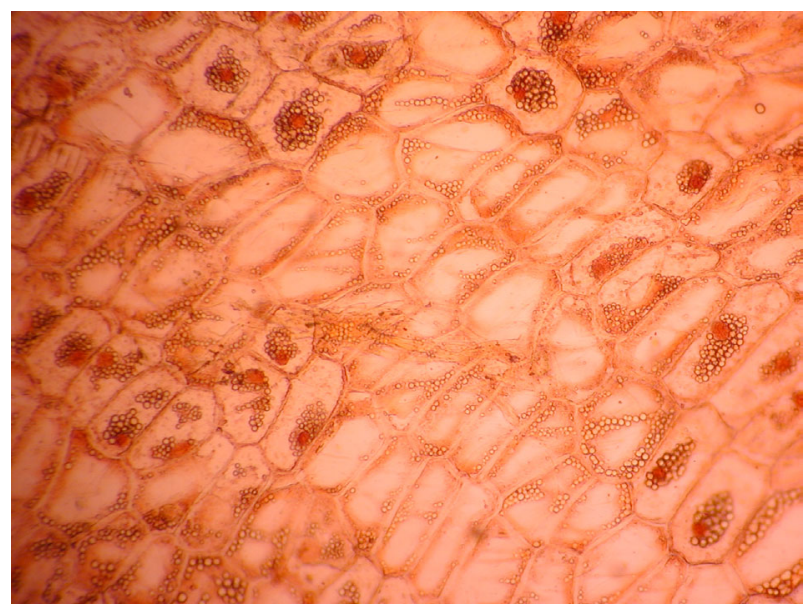

dog's-tooth violet

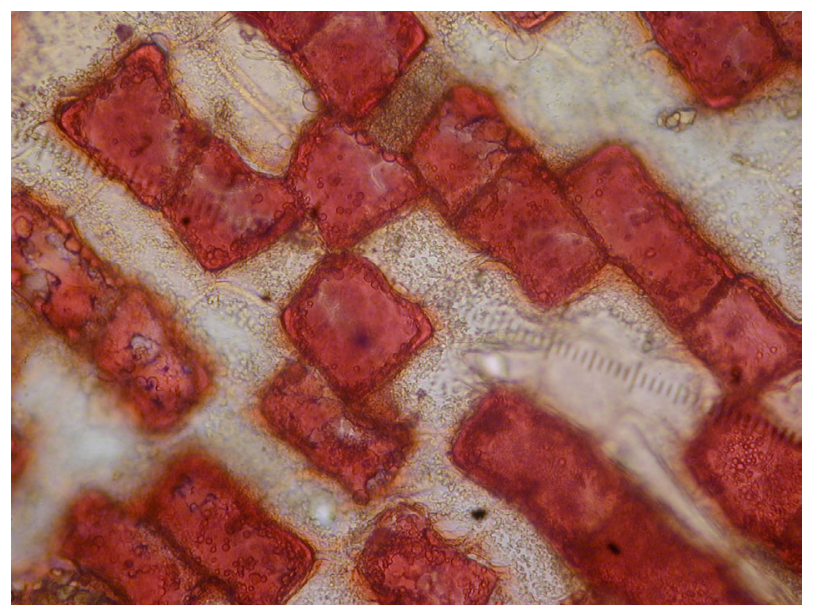

prairie celestial

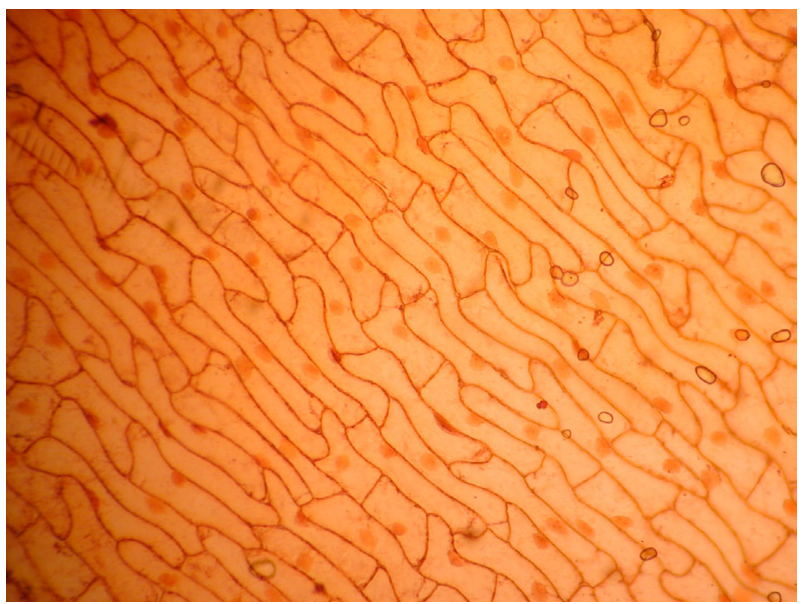

false garlic

Figure C-3. Inner surface bulb scale epidermis from four common geophytes (100X).

\section{Results}

The charring process often makes it difficult to distinguish between the cells in the parenchyma and the cells in the epidermis at low magnification, which complicates selection of the material that is attached to the aluminum stubs. Because of the high resolution of the scanning electron microscope images, it is very easy to distinguish the epidermal tissue. In order to accomplish this determination, however, it was usually necessary to conduct several scans of each bulb fragment before I had secured good images of the epidermal surface of a bulb fragment. A total of 60 stubs was analyzed representing 11.5 hours of beam time on the SEM.
Examination of the gross morphology and anatomy of the archaeological specimens using light and scanning electron microscopy produced identification of five potentially important plant resources, including three bulb taxa, one tuber type, and one fruit from a woody plant. The three bulbs are Eastern camas (Camassia scilloides), dog's-tooth violet (Erythronium mesochoreum Knerr.), and wild onion (Allium spp.). Globose tubers were detected in the samples from 41BR246, but I was unable to confirm the identification. They are similar in gross anatomy to reference material identified as Pediomelum hypogaea T. \& G., but I have not been able to develop a sufficiently inclusive 


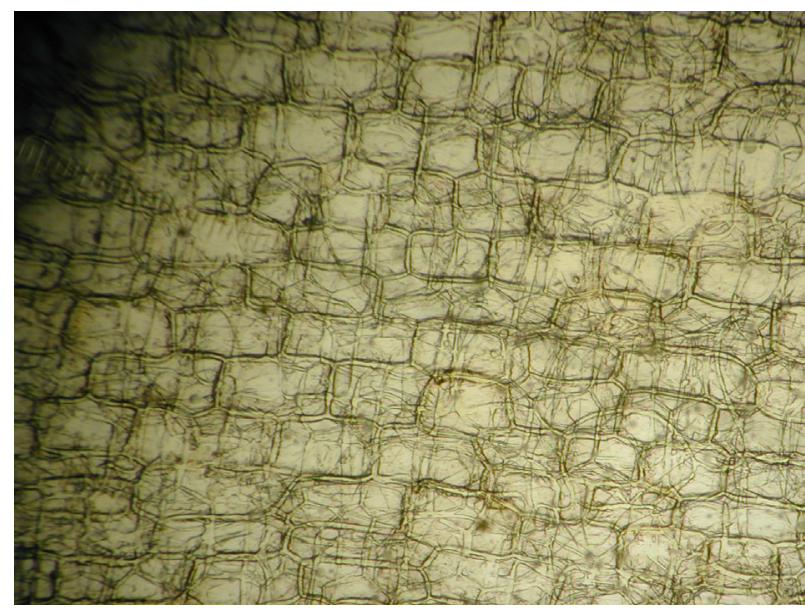

Eastern camas

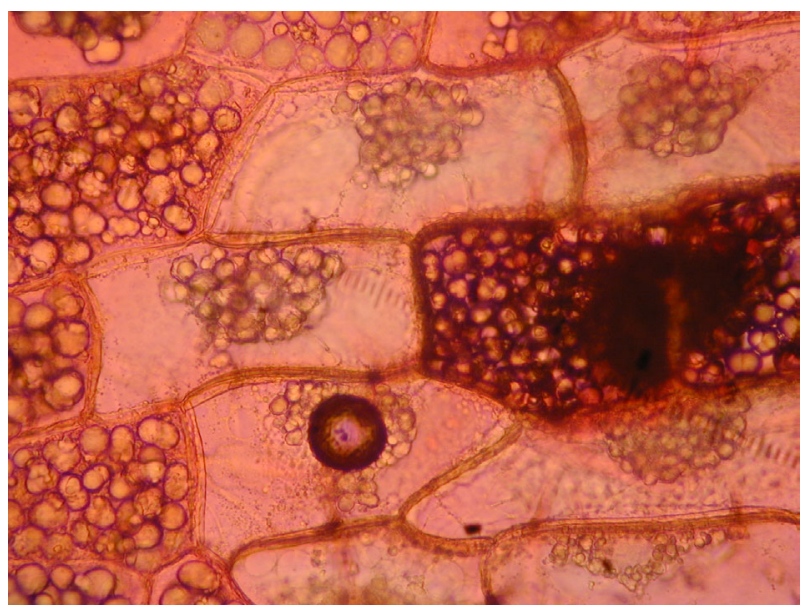

dog's-tooth violet

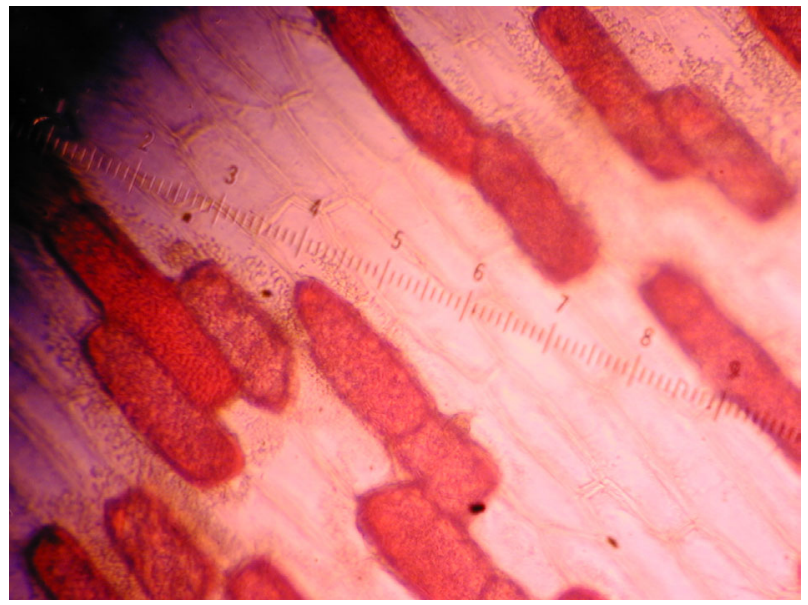

prairie celestial

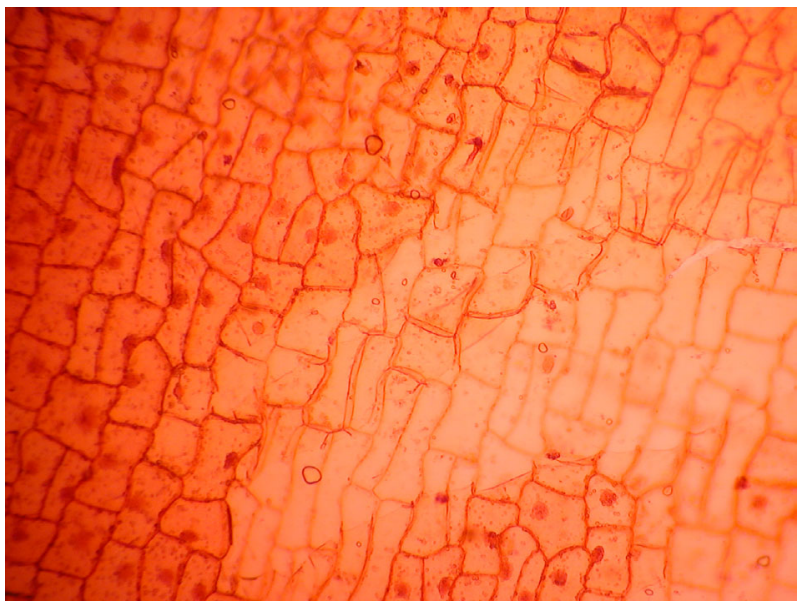

false garlic

Figure C-4. Outer surface bulb scale epidermis from four common geophytes (100X).

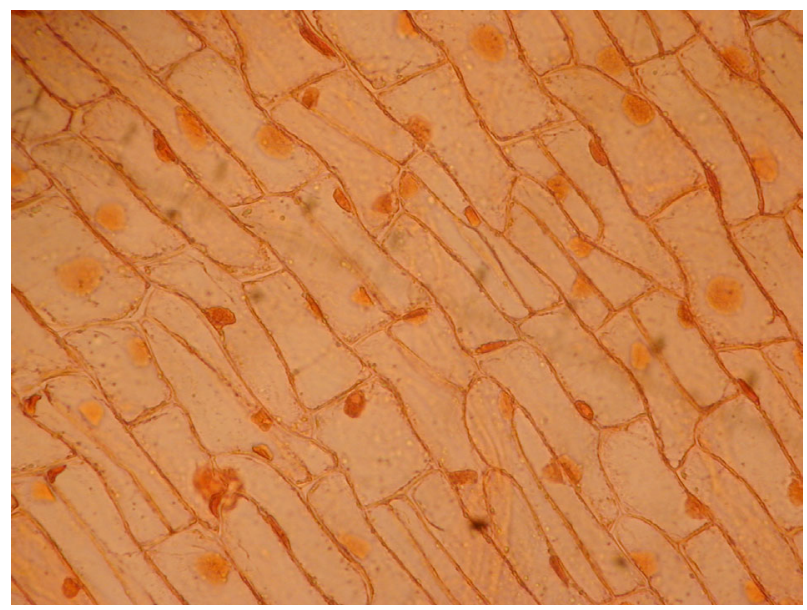

inner epidermis

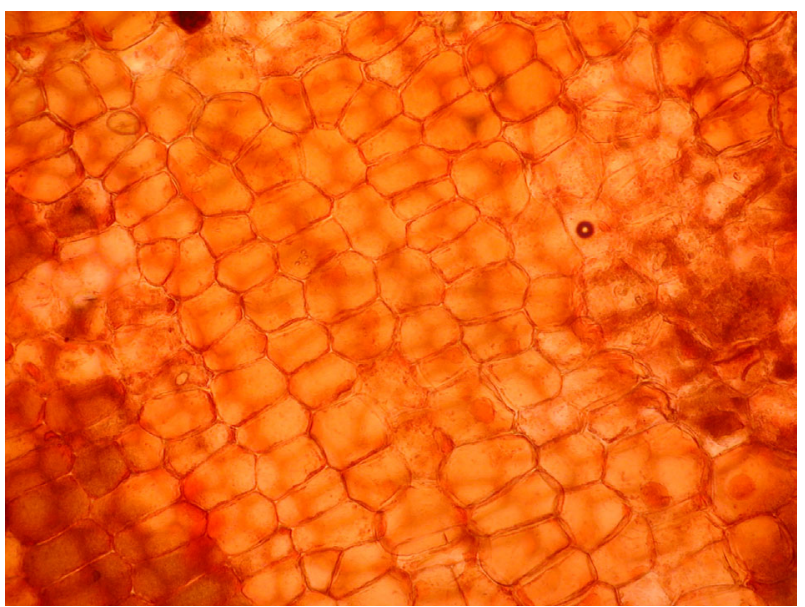

outer epidermis

Figure C-5. Bulb scale epidermal patterns of Drummond onion (Allium; 100X). 


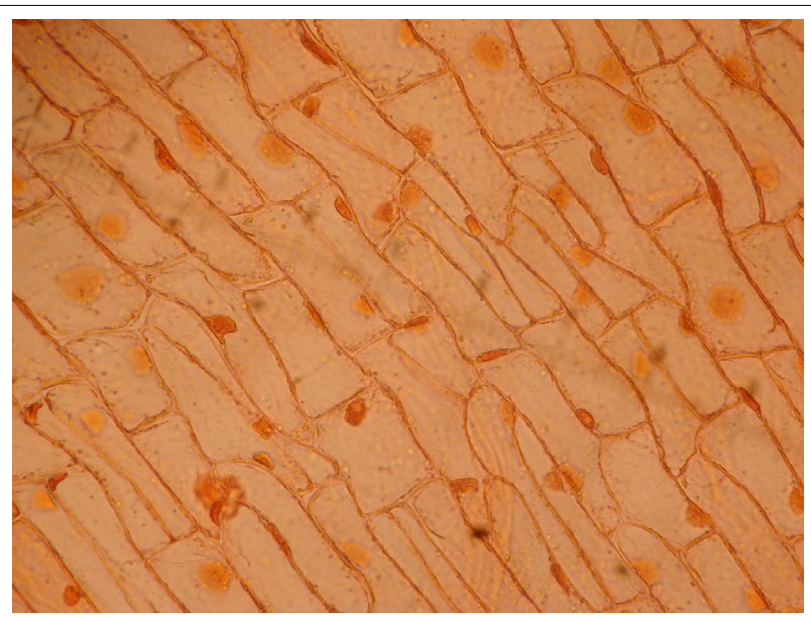

Drummond onion inner epidermis

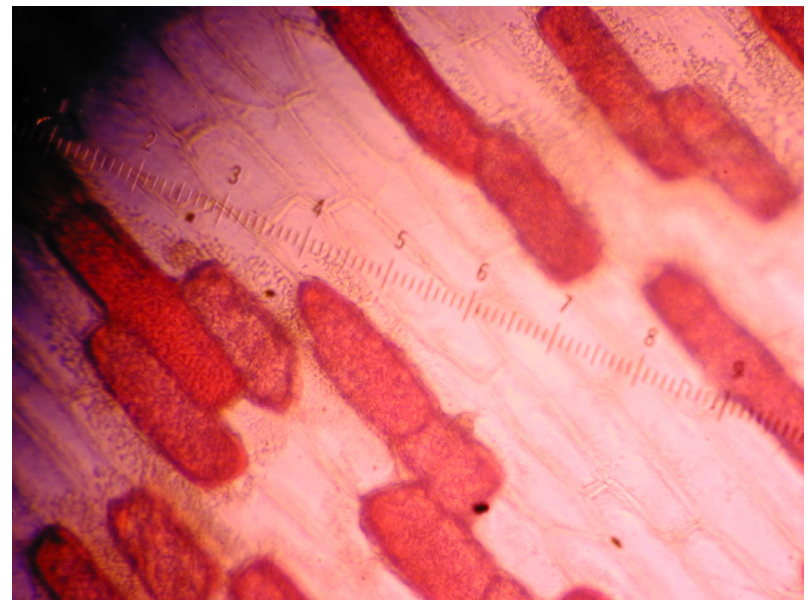

prairie celestial outer epidermis

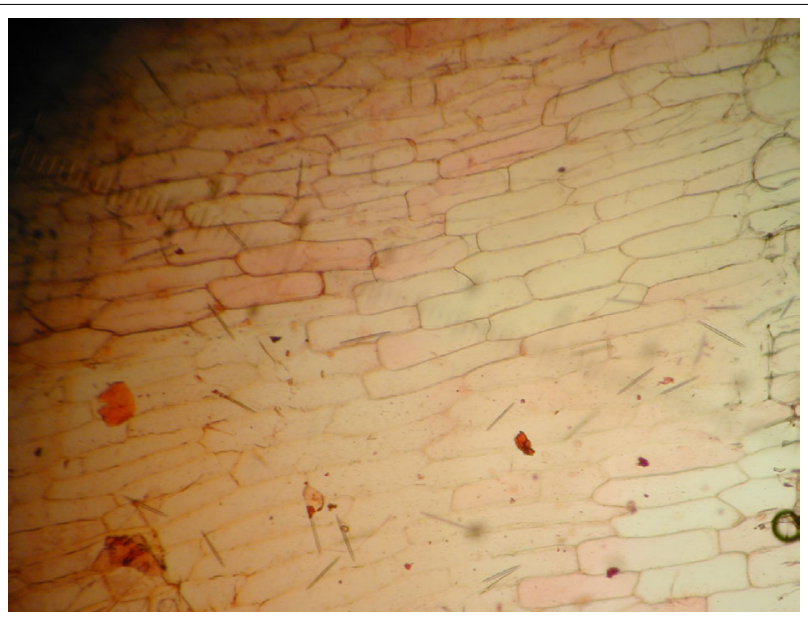

camas inner epidermis

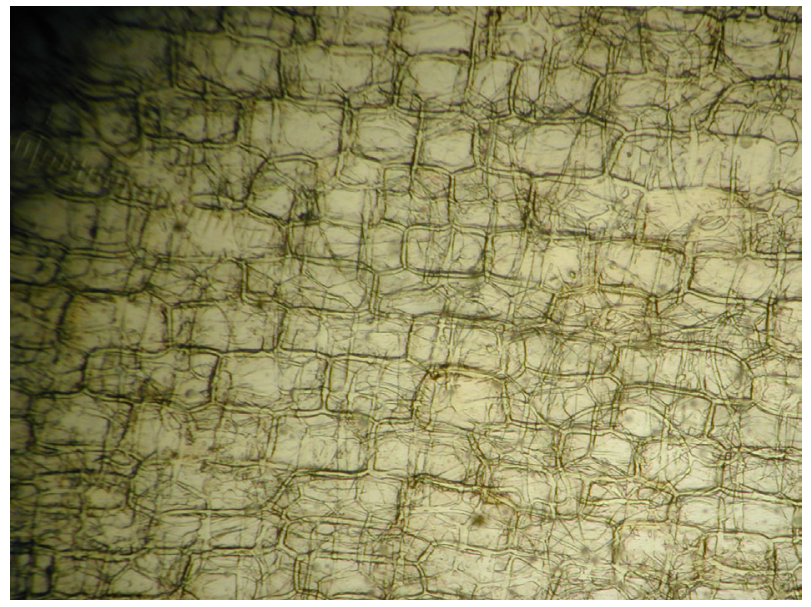

camas outer epidermis

Figure C-6. Similar epidermal patterns: Drummond onion, camas, and prairie celestial (100X).

reference collection of tuber-bearing plants to absolutely determine an identification. In addition to the geophyte plant resources, mesquite seed and fruit fragments were identified from 41BR478.

\section{Macrobotanical Specimens}

Table C-1 presents the results of the macrobotanical analysis by sample and site number. Samples examined using the light microscope were separated into general categories, and the small amount of wood that was noted in the samples was identified by gross anatomical characteristics examined at low magnification. Macrobotanical samples from eight sites were examined. The 88 different lots examined contained 435 items. With the exception of a burned clay ball and an unknown item, the remaining 433 botanical samples contained 66 wood fragments. The remaining 367 specimens were either bulbs/corms or fragments of bulbs and corms.

Three bulb taxa, Allium sp., Camassia scilloides, and Erythronium sp. were identified in the macrobotanical samples. Two wood types were identified in the macrobotanical samples - oak and mesquite. Several samples from 41BR246 contained globose specimens that did not have layered bulb scales. Instead, examination in cross-section revealed a cortex-like structure, suggesting that they were tubers. These may be referable to a species of Pediomelum, but firm identification was not possible. 
Table C-1. Macrobotanical Samples from Camp Bowie Sites

\begin{tabular}{|c|c|c|c|c|c|c|c|}
\hline $\begin{array}{r}\text { Site } \\
(41 \mathrm{BR}\end{array}$ & Lot \# & Name & Common & Part & Count & Wt (g) & Size/Comments \\
\hline 65 & 22 & Camassia scilloides & Eastern Camas & Bulb & 1 & 0.2 & $10 \times 9$ \\
\hline 65 & 23 & Camassia scilloides & Eastern Camas & Bulb & 3 & 0.3 & $11 \times 9$ \\
\hline 65 & 23 & Camassia scilloides & Eastern Camas & Bulb & 5 & 0.7 & $10 \times 9$ \\
\hline 65 & 25 & Camassia scilloides & Eastern Camas & Bulb & 5 & 1.6 & $9 \times 8$ \\
\hline 65 & 26 & Camassia scilloides & Eastern Camas & Bulb & 3 & 0.2 & $11 \mathrm{X} 6+$ slag \\
\hline 65 & 29 & Camassia scilloides & Eastern Camas & Bulb & 2 & 0.3 & $15 \times 12$ \\
\hline 65 & 30 & Camassia scilloides & Eastern Camas & Bulb & 2 & 0.3 & No Measurement \\
\hline 65 & 34 & Camassia scilloides & Eastern Camas & Bulb & 1 & 0.3 & $15 \times 12$ \\
\hline 65 & 36 & Camassia scilloides & Eastern Camas & Bulb & 1 & 0.3 & $11 \times 10$ \\
\hline 65 & 38 & Camassia scilloides & Eastern Camas & Bulb & 2 & 0.2 & 12 X9+ slag \\
\hline 65 & 41 & Camassia scilloides & Eastern Camas & Bulb & 1 & 0.2 & $11 \times 9$ \\
\hline 65 & 43 & Camassia scilloides & Eastern Camas & Bulb & 1 & 0.2 & $10 \times 7$ \\
\hline 65 & 16 & Camassia scilloides & Eastern Camas & Bulb fragment & 1 & 0.2 & Fragments \\
\hline 65 & 21 & Indeterminable & & Bulb fragment & 2 & 0.1 & Fragments \\
\hline 65 & 23 & Camassia scilloides & Eastern Camas & Bulb fragment & 4 & 0.2 & $8 \times 7$ \\
\hline 65 & 29 & Indeterminable & & Bulb fragment & 6 & 0.5 & Fragments \\
\hline 65 & 30 & Camassia scilloides & Eastern Camas & Bulb fragment & 3 & 0.1 & $11 \times 9$ \\
\hline 65 & 32 & Camassia scilloides & Eastern Camas & Bulb fragment & 2 & 0.4 & $11 \mathrm{X} 8+$ slag \\
\hline 65 & 34 & Indeterminable & & Bulb fragment & 8 & 0.4 & Fragments \\
\hline 65 & 37 & Camassia scilloides & Eastern Camas & Bulb fragment & 5 & 0.2 & Fragments \\
\hline 65 & 17 & Quercus sp. & Oak & Wood & 2 & 0.3 & \\
\hline 65 & 17 & Indeterminable & & Wood & 2 & 0.1 & \\
\hline 65 & 32 & Indeterminable & & Wood & 3 & 0.2 & \\
\hline 65 & 39 & Quercus sp. & Oak & Wood & 2 & 0.1 & \\
\hline 65 & 43 & Indeterminable & & Wood & 6 & 0.1 & \\
\hline 87 & 35 & Indeterminable & & Bulb fragment & 1 & 0.2 & $11 \mathrm{X} 10$ \\
\hline 87 & 37 & Indeterminable & & Bulb fragment & 3 & 1.5 & $10 \times 9$ \\
\hline 87 & 39 & Indeterminable & & Bulb fragment & 2 & 0.1 & $8 \mathrm{X} 6$ \\
\hline 228 & 5 & Camassia scilloides & Eastern Camas & Bulb & 1 & 0.1 & $10 \times 7+$ slag \\
\hline 228 & 15 & Camassia scilloides & Eastern Camas & Bulb & 2 & 0.2 & Inner scales \\
\hline 228 & 17 & Camassia scilloides & Eastern Camas & Bulb & 3 & 0.4 & $11 \mathrm{X} 8+$ slag \\
\hline 228 & 18 & Camassia scilloides & Eastern Camas & Bulb & 3 & 0.3 & Inner scales \\
\hline 228 & 18 & Camassia scilloides & Eastern Camas & Bulb & 2 & 0.1 & Fragments \\
\hline 228 & 25 & Camassia scilloides & Eastern Camas & Bulb & 5 & 0.2 & Inner scales \\
\hline 228 & 27 & Camassia scilloides & Eastern Camas & Bulb & 5 & 0.2 & 11 X6 + slag \\
\hline 228 & 33 & Camassia scilloides & Eastern Camas & Bulb & 3 & 0.5 & $12 \times 10+$ slag \\
\hline 228 & 34 & Camassia scilloides & Eastern Camas & Bulb & 1 & 0.1 & $10 \mathrm{X} 8+$ slag \\
\hline 228 & 35 & Camassia scilloides & Eastern Camas & Bulb & 1 & 0.1 & $10 \mathrm{X} 7$ \\
\hline 228 & 52 & Camassia scilloides & Eastern Camas & Bulb & 1 & 0.2 & Fragments \\
\hline 246 & 20 & Indeterminate & & Bulb & 1 & & Fragments \\
\hline 246 & 32 & Indeterminate & & Bulb & 12 & 1.74 & $12 \times 7$ \\
\hline 246 & 36 & Indeterminate & & Bulb & 1 & & $10 \mathrm{X} 8$ \\
\hline 246 & 40 & Indeterminate & & Bulb & 2 & 0.4 & $\begin{array}{l}\text { 11X7; Thick outer cortex, } \\
\text { Pediomelum? }\end{array}$ \\
\hline
\end{tabular}


Table C-1. continued...

\begin{tabular}{|c|c|c|c|c|c|c|c|}
\hline $\begin{array}{c}\text { Site } \\
(41 \mathrm{BR} \quad) \\
\end{array}$ & Lot \# & Name & Common & Part & Count & Wt (g) & Size/Comments \\
\hline 246 & 41 & Indeterminate & & Bulb & 1 & 0.2 & $7 \times 7$ \\
\hline 246 & 45 & Indeterminate & & Bulb & 2 & 0.3 & $11 \mathrm{X} 8+$ slag \\
\hline 246 & 51 & Indeterminate & & Bulb & 2 & 0.8 & $12 \times 10+$ slag \\
\hline 246 & 54 & Indeterminate & & Bulb & 3 & 0.1 & No Measurement \\
\hline 246 & 56 & Indeterminate & & Bulb & 1 & 0.1 & Inner scales \\
\hline 246 & 56 & Indeterminate & & Bulb & 2 & 0.43 & $\begin{array}{l}\text { 8X7; Thick outer cortex, } \\
\text { Pediomelum? }\end{array}$ \\
\hline 246 & 57 & Indeterminate & & Bulb & 3 & 0.9 & $10 \mathrm{X} 8+$ slag \\
\hline 246 & 62 & Indeterminate & & Bulb & 1 & 0.2 & $9 \times 6$ \\
\hline 246 & 68 & Indeterminate & & Bulb & 1 & 0.2 & $\begin{array}{l}\text { 11X10; Thick outer cortex, } \\
\text { Pediomelum? }\end{array}$ \\
\hline 246 & 44 & Indeterminate & & Bulb+Frags & 4 & 0.1 & $\begin{array}{l}\text { 13X10; Thick outer corteX, } \\
\text { Pediomelum? }\end{array}$ \\
\hline 246 & 36 & Indeterminate & & Tuber & 3 & & $\begin{array}{l}\text { 9X9; Thick outer corteX, } \\
\text { Pediomelum? }\end{array}$ \\
\hline 246 & 38 & Indeterminate & & Tuber & 1 & 0.2 & $\begin{array}{l}\text { 10X9; Thick outer cortex, } \\
\text { Pediomelum? }\end{array}$ \\
\hline 246 & 44 & Indeterminate & & Unknown & 1 & & \\
\hline 246 & 48 & Quercus sp. & & Wood & 20 & 1.24 & \\
\hline 246 & 54 & Quercus sp. & & Wood & 1 & 0.1 & No Measurement \\
\hline 246 & 57 & Prosopis sp. & Mesquite & Wood & 8 & 0.5 & \\
\hline 246 & 61 & Prosopis sp. & Mesquite & Wood & 9 & 0.3 & \\
\hline 250 & 26 & Indeterminable & & Bulb & 6 & 1.4 & $9 \times 7$ \\
\hline 250 & 34 & Camassia scilloides & Eastern Camas & Bulb & 7 & 2.5 & $13 \times 11$ \\
\hline 250 & 34 & Indeterminable & & Bulb & 11 & 1.1 & Fragments \\
\hline 250 & 36 & Indeterminable & & Bulb & 2 & 0.4 & $13 \times 9$ \\
\hline 250 & 23 & Allium sp. & Onion & Bulb & 3 & 0.5 & $12 \times 9+$ slag \\
\hline 250 & 20 & Indeterminable & & Bulb & 2 & 0.9 & $13 X 11+$ slag \\
\hline 250 & 31 & Indeterminable & & Bulb fragment & 30 & 1.2 & 9 X8 + slag \\
\hline 250 & 31 & Indeterminable & & Bulb fragment & 30 & 1.8 & 9 X6 + slag \\
\hline 253 & 13 & Camassia scilloides & Eastern Camas & Bulb & 1 & 0.2 & $10 \mathrm{X} 9+$ fragments \\
\hline 253 & 47 & Indeterminable & & Bulb & 3 & 0.2 & Inner scales \\
\hline 253 & 17 & Indeterminable & & Bulb & 2 & 0.2 & $11 \mathrm{X} 9+$ fragments \\
\hline 253 & 28 & Camassia scilloides & Eastern Camas & Bulb & 6 & 1.2 & $12 \mathrm{X} 8$ \\
\hline 253 & 48 & Camassia scilloides & Eastern Camas & Bulb & 5 & 0.8 & $11 \mathrm{X} 8+$ slag \\
\hline 253 & 7 & Allium sp. & Onion & Bulb & 3 & 0.5 & $9 \times 8+$ slag \\
\hline 253 & 12 & Camassia scilloides & Eastern Camas & Bulb & 3 & 0.2 & $16 \times 14$ \\
\hline 253 & 50 & Allium sp. & Onion & Bulb & 3 & 0.4 & $11 \mathrm{X} 10$ \\
\hline 253 & 38 & Camassia scilloides & Eastern Camas & Bulb & 1 & 0.2 & Fragments \\
\hline 253 & 19 & Indeterminable & & Bulb & 3 & 0.8 & $8 \times 7+$ slag \\
\hline 253 & 34 & Indeterminable & & Bulb & 3 & 0.3 & $9 \mathrm{X} 8$ \\
\hline 253 & 45 & Indeterminable & & Bulb + fragment & 30 & 2.6 & $15 \times 7$ \\
\hline 253 & 47 & Indeterminable & & Bulb fragment & 25 & 2.3 & Fragments \\
\hline 253 & 17 & Indeterminable & & Bulb fragment & 3 & 0.2 & Fragments \\
\hline
\end{tabular}


Table C-1. continued...

\begin{tabular}{|c|c|c|c|c|c|c|c|}
\hline $\begin{array}{r}\text { Site } \\
(41 \mathrm{BR} \quad) \\
\end{array}$ & Lot \# & Name & Common & Part & Count & Wt (g) & Size/Comments \\
\hline 253 & 28 & Indeterminable & & Bulb fragment & 5 & 0.9 & Inner scales + fragments \\
\hline 253 & 45 & Indeterminable & & Bulb fragment & 1 & 0.1 & $9 \times 5+$ slag \\
\hline 253 & 46 & Camassia scilloides & Eastern Camas & Bulb fragment & 4 & 0.3 & $9 \times 6$ \\
\hline 253 & 30 & Camassia scilloides & Eastern Camas & Bulb fragment & 8 & 1.4 & $10 \times 9+$ fragments \\
\hline 253 & 24 & Indeterminable & & Bulb fragment & 1 & 0.1 & Fragments \\
\hline 420 & 26 & $\begin{array}{l}\text { Erythronium } \\
\text { mesochoreum }\end{array}$ & $\begin{array}{l}\text { Dog's-tooth } \\
\text { violet }\end{array}$ & Bulb & 1 & 0.3 & $11 \mathrm{X} 9+$ slag \\
\hline 420 & 15 & Indeterminable & & Bulb fragment & 2 & 0.2 & Fragments \\
\hline 420 & 22 & Indeterminable & & Bulb fragment & 2 & 0.2 & Fragments \\
\hline 420 & 26 & Indeterminable & & Bulb fragment & 2 & 0.1 & Fragments \\
\hline 420 & 11 & Indeterminable & & Bulb fragment & 1 & 0.3 & Fragments \\
\hline 420 & 24 & Non-botanical & & Clay ball & 1 & 2 & \\
\hline 493 & 092-06 & Indeterminate & & Bulb & 6 & 1.3 & $9 \times 9$ \\
\hline 493 & $095-05$ & Camassia scilloides & Eastern Camas & Bulb & 1 & 0.5 & $9 \times 5+$ slag \\
\hline 493 & 096-06 & Camassia scilloides & Eastern Camas & Bulb & 1 & 0.5 & No Measurement \\
\hline 493 & 096-04 & Indeterminate & & Bulb & 1 & 0.7 & $6 \times 5$ \\
\hline 493 & 099-03 & Indeterminate & & Bulb & 1 & 0.2 & No Measurement \\
\hline 493 & $101-05$ & Indeterminate & & Bulb & 6 & 1.9 & $15 \times 13$ \\
\hline 493 & $102-02$ & Indeterminate & & Bulb & 5 & 0.4 & $9 \times 8$ \\
\hline 493 & $103-06$ & Indeterminate & & Bulb & 1 & 0.2 & Thick outer leaf scale \\
\hline 493 & $108-07$ & Camassia scilloides & Eastern Camas & Bulb & 4 & 0.8 & $8 \times 6$ \\
\hline 493 & $109-07$ & Indeterminate & & Bulb & 1 & 0.4 & $14 X 11$ \\
\hline 493 & $102-02$ & Prosopis sp. & Mesquite & Wood & 5 & 0.2 & \\
\hline 493 & $109-07$ & Quercus sp. & & Wood & 3 & 0.1 & \\
\hline 493 & $110-07$ & Quercus sp. & & Wood & 3 & 0.3 & \\
\hline 493 & $119-07$ & Quercus sp. & & Wood & 2 & 0.1 & \\
\hline
\end{tabular}

\section{Flotation Samples}

Table C-2 presents the results of the 35 flotation samples from 16 sites. Many of the sites were represented by only two or three flotation samples. A volume of 51.5 liters of sediment were floated, with sample size averaging a shade less that 1.5 liters. Despite the diminutive size of the samples, they were quite productive. A total of 28 bulb fragments was recovered from six of the samples, and a mesquite seed was noted in sample 70 from 41BR478. The samples also contained mesquite, juniper, willow/ cottonwood, and oak wood charcoal fragments.

It is interesting to note that 17 percent of the flotation samples from the Camp Bowie sites contained fragments of charred bulbs. Bulb fragments and seeds were recovered at an average density of .57 fragments/liter, very high for central Texas sites. The preservation of plant resources is remarkable compared to results from other sites in Texas. Furthermore, this represents the first large-scale plant recovery effort in a decade that has been conducted from sites in the region.

\section{Site Descriptions}

\section{$41 B R 65$}

Seventy-three specimens from 17 lots were examined from this site. In addition, two flotation samples were examined. Small fragments of oak wood were noted in Lots 17 and 39, and juniper wood was recovered from Unit 7. Fifty-eight bulbs and fragments were identified in the macrobotanical samples, and a single bulb scale fragment was noted in flotation sample 22 from Unit 1. Bulb scale fragments were selected from Feature 1 for identification. Analysis of material from Lot 23 indicates that the bulbs are most likely 
Table C-2. Plant Remains from Flotation Samples

\begin{tabular}{|c|c|c|c|c|c|c|c|}
\hline $\begin{array}{c}\text { Site } \\
(41 \mathrm{BR}\end{array}$ & $\begin{array}{c}\text { Sample ID } \\
\text { (Lot \#) }\end{array}$ & Taxon & Common Name & Part & Count & Weight (g) & $\begin{array}{c}\text { Flotation Sample } \\
\text { Size (liter) }\end{array}$ \\
\hline 65 & 22 & Indeterminate & Indeterminate & Bulb & 1 & 0.2 & 1 \\
\hline 65 & 22 & Quercus sp. & Oak & Wood & 4 & 0.3 & \\
\hline 65 & 37 & Quercus sp. & Oak & Wood & 19 & 0.7 & 1.5 \\
\hline 65 & 37 & Juniperus sp. & Juniper & Wood & 4 & 0.2 & \\
\hline 87 & 29 & Indeterminate & Indeterminate & Bulb & 1 & 0.1 & 1.5 \\
\hline 87 & 29 & Quercus sp. & Oak & Wood & 9 & 0.2 & \\
\hline 87 & 39 & Indeterminate & Indeterminate & Wood & 8 & 0.1 & 1.5 \\
\hline 228 & 17 & Indeterminate & Indeterminate & Bulb & 12 & 0.5 & 1.5 \\
\hline 228 & 17 & Quercus sp. & Oak & Wood & 6 & 0.1 & \\
\hline 228 & 33 & Indeterminate & Indeterminate & Unknown & 6 & 0.7 & 1.5 \\
\hline 228 & 26 & Quercus sp. & Oak & Wood & 14 & 0.6 & 1.5 \\
\hline 228 & 30 & Quercus sp. & Oak & Wood & 3 & 0.1 & 1.5 \\
\hline 246 & 51 & Indeterminate & Indeterminate & Bulb & 12 & 0.5 & 1.5 \\
\hline 246 & 51 & Quercus sp. & Oak & Wood & 22 & 0.9 & \\
\hline 246 & 35 & Quercus sp. & Oak & Wood & 16 & 0.4 & 1.5 \\
\hline 250 & 32 & Indeterminate & Indeterminate & Wood & 12 & 1.3 & 1.5 \\
\hline 250 & 44 & Quercus sp. & Oak & Wood & 25 & 1.4 & 1.5 \\
\hline 250 & 44 & Prosopis sp. & Mesquite & Wood & 1 & 0.3 & \\
\hline 253 & 7 & Quercus sp. & Oak & Wood & 1 & 0.1 & 1.5 \\
\hline 253 & 17 & Quercus sp. & Oak & Wood & 17 & 0.1 & 1.5 \\
\hline 253 & 18 & Quercus sp. & Oak & Wood & 10 & 0.3 & 1.5 \\
\hline 253 & 30 & Salix sp. & Willow & Wood & 2 & 0.1 & 1.5 \\
\hline 253 & 30 & Quercus sp. & Oak & Wood & 10 & 0.2 & \\
\hline 415 & 35 & Quercus sp. & Oak & Wood & 1 & 0.1 & 1.5 \\
\hline 415 & 38 & Juniperus sp. & Juniper & Wood & 1 & 0.1 & 1.5 \\
\hline 420 & 15 & Indeterminate & Indeterminate & Wood & 3 & 0.1 & 1.5 \\
\hline 420 & 20 & Quercus sp. & Oak & Wood & 10 & 0.2 & 1.5 \\
\hline 433 & 31 & NPR & NPR & NA & $\mathrm{XX}$ & $\mathrm{XX}$ & 1.5 \\
\hline 433 & 6 & Quercus sp. & Oak & Wood & 14 & 0.4 & 1.5 \\
\hline 441 & 2 & Indeterminate & Indeterminate & Bulb & 1 & 0.1 & 1.5 \\
\hline 441 & 2 & Prosopis sp. & Mesquite & Wood & 13 & 0.3 & \\
\hline 441 & 7 & Indeterminate & Indeterminate & Wood & 3 & 0.1 & 1 \\
\hline 473 & 125 & Quercus sp. & Oak & Wood & 11 & 0.1 & 1.5 \\
\hline 473 & 130 & Quercus sp. & Oak & Wood & 8 & 0.2 & 1.5 \\
\hline 474 & 2 & Quercus sp. & Oak & Wood & 6 & 0.5 & 1.5 \\
\hline 474 & 4 & Quercus sp. & Oak & Wood & 2 & 0.2 & 1.5 \\
\hline 478 & 70 & Prosopis sp. & Mesquite & Seed & 1 & 0.1 & 1.5 \\
\hline 478 & 70 & Prosopis sp. & Mesquite & Wood & 4 & 0.3 & \\
\hline 478 & 73 & Quercus sp. & Oak & Wood & 12 & 0.2 & 1.5 \\
\hline 480 & 24 & Indeterminate & Indeterminate & Wood & 6 & 0.1 & 1.5 \\
\hline 492 & 42 & Quercus sp. & Oak & Wood & 4 & 0.1 & 1.5 \\
\hline 492 & 44 & Indeterminate & Indeterminate & Wood & 13 & 0.1 & 1.5 \\
\hline 493 & 109 & Indeterminate & Indeterminate & Bulb & 1 & 0.1 & 1.5 \\
\hline 493 & 109 & Quercus sp. & Oak & Wood & 12 & 0.3 & \\
\hline 493 & 116 & Quercus sp. & Oak & Wood & 12 & 0.4 & 1.5 \\
\hline
\end{tabular}


Camassia scilloides, or Eastern camas. Bulbs and bulb fragments examined from Lot 29, Feature 1, also were identified as Camassia scilloides. It appears that the oven at 41BR65 was primarily used for preparing Camassia scilloides, a plant with a wide geographic distribution throughout central and northeastern Texas. It is interesting that Eastern camas has not been found to grow in dense stands today.

\section{$41 B R 87$}

Material from this site consisted of six bulb fragments contained in three lots. A single stub preparation of a fragment from Lot 35 did not yield a positive identification. Flotation sample 29 yielded a single bulb scale and nine fragments of oak wood charcoal.

\section{$41 B R 228$}

Ten macrobotanical lots containing 27 specimens were examined with a light microscope. All of the material consisted of bulbs or fragments of bulbs. Of these samples, material from Lot 18, Feature 1, was selected for analysis. These specimens closely resemble reference material attributable to Eastern camas. Most of the material identified was from Feature 1, though a bulb was also recovered from Feature 4. Four flotation samples contained oak wood charcoal fragments, and 12 bulbs were recovered from flotation sample \#17.

\section{$41 B R 246$}

Bulb fragments were plentiful in the 16 macrobotanical lots examined from this site. Thirty-six bulbs and bulb fragments were present in 13 different lots. In addition, several tubers were detected in the samples. While I was unable to confirm the identification, they are similar in gross anatomy to reference material identified as Pediomelum hypogaea. Both mesquite and oak wood were also present. The two flotation samples analyzed contained 12 bulb fragments and oak wood charcoal.

\section{$41 B R 250$}

Six lots containing 91 specimens were examined from this site. All material was from Feature 1, the burned rock midden, and 91 bulbs and bulb fragments were identified. Material from two different lots were selected for detailed analysis. Interestingly, these turned out to be two different taxa. Lot 34 contained Camassia scilloides, and Lot 23 samples were Allium sp. Wood fragments from flotation sample \#44, Unit 4 , contained both oak and mesquite wood charcoal.

\section{$41 B R 253$}

Fifteen lots from this site contained a total of 110 bulbs and bulb fragments. These lots were recovered from three different features, with bulbs present in the two burned rock middens as well as in Feature 6, located immediately outside of Feature 2, a burned rock oven at this site. Twenty-eight bulbs were attributable to Camassia scilloides. Six bulbs very closely resemble reference material from Allium sp. Four flotation samples contained 40 oak and willow wood charcoal fragments.

\section{$41 B R 415$}

No macrobotanical samples were submitted from this site. The two flotation samples produced oak and juniper wood charcoal.

\section{$41 B R 420$}

Five lots containing eight specimens were examined from this site. Lot 24 contained a fired clay ball. Other material from the site was either unidentifiable or contained the remains of bulbs. At least one of these bulbs closely resembles samples of Erythronium sp., dog's-tooth violet. Although the use of this plant is reported in ethnographies, this is the first known example of dog's-tooth violet from an archaeological site in North America. Two flotation samples contained a few wood charcoal fragments, some of which were identified as oak.

\section{$41 B R 433$}

No macrobotanical samples were submitted from this site. One of the two flotation samples lacked any recovery. The other contained oak wood charcoal.

\section{$41 B R 441$}

No macrobotanical samples were submitted from this site. One of the two flotation samples contained mesquite wood charcoal as well as a single indeterminate bulb fragment.

\section{$41 B R 473$}

No macrobotanical samples were submitted from this site. The two flotation samples produced oak wood charcoal.

\section{$41 B R 474$}

No macrobotanical samples were submitted from this site. The two flotation samples produced oak wood charcoal. 


\section{$41 B R 478$}

No macrobotanical samples were submitted from this site. One of the two flotation samples from this site produced oak wood charcoal. The second flotation sample (\#70) produced mesquite wood charcoal and a single carbonized mesquite seed.

\section{$41 B R 480$}

No macrobotanical samples were submitted from this site. The single flotation sample produced carbonized wood.

\section{$41 B R 492$}

No macrobotanical samples were submitted from this site. Both of the flotation samples produced carbonized wood, with oak charcoal being identified in one sample.

\section{$41 B R 493$}

Twenty-seven bulbs or bulb fragments were identified in nine of the 11 macrobotanical lots examined from this site. Six specimens from Lots 95, 96, and 108 were identified as Camassia scilloides. Sample 102 contained mesquite wood charcoal, and oak wood charcoal was recovered from samples 109, 110, and 119. Both of the flotation samples from this site contained oak wood charcoal, and one of the samples (\#109) produced a bulb fragment identified as Camassia scilloides.

\section{Discussion and Ethnobotanical Overview}

Five potentially important plant resources were noted in the samples. At least three of these resources, Eastern camas, wild onion, and mesquite, likely contributed a significant portion to the Archaic foraging diet in the region during certain seasons or in certain weather regimes. Two other resources, dog's-tooth violet and an unidentified tuberous plant (possibly prairie turnip), may also have been a significant seasonal component of the diet.

\section{Fruit}

\section{Mesquite (Prosopis glandulosa Torr.)}

There are two types of natural resources, unfailing and facultative crops. Unfailing crops are plants that can always be depended upon to produce year after year independent of local, short-term climatic conditions such as drought or freeze. Mesquite is the most widespread of all unfailing crops in the hot lowlands of southwestern North America, and as such, it is one of the most important natural resources of the region (Felger 1977:154).

Although arboreal legume wood was identified from the Corn Creek sites (Dering 1997), it was not possible to absolutely assign the material to mesquite. This is the first positive identification of mesquite from the region of northcentral Texas. Based on the evidence from 41BR246, 41BR250, 41BR441, 41BR478, and 41BR493 in addition to the evidence from the Corn Creek sites, it is apparent that mesquite was sufficiently widespread in the Cross Timbers and Prairies to be utilized for both fuel and food.

I make this assertion based on a seed/pod fragment and wood charcoal for two reasons. First, when data from rockshelters and open sites are compared from the same region, it is clear the mesquite pods or seeds are under represented at open sites. For example, at a study conducted at Tonto National Monument, a pueblo structure sheltered by a rock overhang, mesquite occurred in 59 percent of the flotation samples. In open sites in sight of the Tonto National Monument, mesquite was recorded in only 1.6 percent of 617 samples processed from open sites in the basin. Likewise at Hinds Cave (41VV456), mesquite seeds/pod fragments occurred in 80 percent of the processed samples and by contrast is seldom encountered at open sites (Dering et al. 2000). Because mesquite pods are not usually exposed to fire or flame until the pod is reduced to flour (Bell and Castetter 1937), the chance of mesquite seeds/pods surviving at open sites is much lower than for many other food resources. Therefore, I take the presence of charred mesquite seed and wood to be a sign of mesquite exploitation. The fact that mesquite is considered an unfailing resource, one on which groups throughout the Southwest relied upon, provides more evidence that it may have been quite important in the study region.

\section{Bulbs}

The ethnobotanical references note several preparation methods for each of the bulb resources, including eating them raw, boiling them, and pit-baking them. They are referred to as condiments or spices, as side-dishes, and as staples. This study is concerned primarily with the use of bulbs as staples. By staple I mean a food resource that contributes a significant number of calories to the diet at least on a seasonal basis. Although several methods may be used to process bulbs, pit-baking is the best method for cooking them as a staple. Most bulbs contain chemicals that 
discourage ingestion by predators (Johns 1990). These chemicals must be removed in order to consume bulbs in any quantity, and the best method for processing bulbs for bulk consumption is pit-baking (Wandsnider 1997). In each case where I have been able to locate them, the following ethnobotanical references discuss each resource in the context of pit-baking. Although several refer to the same species of plant, none of these references come from Texas, primarily because ethnohistoric references that actually name the root food are focused outside the state. Many of these observations were made at reservations or public lands in Oklahoma, New Mexico, and Arizona. An excellent example of the type of observation recorded in Texas is provided by Cabeza de Vaca, writing of foragers in southern Texas: "Their principal food is roots of two or three kinds, for which they search throughout the land. The roots are very bad and cause people who eat them to swell up. It takes two days to roast them and many of them are very bitter. On top of this, they are very difficult to dig" (Favata and Fernandez 1993:81-82). Encapsulated in this account is the poisonous aspect of root foods, the need to process them using heat for long time periods, and the work involved in processing them. Unfortunately, no clue regarding the identity of these roots is given.

\section{Eastern Camas \\ (Camassia scilloides (Raf.) Cory)}

Eastern camas has been identified from seven sites in Texas, in addition to the sites in the current study. The genus Camassia contains about five species, three of which have recorded food value (Gould 1942). Although there is a large body of literature addressing the use of some camas species (Camassia quamash or Camassia leichtlinii) in the northwest, there is little ethnographic information available for Eastern camas. I have been able to locate two records of Eastern camas use, both from Oklahoma, and both by Comanche. In a visit to the Comanche Indian Reservation near Indiahoma, Oklahoma, Carlson and Jones (1940:528) recorded the description of Eastern camas use. There is no mention of fire, nor of any detailed preparation method. They did not, however, observe use of the plant or collect it. A more detailed description from near the TexasOklahoma border is provided by Sternberg (1931:223). He made the observation in 1882, and noted that the Comanches excavated a pit "...five feet deep and three in diameter and kindled a fire at the bottom, using at least a cord of wood..." (Sternberg 1931:223). There is no mention of a rock heating element, but he does say that "...the ashes were scraped out, and the wall plastered with a mortar of mud, over which green grass was thickly strewn to prevent the bulbs from burning..." (Sternberg 1931:223). This description raises the issue of the accuracy of even eyewitness accounts. The description of a cord of wood is in line with both eyewitness descriptions of earth oven use, and with experiments, however, the pit measurements are too small. A cord of wood measures roughly $4 \times 4 \times 8$ feet $\left(128 \mathrm{ft}^{3}\right)$, and the pit was described as being three-feet wide and five-feet deep, about $35 \mathrm{ft}^{3}$. Granted, wood is usually stacked in a pile at least five-feet above a pit, and that would double the fuel-load volume to about $70 \mathrm{ft}^{3}$. The lack of a rock heating element is not very credible. In the 23 or so earth ovens I have built, I have never been able to heat the ground to a temperature that would require lining the pit with moist packing material. Packing material is necessary only when a rock heating element is present, and Sternberg describes the use of packing material to prevent ignition of the food load. Inconsistencies in ethnohistoric descriptions of plant processing are often encountered. The problems with Sternberg's description of the process do not negate its value. To the contrary, much of the account is credible, especially the use of fire and the size of the fuel load. It is clear from the description that Sternberg arrived at the camp after the oven was fired and the food placed in it. He most likely missed the rock element because it is difficult to see much detail in a smoldering pit.

\section{Wild Onion (Allium sp.)}

In addition to the Camp Bowie sites, wild onion is reported from four open sites in Texas. Onion has also been noted at Hinds Cave (41VV456) and in most rockshelters located in the Lower Pecos region (Irving 1966). Ethnographic and historic records of wild onion use are widespread across North America. Although none of these records come from Texas, it is an important center of diversity and dispersal of the genus Allium, and 12 of the 17 or so species of Allium noted in North America occur in Texas (Ownbey 1950). Therefore, most of the ethnographic observations refer to onion species that occur in Texas. Narrowing the search to references that refer to pit-baking or roasting onions (i.e., bulk processing), at least nine ethnohistoric groups are mentioned, including the Pomo, Ramah Navajo, Paiute, and Gosiute, as well as several groups in the Pacific northwest (Dering 2002a).

Barret (1952:89) notes that the Pomo of northern California baked onions in an underground oven. The Surprise Valley Paiute collected Allium in large quantities, two to five sacks at a time. They dug a pit and built a fire of unspecified size 
to which they added small stones. The food load was placed in the oven, covered with grass and earth, and left overnight (Kelly 1933:102).

\section{Dog's-tooth Violet (Erythronium sp.)}

The identification of dog's-tooth violet at 41BR420 marks the first occurrence of this plant from an archaeological site. Dog's-tooth violet is a lesser-known bulb used as a food source in North America. The best record of use comes from observations of the Thompson in southwestern British Columbia. The Thompson understood the raw bulbs of dog's-tooth violet to be poisonous, and they pit-baked the bulbs in order to remove the poison.

\section{False Garlic (Nothoscordum bivalve (L.) Britt.)}

Reported in Grimes County in the eastern edge of the Post Oak Savannah, false garlic is an interesting case because there are no references to its use. Its widespread distribution throughout most of Texas and the densities in which it grows make false garlic a prime candidate for a geophyte staple. It is erroneously reported as poisonous, yet I have eaten many of the bulbs. When pit-baked, it is virtually tasteless. At $212 \mathrm{kcal} / 100 \mathrm{~g}$, the caloric content of false garlic is somewhat lower than other bulbs or agave, which average $270 \mathrm{kcal} / 100 \mathrm{~g}$ or higher. Yet false garlic grows in such high density throughout the Post Oak Savannah that it may have been an important seasonal staple.

\section{Prairie Turnip, Prairie Peanut, Snakeroot, Scurfpea (Pediomelum spp.)}

I mention this root food not because I have a positive identification of it, but because I have recognized the presence of a tuber-like structure in the macrobotanical and flotation samples from 41BR246. In addition, tubers resembling Pediomelum were reported from the Richland Creek, Joe Pool Lake, and Cooper Lake sites (Crane 1989:G6). The analysts, however, were unable to confirm a positive identification. It is interesting that tubers resembling species of Pediomelum are being recovered from several archaeological sites in north and central Texas.

One reason I am reticent to give a positive identification is that I have been unable to recognize an anatomical signature or set of characteristics that would distinguish one tuber from another. The second reason is that ethnography and experiment do not make a solid functional connection between the preparation of scurfpea and earth oven use. All references to the use of the plant note that the tuber is encased in a thick husk which is peeled off before consumption. One reference notes that the tuber is roasted, but many note that it can be consumed raw. The husk may serve as an effective barrier for the tuber, and the need for poisonous compounds to protect the food storage organ may be not so great. Nevertheless, the plant was important to many Plains Indians, including the Cheyenne, Dakota, Lakota, Pawnee, and Ponca (Dering 2002a).

\section{Conclusion}

We now have a record of at least five different bulb taxa identified from 18 archaeological sites in central/ southwestern Texas-Eastern camas, wild onion, false garlic, dog's-tooth violet, and rain lily (Table C-3). Plant bulbs have been recovered from well-described burned rock features at Hinds Cave (41VV456), at the Wilson-Leonard site (41WM235), the Jonas Terrace site (41ME29), Blockhouse Creek (41WM632), the Honey Creek site (41MS32), Horn Shelter (41BQ4), Rice's Crossing (41WM815), and the Geophyte Site (41CV595) located on Fort Hood in Coryell County (Dering 1996, 1999, 2000a, 2000b). This is a significant body of data, considering what we understood about the botany of burned rock middens a decade ago.

In fact, the idea that root foods contributed significantly to the Archaic diet of the Southern Plains periphery is relatively new. A list of botanical remains compiled in 1988 for a symposium on burned rock midden archaeology included only seeds (Howard 1991:65). Although bulb fragments had been noted in dry deposits of rockshelters from the Lower Pecos region for 25 years (Irving 1966), and a cache of charred bulbs had been recovered from Horn Shelter in the 1970s (Watt 1978), analysts overlooked them in flotation samples from open sites until the early 1990s. The eventual recognition of bulbs in flotation samples from open sites is attributable to two factors. First, the analysis of flotation samples was finally emphasized in Texas during the 1990s. More significantly, identification was aided by the discovery of several complete, charred bulbs which were pointcollected from the Wilson-Leonard site. Most of the bulbs were intact, allowing identification of at least the general plant structure. At the normal magnifications under which macrobotanical work is conducted ( $8 \mathrm{X}$ to $75 \mathrm{X}$ ) it was difficult to tell what part of the plant the small bulb fragments constitute, and so for years they were overlooked. 


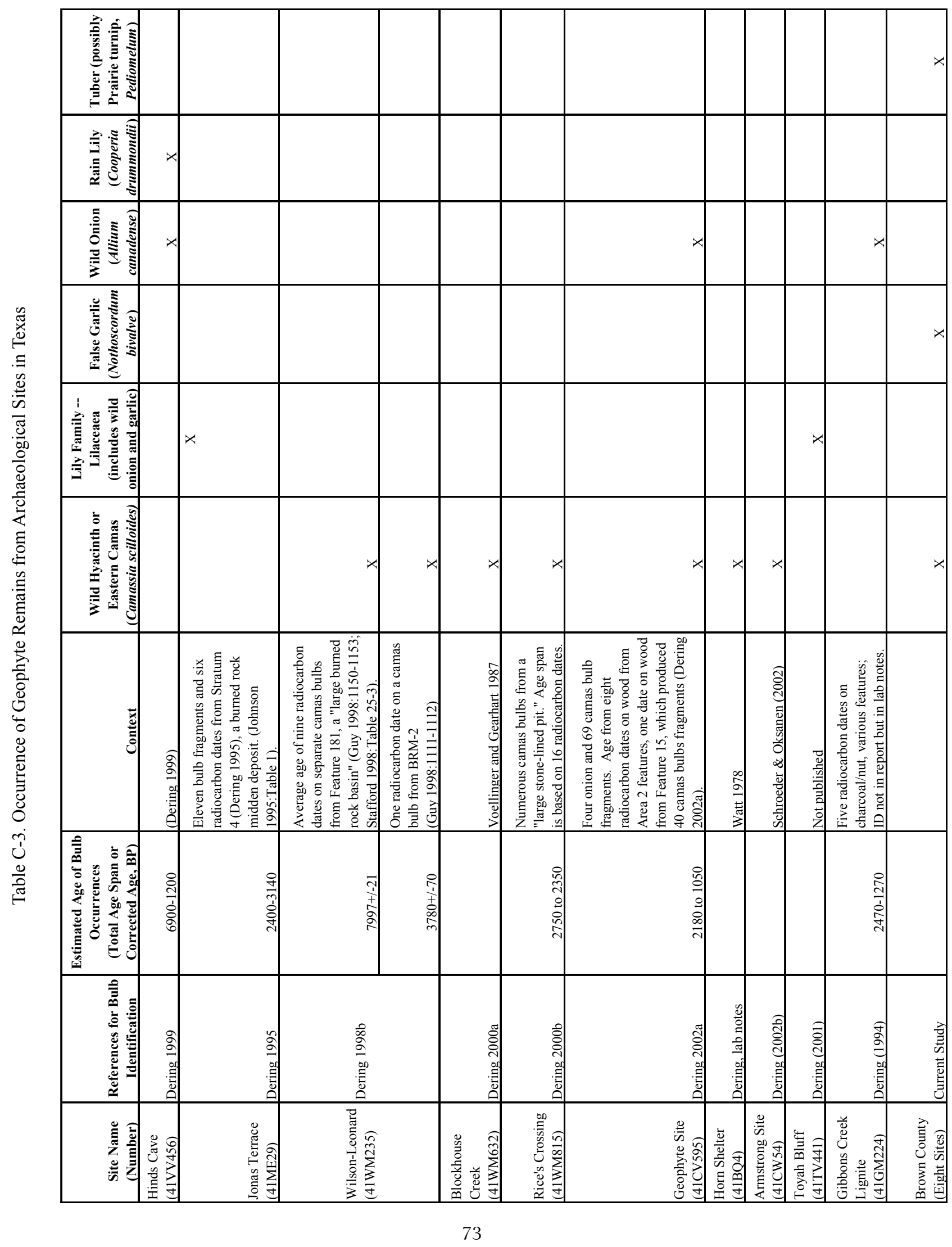


Adding to the difficulty of identification is the fact that recovery of plant food remains from burned rock midden sites is very inconsistent. For example, 460 macroplant samples and 76 flotation samples from the Wilson-Leonard site (41WM235) yielded very little information regarding plant food resources. Only three of the 76 flotation samples contained identifiable charred plant remains. Despite the dismal recovery, nine charred bulbs were point-collected from a single feature, and AMS assays from each of them yielded dates that clustered around 8,000 BP. At Blockhouse Creek sites in Williamson County, 62 unproductive samples (no identifiable charred plant remains) were recorded during the analysis of 120 flotation samples from a series of Late Archaic and Late Prehistoric burned rock middens, yet five of the samples contained plant bulb fragments.

It was not until 11 charred, complete bulbs were pointcollected from burned rock features at the Wilson-Leonard site that a breakthrough in recognition was achieved. Yet recognizing that the Wilson-Leonard plant specimens were bulbs failed to provide us with many clues at to their specific identity. No keys or reference collections existed for the identification of charred plant bulbs. As a result, a method had to be designed that actually provided the analyst with an identification of the specimen. Because the method involves microscopic examination of small fragments of the bulb scale surface, it is now possible to recognize and identify small fragments of bulbs which were previously overlooked.

In the most comprehensive study of earth oven cooking on the Edwards Plateau to date, Black and Creel (1997:294) asserted that burned rock middens represent accumulations resulting from a rather diverse set of human activities, earth oven cooking being one of them. Ovens were utilized primarily for cooking either the vegetative, food-storing stems of sotol or yucca, prickly pear, bulb- or tuber-bearing plants such as onion, or certain green fruits, such as prickly pear tunas, and perhaps even acorns. Prior to that argument, various researchers argued that burned rock middens represented the remains of some unknown plant "veggie baking" (Prewitt 1976) or nut processing activities such as acorn processing sites (Creel 1986).

The Wilson-Leonard site also demonstrated the time depth for the utilization of geophytic resources and earth oven processing. A total of 11 bulbs was point-collected from the matrix of two burned rock features. Radiocarbon assays were secured directly from 10 of these bulbs (Table C-3). Burned Rock Midden 2, a Late Archaic feature, contained a bulb that was dated to $3780 \pm 70$ BP. Feature 181, an Early Archaic feature, contained several bulbs from which nine assays were secured, averaging 7997 BP (Stafford 1998:1054). Thanks to these dates, archaeologists had to consider the possibility that geophyte remains could be potentially recovered from any sizable burned rock feature dating to any time period in the Holocene.

Once complete bulbs had been examined, analysts began to recognize bulb fragments, which occur much more commonly than entire bulbs (Dering 2000a). Pattern recognition and increased flotation efforts have proven fruitful, and bulb fragments and complete bulbs have now been recovered from several sites located on the southern and eastern edges of the Edwards Plateau. Sites located at the border between the Edwards Plateau and the Blackland Prairie and tributary streams that flow from the escarpment into the prairie, have yielded remains of bulbs. It is no longer unusual to find bulbs in sites across the Edwards Plateau, and there is now a pattern emerging along the eastern and northern periphery of the plateau that suggests the intense preparation of bulbs, including wild onion and Eastern camas, in earth ovens.

The current study provides significant findings for the study of land use in the Cross Timbers and Prairies. Although an earlier study of four burned rock middens included two sites from the northern Edwards Plateau in McCulloch County, on Corn Creek just south of the Colorado River (Black 1997:169), very few flotation samples were available for processing. The sites had been excavated in the 1970s by another crew, and Black was unable to revisit and excavate the Corn Creek sites (Black 1997:175). The current findings from the Camp Bowie sites provide solid evidence for the importance of geophytes to the subsistence strategies of the region.

The recovery of close to 400 bulbs and bulb fragments from 16 sites on Camp Bowie provides unequivocal evidence that the primary focus of earth oven use in the region is the processing of geophytes. It also provides us with a significant body of data for evaluating land-use practices in the region. Collectively, the data indicate that geophytes were much more important to the Southern Plains foragers of the Archaic and Late Prehistoric periods than previously thought. 


\section{References Cited}

Barret, S. A.

1952 Material Aspects of Pomo Culture: Part One. Bulletin of the Public Museum of the City of Milwaukee 20:1-260.

Bell, W. H., and E. F. Castetter

1937 Ethnobiological Studies in the American Southwest: V. The Utilization of Mesquite and Screwbean by the Aborigines in the American Southwest. The University of New Mexico Bulletin 5(2). University of New Mexico Press Albuquerque, New Mexico.

Black, S. L.

1997 Scenarios of Midden Accumulation. In Hot Rock Cooking on the Greater Edwards Plateau: Four Burned Rock Midden Sites in West Central Texas, edited by S. L. Black, L. W. Ellis, D. G. Creel, and G. T. Goode, pp. 140-150. Studies in Archeology 22. Texas Archeological Research Laboratory, The University of Texas at Austin.

Black, S. L., and D. G. Creel

1997 The Central Texas Burned Rock Midden Reconsidered. In Hot Rock cooking on the Greater Edwards Plateau: Four Burned Rock Midden Sites in West Central Texas, edited by S. L. Black, L. W. Ellis, D. G. Creel, and G. T. Goode, pp. 446-515. Studies in Archeology 22. Texas Archeological Research Laboratory, The University of Texas at Austin.

Black, S. L., L. W. Ellis, D. G. Creel, and G. T. Goode

1997 Hot Rock Cooking on the Greater Edwards Plateau: Four Burned Rock Midden Sites in West Central Texas (two volumes). Studies in Archeology 22. Texas Archeological Research Laboratory, The University of Texas at Austin; Texas Department of Transportation Environmental Affairs Department, Archeology Studies Program, Report 2.

Carlson, G. G., and V. H. Jones

1940 Some Notes on Uses of Plants by the Comanche Indians. Papers of the Michigan Academy of Science, Arts, and Letters 25:517-542.

Crane, $\mathrm{C}$,

1989 Archaeobotanical Remains. In Archeological Investigations at Cooper Lake: 1987 Season, Appendix G, edited by R. Moir, D. McGregor, and D. Jurney. Archaeology Research Program, Southern Methodist University. Dallas, Texas.

Creel, D.

1986 A Study of Prehistoric Burned Rock Middens in West Central Texas. Unpublished Ph. D. dissertation. The University of Arizona, Tucson.

De Hertogh, A. A., and M. Le Nard

1993 Botanical Aspect of Flower Bulbs. In The Physiology of Flower Bulbs, edited by A. A. De Hertogh and M. Le Nard, pp. 7-20. Elsevier Press. Amsterdam. 
Dering, $P$.

1994 Plant Remains from 41GM224, Grimes County, Texas. In Excavations at site 41GM224 in the Gibbons Creek Lignite Mine permit 38A area, Grimes County, Texas, by R. Rogers. Appendix D. Espey, Huston and Associates, Inc. Austin, Texas.

1996 Utilization of Geophytes on the Southern Plains: Identification and Assessment of a Once Archaeologically "Invisible" Resource. Paper Presented at the Sixty-first Annual Meeting of the Society for American Archaeology, April 10-14, 1996, New Orleans, Louisiana

1997 Macrobotanical Remains. In, Hot Rock Cooking on the Greater Edwards Plateau: Four Burned Rock Midden Sites in West Central Texas, by S. L. Black, pp. 573-600. Studies in Archeology 22. Texas Archeological Research Laboratory, The University of Texas at Austin.

1998a Plant Remains from the Richard Beene Site (41BX831): Implications for Holocene Climatic Change in SouthCentral Texas. Draft on file at the Center for Ecological Archaeology, Texas A\&M University.

1998b Carbonized Plant Remains. In, Wilson-Leonard: An 11,000-year Archeological Record of Hunter-Gatherers in Central Texas. Volume V: Special Studies, assembled and edited by M. B. Collins, pp. 1609-1636. Studies in Archeology 31. Texas Archeological Research Laboratory, The University of Texas at Austin.

1999 Earth-Oven Plant Processing in Archaic Period Economies: An Example from a Semi-Arid Savannah in SouthCentral North America. American Antiquity 64(4):659-674.

2000a Plant Remains from the Blockhouse Creek Sites, Williamson County, Texas. Ms. on file at the Center for Ecological Archaeology, Texas A\&M University. College Station, Texas.

2000 b Plant Remains from Rice's Crossing (41WM815), Williamson County, Texas. Ms. on file at the Center for Ecological Archaeology, Texas A\&M University. College Station, Texas.

2001 Macrobotanical Analysis of Samples from 41TV441, the Toyah Bluff Site. Ms. on file at the Archaeobotanical Laboratory, Texas A\&M University, College Station, Texas.

2002a An Annotated Bibliography Geophyte Use with Emphasis on Texas Species. Ms. on file, Department of Anthropology, Texas A\&M University. College Station, Texas.

2002b Appendix F: Plant Remains from the Armstrong Site. In Data Recovery at the Armstrong Site (41CW54) Caldwell County, Texas Volume 1: Background, Methods, and Site Context, by E. A. Schroeder and E. R. Oksanen, pp. 265-276. PPA Cultural Resources Report Number 0284.

Dering, P., O. K. Davis, and G. L. Fox

2000 Botanical Remains. In Archeological Investigation of Rooms 15 and 16 at the Upper Cliff Dwelling (AZ U:8:48 [ASM]), Tonto National Monument, by G. L. Fox, pp. 197-232. Western Archeological and Conservation Center, National Park Service. United States Department of the Interior Publications in Anthropology 73. Tucson, Arizona.

Favata, M. A., and J. B. Fernandez (translators)

1993 The Account: Alvar Nunez Cabeza de Vaca's Relacion. Arte Publico Press. Houston, Texas.

Felger, R. S.

1977 Mesquite in Indian Cultures of Southwestern North America. In Mesquite: Its Biology in Two Desert Ecosystems, edited by B. B. Simpson, pp. 150-176. Dowden, Hutchinson, and Ross, Inc., Stroudsburg, Pennsylvania.

Gould, F.

1942 A Systematic Treatment of the Genus Camassia Lindl. American Midland Naturalist. 28(3):712-742.

Guy, J.

1998 Analysis of Cultural and Noncultural Features. In Wilson-Leonard: An 11,000-year Archeological Record of Hunter-Gatherers in Central Texas. Volume IV: Special Studies, assembled and edited by M. B. Collins, pp. 1067-1208. Studies in Archeology 31. Texas Archeological Research Laboratory, The University of Texas at Austin. 
Howard, M.

1991 Burned Rock Midden Excavations, Hearths and Botanical Remains. In The Burned Rock Middens of Texas: An Archeological Symposium, edited by T. R. Hester, pp. 45-69. Studies in Archeology 13. Texas Archeological Research Laboratory, The University of Texas at Austin.

Irving, R. S.

1966 The Preliminary Analysis of Plant Remains from Six Amistad Reservoir Sites. In A Preliminary Study of the Paleoecology of the Amistad Reservoir Area, edited by D. A. Story and V. M. Bryant, Jr., pp 61-90. Texas Archeological Salvage Project, The University of Texas at Austin.

Johns, T.

1990 With Bitter Herbs They Shall Eat It: Chemical Ecology and the Origins of Human Diet and Medicine. The University of Arizona Press. Tucson, Arizona.

Johnson, L., Jr.

1995 Past Cultures and Climates at Jonas Terrace, 41ME29, Medina County, Texas. Office of the State Archeologist, Report 40. Texas Department of Transportation and Texas Historical Commission, Austin.

Kelly, I.

1933 Ethnography of the Surprise Valley Paiute. University of California Publications In American Archaeology and Ethnography 31:67-210.

Martin, A. C., and W. D. Barkley

1961 Seed Identification Manual. University of California Press, Berkeley.

Ownbey, M.

1950 The Genus Allium in Texas. Research Studies of the State College of Washington 28(4):181-222.

Panshin and de Zeuw

1979 Textbook of Wood Technology, Volume 1. Timber Press. Corvallis, Oregon.

Prewitt, E. R.

1976 The Rogers Springs Site: 1974 Investigations. Unpublished manuscript on file, Texas Archeological Research Laboratory, The University of Texas at Austin.

Stafford, T. W., Jr.

1998 Radiocarbon Chronostratigraphy. In Wilson-Leonard: An 11,000-year Archeological Record of Hunter-Gatherers in Central Texas. Volume IV: Archeological Features and Technical Analyses, assembled and edited by M. B. Collins, pp. 1039-1066. Studies in Archeology 31. Texas Archeological Research Laboratory, The University of Texas at Austin.

Schroeder E. A., and E. R. Oksanen

2002 Data Recovery at the Armstrong Site (41CW54) Caldwell County, Texas Volume 1: Background, Methods, and Site Context. PPA Cultural Resources Report Number 0284.

Sternberg, C. H.

1931 The Life of a Fossil Hunter. Jensen Printing Company. San Diego, California. 
Thoms, A. V.

1989 The Northern Roots of Hunter-Gatherer Intensification: Camas and the Pacific Northwest. Unpublished Ph. D. dissertation, Department of Anthropology, Washington State University, Pullman.

Turner, N. J., L. Thompson, M. T. Thompson, and A. Z. York

1990 Thompson Ethnobotany: Knowledge and Usage of Plants by the Thompson Indian of British Columbia. Royal British Columbia Museum. Victoria, B.C.

Voellinger, L. R., and R. L. Gearhart, II

1987 Mitigation of Impacts at Three Burned Rock Midden Sites in the Block House Creek Development, Williamson County, Texas. Espey, Huston \& Associates, Inc., Austin, Texas.

Wandsnider, L.

1997 The Roasted and the Boiled: Food Composition and Heat Treatment with Special Emphasis on Pit-Hearth Cooking. Journal of Anthropological Archaeology 16:1-48.

Watt, F.

1978 Radiocarbon Chronology of Sites in the Central Brazos Valley. Bulletin of the Texas Archeological Society 49:111-138. 
Appendix D

Mussel Shell Analyses 


\section{Appendix D: $\quad$ Mussel Shell Analyses}

\section{Glenn A. Goodfriend}

Table D-1 list identifications for 94 samples submitted from archaeological sites at Camp Bowie, Brown County, Texas. The majority of the shell was highly fragmentary, though most of the poorly preserved samples could be identified through comparison to complete specimens. Some of the pieces were too fragmentary to identify with any reasonable level of confidence - these are designated by "?".
Table D-2 presents the A/I ratios and Asp/Glu ratios of mollusks reflecting two species of the genus Quadrula. Two modern, live-collected samples from Texas were obtained from the Smithsonian mollusk collection. These were used to establish a baseline for the original amino acid composition.

Table D-1. Selected Mussel Shell Identifications from Camp Bowie Sites

\begin{tabular}{|c|c|c|c|c|}
\hline Site 41BR & Lot No. & Unit & Level & Species \\
\hline 65 & $24-2$ & 6 & 2 & Ap \\
\hline 65 & $29-4-\mathrm{A}$ & 6 & 3 & $\mathrm{Ap}$ \\
\hline 65 & 29-4-B & 6 & 3 & $\mathrm{Qa}$ \\
\hline 65 & 41-2 & 6 & 8 & $\mathrm{Ap}$ \\
\hline 65 & $25-3$ & 7 & 4 & $\mathrm{Qa}$ \\
\hline 65 & $34-3$ & 7 & 7 & $\mathrm{Qh}$ \\
\hline 87 & $22-4$ & 1 & 4 & $\mathrm{Qh}$ \\
\hline 87 & $29-5$ & 1 & 6 & $\mathrm{Qa}$ \\
\hline 87 & $36-5$ & 2 & 5 & $\mathrm{Qa}$ \\
\hline 87 & $37-4$ & 2 & 6 & $\mathrm{Ct}$ \\
\hline 228 & $07-06$ & 1 & 2 & $\mathrm{Qh}$ \\
\hline 228 & 08-05-A & 1 & 3 & $\mathrm{Ap}$ \\
\hline 228 & 08-05-B & 1 & 3 & $\mathrm{Ap}$ \\
\hline 228 & $25-02$ & 3 & 6 & $\mathrm{Ct}$ \\
\hline 228 & 51-04-A & 8 & 7 & $\mathrm{Qh}$ \\
\hline 228 & 51-04-B & 8 & 7 & $\mathrm{Qh}$ \\
\hline 228 & $57-03$ & 9 & 3 & $\mathrm{Qh}$ \\
\hline 228 & 46-03-A & 9 & 5 & $\mathrm{Qh}$ \\
\hline 228 & 46-03-B & 9 & 5 & $\mathrm{Qa}$ \\
\hline 228 & 175-02 & ST 90 & 4 & $\mathrm{Ap}$ \\
\hline 246 & $75-03$ & $215 \mathrm{n} / 338 \mathrm{e}$ & 10 & $\mathrm{Tv}$ \\
\hline 246 & $51-05$ & $219 n / 336 e$ & 11 & $\mathrm{Ap}$ \\
\hline 246 & 56-03-A & $219 n / 336 e$ & 12 & $\mathrm{Qa}$ \\
\hline 246 & 56-03-B & $219 n / 336 e$ & 12 & $\mathrm{Qa}$ \\
\hline 246 & $100-03$ & $219 n / 336 e$ & 13 & $\mathrm{Qa}$ \\
\hline 246 & $67-04$ & $219 n / 336 e$ & 14 & $\mathrm{Ap}$ \\
\hline 246 & $26-01$ & $220 \mathrm{n} / 336 \mathrm{e}$ & 5 & $\mathrm{Pp}$ \\
\hline 246 & 40-06-A & $220 \mathrm{n} / 336 \mathrm{e}$ & 8 & $\mathrm{Tv}$ \\
\hline 246 & 40-06-B & $220 \mathrm{n} / 336 \mathrm{e}$ & 8 & $\mathrm{Pp}$ \\
\hline 246 & 61-02 & $220 n / 336 e$ & 14 & $\mathrm{Ap}$ \\
\hline 246 & 0 & Midden Base & & $\mathrm{Pp}$ \\
\hline 250 & $10-03$ & 1 & 3 & $\mathrm{Ap}$ \\
\hline 250 & $09-02$ & 3 & 3 & $?$ \\
\hline 250 & $08-03$ & 4 & 3 & $\mathrm{Ap}$ \\
\hline 250 & $40-1$ & 4 & 9 & $\mathrm{Ap}$ \\
\hline 250 & 43-2 & 4 & 11 & $\mathrm{Ap}$ \\
\hline
\end{tabular}


Table D-1. continued...

\begin{tabular}{|c|c|c|c|c|}
\hline Site 41BR & Lot No. & Unit & Level & Species \\
\hline 250 & $34-03$ & 8 & 8 & $\mathrm{TV}$ \\
\hline 253 & $13-02$ & 1 & 4 & $\mathrm{Ct}$ \\
\hline 253 & $57-1$ & 2 & 4 & $\mathrm{Qa}$ \\
\hline 253 & $6-02$ & 6 & 3 & $\mathrm{Ap}$ \\
\hline 253 & $30-2$ & 6 & 6 & $\mathrm{Qh}$ \\
\hline 253 & $37-3-\mathrm{A}$ & 6 & 8 & $\mathrm{Qh}$ \\
\hline 253 & $37-3 \mathrm{~B}$ & 6 & 8 & Qh \\
\hline 415 & $35-4$ & 2 & 3 & Qh \\
\hline 415 & $38-3$ & 2 & 4 & $\mathrm{Qh}$ \\
\hline 415 & $16-3$ & 3 & 3 & $\mathrm{Ap}$ \\
\hline 415 & $29-2$ & 3 & 6 & $\mathrm{Qa}$ \\
\hline 415 & $33-3-A$ & 8 & 2 & $\mathrm{Qh}$ \\
\hline 415 & $33-3-B$ & 8 & 2 & $\mathrm{Ap}$ \\
\hline 415 & $34-2$ & 8 & 3 & $\mathrm{Ct}$ \\
\hline 415 & $44-2$ & ST 15 & 6 & Qh \\
\hline 415 & $71-2$ & ST 32 & 3 & $\mathrm{Qa}$ \\
\hline 420 & $7-2$ & 3 & 3 & $\mathrm{Pp}$ \\
\hline 433 & $27-7-A$ & 3 & 4 & $\mathrm{Qh}$ \\
\hline 433 & $27-7-B$ & 3 & 4 & $\mathrm{Qh}$ \\
\hline 433 & $31-2-A$ & 3 & 5 & $\mathrm{Qh}$ \\
\hline 433 & $31-2-B$ & 3 & 5 & $\mathrm{Qa}$ \\
\hline 433 & 29-6-A & 4 & 4 & $?$ \\
\hline 433 & 29-6-B & 4 & 4 & Qh \\
\hline 433 & $33-2-A$ & 4 & 5 & $\mathrm{Qh}$ \\
\hline 433 & $33-2-\mathrm{B}$ & 4 & 5 & $\mathrm{Ap}$ \\
\hline 473 & $135-1$ & $285 n / 136 e$ & 9 & $\mathrm{Ap}$ \\
\hline 473 & $133-2$ & $288 \mathrm{n} / 136 \mathrm{e}$ & 5 & $\mathrm{TV}$ \\
\hline 473 & $138-2-A$ & $288 \mathrm{n} / 136 \mathrm{e}$ & 7 & $\mathrm{Qh}$ \\
\hline 473 & 138-2-B & $288 \mathrm{n} / 136 \mathrm{e}$ & 7 & $\mathrm{TV}$ \\
\hline
\end{tabular}

\begin{tabular}{|c|c|c|c|c|}
\hline Site 41BR & Lot No. & Unit & Level & Species \\
\hline 478 & $71-02$ & $104 n / 338 \mathrm{e}$ & 7 & $\mathrm{Ap}$ \\
\hline 478 & $72-03$ & $104 \mathrm{n} / 338 \mathrm{e}$ & 8 & $\mathrm{Qh}$ \\
\hline 478 & $67-03$ & $104 n / 339 e$ & 4 & $\mathrm{Ct}$ \\
\hline 478 & 79-03 & $104 \mathrm{n} / 341 \mathrm{e}$ & 4 & $\mathrm{Qa}$ \\
\hline 478 & $81-03$ & $104 n / 341 \mathrm{e}$ & 6 & $\mathrm{Qh}$ \\
\hline 478 & $85-02$ & $104 \mathrm{n} / 341 \mathrm{e}$ & 8 & $\mathrm{Qh}$ \\
\hline 478 & $49-02$ & ST 15 & 6 & $?$ \\
\hline 480 & $13-7-\mathrm{A}$ & 5 & 2 & Qh \\
\hline 480 & $13-7-B$ & 5 & 2 & $\mathrm{Qh}$ \\
\hline 480 & $25-3$ & 5 & 3 & $\mathrm{Qh}$ \\
\hline 492 & $50-5$ & 1 & 13 & $?$ \\
\hline 492 & $19-2$ & 2 & 4 & $\mathrm{Pp}$ \\
\hline 492 & $48-3-A$ & 2 & 12 & $?$ \\
\hline 492 & $48-3-\mathrm{B}$ & 2 & 12 & $?$ \\
\hline 493 & $107-2$ & $111 \mathrm{n} / 215 \mathrm{e}$ & 8 & Qh \\
\hline 493 & $108-2$ & $111 \mathrm{n} / 215 \mathrm{e}$ & 9 & $?$ \\
\hline 493 & $110-2-A$ & $111 \mathrm{n} / 215 \mathrm{e}$ & 11 & $\mathrm{Ap}$ \\
\hline 493 & 110-2-B & $111 \mathrm{n} / 215 \mathrm{e}$ & 11 & $\mathrm{Qa}$ \\
\hline 493 & $104-7$ & $112 \mathrm{n} / 215 \mathrm{e}$ & 8 & $\mathrm{TV}$ \\
\hline 493 & $111-2$ & $112 \mathrm{n} / 215 \mathrm{e}$ & 9 & $\mathrm{Ap}$ \\
\hline 493 & $86-2$ & $115 n / 215 \mathrm{e}$ & 5 & $\mathrm{Qa}$ \\
\hline 493 & $93-2$ & $115 \mathrm{n} / 215 \mathrm{e}$ & 7 & $\mathrm{Pp}$ \\
\hline 493 & 119-2-A & $115 \mathrm{n} / 215 \mathrm{e}$ & 8 & $\mathrm{Ap}$ \\
\hline 493 & 119-2-B & $115 \mathrm{n} / 215 \mathrm{e}$ & 8 & $\mathrm{Ap}$ \\
\hline 493 & $95-2$ & $115 \mathrm{n} / 215 \mathrm{e}$ & 8 & $\mathrm{Ap}$ \\
\hline 493 & $96-2$ & $115 \mathrm{n} / 215 \mathrm{e}$ & 9 & $\mathrm{Ap}$ \\
\hline 493 & $100-2$ & $115 \mathrm{n} / 215 \mathrm{e}$ & 12 & $\mathrm{Ap}$ \\
\hline 493 & $102-5$ & $115 \mathrm{n} / 215 \mathrm{e}$ & 13 & $\mathrm{Qh}$ \\
\hline 493 & $103-2$ & $115 \mathrm{n} / 215 \mathrm{e}$ & 14 & $\mathrm{Qh}$ \\
\hline
\end{tabular}

Key:

$\mathrm{Ap}=$ Amblema plicata $($ Say)

$\mathrm{Ct}=$ Cyrtonaias tampicoensis (Lea)

$\mathrm{Pp}=$ Potamilus purpuratus (Lam.)

$\mathrm{Qa}=$ Quadrula apiculata (Say)

$\mathrm{Qh}=$ Quadrula houstonensis (Lea)

$\mathrm{Tv}=$ Tritogonia verrucosa (Rafin.) 
Table D-2. A/I ratios and Asp/Glu ratios for Quadrula from Camp Bowie Sites

\begin{tabular}{|c|c|c|c|c|c|c|}
\hline Lab number & Site & Lot & Species & A/I Ratio & Asp/Glu & Comment \\
\hline CJ-16 & 0 & 1 & $\mathrm{Qa}$ & 0.008 & 1.9800 & modern \\
\hline CJ-17 & 0 & 2 & $\mathrm{Qh}$ & 0.0099 & 2.1600 & modern \\
\hline CH-798 & 65 & $34-3$ & $\mathrm{Qh}$ & 0.6700 & 0.5700 & heated \\
\hline $\mathrm{CH}-827$ & 65 & 29-4B & $\mathrm{Qa}$ & 0.0470 & 1.8000 & \\
\hline CH-799 & 87 & $22-4$ & $\mathrm{Qh}$ & 0.0740 & 1.6400 & \\
\hline CH- 828 & 87 & $29-5$ & $\mathrm{Qa}$ & 0.0200 & 1.5700 & \\
\hline $\mathrm{CH}-802$ & 228 & $46-03 \mathrm{~A}$ & $\mathrm{Qh}$ & 0.8530 & 0.4600 & heated \\
\hline CH-803 & 228 & 51-04A & $\mathrm{Qh}$ & 0.7910 & 0.3800 & heated \\
\hline CH-800 & 228 & $7-6$ & $\mathrm{Qh}$ & 0.2610 & 1.4600 & \\
\hline CH-801 & 228 & $57-03$ & $\mathrm{Qh}$ & 0.1950 & 1.5900 & \\
\hline CH-804 & 228 & 51-04B & $\mathrm{Qh}$ & 0.1490 & 1.6400 & \\
\hline CH-829 & 228 & $46-03 \mathrm{~B}$ & $\mathrm{Qa}$ & 0.1040 & 1.8300 & \\
\hline CH-830 & 246 & 56-03A & $\mathrm{Qa}$ & 0.0860 & 1.8500 & \\
\hline CH-831 & 246 & 56-03B & $\mathrm{Qa}$ & 0.0540 & 2.0300 & \\
\hline CH-807 & 253 & $37-3 \mathrm{~A}$ & $\mathrm{Qh}$ & 0.3950 & 0.8400 & heated \\
\hline CH-806 & 253 & $37-3 \mathrm{~B}$ & $\mathrm{Qh}$ & 0.0860 & 1.7900 & \\
\hline CH-805 & 253 & $30-2$ & $\mathrm{Qh}$ & 0.0600 & 1.9100 & \\
\hline $\mathrm{CH}-832$ & 253 & $57-1$ & $\mathrm{Qa}$ & 0.0510 & 2.1600 & \\
\hline CH-833 & 415 & $71-2$ & $\mathrm{Qa}$ & 0.1660 & 1.7900 & \\
\hline CH-810 & 415 & $38-3$ & $\mathrm{Qh}$ & 0.1610 & 1.6500 & \\
\hline CH-811 & 415 & $44-2$ & $\mathrm{Qh}$ & 0.1370 & 1.7100 & \\
\hline CH-808 & 415 & $33-3 \mathrm{~A}$ & $\mathrm{Qh}$ & 0.1280 & 1.6300 & \\
\hline CH-809 & 415 & $35-4$ & $\mathrm{Qh}$ & 0.1080 & 1.6700 & \\
\hline CH-812 & 433 & $27-7 \mathrm{~B}$ & $\mathrm{Qh}$ & 0.2280 & 1.5400 & \\
\hline CH-814 & 433 & $29-6 \mathrm{~B}$ & Qh & 0.1620 & 1.4200 & \\
\hline CH-815 & 433 & $31-2 \mathrm{~A}$ & $\mathrm{Qh}$ & 0.1500 & 1.5500 & \\
\hline CH-816 & 433 & $33-2 \mathrm{~A}$ & $\mathrm{Qh}$ & 0.1360 & 1.5400 & \\
\hline CH-813 & 433 & $27-7 \mathrm{~A}$ & $\mathrm{Qh}$ & 0.1210 & 1.5800 & \\
\hline CH-817 & 473 & $138-2 \mathrm{~A}$ & $\mathrm{Qh}$ & 0.0630 & 1.7200 & \\
\hline CH-834 & 478 & $79-03$ & $\mathrm{Qa}$ & 0.5460 & 1.0100 & heated \\
\hline CH-818 & 478 & $81-03$ & $\mathrm{Qh}$ & 0.1240 & 1.5200 & \\
\hline $\mathrm{CH}-820$ & 478 & $85-02$ & Qh & 0.1190 & 1.7100 & \\
\hline CH-819 & 478 & $72-03$ & $\mathrm{Qh}$ & 0.1090 & 1.7900 & \\
\hline $\mathrm{CH}-822 \mathrm{a}$ & 480 & $13-7 \mathrm{~A}$ & $\mathrm{Qh}$ & 0.1340 & 1.6200 & \\
\hline $\mathrm{CH}-822 \mathrm{~b}$ & 480 & $13-7 \mathrm{~A}$ & $\mathrm{Qh}$ & 0.1280 & 1.5900 & \\
\hline $\mathrm{CH}-821$ & 480 & 13-7B & $\mathrm{Qh}$ & 0.1100 & 1.6300 & \\
\hline $\mathrm{CH}-823$ & 480 & $25-3$ & $\mathrm{Qh}$ & 0.0840 & 1.7800 & \\
\hline $\mathrm{CH}-825$ & 493 & $102-5$ & $\mathrm{Qh}$ & 0.0690 & 1.9200 & \\
\hline CH-824 & 493 & $107-2$ & $\mathrm{Qh}$ & 0.0460 & 1.8400 & \\
\hline CH-826 & 493 & $103-2$ & $\mathrm{Qh}$ & 0.0420 & 2.1400 & \\
\hline $\mathrm{CH}-835$ & 493 & $110-2 \mathrm{~B}$ & $\mathrm{Qa}$ & 0.0400 & 2.0300 & \\
\hline
\end{tabular}


Appendix E

\section{Recovered Projectile Points}




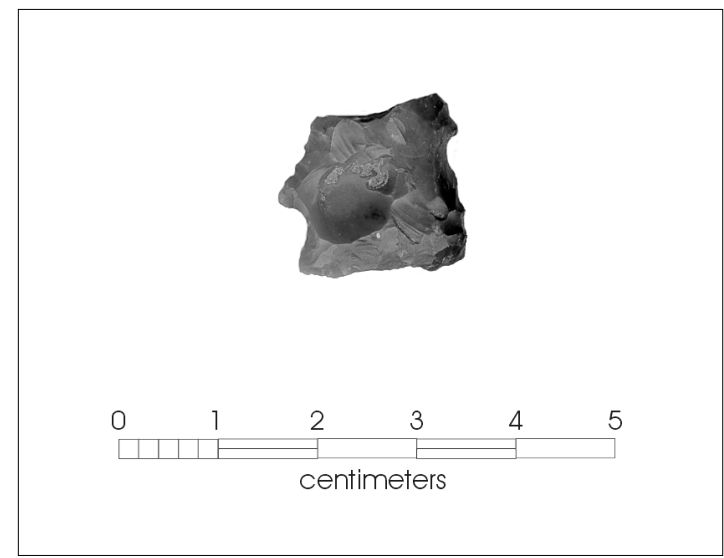

Figure E-1. Projectile point recovered from 41BR65; UI \#1, surface.

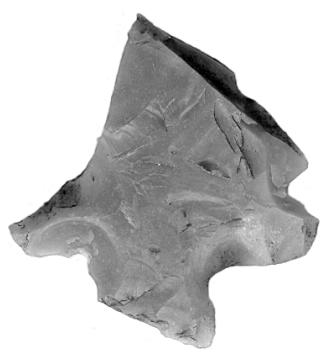

a

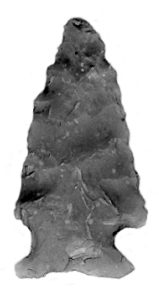

b

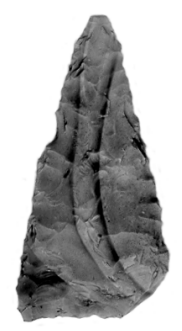

C

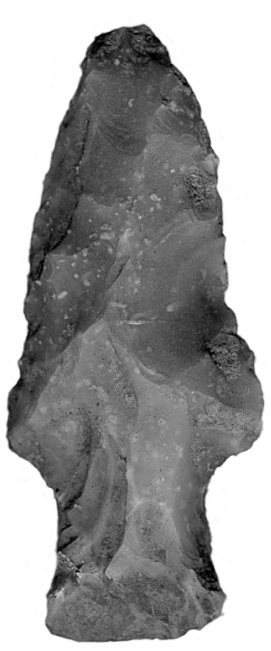

d

\begin{tabular}{l|llll}
0 & 1 & 2 & 3 & 4
\end{tabular}

Figure E-2. Projectile points recovered from 41BR87: (a) Unit 6, Level 2; (b) Unit 3, Level 2; (c) Unit 8, Level 2; (d) Shovel Test 29, Level 1. 


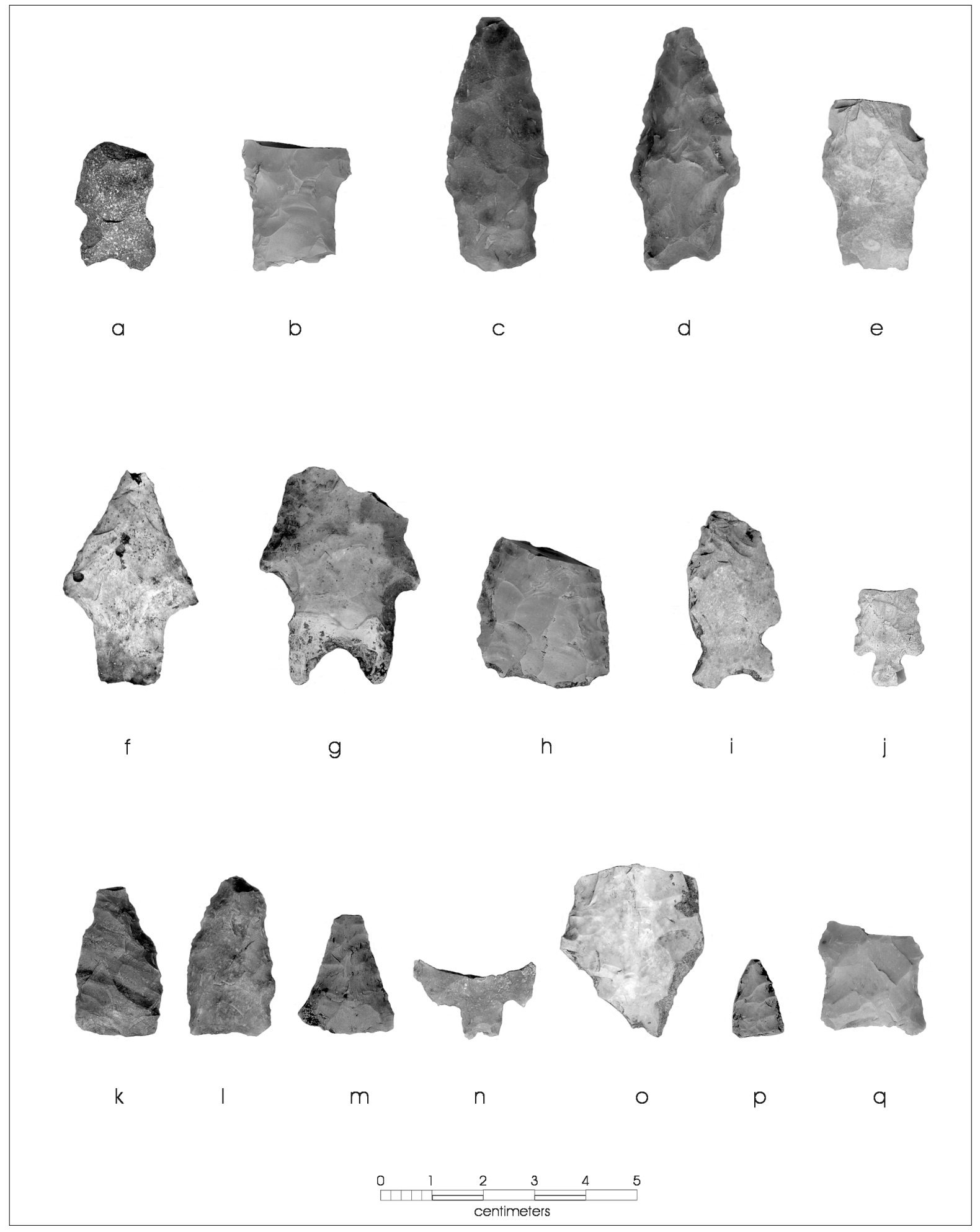

Figure E-3. Projectile points recovered from 41BR228: (a) Unit 7, Level 3; (b) Unit 7, Level 1; (c) Unit 3, Level 6; (d) UI \#1, surface; (e) Collection Area \#2, surface; (f) Shovel Test 72, Level 3; (g) Unit 9, Level 7; (h) Unit 3, Level 1; (i) Unit 8, Level 5; (j) UI \#2, surface; (k) Unit 4, Level 2; (l) Unit 4, Level 2; (m) Unit 4, Level 2; (n) Unit 7, Level 3; (o) Unit 7, Level 3; (p) Unit 1, Level 2; (q) Unit 7, Level 1. 


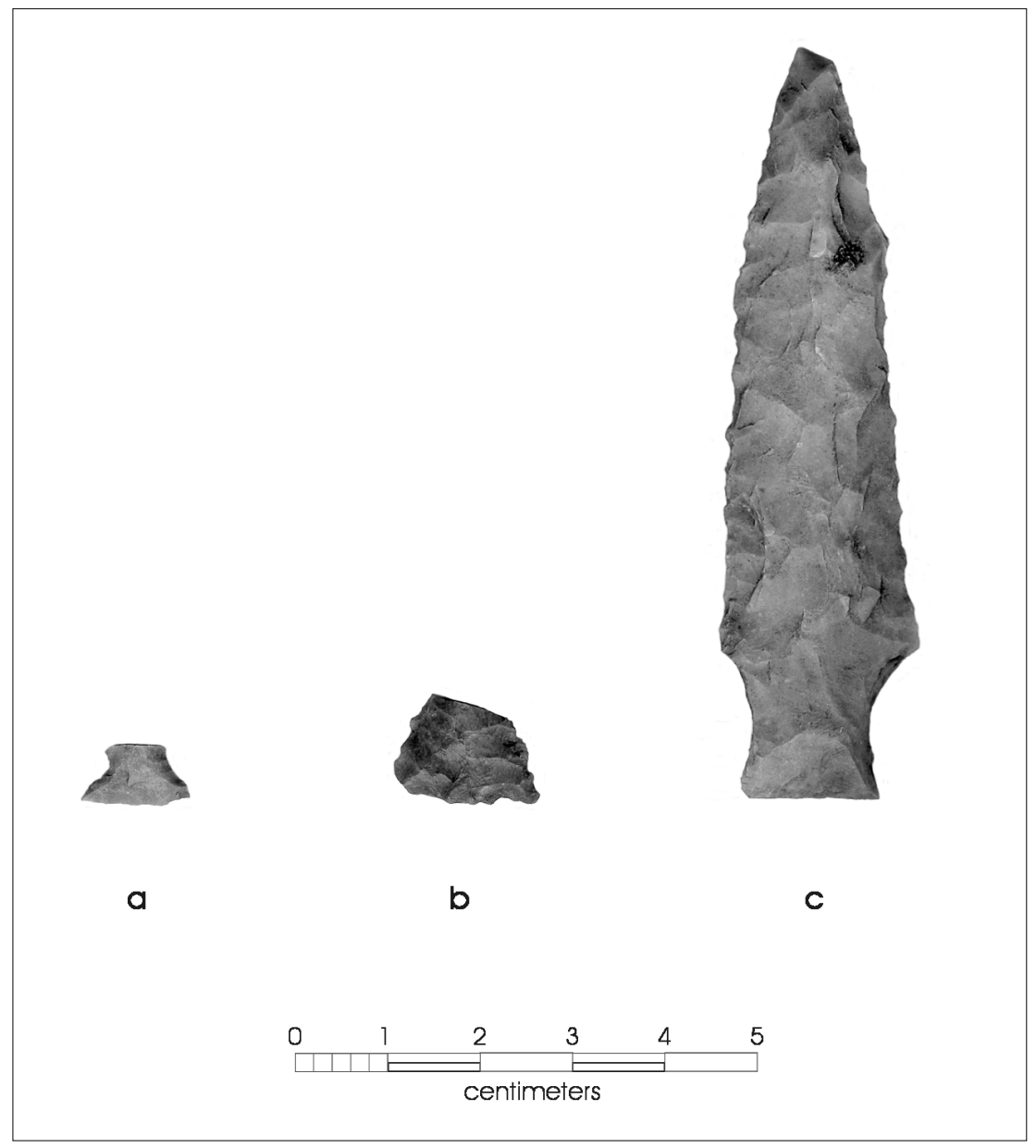

Figure E-4. Projectile points recovered from 41BR246: (a) Unit 3, Level 3; (b) Unit 3, Level 3; (c) Shovel Test 38, Level 2. 


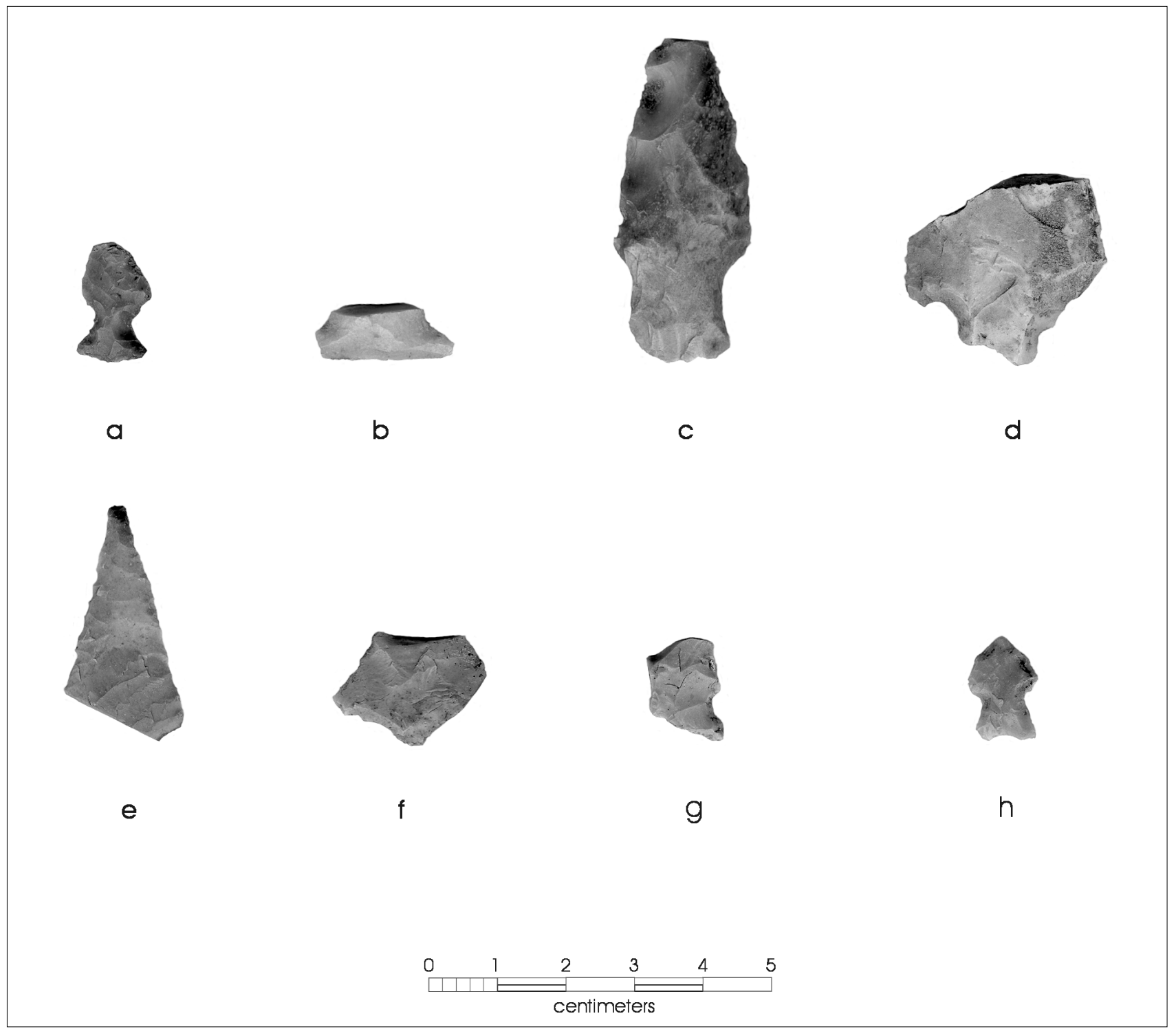

Figure E-5. Projectile points recovered from 41BR250: (a) Unit 4, Level 9; (b) Collection Area \#2, surface; (c) UI \#2, surface; (d) Collection Area \#2, surface; (e) Unit 1, Level 2; (f) Collection Area \#4, surface; (g) Collection Area \#1, surface; (h) Collection Area \#4, surface. 


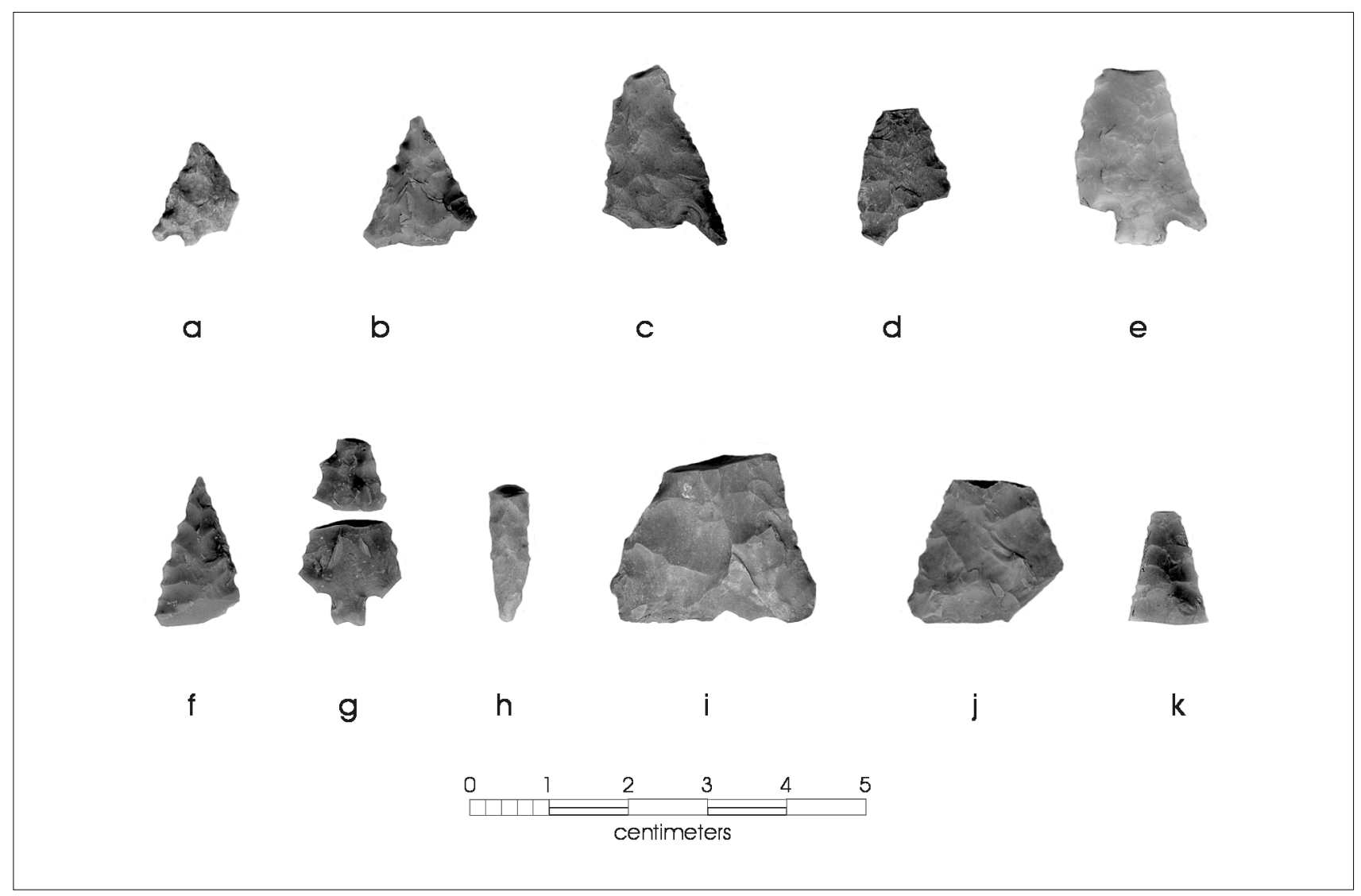

Figure E-6. Projectile Points recovered from 41BR253: (a) UI \#5, surface; (b) Unit 8, Level 1; (c) Unit 8, Level 1; (d) Collection Area \#1, surface; (e) Unit 9, Level 4; (f) Shovel Test 39, Level 5; (g) Shovel Test 58, Level 2; (h) Collection Area \#2, surface; (i) Collection Area \#1, surface; (j) Collection Area \#1, surface; (k) Shovel Test 57, Level 1.

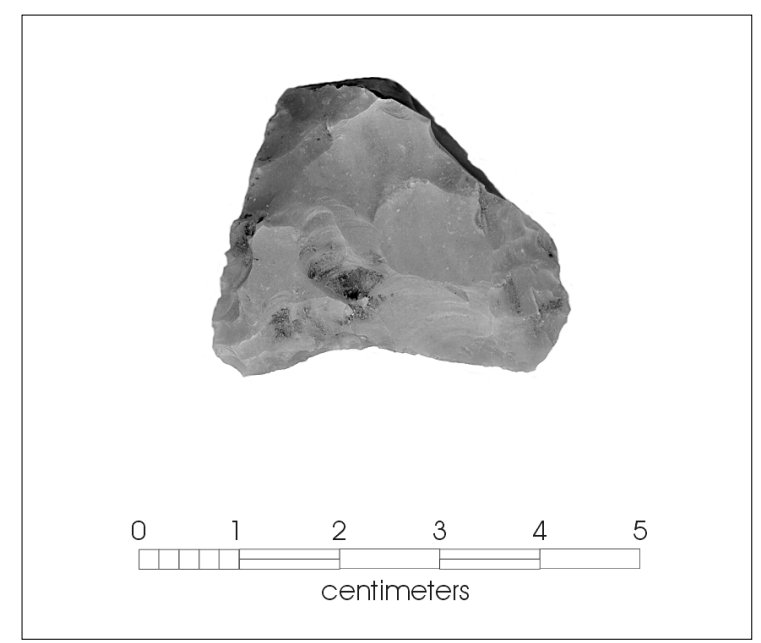

Figure E-7. Projectile point recovered from 41BR261; UI \#1, surface. 


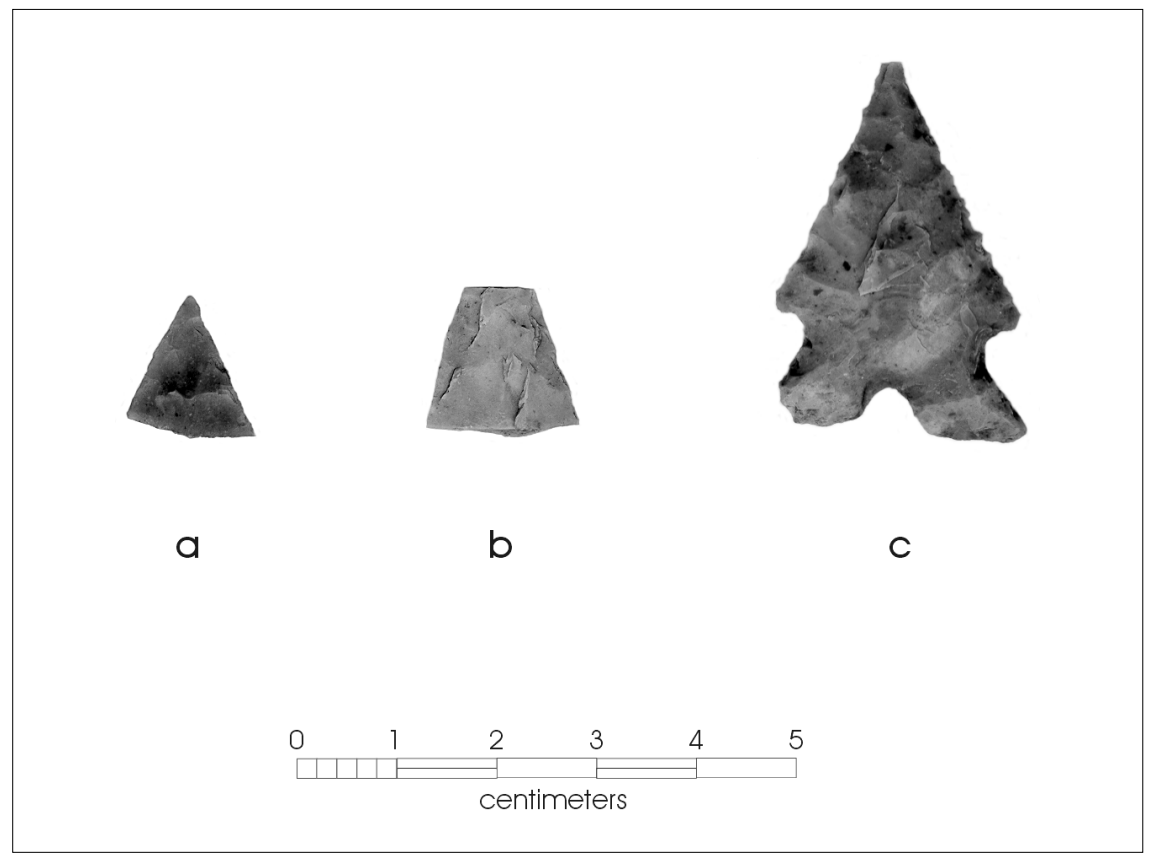

Figure E-8. Projectile points recovered from 41BR420: (a) Unit 1, Level 6; (b) Unit 2, Level 3; (c) Unit 3, Level 6.

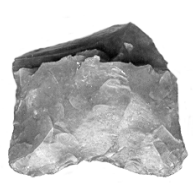

a

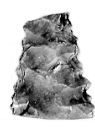

b

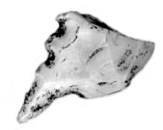

C

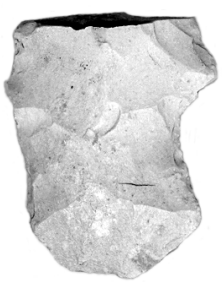

d

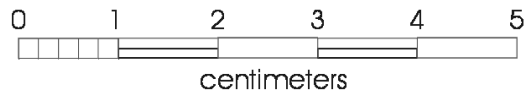

Figure E-9. Projectile points recovered from 41BR433: (a) Shovel Test 27, Level 1; (b) Unit 2, Level 4; (c) Unit 3, Level 2; (d) Unit 6, Level 2. 


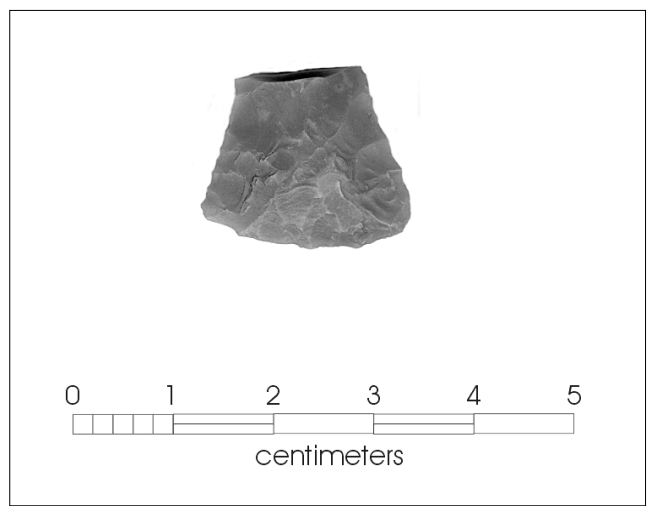

Figure E-10. Projectile point recovered from 41BR441; Collection Area \#1, surface.

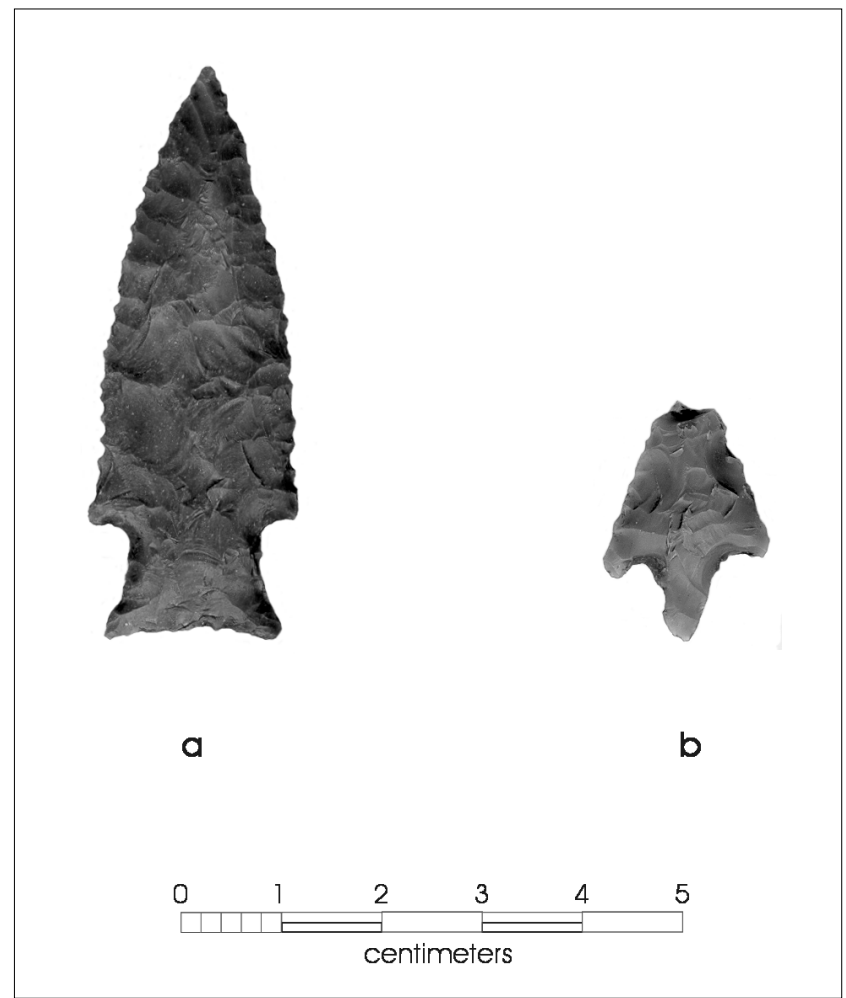

Figure E-11. Projectile points recovered from 41BR473: (a) Unit 1, Level 3; (b) Unit 1, Level 4. 


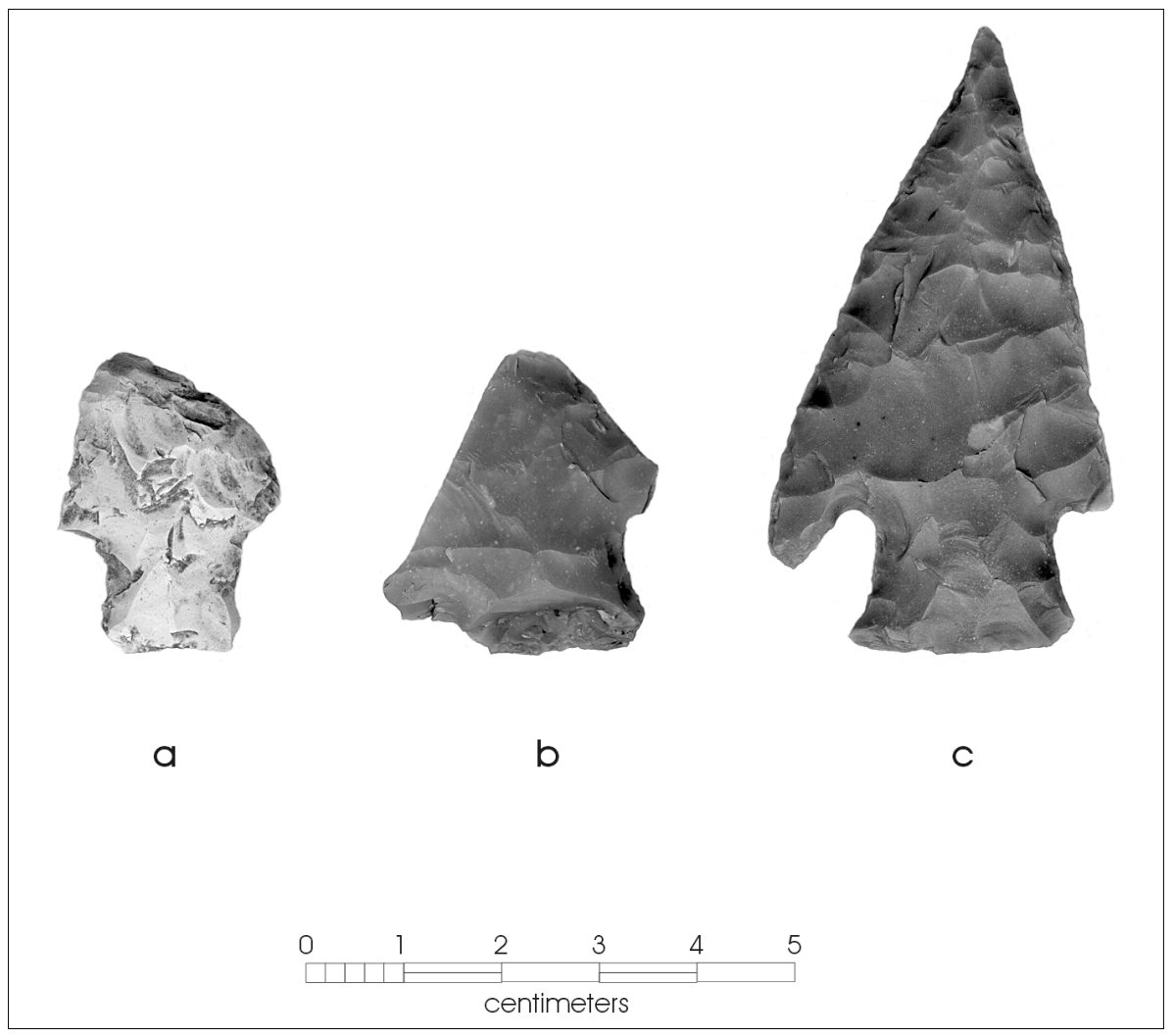

Figure E-12. Projectile points recovered from 41BR474: (a) UI \#1, surface; (b) Shovel Test 24, Level 1; (c) Area 1, backhoe trench, surface.

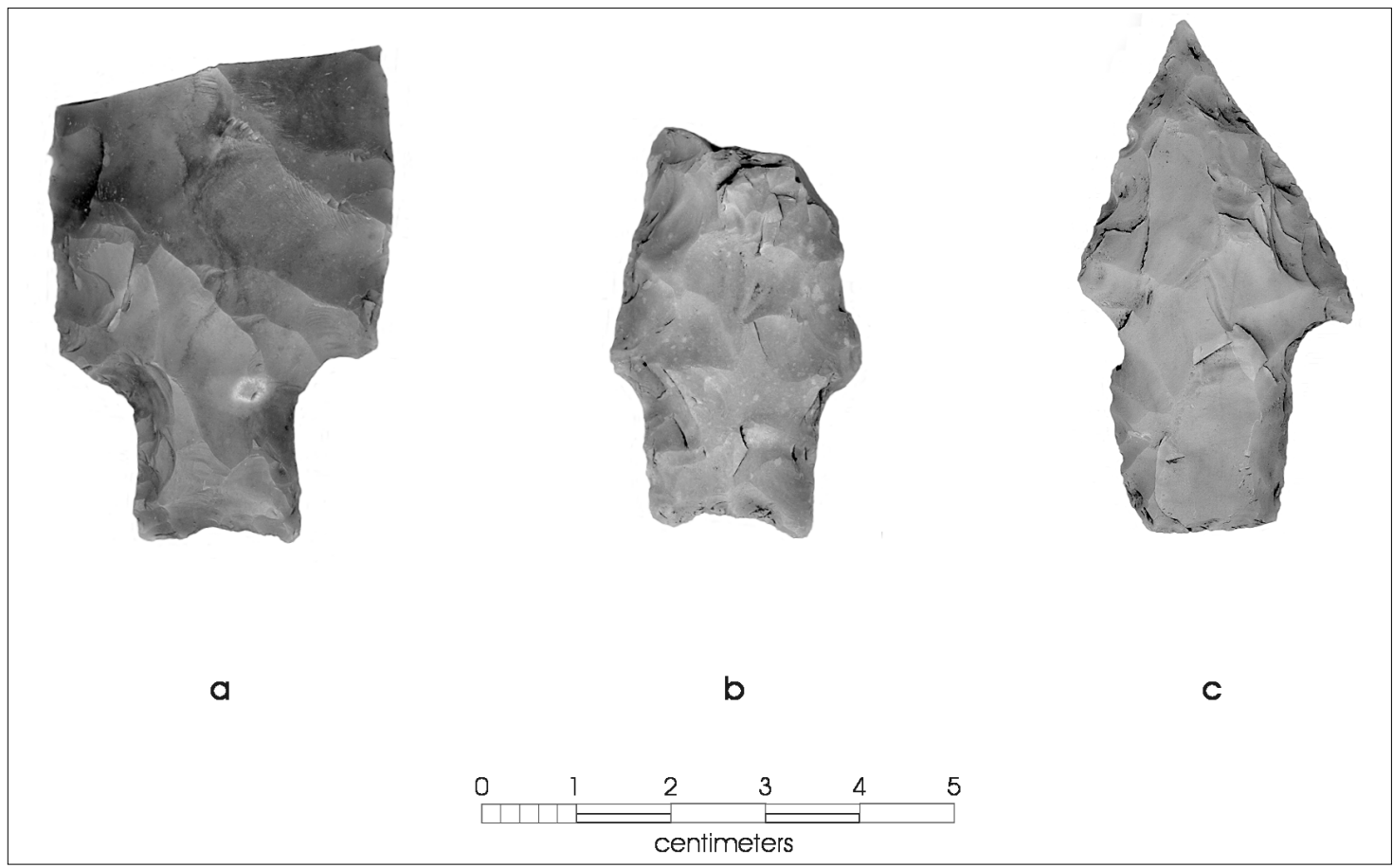

Figure E-13. Projectile points recovered from 41BR478: (a) Shovel Test 13, Level 2; (b) Unit 1, Level 4; (c) Unit 3, Level 4. 


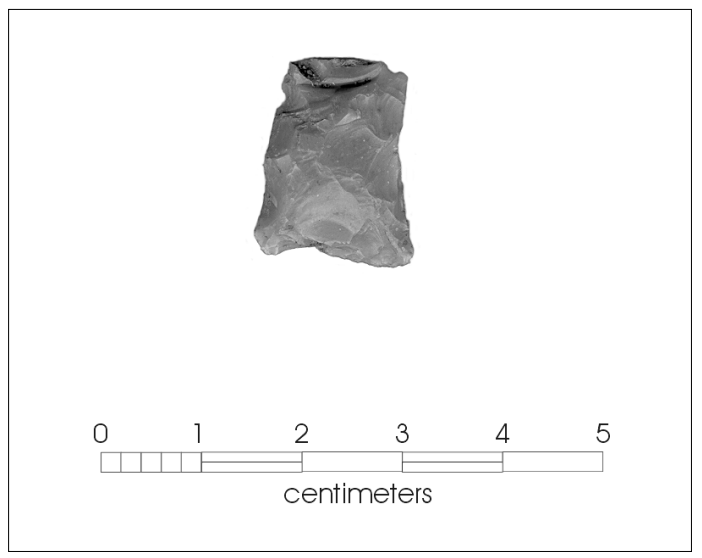

Figure E-14. Projectile point recovered from 41BR480; UI \#1, surface.

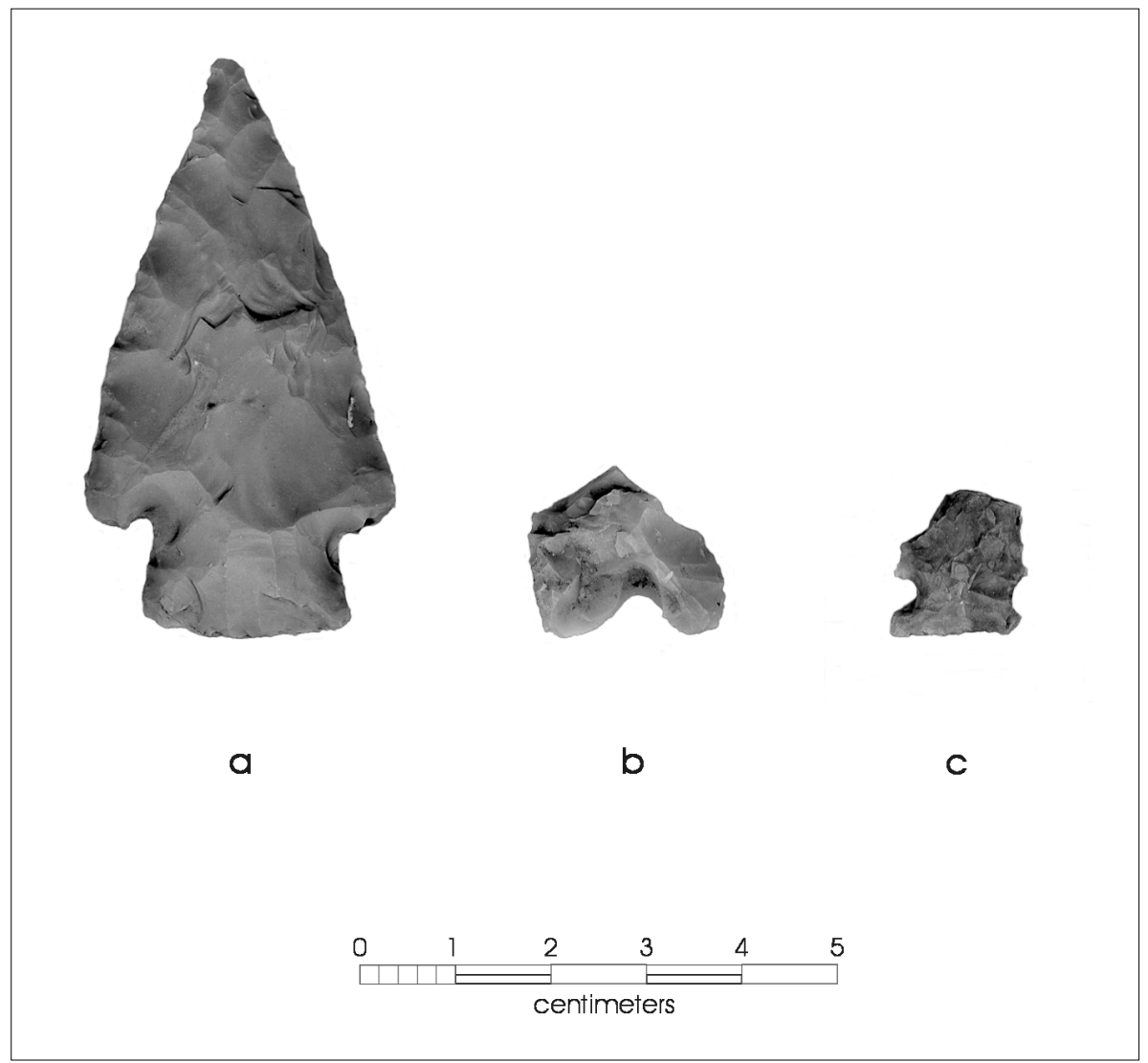

Figure E-15. Projectile points recovered from 41BR492: (a) Unit 1, Level 2; (b) UI \#1, surface; (c) Unit 4, Level 2. 
Appendix F Selected Other Tools 


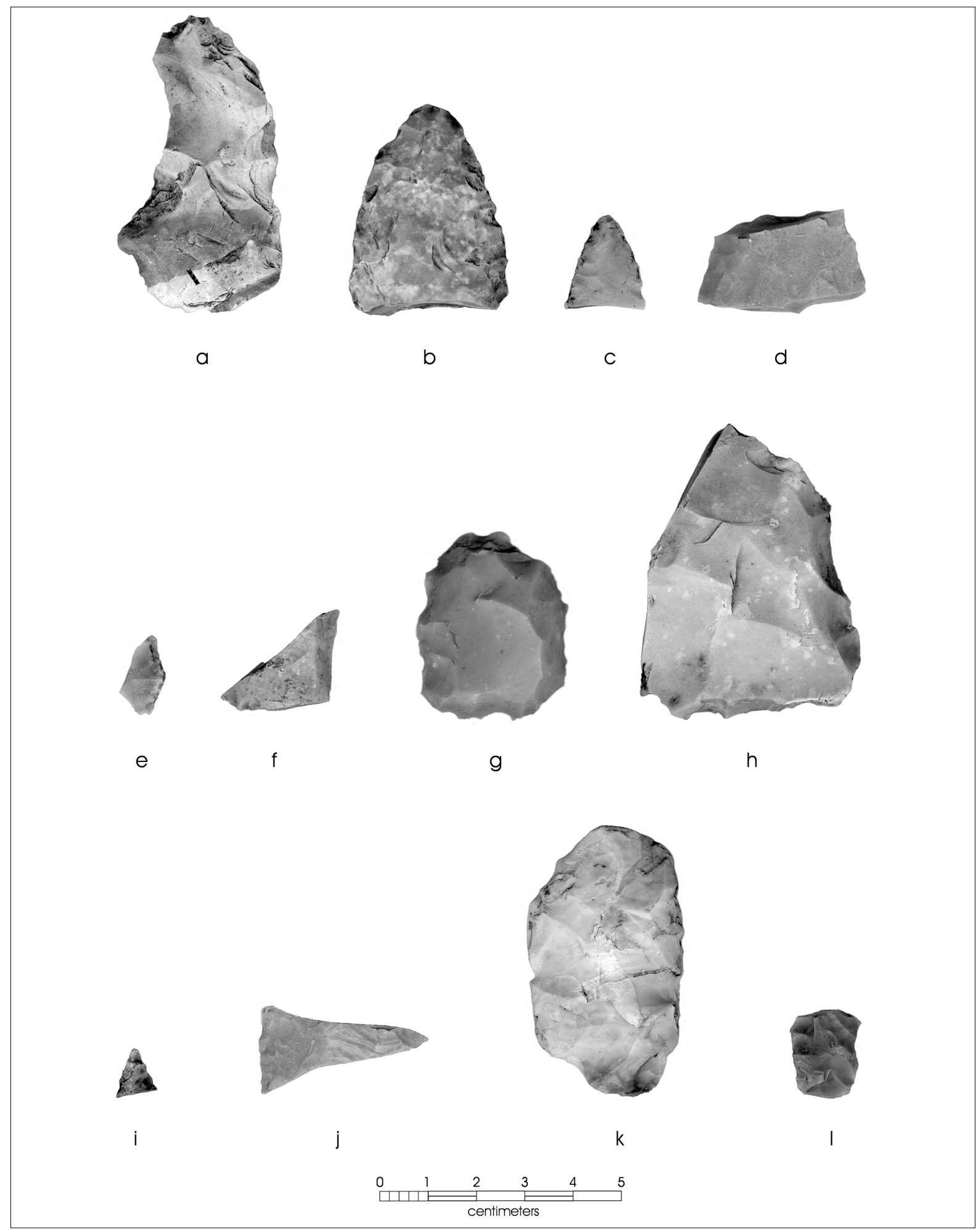

Figure F-1. Selected tools recovered from 41BR65: (a) Shovel Test 10, Level 3; (b) Shovel Test 11, Level 2; (c) Shovel Test 11, Level 2; (d) Shovel Test 12, Level 1; (e) Shovel Test 36, Level 2; (f) Shovel Test 37, Level 1; (g) Shovel 37, Level 2; (h) Unit 2, Level 3; (i) Unit 2, Level 3; (j) Unit 7, Level 7; (k) Unit 7, Level 7; (l) Unit 3, Level 2. 


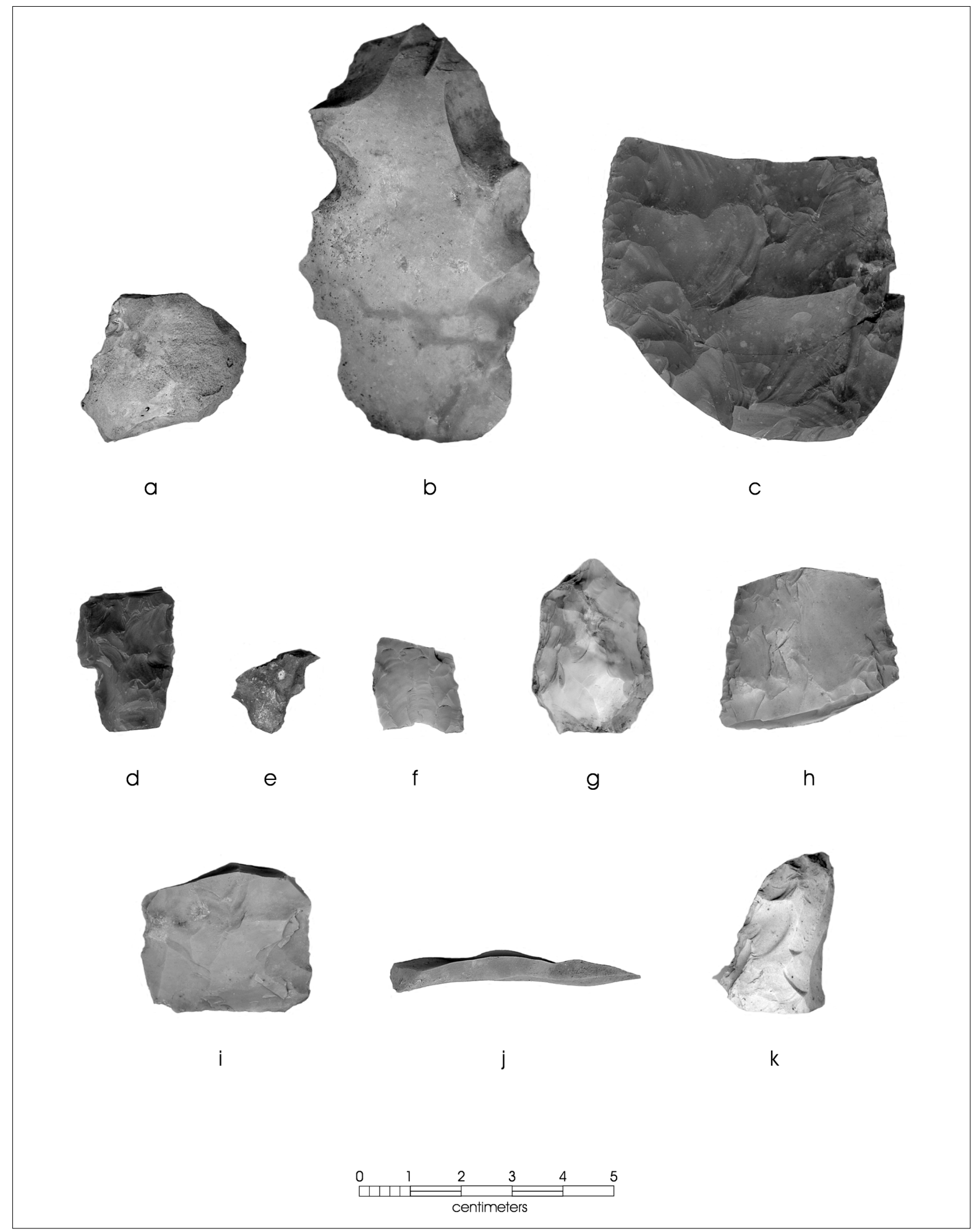

Figure F-2. Selected tools recovered from 41BR87: (a) Unit 1, Level 3; (b) Unit 8, Level 1; (c) Shovel Test 39, Level 1; (d) Shovel Test 30, Level 3; (e) Shovel Test 41, Level 2; (f) Unit 1, Level 3; (g) Unit 1, Level 3; (h) Unit 6, Level 2; (i) Unit 1, Level 1; (j) Unit 6, Level 3; (k) Unit 7, Level 3. 


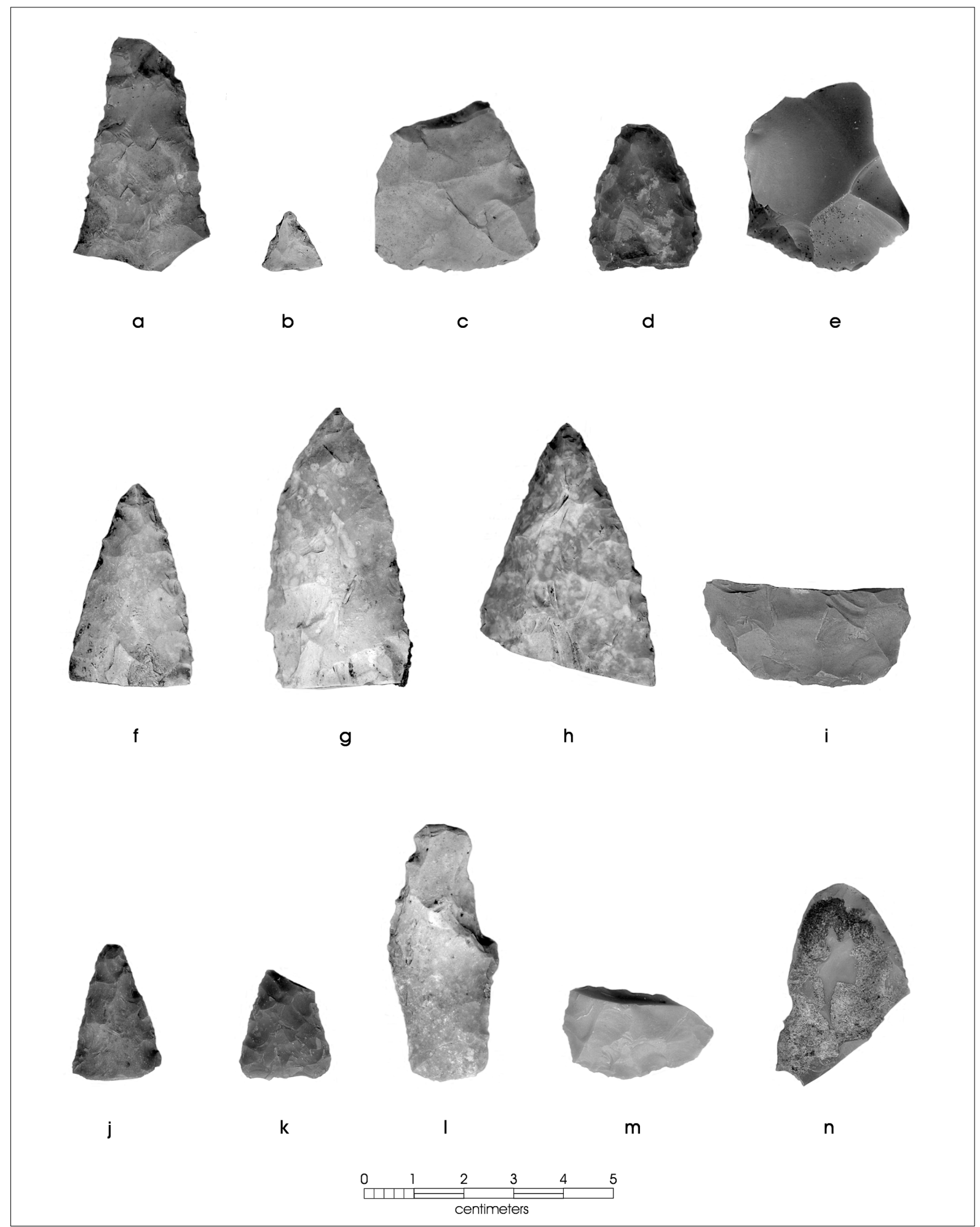

Figure F-3. Selected tools recovered from 41BR228: (a) Unit 2, Level 1; (b) Unit 3, Level 3; (c) Unit 1, Level 4; (d) Unit 8, Level 1; (e) Unit 8, Level 1; (f) Unit 9, Level 4; (g) Unit 8, Level 6; (h) Unit 9, Level 3; (i) Shovel Test 22, Level 2; (j) Shovel Test 74, Level 1; (k) Shovel Test 80, Level 1; (l) Shovel Test 83, Level 5; (m) Collection Area \#2, surface; ( $n$ ) Unit 3, Level 7. 


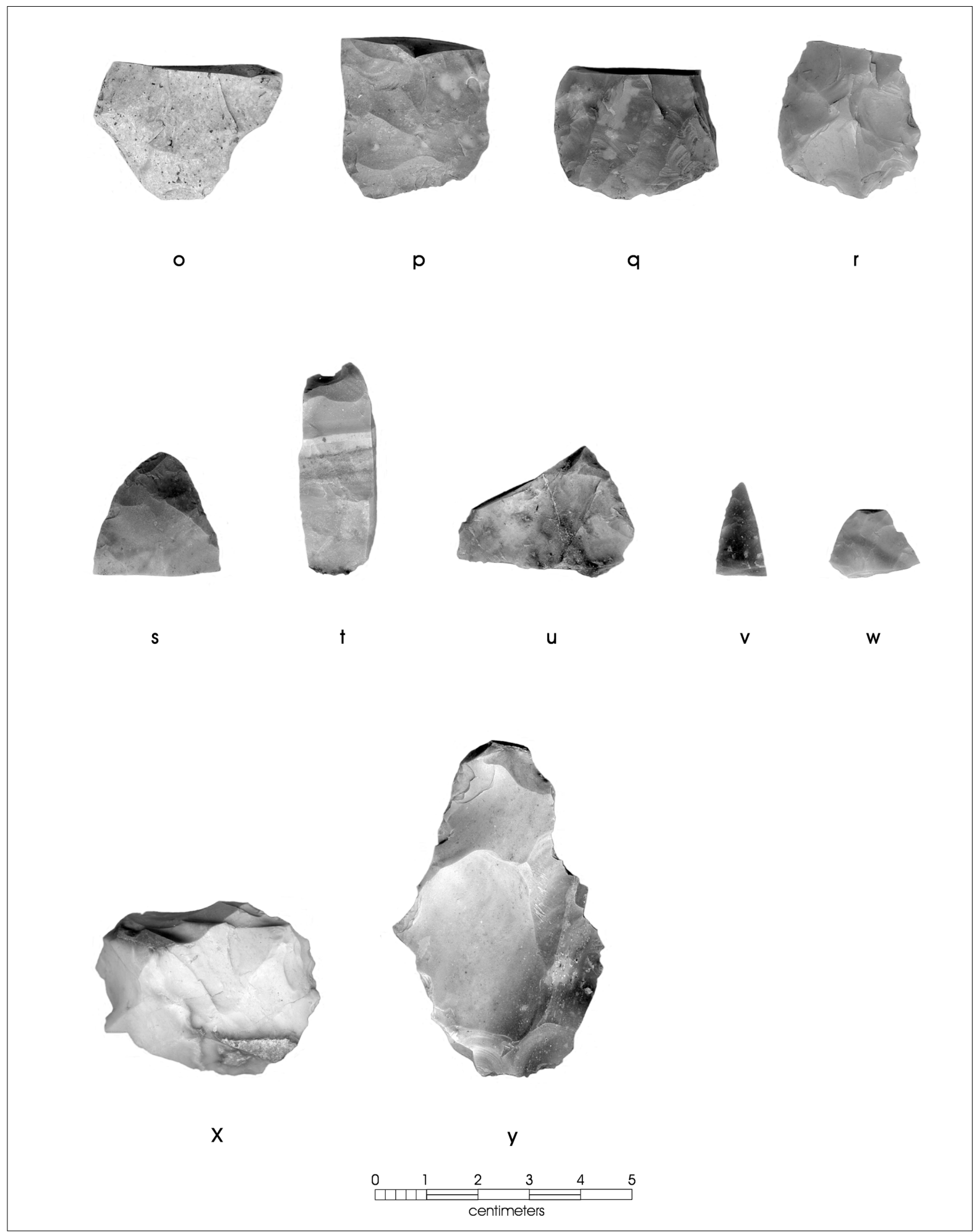

Figure F-3. continued... 41BR228: (o) Unit 4, Level 1; (p) Unit 4, Level 2; (q) Unit 4, Level 2; (r) Unit 4, Level 2; (s) Unit 5, Level 1; (t) Collection Area \#1, surface; (u) Collection Area \#1, surface; (v) Collection Area \#1, surface; (w) Collection Area \#1, surface; (x) Collection Area \#1, surface; (y) Collection Area \#3, surface. 


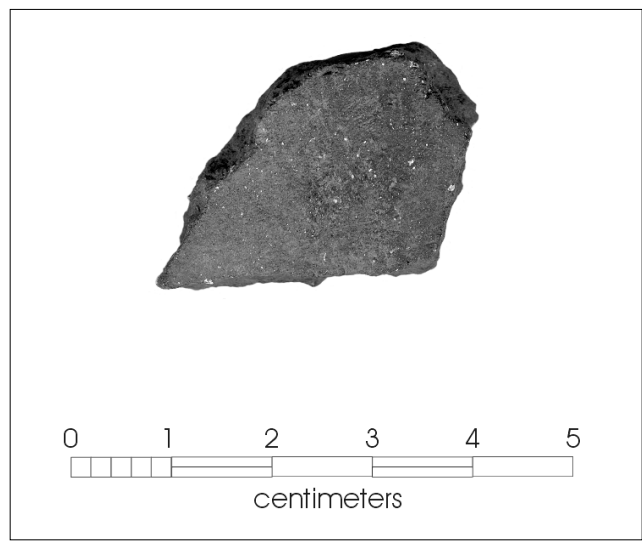

Figure F-4. Ceramic sherd recovered from 41BR228;

Unit 6, Level 2.

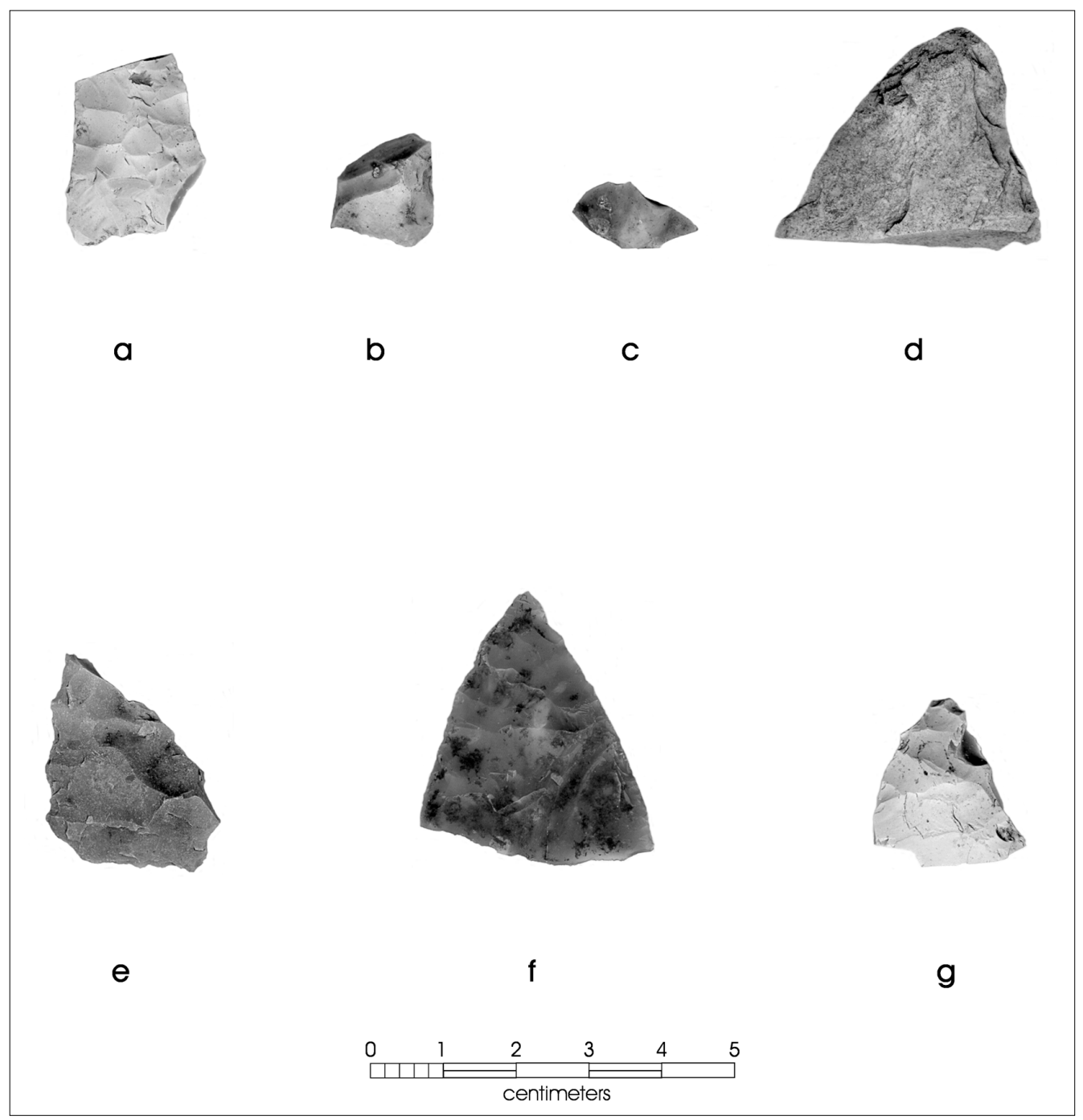

Figure F-5. Selected tools recovered from 41BR246: (a) Unit 3, Level 3; (b) Unit 3, Level 3; (c) Unit 3, Level 4; (d) Unit 3, Level 5; (e) Unit 1, Level 4; (f) Unit 1, Level 4; (g) Shovel Test 40, Level 4. 


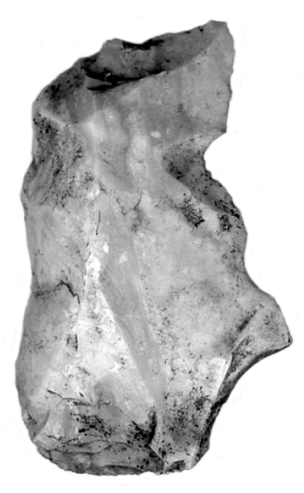

$\mathrm{h}$

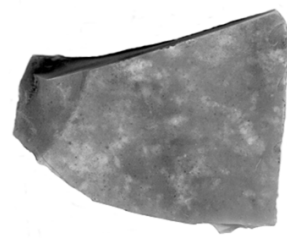

I

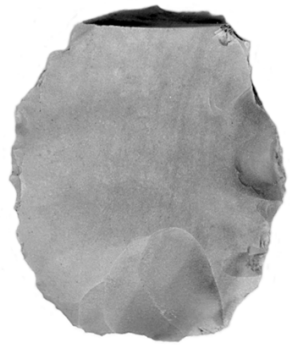

i

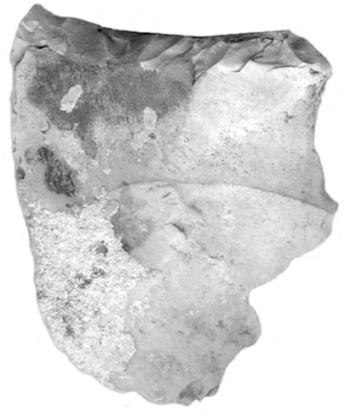

m
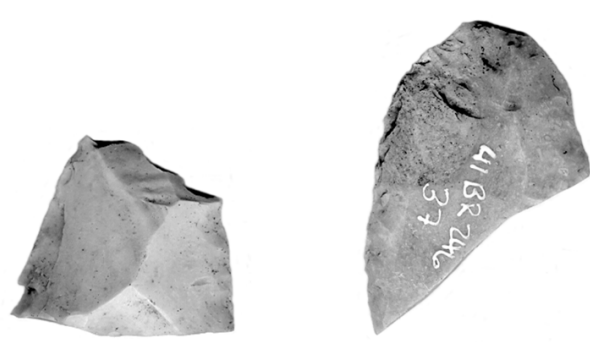

k

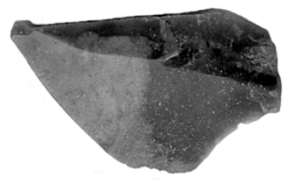

n

\begin{tabular}{|c|c|c|c|c|}
\hline 0 & 2 & 3 & 4 & \\
\hline$\square \square \mid F$ & $=$ & 5 & & \\
\hline
\end{tabular}

Figure F-5. continued...41BR246: (h) Unit 4, Level 4; (i) Unit 3, Level 4; (j) Unit 3, Level 4; (k) Unit 3, Level 4; (l) Unit 2, Level 18; (m) Shovel Test 19, Level 8; (n) Shovel Test 39, Level 3. 


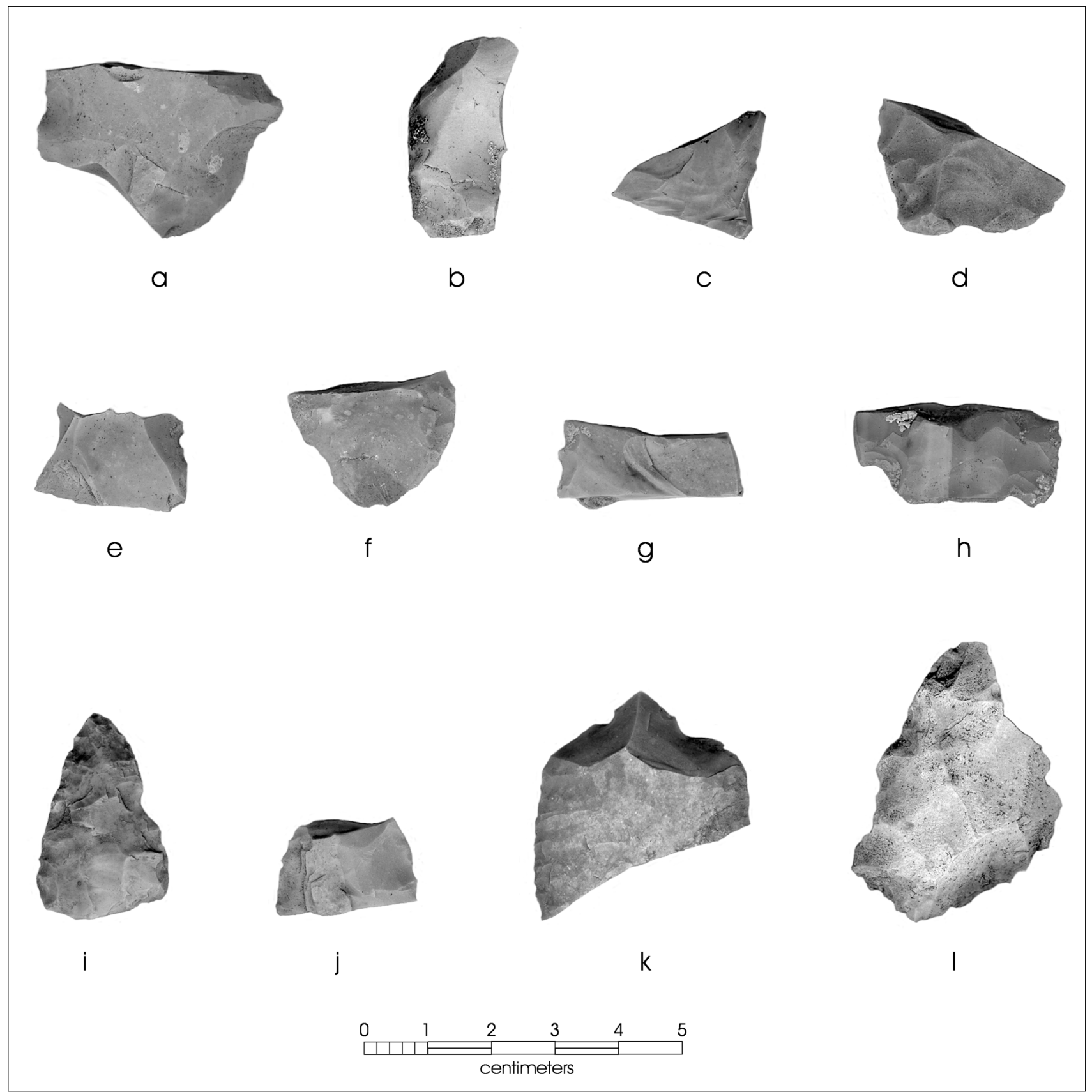

Figure F-6. Selected tolls recovered from 41BR250: (a) Collection Area \#1, surface; (b) Collection Area \#1, surface; (c) Collection Area \#1, surface; (d) Collection Area \#1, surface; (e) Collection Area \#1, surface; (f) Collection Area \#1, surface; (g) Collection Area \#1, surface; (h) Collection Area \#3, surface; (i) Collection Area \#3, surface; (j) Collection Area \#2, surface; (k) Collection Area \#2, surface; (l) Collection Area \#2, surface. 


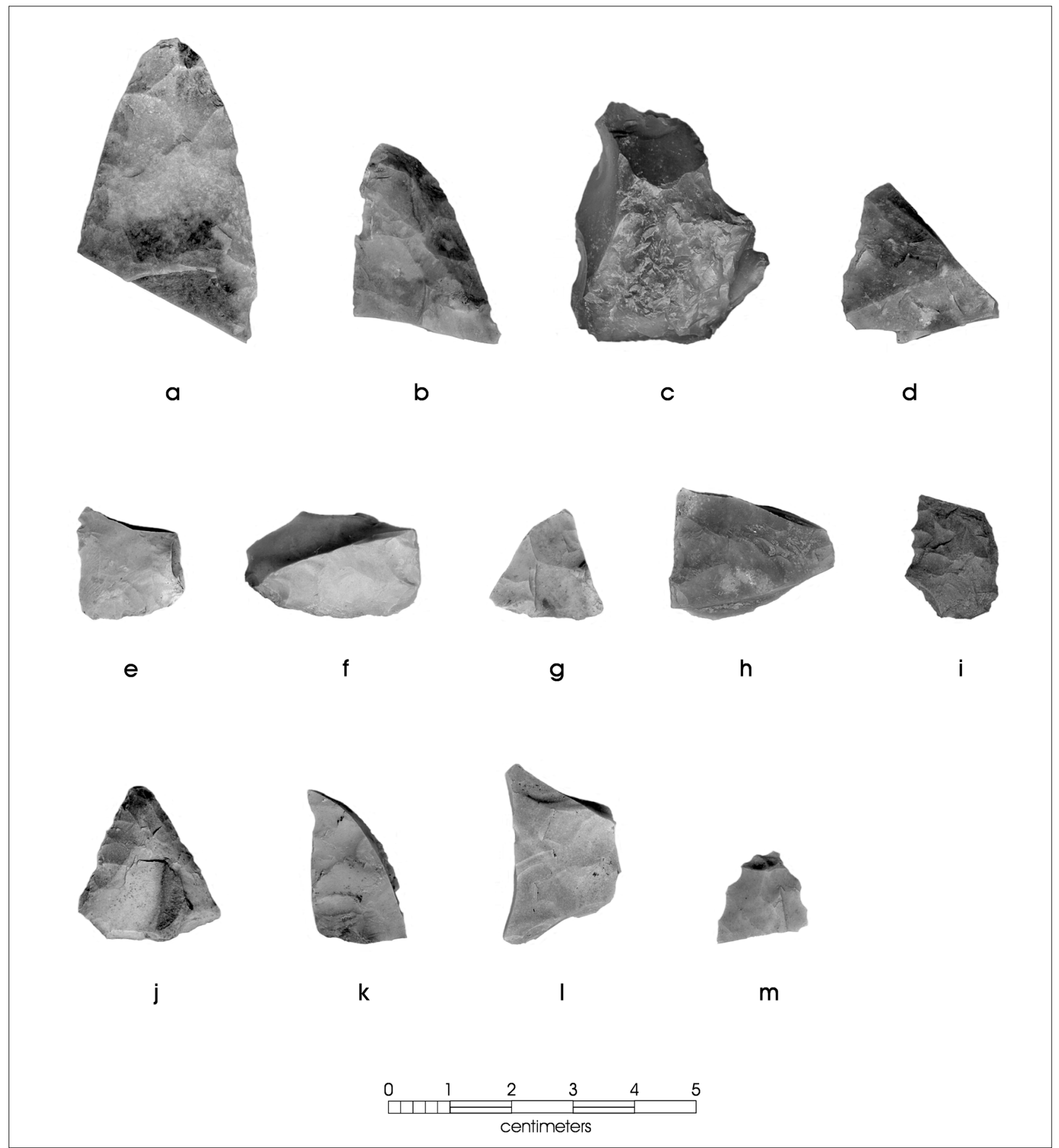

Figure F-7. Selected tools recovered from 41BR253: (a) UI \#3, surface; (b) Unit 8, Level 1; (c) Unit 8, Level 1; (d) Collection Area 32, surface; (e) Shovel Test 50, Level 2; (f) Collection Area \#1, surface; (g) Collection Area \#2, surface; (h) Unit 8, Level 1; (i) Collection Area \#3, surface; (j) Shovel Test 57, Level 1; (k) Shovel Test 58, Level 1; (l) Collection Area \#2, surface; (m) Unit 8, Level 1. 


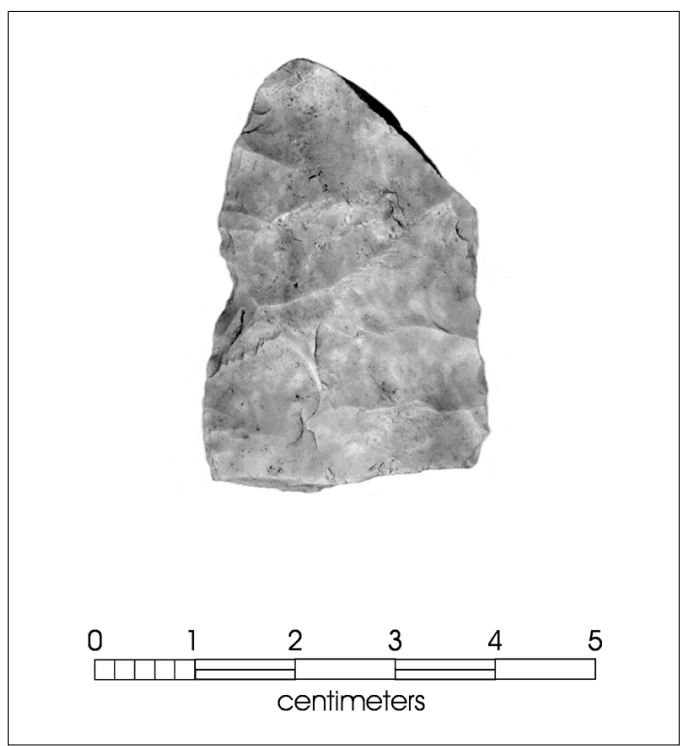

Figure F-8. Biface recovered from 41BR261;

Collection Area \#1, surface.

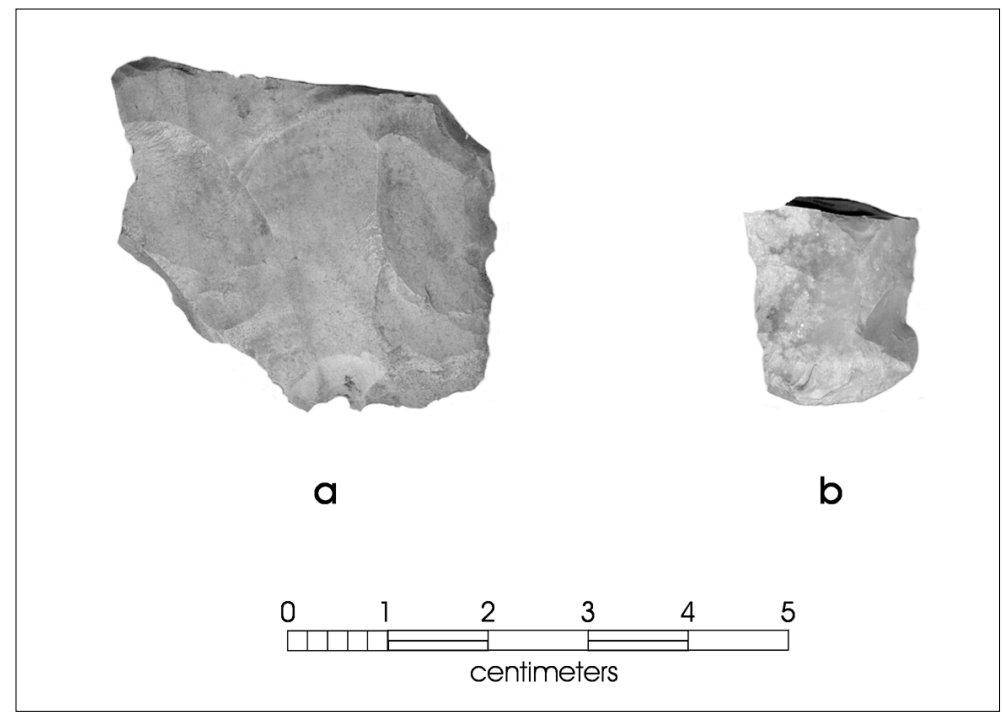

Figure F-9. Selected tools recovered from 41BR276: (a) Collection Area \#1, surface; (b) Shovel Test 22, Level 1. 


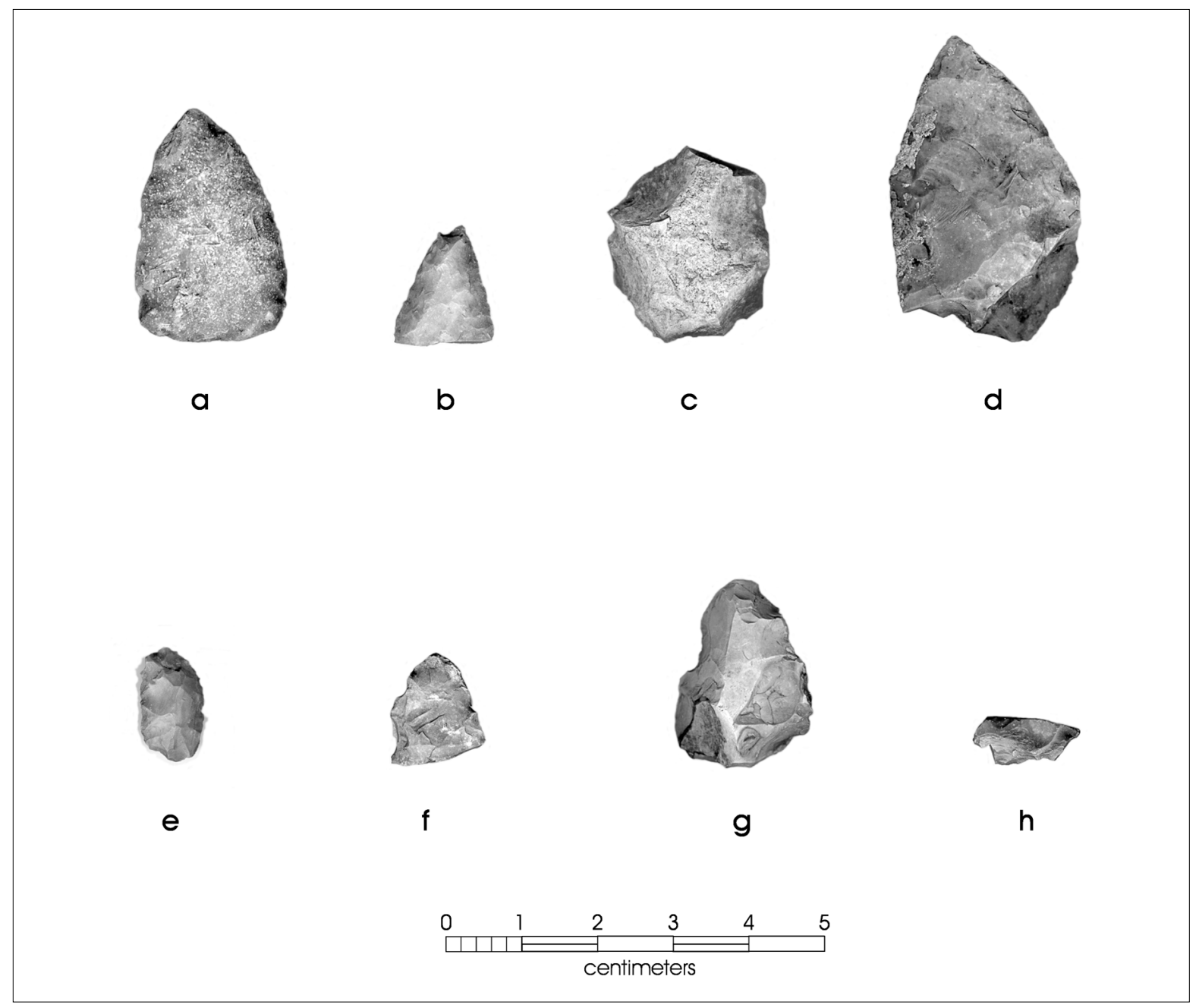

Figure F-10. Selected tools recovered from 41BR415: (a) UI \#4, surface; (b) UI \#1, surface; (c) UI\#2, surface; (d) Unit 2, Level 4; (e) Unit 6, Level 1; (f) Unit 7, Level 2; (g) Shovel Test 13, Level 1; (h) Shovel Test 16, Level 2. 


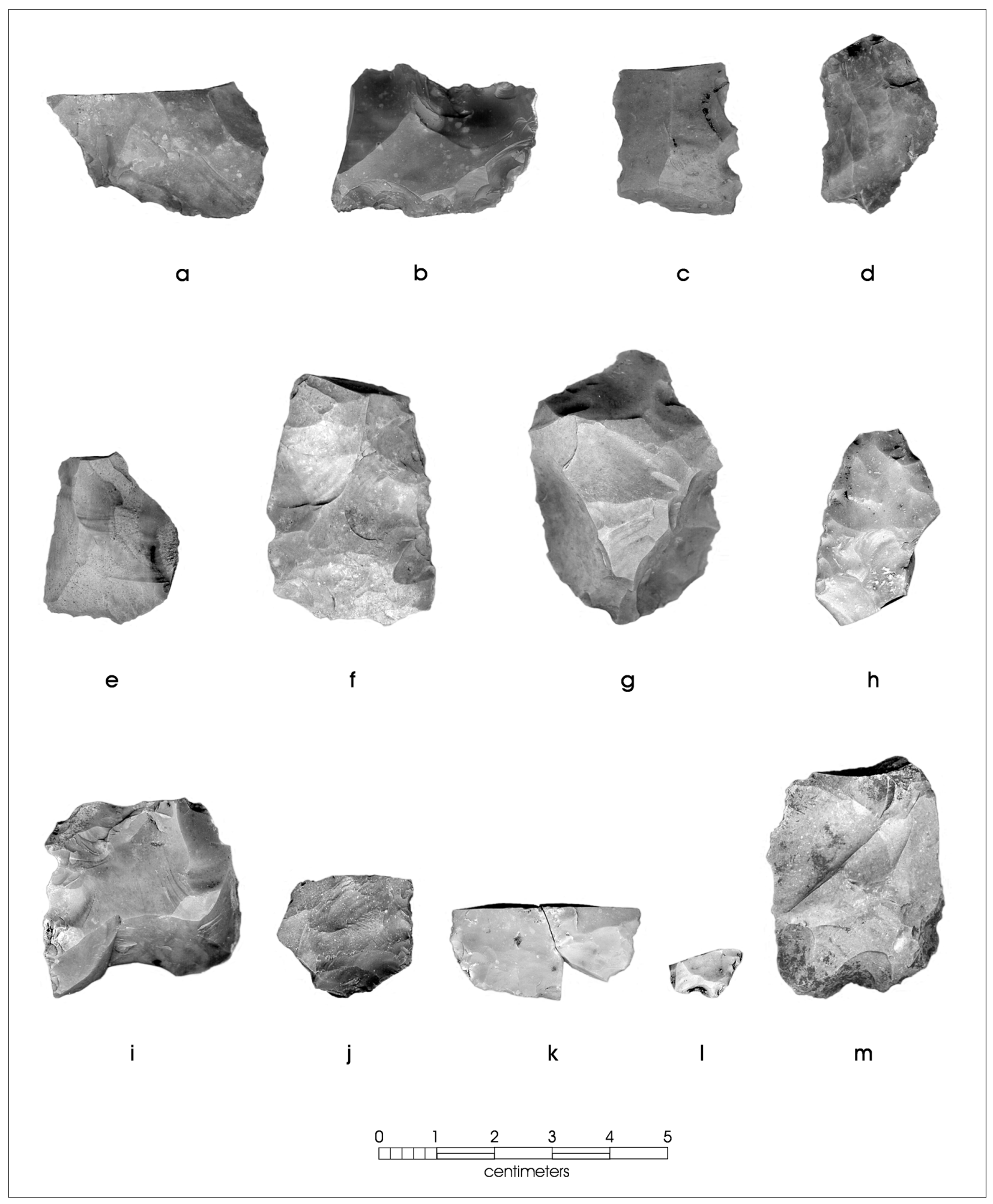

Figure F-11. Selected tools recovered from 41BR433: (a) Unit 4, Level 2; (b) Unit 4, Level 2; (c) Unit 2, Level 2; (d) Unit 2, Level 3; (e) Unit 2, Level 3; (f) Shovel Test 10, Level 4; (g) Shovel Test 28, Level 1; (h) Unit 2, Level 3; (i) Unit 2, Level 3; (j) Unit 5, Level 1; (k) Unit 5, Level 1; (l) Unit 3, Level 4; (m) Unit 4, Level 4. 


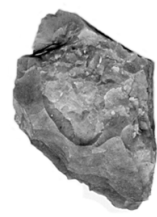

a

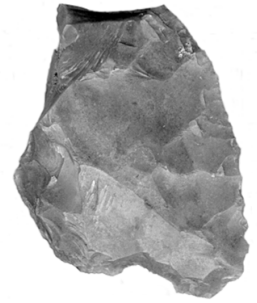

b

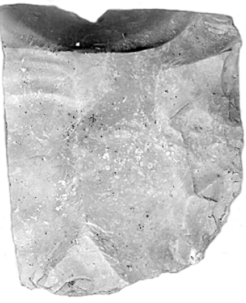

C

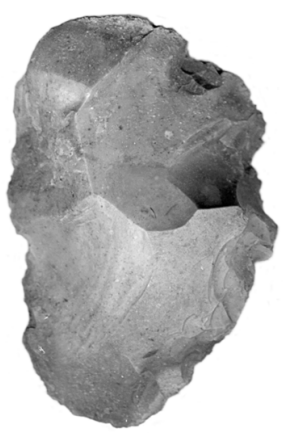

d

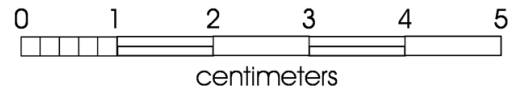

Figure F-12. Selected tools recovered from 41BR441: (a) Collection Area \#1, surface; (b) Collection Area \#1, surface; (c) Collection Area \#1, surface; (d) Collection Area \#1, surface.

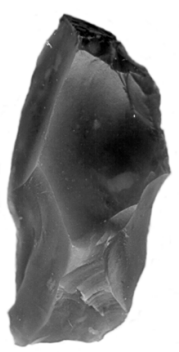

a

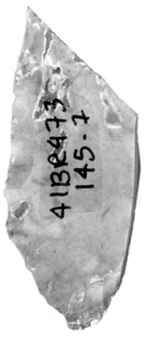

d

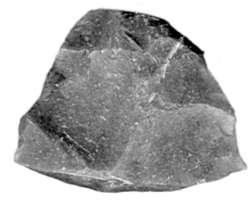

b

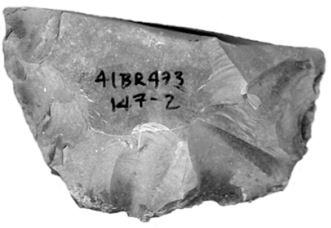

e

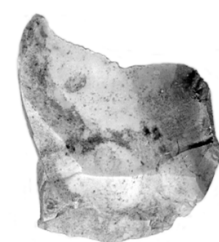

C

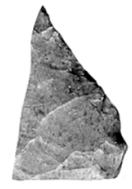

f

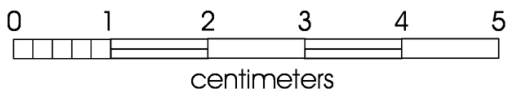

Figure F-13. Selected tools recovered from 41BR473: (a) Unit 1, Level 3; (b) Unit 1, Level 3; (c) Unit 1, Level 3; (d) Unit 1, Level 3; (e) Unit 1, Level 4; (f) Unit 1, Level 4. 


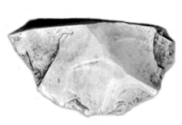

$a$

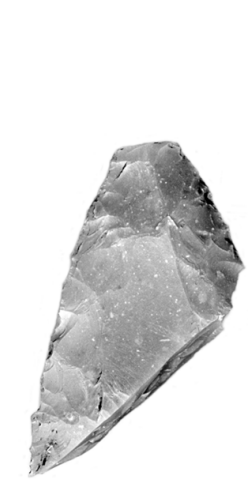

e

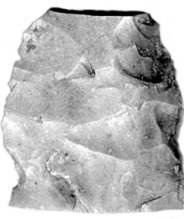

b

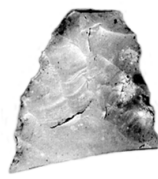

C

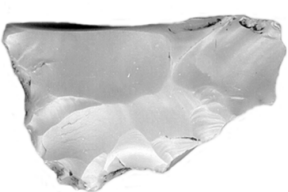

d

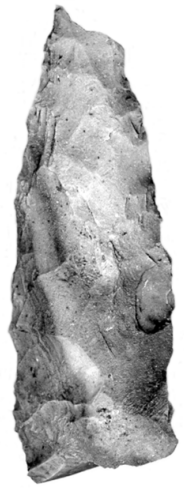

f

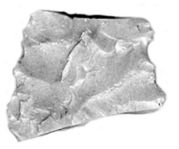

g

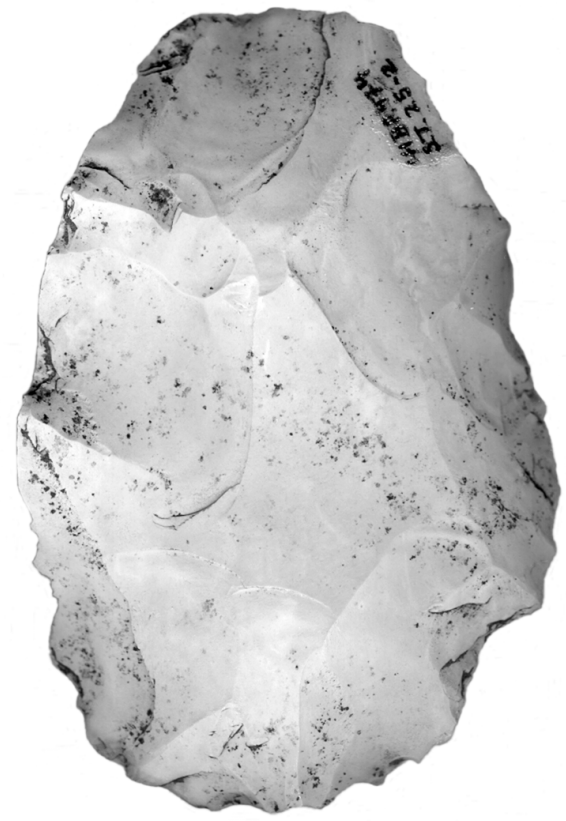

h

Figure F-14. Selected tools recovered from 41BR474: (a) Unit 6, Level 1; (b) Collection Area \#1, surface; (c) Shovel Test 13, Level 1; (d) Shovel Test 15, Level 1; (e) Shovel Test 24, Level 1; (f) Shovel Test 52, Level 1; (g) Shovel Test 67, Level 2; (h) Shovel Test 25, Level 2. 


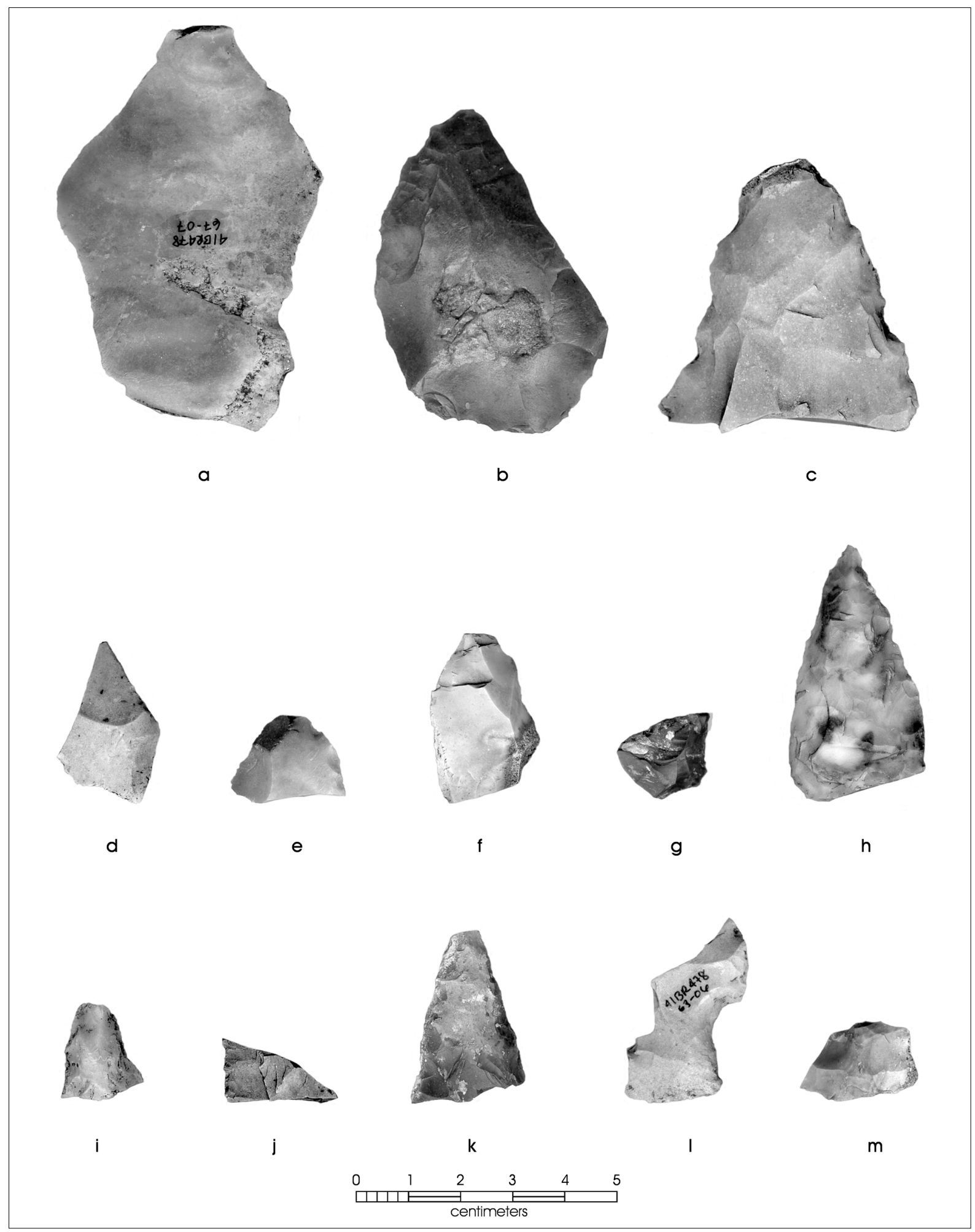

Figure F-15. Selected tools recovered from 41BR478: (a) Unit 2, Level 4; (b) Unit 1, Level 2; (c) Unit 1, Level 5; (d) Unit 1, Level 3; (e) Shovel Test 4, Level 8; (f) Unit 3, Level 3; (g) Unit 1, Level 8; (h) Unit 1, Level 3; (i) Unit 2, Level 3; (j) Unit 2, Level 2; (k) Unit 3, Level 8; (l) Unit 1, Level 3; (m) Shovel Test 11, Level 1. 


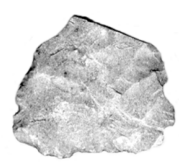

$a$

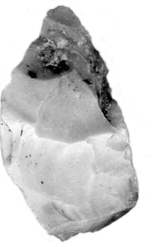

e

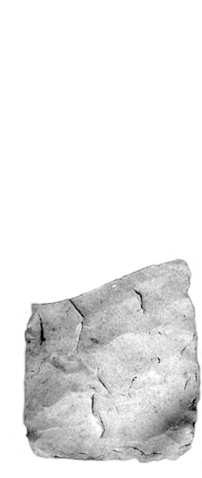

h

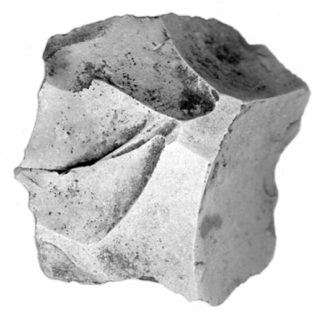

b

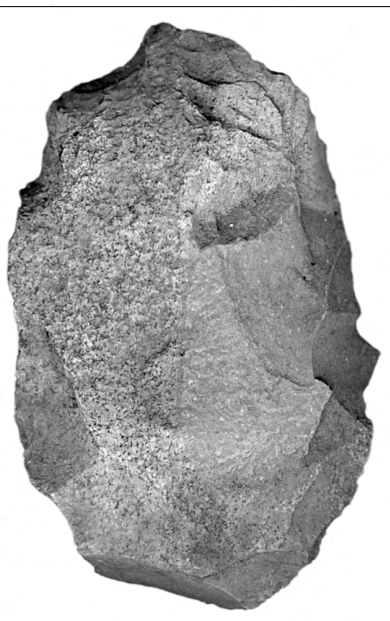

c

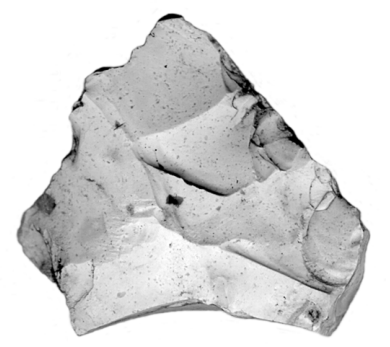

d

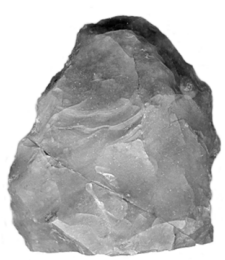

f

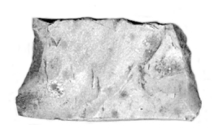

g

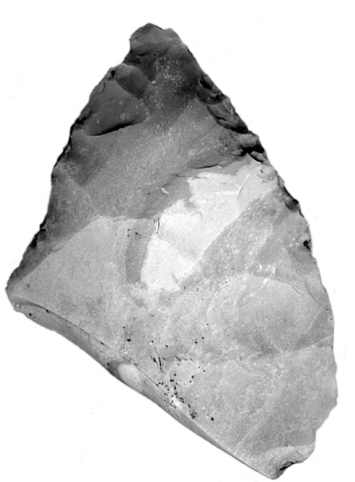

i

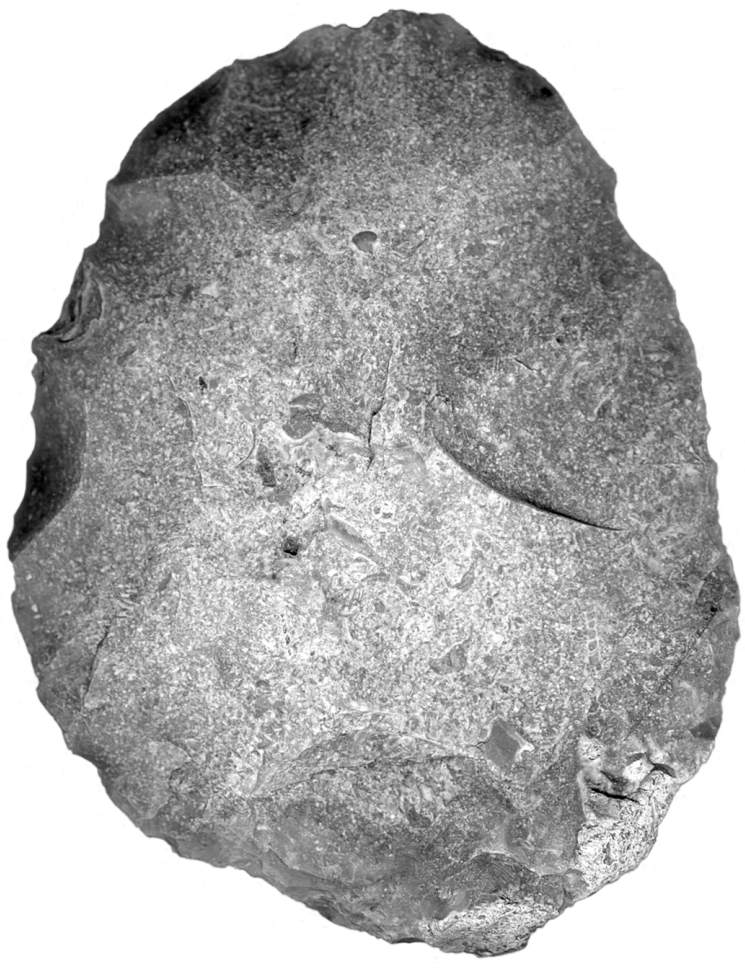

j

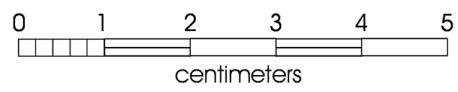

Figure F-16. Selected tools recovered from 41BR480: (a) Collection Area \#1, surface; (b) Collection Area \#1, surface; (c) Collection Area \#1, surface; (d) Collection Area \#2, surface; (e) Shovel Test 18, Level 1; (f) Shovel Test 26, Level 1; (g) Shovel Test 33, Level 1; (h) Shovel Test 60, Level 1; (i) Unit 2, Level 2; (j) Unit 5, Level 1. 


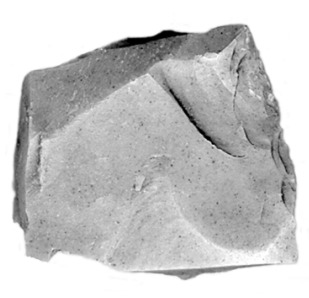

a

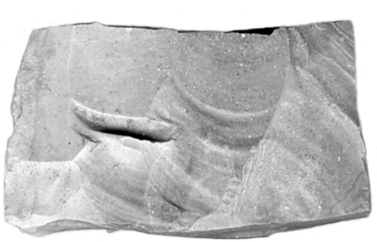

b

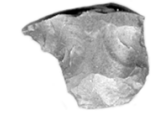

C

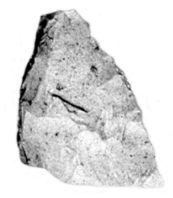

d

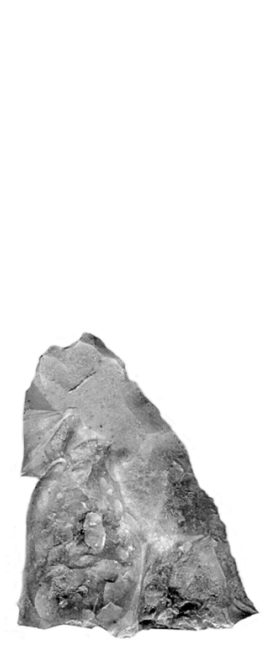

h

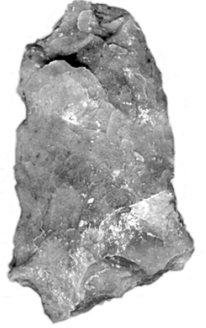

e

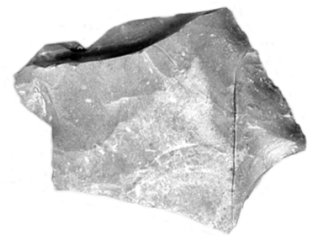

$f$

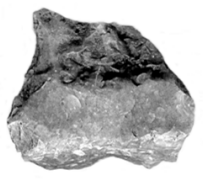

9

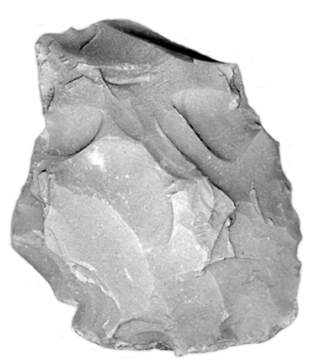

i

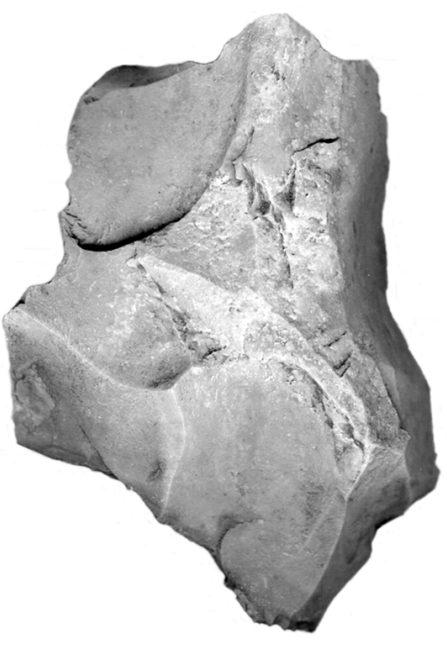

j

\begin{tabular}{|c|c|c|c|}
\hline $\begin{array}{ll}0 & 1 \\
\end{array}$ & 2 & 3 & 4 \\
\hline 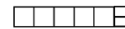 & $=$ & F & $\Rightarrow$ \\
\hline
\end{tabular}

Figure F-17. Selected tools recovered from 41BR492: (a) Unit 5, Level 2; (b) Unit 5, Level 2; (c) Unit 5, Level 2; (d) Unit 4, Level 2; (e) Unit 1, Level 11; (f) UI \#2, surface; (g) Unit 5, Level 4; (h) Shovel Test 19, Level 3; (i) Shovel Test 30, Level 1; (j) Unit 4, Level 4. 


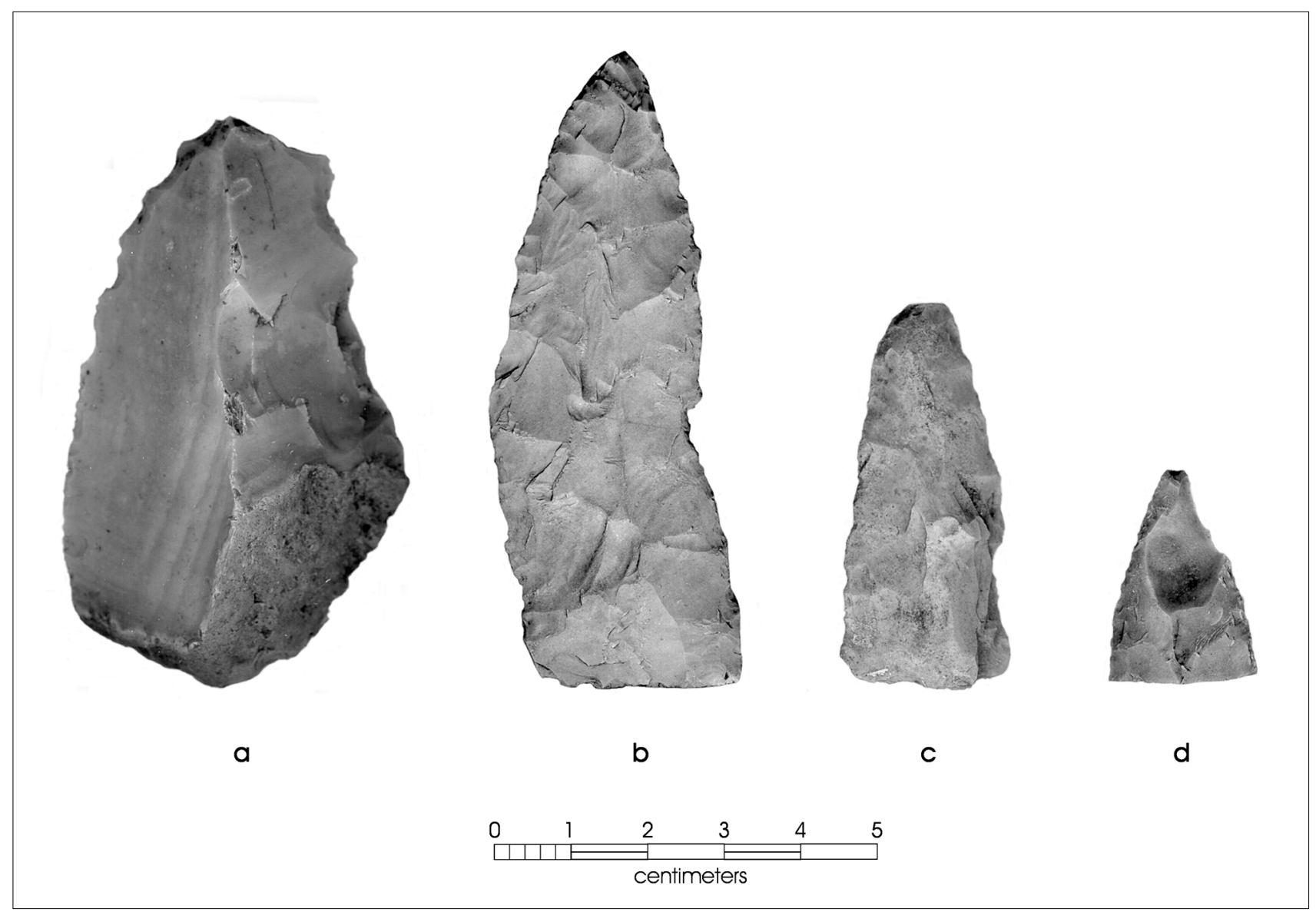

Figure F-18. Selected tools recovered from 41BR493: (a) Unit 1, Level 6; (b) Unit 3, Level 7; (c) Unit 2, Level 10; (d) Unit 2, Level 8. 
Appendix G

Geomorphology 


\title{
Appendix G: The Geology of Archaeological Sites on Camp Bowie
}

\author{
C. Britt Bousman and Linda Hodges
}

\section{Introduction}

This appendix provides an overview of the geological setting of selected sites on Camp Bowie, Brown County, Texas. Detailed descriptions of each profile are provided with each site discussion. This appendix should be used in conjunction with Chapter 6, the site descriptions, in volume 1 of this report. Figures of selected units described here can be found in that chapter.

Camp Bowie is in Brown County, only a few miles south of the city of Brownwood. Brown County is centrally located in the rolling plains of Texas. The Camp Bowie terrain consists of small floodplains, and small colluvial and alluvial fans below sandstone and limestone escarpments on the edges of mesas. The bedrock geological formations consist of Strawn Group, Ricker Station, Travis Peak Limestone, Undivided Quaternary, and Recent Alluvium (Barnes 1967). Floodplains, alluvial fans, and uplands are identified by Clower (1980) in Brown and Mills counties. Frio soils are found in the floodplains. The uplands have a variety of different soil series and associations. In the uplands are Winters, Abilene, Nukrum, Desan, Leeray, Sagerton, Bonti, Throck, Callahan, Pedernales, Double, and Real soils. The soil associations, which formed on alluvial and colluvial fans, include Bonti-Callahan, Callahan-Throck, BontiThrock, and Double-Real.

\section{Geology}

Strawn Group Undivided, dating to the Pennsylvanian, is the oldest formation at Camp Bowie. The Strawn Group consists of ss1-ss37, Capps Limestone (Ipc), Ricker Station Limestone (Iprs), and pre-Brazos River Undivided (Ippbr). Included in the Strawn Group are sandstones, shales, mudstones, conglomerates, siltstones, and limestones. The shales and mudstones are silty greenish-gray to red with common mud cracks. The limestone beds are generally continuous, and more abundant near the top while the sandstones form thin discontinuous sheets and small channel fills with fewer beds near the top.

Two formations specifically found at Camp Bowie are the Strawn Group Undivided (ss31-ss32) and the Ricker Station Limestone. In the Strawn Group Undivided, the ss31 and ss32 are most abundant near the middle of the formation. Ss 31 and ss 32 are mostly sandstone with some mudstones and conglomerates. The thin to massive beds of brown to red sandstone form the rocky and heavily wooded hills with east and southeast facing scarps. Each unit is up to 100 feet or more thick.

Ricker Station Limestone is locally arenaceous with subrounded chert in a thin discontinuous layer. This grayishbrown limestone is commonly eroded by sandstone channel fills to the east and southeast of Brownwood. The thickness of the Ricker Station Limestone is up to four feet.

The next youngest formation is the Cretaceous Travis Peak Limestone. The Travis Peak Formation consists of conglomerates, sandstones, and limestones. Conglomerates, cemented by red to white calcite, are sandy and composed of pebbles, cobbles, and boulders from Paleozoic limestone, dolomite, chert, and sandstone. The red to white, silty, conglomerate sandstone is composed of mostly quartz or fossil fragments. Thickness of the Travis Peak Formation is up to 175 feet, but varies because of the irregularity of the surfaces on which it was deposited and variations in the contact with the overlying Glen Rose Formation.

Stratified above the Cretaceous formations are undivided Quaternary surface deposits. These deposits consist of terraces, lag gravels, residual soils, colluvium, local channel fills, gravels, caliche, sands, and clays. Gravels consist of Cretaceous and Paleozoic limestone, chert, and quartz. The gravels found in the surface deposits commonly are cemented by caliche. The surface deposits can be over 50 feet thick.

The most recent geological formation is alluvium from streams or riverbeds. The alluvial deposits include low terrace deposits and floodplains. Gravel, sand, silt, clay, and organic matter make up the bulk of these alluvial deposits. The thickness of the alluvium is up to 35 feet.

\section{Soils}

Frio soils formed in calcareous alluvium and are located on frequently flooded bottomlands. At Camp Bowie, Frio soils consist of deep, loamy soils located along Lewis Creek. A 
typical pedon consists of an Ap horizon of brown (10YR4/3) silty clay loam with weak granular structure at a depth of 0-18 cm. Below, the A1 horizon, between $18-55 \mathrm{~cm}$, is dark brown (10YR3/3) silty clay with blocky structure. The A2 horizon is brown (10YR4/3) silty clay with very fine subangular blocky structure and extends between $55-85 \mathrm{~cm}$. Finally, the $\mathrm{C}$ horizon is typically a yellowish-brown (10YR5/4) silty clay with films and threads of calcium carbonate between $85-180 \mathrm{~cm}$.

The Winters soil series are deep upland soils formed in thick beds of sandy and loamy sediment. A typical pedon consists of a $15 \mathrm{~cm}$ thick Ap horizon of red-brown (5YR5/4) fine sandy loam with weak, fine blocky structure. Bt1, Bt2 and Bt3 horizons are reddish-brown (2.5YR4/4) to yellowishred (5YR5/6) clay to clay loams with moderate, medium blocky to weak, fine blocky structure at a depth of 15-120 $\mathrm{cm}$. The $\mathrm{Bt} 4$ horizon is a reddish-yellow (5YR6/6) clay loam with weak, fine blocky structure between $120-160 \mathrm{~cm}$. A C horizon consists of a yellowish-red (5YR5/8) clay loam with friable structure from 160-200 cm.

The Abilene series is deep and located on broad plains and shallow valleys of the uplands. This soil formed in ancient alluvium. A typical pedon is an A1 horizon of very dark gray brown $(10 \mathrm{YR} 3 / 2)$ clay loam with moderate, fine subangular blocky structure at a depth of $0-25 \mathrm{~cm}$. The Bt1 and Bt2 horizons are very dark gray brown (10YR3/2) to brown $(7.5 \mathrm{YR} 4 / 2)$ clay with moderate, fine blocky structure at a depth of $25-60 \mathrm{~cm}$. The $\mathrm{Bt} 3$ and $\mathrm{Bt} 4$ range from $7.5 \mathrm{YR}$ $5 / 2$ to 10 YR $5 / 3$ (brown) clay with a moderate, fine blocky structure at a depth of $60-105 \mathrm{~cm}$. The $\mathrm{C} 1$ horizon is reddishyellow (7.5YR6/6) sandy clay with firm structure at a depth of $105-133 \mathrm{~cm}$. A C2 horizon is a very pale brown (10YR $7 / 4$ ) clay with firm structure and 20 percent soft bodies of calcium carbonate between $133-160 \mathrm{~cm}$.

The Nukrum series are deep upland soils formed in calcareous, clayey outwash sediments. A typical pedon is an Ap horizon of dark grayish-brown (10YR4/2) silty clay with a weak, fine subangular blocky structure at a depth of $0-15 \mathrm{~cm}$. The A horizon is dark grayish-brown (10YR4/2) silty clay with a moderate, fine and medium subangular blocky structure at a depth of $15-60 \mathrm{~cm}$. The B horizon is a grayish-brown (10YR5/2) silty clay with a moderate, medium subangular blocky structure at a depth of 60-140 $\mathrm{cm}$. A C horizon is a brown (10YR5/3) silty clay loam with hard and firm concretion and soft bodies of calcium carbonate between 140-180 cm.
The Desan series are deep upland soils formed in thick beds of sandy and loamy material. A typical pedon has a brown $(10$ YR5/3) loamy fine sand with a single grain, loose, and very friable Ap horizon at a depth of $0-20 \mathrm{~cm}$. The A horizon is a reddish-yellow (7.5YR6/6) loamy fine sand with single grain, loose, and very friable structure at a depth of 20-135 $\mathrm{cm}$. The Bt1 and Bt2 horizons are yellowish-red (5YR5/6) sandy clay loam with moderate, course prismatic structure at a depth of $135-200 \mathrm{~cm}$.

The Leeray series are deep upland soils formed in thick beds of brownish, calcareous clay. The typical pedon is an Ap horizon of dark grayish-brown (10YR4/2) clay with moderate, fine granular structure at a depth of $0-15 \mathrm{~cm}$. The A1 horizon is dark grayish-brown $(2.5 \mathrm{Y} 4 / 2)$ clay with moderate, fine angular blocky structure at a depth of 15-65 $\mathrm{cm}$. The A2 horizon is brown (10YR4/3) clay with weak, fine blocky structure between $65-120 \mathrm{~cm}$. The $\mathrm{C}$ horizon is a brownish-yellow (10YR6/6) clay with very firm structure at a depth of $120-150 \mathrm{~cm}$.

The Sagerton series are deep loamy upland soils formed in calcareous clayey sediments. A typical pedon is an Ap horizon of dark brown (7.5YR4/2) clay loam with moderate, very fine subangular blocky and granular structure at a depth of $0-15 \mathrm{~cm}$. The Bt1 horizon is a reddish-brown $(5 \mathrm{YR} 4 / 3)$ clay loam with moderate, medium subangular structure at a depth of $15-30 \mathrm{~cm}$. The Bt2 horizon is a reddish-brown (5YR4/4) clay with weak, moderate pristine structure at a depth of $30-68 \mathrm{~cm}$. The Bt3 horizon is brown (7.5YR5/4) clay with moderate fine subangular blocky structure at a depth of $68-98 \mathrm{~cm}$. The Bt4 horizon is a reddish-yellow (7.5YR6/6) clay loam with weak, very fine subangular blocky structure at a depth of $98-200 \mathrm{~cm}$.

The Bonti soil is moderately deep and is derived from weathered sandstone. The typical pedon consists of an A horizon of brown (7.5YR5/4) with stony, fine sandy loam with weak, very fine granular structure at a depth of $0-28$ $\mathrm{cm}$. Bt1 and Bt2 horizons are reddish-brown (5YR4/4) to reddish-yellow (7.5YR6/6) with a clay loam and moderate, course prismatic structure at a depth of $28-95 \mathrm{~cm}$. The final $\mathrm{R}$ horizon is strong brown, red, or yellowish sandstone.

The Throck series are deep upland soils formed in calcareous shaly clay and clayey marl. A typical pedon is an A horizon of grayish-brown (10YR5/2) that has a stony clay loam of moderate, fine blocky structure between $0-20 \mathrm{~cm}$. The B horizon is a yellowish-brown (10YR6/4) with fine blocky 
structure at a depth of $20-80 \mathrm{~cm}$. The $\mathrm{C}$ horizon is light yellowish-brown (2.5YR6/4) shaly clay with 40 percent being of platy rock structure between $80-150 \mathrm{~cm}$.

The Callahan series are deep upland soils formed in material weathered from interbedded shaly clay. A typical pedon is an Ap horizon of brown (7.5YR4/4) loam with weak, fine granular structure at a depth of $0-10 \mathrm{~cm}$. The Bt 1 horizon is reddish-brown (5YR4/4) clay with moderate, medium and fine blocky structure at a depth of $10-48 \mathrm{~cm}$. The $\mathrm{Bt} 2$ horizon is brown (7.5YR4/4) clay with moderate, fine blocky structure at a depth of $48-95 \mathrm{~cm}$. The $\mathrm{C}$ horizon is light olive brown (2.5Y5/4) shaly clay with concretions and soft bodies of calcium carbonate between $95-163 \mathrm{~cm}$.

The Pedernales series are deep upland soils formed in thick beds of calcareous clayey and loamy material. A typical pedon is an A horizon of brown (10YR5/3) fine sandy loam with weak, fine-grained structure between $0-35 \mathrm{~cm}$. The $\mathrm{Bt} 1$ and Bt2 horizons are reddish-brown (5YR5/4) made up of a clay or sandy clay, weak to moderate medium blocky structure at a depth of $35-93 \mathrm{~cm}$. The $\mathrm{C}$ horizon is a reddishyellow sandy clay loam, which included soft bodies of calcium carbonate between $93-150 \mathrm{~cm}$.

The Double series are deep loamy upland soils formed in weakly consolidated calcareous sandstone. A typical pedon is an A horizon of brown (10YR5/2) cobble loam and a very fine, subangular blocky structure at a depth of $0-15$ $\mathrm{cm}$. The B1 and B2 horizons are light brown (7.5YR6/4) to pink (5YR7/4) made up of loam and silty loam. The structure is weak to moderate, very fine subangular blocky structure between $15-90 \mathrm{~cm}$. The $\mathrm{C} 1$ and $\mathrm{C} 2$ horizons consist of a stratified reddish-yellow and pink weakly cemented finegrained calcareous sandstone between $90-120 \mathrm{~cm}$. The $\mathrm{C} 3$ horizon is a light reddish-brown (5YR6/4) loam and clay loam with a friable structure at a depth of $120-150 \mathrm{~cm}$.

Real soils are shallow and formed in material weathered from limestone. The typical pedon is an A horizon of dark gray brown (10YR4/2) to very dark gray brown (10YR3/2) clay loam of moderate, fine subangular blocky structure at a depth of $0-28 \mathrm{~cm}$. The $\mathrm{R}$ horizon consists of a pale yellow (5Y7/3) weakly cemented limestone between $28-60 \mathrm{~cm}$.

\section{BR65}

Two profiles were described from 41BR65. Profile 19 was taken from Unit 6 and Profile 20 was observed from Unit 5.
Unit 5 was placed off the single midden, while Unit 6 was placed in the midden's torus.

Seven zones were described in Profile 19 (Table G-1). The uppermost zone is an $\mathrm{O}$ horizon with modern plant matter in the upper $1 \mathrm{~cm}$. In Zone 2, between 1-30 cm, is a black ashy silt loam with abundant burned sandstone cobbles and tabular fragments (A1 horizon). Worm casts are also very common. Between $30 \mathrm{~cm}$ and $35-45 \mathrm{~cm}$ in Zone 3 is a dark gray silt loam A2 horizon that has less ash, but in Zone 4 (A3 horizon) the dark gray silt loam contains more ash. Zone 5 consists of a dark grayish-brown ashy silt loam A4 horizon and it represents the bottom of the midden deposits. Zone 6 is a $10 \mathrm{~cm}$ thick brown fine sandy silt $4 \mathrm{~A}$ horizon and it is clearly below the midden, while Zone 7 is a reddish-brown fine sandy silt $2 \mathrm{~B}$ horizon.

Profile 20 consists of two zones (Table G-2). Zone 1, an A horizon, extends from the surface to $12 \mathrm{~cm}$ below the surface and consists of a brown fine sand. Zone 2 is a reddish-brown fine sand $\mathrm{B}$ horizon with an unknown thickness.

\section{Interpretation}

Zones 2-5 in Profile 19 (Unit 6) are A1-A4 horizons and represent midden accumulations. Zone 6 in Profile 19 is an A horizon that correlates to Zone 1 in Profile 20 (Unit 5). Both of these zones are thin, $10-12 \mathrm{~cm}$ thick. The bottom zones in Profiles 19 and 20 are the same B horizon. Clearly the midden at 41BR65 was built on the surface instead of dug down into the surface and sediments accumulated above the ground level in this portion of the midden. The division of the midden deposit in Profile 19 into four zones indicates that this midden was probably used multiple times.

\section{BR87}

One profile was described at this site that is situated on a gentle toeslope in the Devils River floodplain. Profile 25 was described from Excavation Unit 2 within the central depression of the midden (Table G-3). A thin O horizon occurs in the upper $2 \mathrm{~cm}$. Between $2 \mathrm{~cm}$ and $10-15 \mathrm{~cm}$ is Zone 2 that consists of a dark gray sand silt with a few burned sandstone clasts. Zone $3(10-15$ to $40 \mathrm{~cm})$ is a black ashy sandy loam and abundant burned sandstone clasts. Zone 4 is a very dark grayish-brown ashy silt with up to one percent calcium carbonate filaments on root pores and a few burned sandstone clasts. Zone 5 is a dark red loam and represents a truncated 2Bt horizon. 
Table G-1. Profile19: Description for Unit 6, 41BR65

\begin{tabular}{|c|c|c|c|}
\hline $\mathrm{ZONE}$ & DEPTH & DESCRIPTION & HORIZON \\
\hline 1 & $0-1$ & $\begin{array}{l}\text { Grass, twigs, weed stalks. Lower boundary was smooth and } \\
\text { abrupt. }\end{array}$ & $\mathrm{O}$ \\
\hline 2 & $1-30$ & $\begin{array}{l}\text { Black (10YR2/1) slightly firm ashy silt loam, common rootlets } \\
\text { and burned sandstone cobbles and tabular fragments up to } \\
8 \mathrm{~cm} \text {, very common worm casts throughout }(75-80 \%) \text {, common } \\
\text { insect burrows probably termite, small } 1-1.5 \mathrm{~mm} \text { white flecks } \\
\text { that are not } \mathrm{CaCO}_{3} \text {, possibly related to insect burrows, } \\
\text { sample was collected, clear irregular lower boundary. }\end{array}$ & A1 \\
\hline 3 & $30-35 / 45$ & $\begin{array}{l}\text { Dark gray (10YR3/1) friable silt loam, common rootlets and } \\
\text { burned sandstone cobbles and tabular fragments up to } 10 \mathrm{~cm} \text {, } \\
80-90 \% \text { worm casts, common insect burrows, clear irregular } \\
\text { lower boundary. }\end{array}$ & $\mathrm{A} 2$ \\
\hline 4 & $\begin{array}{l}35 / 45^{-} \\
57 / 67\end{array}$ & $\begin{array}{l}\text { Dark gray (10YR4/1) friable, ashy silt loam, common burned } \\
\text { sandstone cobbles and tabular rocks up to } 18 \mathrm{~cm} \text {, large } \\
\text { fragment at the bottom, } 80-90 \% \text { worm casts, common insect } \\
\text { burrows, } 1 \% \mathrm{CaCO}_{3} \text { film on soil surface and on rock faces, few } \\
\text { rootlets, abrupt irregular lower boundary. }\end{array}$ & A3 \\
\hline 5 & $57 / 67-70$ & $\begin{array}{l}\text { Dark grayish-brown (10YR4/2) friable ashy silt loam, } \\
\text { common insect burrows, 80-90\% worm casts, clear smooth } \\
\text { lower boundary. }\end{array}$ & A4 \\
\hline 6 & $70-80$ & $\begin{array}{l}\text { Brown }(7.5 \text { Yr } 4 / 2) \text { friable, fine sandy silt. Slightly firm, } \\
\text { common insect burrows, large rodent burrow that extends } \\
\text { into Zone } 7 \text {, clear smooth lower boundary. }\end{array}$ & $2 \mathrm{~A}$ \\
\hline 7 & $80-85+$ & $\begin{array}{l}\text { Reddish-brown (5YR4/4) slightly firm fine sandy silt, common } \\
\text { insect burrows, } 40-50 \% \text { worm casts, lower boundary was not } \\
\text { observed. }\end{array}$ & $2 \mathrm{~B}$ \\
\hline
\end{tabular}

Table G-2. Profile20: Description for Unit 5 (north wall), 41BR65

\begin{tabular}{|l|l|l|l|}
\hline ZONE & DEPTH & DESCRIPTION & HORIZON \\
\hline 1 & $0-12$ & $\begin{array}{l}\text { Brown (7.5YR4.5/3/4) slightly firm fine sand, few small } \\
\text { sandstone pebbles up to 5cm, few rootlets, common worm } \\
\text { casts }(30-40 \%), \text { abrupt smooth-wavy lower boundary. }\end{array}$ & A \\
\hline 2 & $12+$ & $\begin{array}{l}\text { Reddish-brown (5YR4/4) firm fine sand, common small } \\
\text { sandstone subrounded to angular pebbles, lower boundary } \\
\text { was not observed. }\end{array}$ & B \\
\hline
\end{tabular}

\section{Interpretation}

Zones 2 through 4 represent the midden core sediments and the variations in burned sandstone and calcium carbonate can be used to suggest multiple events. The midden sits on a truncated 2Bt horizon and midden excavation may have truncated the surface of the $2 \mathrm{Bt}$ horizon.

\section{BR228}

This site consists of two burned rock midden complexes and five profiles were described from various excavation units. No backhoe trenches were excavated at this site. Profile 9 was described from Unit 1 , Profile 10 was observed from Unit 3, Profile 11 was taken from Unit 10, Profile 12 
Table G-3. Profile 25: Description for Unit 2, 41BR87

\begin{tabular}{|l|l|l|l|}
\hline ZONE & DEPTH & DESCRIPTION & HORIZON \\
\hline 1 & $0-2$ & $\begin{array}{l}\text { Grass stalks, finely chopped leaves, some small pebbles, } \\
\text { abrupt lower boundary. }\end{array}$ & O \\
\hline 2 & $2-10 / 15$ & $\begin{array}{l}\text { Dark gray (10YR3/1) fine sandy silt with weak coarse blocky } \\
\text { structure ranging to fine platy due to compaction, } 15-20 \% \\
\text { earth worm casts, rare small burned sandstone clasts up to } \\
\text { 2cm, common rootlets, few roots and insect burrows, clear } \\
\text { irregular lower boundary. }\end{array}$ & A1 \\
\hline 3 & $10 / 15-40$ & $\begin{array}{l}\text { Black (10YR2/1), fine ashy sandy loam, very common 70-80\% } \\
\text { earth worm casts, few rootlets, very common sandstone clasts } \\
\text { up to 13cm, some were cracked in place, clear irregular lower } \\
\text { boundary. }\end{array}$ & A2 \\
\hline 4 & $40-60$ & $\begin{array}{l}\text { Very dark grayish-brown (2.5Y3/1) ashy silt, common (1\%) } \\
\text { CaCO3 on rootlet pores, few burned sandstone clasts up to } \\
\text { 8cm, few rootlet pieces with small charcoal, clear irregular } \\
\text { lower boundary. }\end{array}$ & A3 \\
\hline 5 & $60+$ & $\begin{array}{l}\text { Dark red (2.5YR4/6) loam with weak coarse sub angular } \\
\text { blocky structure, 20\% earth worm and insect burrows and } \\
\text { casts, less than 1\% CaCO3 on rootlets pores, very small (less } \\
\text { than and equal to 1mm) angular chert pebble fragments, } \\
\text { CaCO } \text { on ped faces. Lower boundary was not observed. }\end{array}$ & 2 Bt \\
\hline
\end{tabular}

came from Unit 8, and Profile 13 describes the sediments in Unit 9. Units 1 and 3 were placed in the northeastern midden, while Units 8, 9, and 10 come from a midden complex in the southwest portion of the site. Unit 10 is higher in elevation, while Unit 8 is the lowest in elevation. Between the middens is a ridge of limestone bedrock with a number of bedrock mortars on both sides of the crest.

Profile 9 in Unit 1 presents $51 \mathrm{~cm}$ of black to very dark gray ashy silt loam to loam with varying amounts of burned sandstone clasts (Table G-4). These were subdivided into $\mathrm{A} 1, \mathrm{~A} 2$, and $\mathrm{A} 3$ horizons. These typical midden deposits sit directly on sandstone bedrock.

Profile 10 in Unit 3 illustrates a slightly different sequence (Table G-5). Here, $73 \mathrm{~cm}$ of black to dark gray silt loams to silts, divided into A1, A2, and A3 horizons, sit unconformably on a yellowish-brown fine sand $\mathrm{C}$ horizon. Bedrock was not reached in Unit 1, but it is probably not much deeper. The A horizons are clearly midden sediments. Importantly, no visible calcium carbonate had formed in these sediments.

Profile 11, from Unit 10, consists of $34 \mathrm{~cm}$ of black firm to friable ashy silt loam to fine sandy silt with few to common burned limestone clasts (Table G-6). The upper $34 \mathrm{~cm}$ consists of A1 and A2 horizons. Between 34-67 cm are B1 and $\mathrm{B} 2$ horizons. These are dark gray to dark grayish-brown friable sands and silts. These sit on sandstone bedrock. Again, no visible calcium carbonate was observed.

Profile 12, from Unit 8, consists of three A horizons (A1, A2, and A3) to a depth of $76 \mathrm{~cm}$ (Table G-7). These are dark gray to very dark gray ashy silt to silty sands with burned limestone in the $\mathrm{A} 1$ horizon but burned sandstone in the $\mathrm{A} 2$ horizon. Interestingly, the A2 and A 3 horizons have calcium carbonate filaments and the boundary between the A1 and A2 horizons is clear and irregular. Sandstone bedrock was observed at $76 \mathrm{~cm}$.

Profile 13 (Table G-8), Unit 9, is similar to Profile 12. Between $0-55 \mathrm{~cm}$ is very dark gray silty fine sand to silty sand-burned sandstone is present in both soil horizons. The A2 horizon displays calcium carbonate filaments. Below $55 \mathrm{~cm}$ is a light yellowish-brown to pale brown fine sand to silt. These sediments sit unconformably on sandstone bedrock at $83 \mathrm{~cm}$.

\section{Interpretation}

Clearly, the sediment descriptions at 41BR228 document typical burned rock midden sediments. These sediments sometimes sit on bedrock and sometimes sit on an older depositional unit. However, the presence of calcium carbonate filaments in Profiles 12 (Unit 8) and 13 (Unit 9) suggest that greater pedogenic development has occurred 
Table G-4. Profile 9: Description for Unit 1 (burned rock midden on saddle), 41BR228

\begin{tabular}{|l|l|l|l|}
\hline ZONE & DEPTH & DESCRIPTION & HORIZON \\
\hline 1 & $0-13$ & $\begin{array}{l}\text { Black (10YR2/1) friable silt loam ashy, common rootlets, } \\
\text { worm casts and burrows, few insect burrows and burned } \\
\text { limestone clasts up to 6cm, smooth lower boundary. }\end{array}$ & A1 \\
\hline 2 & $13-35$ & $\begin{array}{l}\text { Very dark gray (N3) very friable to loose loam, larger } \\
\text { sandstone rocks up to 12cm. }\end{array}$ & A2 \\
\hline 3 & $35-51$ & $\begin{array}{l}\text { Black (N2.5) very friable to loose loam, few rootlets, limestone } \\
\text { clasts 2-6 cm fewer than } 1 \%, \text { abrupt irregular lower } \\
\text { boundary. }\end{array}$ & A3 \\
\hline 4 & $51+$ & Sandstone Bedrock & $\mathrm{R}$ \\
\hline
\end{tabular}

Table G-5. Profile 10: Description for Unit 3 (burned rock midden on saddle), 41BR228

\begin{tabular}{|l|l|l|l|}
\hline ZONE & DEPTH & DESCRIPTION & HORIZON \\
\hline 1 & $0-11$ & $\begin{array}{l}\text { Black (2.5YR) friable silt loam, common rootlets, few burned } \\
\text { sandstone pebbles up to 5cm, clear abrupt lower boundary. }\end{array}$ & A1 \\
\hline 2 & $11-43$ & $\begin{array}{l}\text { Dark gray (N4) loose silt, common burned sandstone pebbles } \\
\text { up to 11cm, many discolored no distinct pattern, gradual } \\
\text { lower boundary. Tabular fragments }\end{array}$ & A2 \\
\hline 3 & $43-73$ & $\begin{array}{l}\text { Very dark gray (10YR3/1) loose silt loam, common sandstone } \\
\text { cobbles, some sandstone cobbles and tabular fragments, } \\
\text { abrupt smooth lower boundary. }\end{array}$ & A3 \\
\hline 4 & $73-80+$ & $\begin{array}{l}\text { Yellowish-brown (10YR5/4) fine sand, some worm casts, lower } \\
\text { boundary was not observed. }\end{array}$ & C \\
\hline
\end{tabular}

Table G-6. Profile 11: Description for Unit 10, 41BR228

(upper burned rock midden on slope below crest of ridge, highest unit)

\begin{tabular}{|l|l|l|l|}
\hline ZONE & DEPTH & DESCRIPTION & HORIZON \\
\hline 1 & $0-14$ & $\begin{array}{l}\text { Black (10YR2/1) firm ashy silt loam, common worm casts, few } \\
\text { insect burrows, common rootlets, few burned limestone clasts } \\
\text { up to 8cm, clear irregular lower boundary. }\end{array}$ & A1 \\
\hline 2 & $14-34$ & $\begin{array}{l}\text { Black (N2.5) friable ashy fine sand silt, common burned } \\
\text { sandstone clasts up to 17cm, common worm casts, clear } \\
\text { irregular lower boundary. }\end{array}$ & A2 \\
\hline 3 & $34-60$ & $\begin{array}{l}\text { Dark gray (10YR3/1) friable fine sand/silt, common worm } \\
\text { casts, clear irregular lower boundary. }\end{array}$ & B1 \\
\hline 4 & $60-67$ & $\begin{array}{l}\text { Dark grayish-brown (10YR4/2) slightly friable fine sand, } \\
\text { common earth worm casts, lower boundary not observed }\end{array}$ & B2 \\
\hline 5 & $67+$ & Sandstone Bedrock & R \\
\hline
\end{tabular}


Table G-7. Profile 12: Description for Unit 8, 41BR228, midden unit of Unit 10 above and Unit 9 below

(It appears that sediment was transported to these burned rock middens because there is not enough slope wash to contribute this much sediment to the middens.)

\begin{tabular}{|l|l|l|l|}
\hline ZONE & DEPTH & DESCRIPTION & HORIZON \\
\hline 1 & $0-20$ & $\begin{array}{l}\text { Dark gray (10YR3/1) silty- sand, common rootlets and worm } \\
\text { casts, few burned sandstone pebbles, clear irregular lower } \\
\text { boundary. }\end{array}$ & A1 \\
\hline 2 & $20-50$ & $\begin{array}{l}\text { Very dark gray (N3) common burned sandstone cobbles up to } \\
\text { 13cm, few rootlets. Common worm casts, dispersed 1\% CaCO } \\
\text { filaments throughout, clear irregular-to-smooth lower } \\
\text { boundary. }\end{array}$ & A2 \\
\hline 3 & $50-76$ & $\begin{array}{l}\text { Very dark gray (10YR3/1) ashy silt, much less CaCO } 3 \\
\text { filaments, few small up to 5cm burned limestone cobbles and } \\
\text { tabular fragments, abrupt irregular lower boundary. }\end{array}$ & A3 \\
\hline 4 & $76+$ & Sandstone bedrock & $\mathrm{R}$ \\
\hline
\end{tabular}

Table G-8. Profile 13: Description for Unit 9 (slightly below Unit 9), 41BR228

\begin{tabular}{|l|l|l|l|}
\hline ZONE & DEPTH & DESCRIPTION & HORIZON \\
\hline 1 & $0-23$ & $\begin{array}{l}\text { Very dark gray (10YR3/4) silty fine sand, common burned } \\
\text { sandstone clasts up to 11cm both cobbles and tabular, } \\
\text { common rootlets and worm casts, few roots, clear irregular } \\
\text { lower boundary. }\end{array}$ & A1 \\
\hline 2 & $23-55$ & $\begin{array}{l}\text { Very dark gray (10YR3/1) silty sand coarser than above, } \\
\text { dispersed CaCO filaments in common worm casts less than } \\
1 \% \text { friable, CaCO } 3 \text { was not on the root casts, common burned } \\
\text { sandstone tabular fragments and cobbles up to 16cm, abrupt } \\
\text { irregular lower boundary. }\end{array}$ & A2 \\
\hline 3 & $55-64$ & $\begin{array}{l}\text { Light yellowish-brown (10YR6/4) friable, fine sand, heavy } \\
\text { bioturbation, abrupt irregular lower boundary. }\end{array}$ & C1 \\
\hline 4 & $64-83$ & $\begin{array}{l}\text { Pale brown (10YR8/3) silt, common rodent and insect burrows } \\
\text { with dark gray (10YR4/1) fill, abrupt wavy-irregular lower } \\
\text { boundary. }\end{array}$ & C2 \\
\hline 5 & $83+$ & Sandstone bedrock & R \\
\hline
\end{tabular}

in the midden deposits from this portion of the site. The most reasonable interpretation is that these sediments have had more time to develop pedogenically and thus are older than those recorded in Profiles 9-11 (Units 1, 3, and 10).

\section{$41 \mathrm{BR} 250$}

Two profiles were described from 41BR250. Profile 18 describes the west walls of Units 2 and 3. These excavation units were excavated into the core of the midden. The midden was placed on an alluvial terrace adjacent a small stream. Profile 39 was collected from a backhoe trench excavated adjacent the midden into the terrace deposit.
Sediments described in Profile 18 were divided into five zones (Table G-9). The upper four zones are midden deposits and the lower, fifth zone represents the base of the midden. Zones 1 and 2 are A horizons consisting of dark gray firm to loose ashy silt with increasing amounts of burned sandstone down profile. Zones 3 and 4, between $31 / 45 \mathrm{~cm}$ to $100 \mathrm{~cm}$, are also midden deposits. These consist of dark gray loose ashy silt to dark gray very ashy friable silt. Both of these lower units have calcium carbonate filaments and films, while the upper zones lack calcium carbonate deposits. The lower zones also lack the worm casts common in the upper zones. 
Table G-9. Profile 18: Description for Units 2 and 3 (west wall), 41BR250

(burned rock midden on possible alluvial/ colluvial terrace that sloped more steeply than stream)

\begin{tabular}{|l|l|l|l|}
\hline ZONE & DEPTH & DESCRIPTION & HORIZON \\
\hline 1 & $0-20$ & $\begin{array}{l}\text { Dark gray (10YR3/2) slightly firm ashy silt, common rootlets, } \\
\text { few scattered burned sandstone clasts up to 11cm, common } \\
\text { worm casts and insect burrows, gradual irregular lower } \\
\text { boundary. }\end{array}$ & A1 \\
\hline 2 & $20-31 / 45$ & $\begin{array}{l}\text { Dark gray (10YR3/1) loose ashy silt, common burned } \\
\text { sandstone fragments up to 10cm, some cobbles and some } \\
\text { tabular, common rootlets and worm casts, few insect burrows, } \\
\text { clear irregular lower boundary. }\end{array}$ & A2 \\
\hline 3 & $31 / 45-77$ & $\begin{array}{l}\text { Dark gray (10YR3/1) loose ashy silt, less than 1\% CaCO } 3 \\
\text { filaments on root pores and films on ped faces, common } \\
\text { rootlets and burned sandstone fragments up to 12cm, few } \\
\text { roots, some large limestone tabular and cobbles at the base } \\
\text { and up to 23cm, clear- abrupt irregular lower boundary. }\end{array}$ & A3 \\
\hline 4 & $77-100$ & $\begin{array}{l}\text { Gray (N5) to dark gray (N4) very ashy friable silt, few small } \\
\text { burned sandstone pebbles up to 5cm, some tabular and } \\
\text { cobbles, CaCO } \text { filaments dispersed throughout and on rootlet } \\
\text { pores, clear smooth lower boundary. }\end{array}$ & A4 \\
\hline 5 & $100+$ & $\begin{array}{l}\text { Yellowish-brown (10YR5/4) to pale brown (10YR7/4) firm silty } \\
\text { loam, lower boundary not observed. }\end{array}$ & $2 \mathrm{~B}$ \\
\hline
\end{tabular}

Table G-10. Profile 39: Description for Backhoe Trench, 41BR250

\begin{tabular}{|l|l|l|l|}
\hline ZONE & DEPTH & DESCRIPTION & HORIZON \\
\hline 1 & $0-1$ & Grass, leaves and twigs, abrupt lower boundary. & O \\
\hline 2 & $1-7$ & $\begin{array}{l}\text { Brown (10YR5/3) very firm sandy loam, few rootlets and worm } \\
\text { casts(15\%), abrupt smooth lower boundary. }\end{array}$ & A1 \\
\hline 3 & $7-13$ & $\begin{array}{l}\text { Brown (10YR5/3) sandy loam with abundant small 1mm-3cm } \\
\text { sandstone fragments that were subrounded to angular, abrupt } \\
\text { smooth lower boundary sloping up towards the creek bank. }\end{array}$ & 2A \\
\hline 4 & $13-25$ & $\begin{array}{l}\text { Brown (10YR4/3) firm fine sandy silt with weak coarse } \\
\text { subangular blocky structure, common insect and worm } \\
\text { burrows (60-70\%), small complete snail shells in earth worm } \\
\text { casts over 1mm long, clear smooth lower boundary. }\end{array}$ & $3 \mathrm{~B}$ \\
\hline 5 & $25-67$ & $\begin{array}{l}\text { Dark grayish-brown (10YR4/2) fine sandy silt with weak } \\
\text { moderate subangular blocky structure, common charcoal } \\
\text { fragments, common (less than 1\%) CaCO } \text { on root pores, } \\
\text { gradual smooth lower boundary. }\end{array}$ & 3 B1 \\
\hline 6 & $67-145+$ & $\begin{array}{l}\text { Brown (10.5YR4/4) slightly firm fine sandy loam with weak } \\
\text { medium subangular blocky structure, fewer CaCO filaments } \\
\text { that decreases down the profile, few scattered subrounded to } \\
\text { rounded sandstone clasts up to 2cm in thickness, lower } \\
\text { boundary was not observed. }\end{array}$ & 3 B2 \\
\hline
\end{tabular}

Profile 39 exposed $145 \mathrm{~cm}$ of sediments (Table G-10). The upper $7 \mathrm{~cm}$ were recent alluvial or perhaps colluvial deposits. Below this was a thin buried $2 \mathrm{~A}$ horizon that probably correlates to the period of midden construction and use. This 2A horizon sits unconformably on alluvial terrace deposits that extend down to over $145 \mathrm{~cm}$. 


\section{Interpretation}

The deposits in Profile 18 represent typical sediments found in the cores of burned rock middens. Subtle differences, presence of calcium carbonate and absence of worm casts, between the upper two zones and lower two zones of midden deposits can be used to suggest that at least two periods of midden use are evident. The midden sits on a small alluvial terrace.

\section{$41 \mathrm{BR} 253$}

This site has two burned rock middens in a toeslope setting on an alluvial fan/small drainage complex. Four profiles were described. Profile 14 was described from Unit 10, Profile 15 was described from Unit 1, Profile 16 was taken from Unit 4, and Profile 17 was described from a cutbank exposure midway between the two middens in a small channel.

Three depositional units were identified in Profile 14 (Table G-11). Profile 14 begins with a thin, recent, sandy silt colluvial deposit which truncated a yellowish-brown fine sandy silt between $3-30 \mathrm{~cm}$. This deposit is a $2 \mathrm{~B}$ horizon with the $2 \mathrm{~A}$ horizon having been removed by recent erosion. Below the $2 \mathrm{~B}$ horizon, between $30-60 \mathrm{~cm}$, is a buried $3 \mathrm{~A}$ horizon composed of a grayish-brown sandy silt and this grades down into a brown fine sandy silt 3B horizon.

Profile 15 was described in Unit 1 which sampled the core of Feature 1. Three depositional units were identified (Table G-12). The upper $3 \mathrm{~cm}$ of deposits are recently deposited fine sand. This sediment has washed in from the inner edges of the central midden depression and forms the youngest depositional unit. The core of the midden deposit was divided into two zones (2A1 and 2A2). Between 3-19 cm was a very dark gray silt loam with small burned sandstone cobbles and common worm casts. Below this, between 19$42 \mathrm{~cm}$, was a very dark gray ashy and friable silt loam with common worm casts and larger burned sandstone cobbles and tabular fragments. The deepest depositional unit (3B) was a brown fine sandy silt that represents the base of the midden's core depression below $42 \mathrm{~cm}$ and extending to at least $51 \mathrm{~cm}$.

Profile 16 (Unit 4) describes sediments from the core of the second midden, Feature 2 (Table G-13). Two depositional units were identified in this profile. Zone 1, an A horizon, consists of black ashy silt loam between $0-42 \mathrm{~cm}$. The lower boundary is marked by flat tabular burned sandstone. Zone 2 is a gray ashy silt with common calcium carbonate filaments on root pores and roots. This probably represents a mixed basal unit of the midden. Zone 3, a $2 \mathrm{~B}$ horizon, consists of dark yellowish-brown to yellowish-brown silt loam. The boundary separating Zone 2 from Zone 3 is bioturbated but clear to abrupt. A burial was discovered in this midden and the pit fill is similar to Zone 1 .

Profile 17 was described in the cutbank of a small gully midway between the stream and the base of the escarpment and between the two middens. Three depositional units were identified (Table G-14). The youngest unit consists of a 10 $\mathrm{cm}$ thick light yellowish-brown silt loam. Below this and separated by an abrupt sloping and smooth lower boundary is a light yellowish-brown silt between $10-23 \mathrm{~cm}$. The lower boundary of this $2 \mathrm{C}$ horizon is very abrupt and marked by a thin layer of small pebbles and gravels at the contact. Both of these units are colluvial. The colluvial units sit on a buried

Table G-11. Profile 14: Description for Unit 10, 41BR253

(Unit excavated into the colluvial land form. No burned rock midden but there was a buried soil.)

\begin{tabular}{|l|l|l|l|}
\hline ZONE & DEPTH & DESCRIPTION & HORIZON \\
\hline 1 & $0-3$ & $\begin{array}{l}\text { Light yellowish-brown (2.5YR6/3) firm fine sandy silt, , few } \\
\text { rootlets, worm casts and insect burrows, clear wavy lower } \\
\text { boundary. }\end{array}$ & C \\
\hline 2 & $3-30$ & $\begin{array}{l}\text { Yellowish-brown (10YR5/4) firm fine sandy silt with weak } \\
\text { coarse sub angular blocky structure, few worm burrows and } \\
\text { casts, rootlets, and small1-3cm pebbles. }\end{array}$ & B \\
\hline 3 & $30-60$ & $\begin{array}{l}\text { Grayish-brown (10YR5/2) slightly firm sandy silt, CaCO } 3 \\
\text { filaments less than 1\% in worm casts and rootlet pores, } \\
\text { abrupt smooth lower boundary. }\end{array}$ & $\mathrm{A}$ \\
\hline 4 & $60-66+$ & $\begin{array}{l}\text { Brown (10YR5/3) friable fine sandy silt, CaCO filaments less } \\
\text { than above, common worm casts, filament on rootlet pores, } \\
\text { abrupt smooth lower boundary. }\end{array}$ & $\mathrm{B}$ \\
\hline
\end{tabular}


Table G-12. Profile 15: Description for Unit 1, 41BR253

(lower burned rock midden on same "surface" as Profile 14)

\begin{tabular}{|l|l|l|l|}
\hline ZONE & DEPTH & DESCRIPTION & HORIZON \\
\hline 1 & $0-3$ & Brown (10YR5/3) fine sand, clear smooth lower boundary. & C \\
\hline 2 & $3-19$ & $\begin{array}{l}\text { Very dark gray (10YR3/2) very firm silt loam with medium } \\
\text { moderate sub angular blocky structure, burned sandstone } \\
\text { cobbles 5cm, common worm casts, clear irregular lower } \\
\text { boundary. }\end{array}$ & $2 \mathrm{~A} 1$ \\
\hline 3 & $19-42$ & $\begin{array}{l}\text { Very dark gray (10YR3/2) ashy friable silt loam with fine } \\
\text { weak subangular blocky structure, common CaCO } \text { filaments }_{3} \text { fo dispersed throughout and along rootlet pores, common } \\
\text { worm casts, few burned rock sandstone cobbles and tabular } \\
\text { fragments up to 17cm, irregular clear-abrupt lower boundary. }\end{array}$ & 2 A2 \\
\hline 4 & $42-51+$ & $\begin{array}{l}\text { Brown (10YR5/3) fine sandy silt, well developed CaCO } \mathrm{CO}_{3} \\
\text { filaments, lower boundary not observed. }\end{array}$ & $3 \mathrm{~B}$ \\
\hline
\end{tabular}

Table G-13. Profile 16: Description for Unit 4, 41BR253

(in upper burned rock midden completely turbated by earthworms)

\begin{tabular}{|l|l|l|l|}
\hline ZONE & DEPTH & DESCRIPTION & HORIZON \\
\hline 1 & $0-42$ & $\begin{array}{l}\text { Black (N2.5) ashy silt loam, totally turbated by worms } \\
\text { throughout zone, common burned limestone with flat tabular } \\
\text { pieces at the base, common rootlets, abrupt wavy lower } \\
\text { boundary. }\end{array}$ & A \\
\hline 2 & $42-54$ & $\begin{array}{l}\text { Gray (10YR5/1) ashy silt, common filaments on roots and } \\
\text { rootlet pores, few small up to 6cm burned sandstone } \\
\text { fragments some oxidized red, clear-abrupt highly irregular } \\
\text { lower boundary due to bioturbation of roots and worms. }\end{array}$ & B \\
\hline 3 & $54-60+$ & $\begin{array}{l}\text { Dark yellowish-brown (10YR4/4) to yellowish-brown } \\
\text { (10YR5/4) silt loam, common but less than 1\% CaCO film } \\
\text { and filaments on ped faces and rootlet pores, lower boundary } \\
\text { not observed. }\end{array}$ & 2 B \\
\hline
\end{tabular}

soil (3A horizon). The buried soil consists of a grayish-brown silt between $23-65 \mathrm{~cm}$. A related B horizon is below the $3 \mathrm{~A}$ horizon, it is composed of a yellowish-brown sandy loam, and it extends to the bottom of the cutbank at $95 \mathrm{~cm}$.

\section{Interpretation}

Profiles 14 and 17 describe similar depositional units with colluvium sitting on a buried soil. Profile 15 , in the midden, clearly cuts through these deposits and its basal depositional unit can be correlated to the 3B horizons in Profiles 14 and 17. The Profile 16 midden is perched on an elevated landform and cannot be correlated reliably. An important point is that the midden sediments in both middens, but especially in Profile 16, are highly turbated by earthworms. In fact, in Profile 16 virtually all the fine-grained sediment had been excreted by earthworms.

\section{BR261}

Two profiles were described at 41BR261. This site sits on a mid-slope of the escarpment that overlooks Pecan Bayou. Profile 26 was collected from a nickpoint cutbank that was eroding a colluvial fan deposit on the north-facing escarpment slope. Profile 37 was described from a backhoe trench cut into a second and separate colluvial fan across a small gully from Profile 26. The surfaces of these two alluvial fans were sloping at different angles. The Profile 26 surface is estimated to be $\sim 15$ degrees from horizontal and the Profile 37 slope is $\sim 10$ degrees.

In Profile 26, between 0-25 cm, was a brown loam with small sandstone and chert pebbles (Table G-15). From $25-95+\mathrm{cm}$ was a yellowish-brown to light yellowish-brown silt loam to sandy silt with sublayers of colluvial gravel 
stringers. The upper zone is an A horizon and the lower zone is a $\mathrm{B}$ horizon.

Profile 37 consisted of a thin, recent brown loam A horizon that sits unconformably on three $2 \mathrm{Bw}$ horizons between $8-55 \mathrm{~cm}$ of a deeply weathered reddish-brown clay loam with varying amounts of sandstone, chert, and quartz pebbles (Table G-16). The structure is well developed and ranges from crumb to moderate subangular blocky. Below $55 \mathrm{~cm}$ and extending to $95 \mathrm{~cm}$ is a brown clay loam 3B horizon with abundant calcium carbonate clay films impregnating soil peds and calcium carbonate coatings on the ventral sides of pebbles.

\section{Interpretation}

Even though both profiles were described in colluvial fan sediments near to each other, the sediments in these two profiles differ greatly in terms of weathering and pedogenic development. Clearly, the sediments in Profile 37 are much older than those observed in Profile 26. Additionally, the slopes of these two colluvial features differ as well. The older fan (Profile 37) displays a 3-5 degree less steep slope than the younger fan (Profile 26). It is clear that the deposits in Profile 37 are among the oldest sediments observed in the described deposits at Camp Bowie. These data, along with the descriptions from 41BR415 and 41BR420, can be used to suggest that the accumulation of colluvial/alluvial fan deposits occurred in episodic events in a punctuated fashion.

Table G-14. Profile 17: Description for Cutbank, 41BR253

(in erosional gully midway between stream and base of escarpment and between two middens)

\begin{tabular}{|l|l|l|l|}
\hline ZONE & DEPTH & DESCRIPTION & HORIZON \\
\hline 1 & $0-10$ & $\begin{array}{l}\text { Light yellowish-brown (10YR6/4) silt loam, 20-50\% small } \\
\text { angular to sub rounded pebbles up to 6cm some tabular, } \\
\text { pebbles form interlocking lenses, few rootlets, abrupt smooth } \\
\text { sloping lower boundary, colluvium. }\end{array}$ & C \\
\hline 2 & $10-23$ & $\begin{array}{l}\text { Light yellowish-brown (10YR6/4) silt with weak coarse } \\
\text { subangular blocky structure, abundant insect burrows } \\
\text { (termites), very abrupt smooth sloping lower boundary } \\
\text { marked by thin layer of small pebbles and gravels at contact. }\end{array}$ & $2 \mathrm{C}$ \\
\hline 3 & $23-65$ & $\begin{array}{l}\text { Grayish-brown (10YR5/2) silt with fine sand with coarse } \\
\text { weak sub angular blocky structure, common insect burrows } \\
\text { some worm casts, gradual and smooth lower boundary. }\end{array}$ & $3 \mathrm{~A}$ \\
\hline 4 & $65-95+$ & $\begin{array}{l}\text { Yellowish-brown (10YR5/4) firm sandy loam with weak } \\
\text { coarse sub angular blocky structure, few gravels encountered, } \\
\text { lower boundary not observed. }\end{array}$ & $3 \mathrm{~B}$ \\
\hline
\end{tabular}

Table G-15. Profile 26: Description for Cutbank, 41BR261

(south of the site on a sloping [15-20 degrees] surface leading from escarpment smooth surface)

\begin{tabular}{|l|l|l|l|}
\hline ZONE & DEPTH & DESCRIPTION & HORIZON \\
\hline 1 & $0-25$ & $\begin{array}{l}\text { Brown (10YR5/3. firm loam with coarse weak sub angular } \\
\text { blocky structure, common 20-25\% small sub rounded to } \\
\text { angular sandstone and chert pebbles, clear wavy lower } \\
\text { boundary. }\end{array}$ & A \\
\hline 2 & $25-95+$ & $\begin{array}{l}\text { Yellowish-brown (10YR5/4) firm silt loam with weak coarse } \\
\text { subangular blocky structure, few (less than 1\%) CaCO } 3 \\
\text { filaments on pores, sublayers of colluvial gravel that was } \\
\text { light yellowish-brown (10YR6/4) fine grain sublayers } \\
\text { composed of fine sandy silt, common tabular and cobble clasts } \\
\text { up to 7cm but most being 2-3cm. }\end{array}$ & B \\
\hline
\end{tabular}


Table G-16. Profile 37: Description for Backhoe Trench, 41BR261

(backhoe trench cut into older oxidized fan deposit across gully from younger deposit)

\begin{tabular}{|c|c|c|c|}
\hline ZONE & DEPTH & DESCRIPTION & HORIZON \\
\hline 1 & $0-8$ & $\begin{array}{l}\text { Brown (7.5YR4/3) firm loam with weak medium subangular } \\
\text { blocky structure, common small up to } 3 \mathrm{~cm} \text { sub rounded to } \\
\text { angular sandstone and quartz clasts, clear smooth lower } \\
\text { boundary sloping with the angle of the fan. }\end{array}$ & A \\
\hline 2 & $8-25$ & $\begin{array}{l}\text { Reddish-brown (5YR4/4) clay loam with coarse crumb medium } \\
\text { angular blocky structure, common small to medium up to } 5 \mathrm{~cm} \\
\text { subrounded to angular sandstone and quartz clasts (most in } \\
\text { the } 1 \mathrm{~cm} \text { range), fairly well developed ped faces, gradual } \\
\text { smooth lower boundary. }\end{array}$ & $2 \mathrm{Bw} 1$ \\
\hline 3 & $25-40$ & $\begin{array}{l}\text { Reddish-brown (5YR4/4) clay loam with medium moderate } \\
\text { subangular blocky structure, few } \mathrm{CaCO}_{3} \text { filaments in root } \\
\text { pores, gradual smooth lower boundary. }\end{array}$ & 2Bw2 \\
\hline 4 & $40-55$ & $\begin{array}{l}\text { Reddish-brown (5YR4/4) clay loam, increased } \mathrm{CaCO}_{3} \text { filaments } \\
\text { in root pores and mostly on ped faces (about } 1 \% \text { ), gradual } \\
\text { smooth lower boundary. }\end{array}$ & $2 \mathrm{Bw} 3$ \\
\hline 5 & $55-95$ & $\begin{array}{l}\text { Brown (7.5YR5/4) clay loam with abundant (50-75\%) } \mathrm{CaCO}_{3} \\
\text { films, CaCO3 films totally enclose and infiltrate peds, common } \\
\text { subrounded to angular (mostly subrounded) sandstone and } \\
\text { chert cobbles up to 8cm, no visible sorting or layering. }\left(\mathrm{CaCO}_{3}\right. \\
\text { cemented terrace deposit.) Thin } \mathrm{CaCO}_{3} \text { coating on cobbles on } \\
\text { ventral and dorsal side. } 65 \mathrm{~cm} \text { large cobble had coating on } \\
\text { ventral surfaces. }\end{array}$ & $3 \mathrm{~B}$ \\
\hline
\end{tabular}

\section{BR276}

Only one profile was described from 41BR276 (Table G-17). This site in on a low ridge crest on an upland slope. A single unit of brown sandy loam was found $20 \mathrm{~cm}$ above the sandstone bedrock at this site. These deposits are probably colluvial sediments that have washed down the slope and ridge crest with very little development of soil horizons.

\section{IBR415}

Profiles 7, 8, and 38 were recorded in the vicinity of this site. Site 41BR415 consists of a single small burned rock midden. The midden occupies an elevated knoll on a large, thick dissected alluvial fan deposit. The midden matrix is composed of 40-70 percent sediment and sediments must have been transported. At 41BR415, an alluvial fan formed on the east facing sandstone escarpment overlooking Pecan

Table G-17. Profile 36: Description for 41BR276

(northeast of stock pond on ridge crest-possibly on road in far west. On slight crest of gradual upland slope.)

\begin{tabular}{|l|l|l|l|}
\hline ZONE & DEPTH & DESCRIPTION & HORIZON \\
\hline 1 & $0-20$ & $\begin{array}{l}\text { Brown (10YR5/3) sandy loam, common small subangular } \\
\text { friable sandstone clasts up to } 3 \mathrm{~cm}, \text { few } \mathrm{CaCO}_{3} \text { filaments much } \\
\text { less than } 1 \% .\end{array}$ & B \\
\hline
\end{tabular}


Bayou in the distance. The soils are mapped as Throck series and the A horizon is eroded over most of the alluvial fan.

Profile 7 describes the sediments observed in a deep cutbank of an arroyo (Table G-18). The sediments were divided into five soil horizons. The A horizon is not well developed, retains evidence of the original depositional structure, and is often removed by erosion on the fan surface in other areas. $\mathrm{B} 1$ and $\mathrm{B} 2$ horizons are $50 \mathrm{~cm}$ thick and are frequently exposed by erosion on the surface of the fan deposit. The $\mathrm{C}$ horizons are over $110 \mathrm{~cm}$ thick and retain evidence of the original deposition structures in the form of gravel stringers.

Profile 8 was taken from Excavation Unit 2 within the midden (Table G-19). The A horizon documents the sediments within the midden. Given that the midden occurs on a small knoll, the sediment in Zone 1 may have been transported to the locale during the construction and use of the midden. Below these deposits are $2 \mathrm{~B} 1$ and $2 \mathrm{~B} 2$ horizons. The $2 \mathrm{~B} 1$ horizon is intensively turbated by rodents and less so by worms and insects. It is possible that this horizon is the same A horizon as in Profile 7. The 2B2 horizon consists of a firm silt loam with subangular blocky structure. This can be correlated to the B horizons in Profile 7.
Profile 38 was recorded in a backhoe trench excavated on a flat knoll on the crest of the alluvial fan immediately north of the dirt road that runs east-west through the site (Table G-20). At least two depositional units were observed, but the sediments in the lower portion of Zone 7 and Zone 8 were only described from samples collected out of the backhoe bucket. The upper A, B1, and B2 horizons are sandy loams to loams extending to a depth of $42 \mathrm{~cm}$. However, between $42-66 \mathrm{~cm}$ was a well-developed pedocalcrete. The pedocalcrete capped over $350 \mathrm{~cm}$ of alluvial fan deposits. Bedrock had not been reached when the backhoe trench was terminated at $420 \mathrm{~cm}$.

\section{Interpretation}

The sediments at 41BR415 show that a large thick alluvial fan accumulated on the east facing slope of the sandstone escarpment in at least two phases. The presence of a welldeveloped pedocalcrete strongly suggests that the lower deposits on this fan are probably Late Pleistocene in age. The upper sediments are considerably younger. The midden was placed on the fan deposits and additional sediment was probably transported to the midden locale in order to facility the cooking feature.

Table G-18. Profile 7: Description for Cutbank near 41BR415

(description of profile across road from 41BR415 in deep cutbank of arroyo)

\begin{tabular}{|l|l|l|l|}
\hline ZONE & DEPTH & DESCRIPTION & HORIZON \\
\hline 1 & $0-30$ & $\begin{array}{l}\text { Brown (10YR5/3) slightly firm sandy loam with very weak } \\
\text { coarse sub-blocky structure, common rootlets, insect and } \\
\text { worm burrows and casts, scattered small 1-10mm sub } \\
\text { rounded pebbles, clear smooth lower boundary. }\end{array}$ & A \\
\hline 2 & $30-52$ & $\begin{array}{l}\text { Yellowish-brown (10YR5/4) slightly firm (more firm than } \\
\text { above) sandy loam with weak coarse subangular blocky } \\
\text { structure, dispersed gravel less than 1\%, common insect } \\
\text { burrows and worm casts, lightly cemented less than 1\% } \\
\text { CaCO filaments, clear smooth lower boundary. }\end{array}$ & B1 \\
\hline 3 & $52-80$ & $\begin{array}{l}\text { Yellowish-brown (10YR5/4) firm sandy loam with moderate } \\
\text { medium subangular blocky structure, increasing CaCO3 on } \\
\text { ped faces, stronger cementation, horizontal gravel stringer } \\
79-80 c m, \text { gravel size up to 5cm, gradual smooth lower } \\
\text { boundary. }\end{array}$ & B2 \\
\hline 4 & $80-135$ & $\begin{array}{l}\text { Light yellowish-brown (10YR6/4) very firm sandy loam with } \\
\text { moderate medium subangular blocky structure, scattered } \\
\text { pebbles 2cm in diameter, common insect, worm and root } \\
\text { casts, gradual smooth lower boundary. }\end{array}$ & C1 \\
\hline 5 & $135-190$ & $\begin{array}{l}\text { Light brown (7.5YR6/4) sandy loam with medium moderate } \\
\text { prismatic structure, scattered 1\% small pebbles 2cm, some as } \\
\text { transported CaCO } 3 \text { nodules, common worm and root casts, } \\
\text { lower boundary not observed. }\end{array}$ & C2 \\
\hline
\end{tabular}


Table G-19. Profile 8: Description for Unit 2, 41BR415

(Midden occupies elevated knoll on large dissected alluvial fan deposit. Midden matrix composed of 40-70\% sediment and sediments must have been transported. Fan deposit has thin incepts soil covering the whole fan.)

\begin{tabular}{|l|l|l|l|}
\hline ZONE & DEPTH & DESCRIPTION & HORIZON \\
\hline 1 & $0-30$ & $\begin{array}{l}\text { Dark gray (10YR3/1) slightly firm, ashy sandy loam, } \\
\text { abundant worm casts, common rootlets, few small 1-6cm } \\
\text { burned rocks more common } 50 \text { cm east at the bottom there } \\
\text { are larger tabular burned rocks, abrupt, smooth to irregular } \\
\text { lower boundary. }\end{array}$ & A \\
\hline 2 & $30-58$ & $\begin{array}{l}\text { Dark gray (10YR4/1) slightly firm sandy loan, dispersed 1-2\% } \\
\text { CaCO3 filaments throughout, few roots and rootlets, common } \\
\text { burned rock 1-9 cm. common worm casts and insect burrows } \\
\text { but less than above, intensively burrowed by rodents, highly } \\
\text { irregular, clear to abrupt lower boundary. }\end{array}$ & B \\
\hline 3 & $\begin{array}{l}\text { Pale brown (10YR8/4) firm silt loam with medium moderate } \\
\text { sub angular blocky structure, common 1.5-2\% CaCO } \\
\text { filaments along root casts and ped faces, common insect and } \\
\text { worm burrows and casts with gray (10YR5/1) silt loam, less } \\
\text { than 1\% sub rounded 1-4cm chert pebbles with CaCO } \\
\text { coating on ventral surface, } 15-20 \% \mathrm{CaCO}_{3} \text { nodules, lower } \\
\text { boundary was not observed. }\end{array}$ & $2 \mathrm{~B}$ \\
\hline
\end{tabular}

Table G-20. Profile 38: Description for Backhoe Trench, 41BR415

\begin{tabular}{|c|c|c|c|}
\hline $\mathrm{ZONE}$ & DEPTH & DESCRIPTION & HORIZON \\
\hline 1 & $0-1$ & Grass stalks, leaves, and weeds. & $\mathrm{O}$ \\
\hline 2 & $1-16$ & $\begin{array}{l}\text { Brown (10YR5/3) slightly firm sandy loam with coarse } \\
\text { medium weak subangular blocky structure, common }(40-50 \%) \\
\text { worm burrows and casts, few subrounded sandstone and chert } \\
\text { pebbles up to } 1 \mathrm{~cm} \text {, clear smooth lower boundary. }\end{array}$ & $\mathrm{A}$ \\
\hline 3 & $16-25$ & $\begin{array}{l}\text { Light yellowish-brown (10YR6/4) Friable loam, common worm } \\
\text { burrows and casts }(60-70 \%), 2-4 \% \text { loose } \mathrm{CaCO}_{3} \text { nodules } \\
\text { probably deposited as clasts, } \mathrm{CaCO}_{3} \text { filaments on root pores } \\
\text { (less than } 1 \% \text {, clear smooth sloping lower boundary. }\end{array}$ & B1 \\
\hline 4 & $25-42$ & $\begin{array}{l}\text { Light yellowish-brown (10YR6/4) Same as above except } \\
\text { increase in } \mathrm{CaCO}_{3} \text { pebbles to } 20 \% \text {, abrupt smooth lower } \\
\text { boundary. }\end{array}$ & $\mathrm{B} 2$ \\
\hline 5 & $42-66$ & $\begin{array}{l}\text { White extremely firm stage } 4 \mathrm{CaCO}_{3} \text { with tabular nodules, } \\
\text { sandstone and chert clasts up to } 10 \mathrm{~cm} \text {, thick } \mathrm{CaCO}_{3} \text { rinds on } \\
\text { sandstone clasts, abrupt smooth lower boundary. }\end{array}$ & $2 \mathrm{~B} 1$ \\
\hline 6 & $66-93$ & $\begin{array}{l}\text { Reddish-yellow (7.5YR7/6) slightly firm silt with coarse to } \\
\text { moderate crumb structure, clear smooth lower boundary. }\end{array}$ & $2 \mathrm{~B} 2$ \\
\hline 7 & $93-110$ & $\begin{array}{l}\text { Reddish-yellow (7.5YR6.5/6) friable silt with fine subangular } \\
\text { blocky structure, lower boundary not observed. }\end{array}$ & $2 \mathrm{~B} 3$ \\
\hline 8 & $110-420+$ & $\begin{array}{l}\text { Reddish-yellow }(7.5 \mathrm{YR} 6 / 6) \text { friable silt, } \mathrm{CaCO}_{3} \text { filaments and } \\
\text { small hard nodules scattered throughout. SAMPLE } 1 \text { taken } \\
\text { from bucket } 3.9 \mathrm{~m} \text {, yellowish-brown }(7.5 \mathrm{YR} 7 / 6) \text { with } \mathrm{CaCO}_{3} \\
\text { nodules up to } 5 \mathrm{~cm} \text {. SAMPLE } 2 \text { taken } 420 \mathrm{~cm} \text { consists of large } \\
\text { gravel and cobbles up to } 30 \mathrm{~cm} \text { diameter. }\end{array}$ & $2 \mathrm{~B} 4$ \\
\hline
\end{tabular}




\section{$41 \mathrm{BR} 420$}

Two profiles were described in 41BR420. This site is at the base of the escarpment that overlooks the Pecan Bayou valley. Profile 27 was taken from colluvial fan sediments exposed in Unit 1 in the central depression of a burned rock midden, while Profile 29 was collected from a shallow cutbank in an adjacent colluvial fan.

The sediments in Profile 27 were divided into six zones (Table G-21). Zone 1, 0-1 cm, is an O horizon. Zone 2, between $1-25 \mathrm{~cm}$, is a dark gray ashy fine sandy silt. Zone 3 is a very dark gray ashy silt loam with medium (up to $18 \mathrm{~cm}$ ) tabular and cobbled burned sandstone. Zone 4, 41-49 cm, is a very dark gray ashy silt with larger (up to $32 \mathrm{~cm}$ ) burned sandstone clasts. Zone 5 grades from a very dark grayishbrown to a brown silt loam with abundant burned sandstone clasts. Zone 5 sits unconformably on Zone 6 at $57 \mathrm{~cm}$. Zone 6 is a yellow fine sandy silt. Zones $2-5$ are A horizons and Zone 6 is a $2 \mathrm{~B}$ horizon.

Sediments in Profile 29 were divided into two zones (Table G-22). The first zone, $0-8 \mathrm{~cm}$, is a yellowish-brown fine silty sand. It grades into a brown fine silty sand with large yellowish-red to brownish-yellow manganese nodules. These give the zone a highly weathered appearance.

Table G-21. Profile 27: Description for Unit 1, 41BR420

\begin{tabular}{|l|l|l|l|}
\hline ZONE & DEPTH & DESCRIPTION & HORIZON \\
\hline 1 & $0-1$ & Common grass stalks, small leaf fragments and twigs & O \\
\hline 2 & $1-25$ & $\begin{array}{l}\text { Dark gray (10YR4/1) ashy fine sandy silt, depleted of CaCO } 3 \\
\text { (no effervescence) clear smooth-wavy lower boundary. }\end{array}$ & A1 \\
\hline 3 & $25-41$ & $\begin{array}{l}\text { Very dark gray (10YR3/1) ashy slightly firm silt loam, very } \\
\text { common } 60-70 \% \text { worm casts, 10\% medium 1-2cm insect } \\
\text { burrows with smooth linings, common tabular and cobbled } \\
\text { burned sandstone clasts up to 18cm, common rootlets, few } \\
\text { roots, sandstone fragments on horizon layering toward } \\
\text { bottom, clear-abrupt smooth-irregular lower boundary. }\end{array}$ & A2 \\
\hline 4 & $41-49$ & $\begin{array}{l}\text { Very dark gray (10YR3/1) ashy friable silt, common large } \\
\text { tabular fragments up to 32cm, few small charcoal chunks, } \\
\text { few rootlets and worm casts (10-20\%), CaCO3 filaments on } \\
\text { rock faces much less than 1\%, clear smooth lower boundary. }\end{array}$ & A3 \\
\hline 5 & $49-57$ & $\begin{array}{l}\text { Very dark grayish-brown (10YR3/2) silt loam grading down } \\
\text { profile to brown (10YR43) silt loam, lower layer of rocks, 40- } \\
\text { 50\% earth worm and insect casts, lower sediments turbated } \\
\text { by earthworms, clear wavy lower boundary. }\end{array}$ & A4 \\
\hline 6 & $57-63+$ & $\begin{array}{l}\text { Yellow (10YR7/6) fine firm sandy silt, lower boundary not } \\
\text { observed. }\end{array}$ & $2 \mathrm{~B}$ \\
\hline
\end{tabular}

Table G-22. Profile 29: Description for Cutbank north of 41BR420

(Adjacent fan slope to site 41BR420 with slightly greater than 2-3 degrees sloping angle than 41BR420. Surface of fan covered with red oxidized sediments and weathered sandstone. In shallow cutbank.)

\begin{tabular}{|l|l|l|l|}
\hline ZONE & DEPTH & DESCRIPTION & HORIZON \\
\hline 1 & $0-8$ & $\begin{array}{l}\text { Yellow brown (10YR5/6) firm silty fine sand with very weak } \\
\text { coarse sub angular blocky structure, few medium 2-6cm } \\
\text { sandstone clasts marking lower boundary, clear smooth-wavy } \\
\text { lower boundary. }\end{array}$ & C \\
\hline 2 & $8-50+$ & $\begin{array}{l}\text { Brown (7.5YR5/6) very firm silty fine sand with weak coarse } \\
\text { sub angular blocky structure, common (15\%) worm casts and } \\
\text { insect burrows, few small and scattered up to 4cm sandstone } \\
\text { clasts subrounded. Lower part of zone had large yellowish- } \\
\text { red (5YR5/6) to brownish yellow (10YR6/8) manganese (5mm) } \\
\text { nodules, lower boundary not observed. }\end{array}$ & 2 B \\
\hline
\end{tabular}




\section{Interpretation}

Profile 27 (Unit 1) exposed four zones within the burned rock midden deposit. These variations probably reflect different use periods of the midden. Also, every zone in the midden was highly turbated by insects and earthworms. The fan sediments exposed in the cutbank and described in Profile 29 are different from the basal fan sediments described in Profile 27. Also, as similar to the fan deposits described at 41BR261, the two fans here at 41BR420 have slightly different surface slope angles. The soil development and surface slope angles can be used to suggest that these are two separate fans that accumulated at different times.

\section{$41 B R 433$}

Three profiles were described at 41BR433. This is a site with a single burned rock midden composed primarily of limestone. It was the only limestone midden described and as such provides important data for a comparison between sandstone and limestone middens. This site is situated on a flat limestone bench overlooking a small intermittent tributary of Lewis Creek.
Profile 33 was collected from Unit 2 and the sediments were divided into four zones (Table G-23). Zone 1 is a $1 \mathrm{~cm}$ thick $\mathrm{O}$ horizon. Zones 2 and 3 are midden A horizon deposits between $1-58 \mathrm{~cm}$, and consist of black ashy silt. The primary difference is the presence of calcium carbonate filaments in Zone 3. The midden sits unconformably on Zone 4 which is a dark yellowish-brown 2B horizon silt loam found within depressions and cavities in the limestone bedrock.

Profile 34 was in Unit 1. This unit was placed in the central depression of the midden. One zone was described here (Table G-24). From the surface to $58 \mathrm{~cm}$ is a black silt loam which sits directly on limestone bedrock.

Profile 35 is off the midden in Unit 4 and this provides a description of a non-anthropogenic profile (Table G-25). The upper $1 \mathrm{~cm}$ is an $\mathrm{O}$ horizon and this is followed by a $15 \mathrm{~cm}$ thick A1 horizon consisting of dark grayish-brown sand. Below this a dark brown A2 horizon of sandy silt with burned limestone. This presents the occupation horizon at the site. The A horizon is unconformably on a brown sandy loam that is classified as a $2 \mathrm{~B}$ horizon.

Table G-23. Profile 33: Description for Unit 2, 41BR433

\begin{tabular}{|l|l|l|l|}
\hline ZONE & DEPTH & DESCRIPTION & HORIZON \\
\hline 1 & $0-1$ & Leaves, grass stalks, and twigs. & O \\
\hline 2 & $1-35$ & $\begin{array}{l}\text { Black (N2.5) firm ashy silt, abundant worm casts 80\%, } \\
\text { common rootlet and limestone fragments and cobbles up to } \\
15 \% \text { cm, clear irregular lower boundary. }\end{array}$ & A1 \\
\hline 3 & $35-58$ & $\begin{array}{l}\text { Black(10YR2/1) slightly firm ashy silt, few (less than 1\%) } \\
\text { CaCO filaments on rock faces and on rootlet pores, common } \\
\text { rootlets, few roots and burned sandstone fragments, abrupt } \\
\text { irregular lower boundary. }\end{array}$ & A2 \\
\hline 4 & $58+$ & $\begin{array}{l}\text { Dark Yellowish-brown (10YR4/6) silt loam found in cavity of } \\
\text { limestone bedrock, very abrupt irregular lower boundary. }\end{array}$ & $2 \mathrm{~B}$ \\
\hline
\end{tabular}

Table G-24. Profile 34: Description for Unit 1 (west wall), 41BR433 (profile in recent pit fill)

\begin{tabular}{|l|l|l|l|}
\hline ZONE & DEPTH & DESCRIPTION & HORIZON \\
\hline 1 & $0-58$ & $\begin{array}{l}\text { Black (N2.5) friable medium coarse crumb structure, 50-60\% } \\
\text { earth worm casts, few scattered burned limestone and } \\
\text { sandstone fragments less than } 5 \%, \text { most are } 5 \mathrm{~cm}, \text { toward } \\
\text { bottom few } \mathrm{CaCO}_{3} \text { filament on root pores much less than } 1 \% .\end{array}$ & A \\
\hline
\end{tabular}


Table G-25. Profile 35: Description for Unit 4 (east wall), 41BR433

\begin{tabular}{|l|l|l|l|}
\hline ZONE & DEPTH & DESCRIPTION & HORIZON \\
\hline 1 & $0-1$ & Grass stalks, leaves and weed stalks. & O \\
\hline 2 & $1-16$ & $\begin{array}{l}\text { Dark grayish-brown (10YR3/2) firm fine sand with weak } \\
\text { coarse subangular blocky structure, few insect burrows and } \\
\text { worm casts (15-20\%), clear smooth lower boundary sloping } \\
\text { above burned rock. }\end{array}$ & A \\
\hline 3 & $16-25$ & $\begin{array}{l}\text { Dark brown (10YR3/3) fine sandy silt with thin lenses of } \\
\text { burned limestone, few roots and insect burrows (termites), } \\
\text { clear smooth lower boundary sloping above burned rock. }\end{array}$ & $2 \mathrm{~A}$ \\
\hline 4 & $25-45+$ & $\begin{array}{l}\text { Brown (7.5YR4/4) very firm fine sandy loam with coarse weak } \\
\text { subangular blocky structure, common (less than 1\%) CaCO } 3 \\
\text { filaments on root pores that increase down profile, down } \\
\text { profile clays formed on ped faces, lower boundary was not } \\
\text { observed. }\end{array}$ & $2 \mathrm{~B}$ \\
\hline
\end{tabular}

\section{Interpretation}

As the only limestone midden described on this project, 41BR433 provides a critical gauge for comparing the sediments at sandstone and limestone constructed middens. One general pattern is clear, the deposits at 41BR433 are more fine-grained and more completely bioturbated than deposits at sandstone midden sites. Even though earthworm turbation was very visible at virtually all the sites with sandstone middens, the pedogenic processes were more developed at the limestone midden.

\section{$41 \mathrm{BR} 441$}

Site 41BR441 consists of a burned rock midden on the sloping surface of an alluvial fan above Lewis Creek. This is part of the same fan complex with 41BR474, but 41BR441 is positioned in a medial or proximal location on the fan. The surface of this landform slopes down towards Lewis Creek. Soils on the alluvial fan are mapped as Pedernales series and Callahan-Throck associations.

A single backhoe trench (Trench 4) was excavated into the southernmost burned rock midden parallel with the slope, and it extended upslope above the burned rock midden to expose more fully the lower deposits. Two profiles were described from Trench 4 at 41BR441 (Profiles 5 and 6).

Profile 6 was within the midden and will be described first. In Profile 6, three depositional units were observed (Table G-26). In the upper $52 \mathrm{~cm}$ was a black to dark gray sandy loam with abundant worm casts, common rootlets, and 50-60 percent clast supported burned rock. This is a typical burned rock midden deposit and it was divided into two zones (A1 and A2) based on color and burned rock distribution. The lower $12 \mathrm{~cm}$ consisted of a basal burned rock feature within the burned rock midden. The lower boundary is unconformable. Below this boundary is a buried, possibly truncated, A horizon consisting of brown sandy loam and a yellowish-brown sandy loam 2B horizon extending down to $91 \mathrm{~cm}$. A clear, smooth lower boundary separates this B horizon from a $3 \mathrm{~B}$ horizon consisting of brown clay loam with yellowish-red mottles.

Upslope from Profile 6, beyond the limits of the burned rock midden, was Profile 5 (Table G-27). The deposits reflect little anthropogenic influence. In the upper $49 \mathrm{~cm}$ were $\mathrm{A} 1$ and $\mathrm{A} 2$ horizons consisting of dark grayish-brown to brown sandy loams. These sat unconformably on a thick series of 2B1-2B3 horizons. These ranged from a dark yellowish-brown to grayish-brown loam to clay loam. These 2B horizons sit unconformably on a third geological unit weathered to a $3 \mathrm{~B}$ horizon. A high percentage of this $3 \mathrm{~B}$ horizon consists of soft carbonate bodies.

\section{Interpretation}

The A1 and A2 horizons in Profile 6 are within the burned rock midden and are stratigraphically above the deposits in Profile 5. The A1 and A2 horizons in Profile 5 can be correlated to the 2A horizon in Profile 6. The $21 \mathrm{~cm}$ thick 2B horizon in Profile 6 can be correlated to the $216 \mathrm{~cm}$ thick 2B1-2B3 horizons in Profile 5, and the 3B horizons 
Table G-26. Profile 6: Description for Trench 4 (within the midden near basal feature), 41BR441

\begin{tabular}{|l|l|l|l|}
\hline ZONE & DEPTH & DESCRIPTION & HORIZON \\
\hline 1 & $0-40$ & $\begin{array}{l}\text { Black (10YR2/1) sandy loam, abundant worm casts, common } \\
\text { rootlets, 50-60\% burned rock matrix and clast supported, } \\
\text { clear irregular lower boundary. }\end{array}$ & A1 \\
\hline 2 & $40-52$ & $\begin{array}{l}\text { Dark gray (10YR3/1) sandy loam, same as above, clear } \\
\text { irregular lower boundary. }\end{array}$ & A2 \\
\hline 3 & $52-70$ & $\begin{array}{l}\text { Brown (10YR4/3) sandy loam with weak medium subangular } \\
\text { blocky structure, less than 1\% CaCO } \text { filaments, few flint } \\
\text { flakes, few rootlets, medium root casts filled with dark } \\
\text { organic material, clear smooth lower boundary. }\end{array}$ & $2 \mathrm{~A}$ \\
\hline 4 & $70-91$ & $\begin{array}{l}\text { Yellowish-brown (10YR5/4) sandy loam with weak medium } \\
\text { subangular blocky structure, few roots and rare rootlets, 5\% } \\
\text { root casts, clear smooth lower boundary. }\end{array}$ & $2 \mathrm{~B}$ \\
\hline 5 & $91-120+$ & $\begin{array}{l}\text { Brown (10YR4/3) clay loam with fine medium angular blocky } \\
\text { structure, few worm casts, diffuse-fine weak yellowish-red } \\
\text { (5YR5/8) mottles, lower boundary not observed. }\end{array}$ & $3 \mathrm{~B}$ \\
\hline
\end{tabular}

Table G-27. Profile 5: Description for Trench 4 (outside of the midden), 41BR441

(far upslope and beyond distal end of burned rock midden at colluvial sandy wedge)

\begin{tabular}{|l|l|l|l|}
\hline ZONE & DEPTH & DESCRIPTION & HORIZON \\
\hline 1 & $0-27$ & $\begin{array}{l}\text { Dark grayish-brown (10YR4/2) structures sandy loam, } \\
\text { common rootlets, clear smooth lower boundary. }\end{array}$ & A1 \\
\hline 2 & $27-49$ & $\begin{array}{l}\text { Brown (10YR4/3) firm sandy loam, few worm burrows, } \\
\text { rootlets and roots. }\end{array}$ & A2 \\
\hline 3 & $49-64$ & $\begin{array}{l}\text { Dark yellowish-brown (10YR4/4) very firm loam with dark } \\
\text { grayish-brown (10YR3/2) and yellowish-red (5YR5/8) mottles, } \\
\text { few manganese nodules, few small sub rounded less than 1- } \\
\text { cm pebbles, clear smooth lower boundary. }\end{array}$ & 2 B1 \\
\hline 4 & $64-200$ & $\begin{array}{l}\text { Brown (10YR4/3) very firm clay loam with manganese } \\
\text { nodules and stains on well-developed ped faces, moderate } \\
\text { medium angular blocky structure, CaCO filaments less than } \\
\text { 1\%, few roots, clear smooth lower boundary. }\end{array}$ & 2 B2 \\
\hline 5 & $200-265$ & $\begin{array}{l}\text { Grayish-brown (2,5YR5/2) to Light olive brown (2.5YR5/3) } \\
\text { clay loam with medium moderate to strong angular blocky } \\
\text { structure, few 1-2\% CaCO3 nodules, abrupt smooth lower } \\
\text { boundary. }\end{array}$ & 2 B3 \\
\hline 6 & $265-300+$ & $\begin{array}{l}\text { Yellowish-brown }(10 Y R 5 / 6) \text { to olive brown (2.5YR5/3) silty } \\
\text { clay loam, 85\% CaCO3 soft bodies similar to lower deposit in } \\
\text { profile 1. }\end{array}$ & $3 \mathrm{~B}$ \\
\hline
\end{tabular}

in both profiles can be correlated. The thick $2 \mathrm{~B}$ horizons in Profile 5 become much thinner downslope and form a wedge of sediment that thickens towards the uplands. This suggests that these sediments are colluvial fan deposits. It is possible that slopewash eroded the top of this fan deposit, but no clear evidence of erosion was observed.

\section{$41 B R 474$}

41BR474 consisted of two, possibly three, burned rock middens on a flat, but slightly sloping distal tip of an alluvial fan above Lewis Creek. The surface of this landform gradually slopes down towards Lewis Creek. Across the creek was a 
low, recent terrace. Soils on the alluvial fan are mapped as Pedernales series and Frio soils are mapped on the recent terrace across the creek from the site. Pedernales soils are deep upland soils formed in thick beds of calcareous clayey and loamy material. Frio soils are deep loamy soils formed on calcareous alluvium in frequently flooded bottomlands.

At this site, two parallel rows of burned rock, combined are the size of a typical burned rock midden, suggest that a single midden had been bisected by a previously excavated trench or scraping. Three trenches were excavated at 41BR474. A single backhoe trench (Trench 1) was cut through each of the two rows of burned rock and into a 1-x-1-m unit excavated into the midden. Two profiles (Profiles 1 and 2) were described in this trench. Profile 1 was described on the edge of the burned rock midden, while Profile 2 was described in the 1-x-1-m unit excavated in the trenched or scraped portion of the midden. Trench 2 was dug into the low, recent terrace across Lewis Creek from the site, and Profile 3 describes those sediments. Trench 3 was cut through the second midden in the southern portion of 41BR474 and Profile 4 described sediments exposed by this trench.

Profile 1 extended to a depth of $250 \mathrm{~cm}$ and three depositional units were identified (Table G-28). The upper 20 $\mathrm{cm}$ consisted of a black loam with burned limestone clasts and common worm burrows. This is the edge of the midden and represents an anthropogenic A horizon. The midden sits on a $15 \mathrm{~cm}$ thick dark gray loam identified as an A2 horizon. The clear smooth-wavy lower boundary is believed to represent an unconformity. Below the A2 horizon is $62 \mathrm{~cm}$ of dark brown to brown clay loam. Clay content gradually increases down the profile and these sediments were divided into $2 \mathrm{~B}$ and $2 \mathrm{Bt}$ horizons. The $2 \mathrm{Bt}$ horizon had 1-5 percent calcium carbonate filaments. From $97 \mathrm{~cm}$ to $250 \mathrm{~cm}$ below the surface a third deposition unit was identified and divided into 3Bt1, 3Bt2, 3Bwt1, and 3Bwt2 horizons. These sediments consist of yellow-brown clay loams and contain significant amounts of calcium carbonate nodules (20-75\%) reflecting a much greater degree of weathering.

Sediments in Profile 2 were described to a depth of $85 \mathrm{~cm}$ (Table G-29). In the upper $26 \mathrm{~cm}$ of Profile 2, an anthropogenic A1 horizon was identified above an A2 horizon. The A1 horizon is a black silt loam and appears to contain a great proportion of ash. The A2 horizon is a yellow-brown clay loam. The A horizons sit unconformably on dark yellow brown to yellow brown clay loams and these are classified as $2 \mathrm{Bt} 1$ and $2 \mathrm{Bt} 2$ horizons.
Profile 3 describes $190 \mathrm{~cm}$ of alluvial sediments in Trench 2 (Table G-30). The upper $3 \mathrm{~cm}$ consists of an $\mathrm{O}$ horizon. This covered a dark gray loam identified as an A horizon between 3-27 cm. From 27-190 cm were a series of C horizons ranging from gravels supported by dark grayishbrown to olive brown loams to sandy layers to clast supported gravel layers. The absence of calcium carbonate suggests these sediments were fairly recent in age, and clearly distinct from sediments described in the other profiles at 41BR474.

Profile 4 describes $136 \mathrm{~cm}$ of sediments in Trench 3 (Table G-31). The upper $13 \mathrm{~cm}$ is a burned rock midden deposit (anthropogenic A horizon) consisting of a dark gray ashy silt loam with burned sandstone and limestone clasts. This sits on a very dark gray ashy silt loam classified as an A2 horizon. Between 21-105 $\mathrm{cm}$ below the surface are a series of B horizons (B1, B2, and B3) consisting of yellowishbrown to reddish-brown to yellowish-red silt loam to loam, but below $105 \mathrm{~cm}$ is a reddish-brown silt loam with abundant soft calcium carbonate nodules. This lower horizon is classified as a $2 \mathrm{~B}$ horizon and clearly represents a separate depositional unit.

\section{Interpretation}

The described profiles at 41BR474 indicate that the recent alluvial sediments consist of gravelly and sandy deposits that have weathered into the Frio soils with an $\mathrm{A}-\mathrm{C}$ profile. The site sits on a higher surface that consists of as many as three depositional units. The lowest unit (Zones 5-8 in Profile 1, Zones 3 and 4 in Profile 2, and Zone 6 in Profile 4 ) is a well-weathered clay loam to silt loam and represents the oldest observed alluvial fan sediments at the site. No artifacts or features were observed in this sedimentary unit. The second depositional unit (Zones 3 and 4 in Profile 1, and Zones 3-5 in Profile 4) consists of dark brown to yellowish-red clay loam to silt loams. These sediments do not demonstrate the degree of weathering observed in the oldest sediments, and they probably represent a second, later, phase of alluvial fan accumulation on the edge of the valley. Again, no artifacts were observed in this unit. The most recent unit at this site is represented by the anthropogenic accumulation of midden deposits in Zones 1-2 in Profile 1, Zone 1 in Profile 2, and Zone 1 in Profile 4. The degree of worm burrowing in midden and lower sediments is striking and clearly represents a level of microdisturbance not often noticed in burned rock midden sediment descriptions. 
Table G-28. Profile 1: Description for Trench 1 (on the midden edge), 41BR474

\begin{tabular}{|c|c|c|c|}
\hline $\mathrm{ZONE}$ & DEPTH & DESCRIPTION & HORIZON \\
\hline 1 & $0-20$ & $\begin{array}{l}\text { Black (10YR2.5/1) loam with medium weak subangular } \\
\text { blocky structure, common rootlets and insect burrows, few to } \\
\text { common burned and unburned sandstone clasts from } 1.5^{-7} \\
\text { cm (profile on edge of midden), abrupt irregular horizontal } \\
\text { lower boundary. }\end{array}$ & A1 \\
\hline 2 & 20-35 & $\begin{array}{l}\text { Dark gray (10YR3/1) loam with medium moderate } \\
\text { subangular blocky to prismatic structure, few subrounded 1-3 } \\
\text { cm sandstone pebbles, medium rootlets that decrease in } \\
\text { density with depth, occasional large roots, common worm } \\
\text { casts, clear smooth lower boundary. }\end{array}$ & A2 \\
\hline 3 & $35-65$ & $\begin{array}{l}\text { Dark brown (7.5YR3/2) clay loam with medium-to-fine } \\
\text { subangular to angular blocky structure, few rootlets, roots } \\
\text { and worm casts, rare } 1-3 \mathrm{~cm} \text { sandstone pebbles, clear smooth } \\
\text { lower boundary. }\end{array}$ & 2B \\
\hline 4 & $65-97$ & $\begin{array}{l}\text { Brown (10YR4/3) clay loam, fine to medium moderate } \\
\text { subangular blocky structure, few manganese coatings on ped } \\
\text { faces, } \mathrm{CaCO}_{3} \text { filaments and nodules increasing in size and } \\
\text { density down the profile to } 5 \% \text {, few rootlets and worm casts, } \\
\text { rare roots, clear smooth lower boundary. }\end{array}$ & $2 \mathrm{Bt}$ \\
\hline 5 & $97-104$ & $\begin{array}{l}\text { Yellowish-brown (10YR5/4) clay loam, with medium to coarse } \\
\text { crumb structure, common small ( } 0.5-1 \mathrm{~cm}) \text { subangular } \\
\text { gravels, } 20-25 \% \mathrm{CaCO}_{3} \text { nodules, abrupt smooth lower } \\
\text { boundary. }\end{array}$ & $3 \mathrm{Bt}$ \\
\hline 6 & $104-156$ & $\begin{array}{l}\text { Yellowish-brown (10YR5/4) clay loam, medium to coarse } \\
\text { crumb structure, common earthworms casts of very dark } \\
\text { grayish-brown (10YR3/2) loam, } 50-75 \% \mathrm{CaCO}_{3} \text { nodules and } \\
\text { soft bodies, gradual smooth lower boundary }\end{array}$ & 3Bt2 \\
\hline 7 & $156-218$ & $\begin{array}{l}\text { Yellowish-red (5YR5/7) sandy silt with rare black (10YR2/3) } \\
\text { root casts, } 25-30 \% \mathrm{CaCO}_{3} \text { nodules and soft bodies, gradual } \\
\text { smooth lower boundary. }\end{array}$ & $3 \mathrm{Bwt}$ \\
\hline 8 & $218-250+$ & $\begin{array}{l}\text { Yellowish-brown(10YR5/6) clay loam, } 15-20 \% \mathrm{CaCO}_{3} \text {, rare } 2-5 \\
\text { cm quartzite subrounded pebbles, lower boundary not } \\
\text { observed. }\end{array}$ & $3 \mathrm{~B} 2 \mathrm{wt}$ \\
\hline
\end{tabular}

Table G-29. Profile 2: Description for Trench 1 (near center of midden), 41BR474

\begin{tabular}{|c|c|c|c|}
\hline ZONE & DEPTH & DESCRIPTION & HORIZON \\
\hline 1 & $0-26$ & $\begin{array}{l}\text { Black (10YR2/1) silt loam with abundant ash, loose to } \\
\text { medium crumb structure, common rootlets and matrix } \\
\text { supported burned sandstone, common worm burrows, lower } \\
\text { boundary was abrupt, smooth irregular. }\end{array}$ & $\mathrm{A} 1$ \\
\hline 2 & $26-37$ & $\begin{array}{l}\text { Yellowish-brown (10YR5/4) clay loam. } 50-60 \% \text {, dark grayish- } \\
\text { brown medium to fine mottles concentrated on ped faces, } \\
\text { represents organic staining from overlying zones, medium } \\
\text { moderate subangular to angular blocky structure with } 1 \% \\
\mathrm{CaCO}_{3} \text { nodules, clear smooth lower boundary. }\end{array}$ & $\mathrm{A} 2$ \\
\hline 3 & $37-57$ & $\begin{array}{l}\text { Dark Yellowish-brown (10YR4/4) clay loam, } 15-20 \% \text { dark } \\
\text { organic staining on ped faces, less than } 1 \% \mathrm{CaCO}_{3} \text { nodules } \\
\text { and filaments, are roots and rootlets, clear smooth lower } \\
\text { boundary. }\end{array}$ & $2 \mathrm{Bt} 1$ \\
\hline 4 & $57-85+$ & $\begin{array}{l}\text { Yellowish-brown (10YR4.5/4) clay loam, fine to medium } \\
\text { angular blocky structure, } 10-15 \% \mathrm{CaCO}_{3} \text { medium nodules } \\
\text { and soft bodies increasing down profile. }\end{array}$ & $2 \mathrm{Bt} 2$ \\
\hline
\end{tabular}


Table G-30. Profile 3: Description for Trench 2, across the stream from 41BR474

(in low terrace across from steam)

\begin{tabular}{|l|l|l|l|}
\hline ZONE & DEPTH & DESCRIPTION & HORIZON \\
\hline 1 & $0-3$ & Organic. Leaves, twigs and rootlets. & O \\
\hline 2 & $3-27$ & $\begin{array}{l}\text { Dark gray (10YR3/2) loam, fine moderate subangular blocky } \\
\text { structure, common rootlets, roots, insect and worm burrows, } \\
\text { few snail shells, rare very small sandstone pebbles, abrupt } \\
\text { wavy lower boundary. }\end{array}$ & A \\
\hline 3 & $27-85$ & $\begin{array}{l}\text { Dark grayish-brown (10YR3/2) loam supported gravel, } \\
\text { common gravels 1-13 cm in diameter with average diameter } \\
\text { 4cm, few roots and rootlets, gravels vary from angular to } \\
\text { rounded most are subrounded, no imbrication, clear irregular } \\
\text { lower boundary. }\end{array}$ & C1 \\
\hline 4 & $85-133$ & $\begin{array}{l}\text { Olive brown (2.5YR4/4) loam supported gravel with 0.5-16 cm } \\
\text { average 3cm size, little to no sublayering, no imbrication, } \\
\text { clear irregular lower boundary. }\end{array}$ & C2 \\
\hline 5 & $133-190+$ & $\begin{array}{l}\text { Dark Yellowish-brown (10YR4/4) alternating coarse sandy } \\
\text { and gravely layers, clast supported gravel layer between 138- } \\
175 \text { cm with diameters between 0.5-10 cm with manganese } \\
\text { stains, between 175-183 cm was a dark yellowish-brown } \\
\text { (10YR4/4) silty sand. }\end{array}$ & C3 \\
\hline
\end{tabular}

Table G-31. Profile 4: Description for Trench 3 in midden at 41BR474 (at distal end of burned rock midden)

\begin{tabular}{|l|l|l|l|}
\hline ZONE & DEPTH & DESCRIPTION & HORIZON \\
\hline 1 & $0-13$ & $\begin{array}{l}\text { Dark gray (10YR3/1) ashy silt loam with burned sandstone } \\
\text { and limestone clasts supported by fine grain matrix, abrupt } \\
\text { irregular lower boundary. }\end{array}$ & A1 \\
\hline 2 & $13-21$ & $\begin{array}{l}\text { Very dark grayish-brown (10YR3/2) ashy silt loam, few small } \\
\text { 5cm burned rock, few flint flakes, matrix supported, charcoal } \\
\text { sample taken at 15 cm below burned rock, clear smooth lower } \\
\text { boundary. }\end{array}$ & A2 \\
\hline 3 & $21-33$ & $\begin{array}{l}\text { Yellowish-brown (10YR5/4) silt loam with weak fine } \\
\text { subangular blocky structure, common earth worm burrows } \\
\text { filled with dark grayish-brown (10YR3/2) casts, clear smooth } \\
\text { lower boundary. }\end{array}$ & B1 \\
\hline 4 & $33-74$ & $\begin{array}{l}\text { Reddish-brown (5YR4/4) silt loam with fine weak subangular } \\
\text { blocky structure, many ped faces and rootlet casts with } \\
\text { CaCO } \text { filaments, few small 1-1.5 cm subrounded to round } \\
\text { pebbles, clear smooth lower boundary. }\end{array}$ & Bw2 \\
\hline 5 & $74-105$ & $\begin{array}{l}\text { Yellowish-red (5YR4/6) loam with medium to moderate } \\
\text { subangular blocky structure, manganese flakes, no CaCO }, \\
\text { rare subrounded to rounded 2cm quartz and sandstone } \\
\text { pebbles, few worm casts, abrupt wavy lower boundary. }\end{array}$ & Bw3 \\
\hline 6 & $105-136+$ & $\begin{array}{l}\text { Reddish-brown (5YR4/4) silt loam with 75\% dispersed CaCO } 3 \\
\text { pale brown (10YR8/4) soft bodies. }\end{array}$ & 2 Bw \\
\hline
\end{tabular}




\section{$41 B R 480$}

41BR480 is in the Devils River floodplain and it has one midden on a low rise behind (southeast) a natural levee adjacent the river and below (northwest of) the valley wall. Three profiles were described at this site. The first two profiles (21 and 23, the number 22 was not used, inadvertently) were from the core of the midden and the third profile (24) was taken from a natural cutbank in the river to the north of the site.

Profile 21 was described from Unit 1 (Table G-32). The upper $2 \mathrm{~cm}$ is an $\mathrm{O}$ horizon. Between $2-41 \mathrm{~cm}$ are $\mathrm{A} 1$ and A2 horizons which are within the midden. These range from dark grayish-brown to dark gray sandy loams, and again show intense turbation from earthworms. The midden sediments sit unconformably on a dark grayish-brown loam with stream worn pebbles (2Bt2), and this grades down into a yellowish-red to dark reddish-brown clay loam (2Bt3).

The upper $50 \mathrm{~cm}$ of deposits in Profile 23 are similar to those in Zones 1-3 in Profile 21, however, Zone 4 in Profile 23 is a dark brown loam that appears to show more of the submidden soil profile than observed in Profile 21 (Table G-33). It is classified as a $2 \mathrm{Bt}$ horizon.
Profile 24 is in the right (south) bank of Devils River $50 \mathrm{~m}$ north of 41BR480. These sediments provide a $410 \mathrm{~cm}$ thick view into the Devils River floodplain. These sediments consist of alternating beds of sands, loams, and gravels (Table G-34). Zone 4 consists of an infilled channel deposit.

\section{Interpretation}

The midden at 41BR480, again, appears to have been constructed on the surface of the floodplain and accumulated above the alluvial sediments. The alluvial sediments suggest that the Devils River was actively aggrading and eroding with a reasonable amount of energy. The occupation at 41BR480 appears to have occurred after Zone 1 had accumulated. The age of these fluvial deposits is unknown.

\section{IBR492}

Four profiles were described at 41BR492. This site sits very near the escarpment base that forms the valley wall of Pecan Bayou and Lewis Creek. The surface slopes slightly to the northeast towards Lewis Creek. A single burned rock midden was recorded at this site. Profile 30 was recorded from Unit 2 within the burned rock midden's central depression. Profile 31 was recorded from Unit 5. This excavation unit is upslope

Table G-32. Profile 21: Description for Unit 1 (edge of north wall), 41BR480

\begin{tabular}{|l|l|l|l|}
\hline ZONE & DEPTH & DESCRIPTION & HORIZON \\
\hline 1 & $0-2$ & $\begin{array}{l}\text { Dark grayish-brown (10YR3/2) finely decomposed leaf litter, } \\
\text { rootlets and stems. Lower boundary was abrupt and wavy }\end{array}$ & O \\
\hline 2 & $2-8$ & $\begin{array}{l}\text { Dark grayish-brown (10YR3/2) slightly firm sandy loam with } \\
\text { weak medium to fine sub angular blocky structure, common } \\
\text { rootlets, common( 40-50\%) worm casts, few small up to 5cm } \\
\text { sandstone tabular and cobble burned and unburned } \\
\text { fragments, clear irregular lower boundary. }\end{array}$ & A1 \\
\hline 3 & $8-41$ & $\begin{array}{l}\text { Dark gray (10YR3/1) firm sandy loam, common to many } \\
\text { burned sandstone tabular and cobbles up to 13 cm, few } \\
\text { rootlets and insect burrows, common (50-60\%) worm burrows } \\
\text { and casts, smooth abrupt lower boundary slopes west. }\end{array}$ & A2 \\
\hline 4 & $41-51$ & $\begin{array}{l}\text { Dark grayish-brown (10YR3/2) loam with common (20\%) } \\
\text { small sandstone and quartzite sub rounded and angular } \\
\text { pebbles from 1-3mm, few root casts, common worm casts, } \\
\text { smooth abrupt lower boundary slopes west. }\end{array}$ & 2 Bt2 \\
\hline 5 & $51-54+$ & $\begin{array}{l}\text { Yellowish-red ( 5YR4/6) to Dark reddish-brown (5YR3/2) clay } \\
\text { loam, common 1-10mm sub rounded and angular sandstone } \\
\text { and chert pebbles (50-70\%), few rare large sub rounded } \\
\text { pebbles up to 5cm, few roots, lower boundary was not } \\
\text { observed. }\end{array}$ & 2 Bt3 \\
\hline
\end{tabular}


Table G-33. Profile 23: Description for Unit 3 (north wall), 41BR480

\begin{tabular}{|c|c|c|c|}
\hline ZONE & DEPTH & DESCRIPTION & HORIZON \\
\hline $1-3$ & $0-50$ & Similar to zone $1-3$ on profile 22 . & $\mathrm{O}-\mathrm{A} 2$ \\
\hline 4 & $50+$ & $\begin{array}{l}\text { Dark brown (10YR3/2) loam with moderate medium-fine } \\
\text { subangular blocky structure, common worm burrows and } \\
\text { casts, few } \mathrm{CaCO}_{3} \text { filaments on rootlet pores, few angular } \\
\text { sandstone and chert clasts ranging from yellowish-red (5yr } \\
\text { 4/6) with dark reddish-brown (5YR3/2) nodules. }\end{array}$ & $2 \mathrm{Bt}$ \\
\hline
\end{tabular}

Table G-34. Profile 24: Description for Cutbank north of 41BR480

( in cutbank on south side of gully, weathered alluvial terrace)

\begin{tabular}{|c|c|c|c|}
\hline ZONE & DEPTH & DESCRIPTION & HORIZON \\
\hline 1 & $0-15$ & $\begin{array}{l}\text { Pale brown (10YR6/3) fine sand with large and small burned } \\
\text { and unburned sandstone and chert clasts that almost form } \\
\text { pavement (possibly an eroded midden). }\end{array}$ & A \\
\hline 2 & $15-210$ & $\begin{array}{l}\text { Reddish-brown (5YR4/4) loam, common matrix supported } \\
\text { subangular to subrounded pebbles and gravels, clear smooth } \\
\text { lower boundary. }\end{array}$ & $\mathrm{B}$ \\
\hline 3 & $\begin{array}{l}210^{-} \\
280 / 300\end{array}$ & $\begin{array}{l}\text { Channel filled with gravels and pebbles that are sub rounded } \\
\text { and well rounded eroded into a yellowish-red (5YR5/6) fine } \\
\text { sand, slightly firm cemented with } 1 \% \mathrm{CaCO}_{3} \text { filaments that } \\
\text { extend down to } 300 \mathrm{~cm} \text {. }\end{array}$ & C1 \\
\hline 4 & $\begin{array}{l}280 / \\
300-370\end{array}$ & Channel fill. Sub rounded to rounded pebbles. & $\mathrm{C} 2$ \\
\hline 5 & $370-410$ & $\begin{array}{l}\text { Reddish-yellow (5YR5/6) slightly firm medium sand, insect } \\
\text { and worm burrows, some fine angular gravels at } 410 \text { sits on a } \\
\mathrm{CaCO}_{3} \text { cemented (pedocalcrate) gravel deposit. }\end{array}$ & $2 \mathrm{~B}$ \\
\hline
\end{tabular}

and west of the burned rock midden. Profile 32 was documented from Unit 4 which is downslope and northeast of the midden. Profile 33 was collected from a backhoe trench excavated near Unit 4.

Sediments in Profile 30 were divided into five zones (Table G-35). The upper $1 \mathrm{~cm}$ is an $\mathrm{O}$ horizon. The midden deposits were divided into three A horizons. These sediments grade from a black to a very dark gray to a dark gray ashy fine sandy silt between $1-125 / 135 \mathrm{~cm}$. The middle midden zone, Zone 3, has a great deal of calcium carbonate filaments (up to $5 \%$ ), and all the midden deposits were severely turbated by earthworms. Between 125/135-145+ cm is a yellowishbrown loam.

Sediments in Unit 5 (Profile 31) are very different (Table G-36). An O horizon was documented in the first centimeter, while between 1-20 cm is a grayish-brown sandy loam A horizon. This sits unconformably on a brown sandy loam 2B horizon that extends below $35 \mathrm{~cm}$.
The sediments in Profile 32, taken in Unit 4 downslope from the midden, are different still (Table G-37). The upper $8 \mathrm{~cm}$ consist of a light brownish-gray silt. Below this is a dark grayish-brown loam between $8-30 \mathrm{~cm}$. From $30-50 \mathrm{~cm}$ is a very dark grayish-brown loam that grades to a dark grayishbrown loam that extends to at least $75 \mathrm{~cm}$. These sediments are alluvial sediments from Lewis Creek.

Sediments recorded in Profile 40 are very similar to those in Profile 32, were recorded to depth of $140 \mathrm{~cm}$, and record a series of $\mathrm{A}$ and $\mathrm{B}$ horizons formed in alluvial sediments (Table G-38).

\section{Interpretation}

The sediments at 41BR492 show that the midden sediments accumulated at the intersection of an aggrading floodplain and colluvial fan. The deposits upslope of the midden are colluvial fan deposits and downslope the sediments were deposited by fluvial processes. Nevertheless, most of the sediments in the midden are anthropogenic in origin. 
Table G-35. Profile 30: Description for Unit 2, 41BR492

\begin{tabular}{|c|c|c|c|}
\hline ZONE & DEPTH & DESCRIPTION & HORIZON \\
\hline 1 & $0-1$ & $\begin{array}{l}\text { Grass stalks, leaves, rootlets, weed stalks, abrupt smooth } \\
\text { lower boundary. }\end{array}$ & $\mathrm{O}$ \\
\hline 2 & $1-51$ & $\begin{array}{l}\text { Black (N 2.5) ashy fine sand silt, common sandstone } \\
\text { fragments mostly tabular up to } 17 \mathrm{~cm} \text { but most were } 1-5 \mathrm{~cm} \text {, } \\
\text { common earth worm casts } 50-70 \% \text {, common rootlets, few roots, } \\
\text { larger clasts towards the bottom, clear wavy lower boundary. }\end{array}$ & A1 \\
\hline 3 & $51-92$ & $\begin{array}{l}\text { Very dark gray (10YR3/1) ashy fine sand and silt, abundant } \\
\mathrm{CaCO}_{3} \text { filaments interlocking cells } 5 \% \text { (most } \mathrm{CaCO}_{3} \text { seen in a } \\
\text { midden), } \mathrm{CaCO}_{3} \text { film on ped faces adjacent to rock, abundant } \\
\text { worm casts } 70-80 \% \text { (more than above), common sandstone } \\
\text { tabular clasts up to } 18 \mathrm{~cm} \text {, few roots and rootlets, clear } \\
\text { irregular lower boundary. }\end{array}$ & $\mathrm{A} 2$ \\
\hline 4 & $\begin{array}{l}92^{-} \\
125 / 135\end{array}$ & $\begin{array}{l}\text { Dark gray (10YR4/1) ashy fine sand silt, few ( less than 1\%) } \\
\text { CaCO } 3 \text { filaments on root pores, } 3 \text { or } 4 \text { mussel shell fragments } \\
\text { in lower portion of zone, abrupt irregular lower boundary. }\end{array}$ & A3 \\
\hline 5 & $\begin{array}{l}125 / 135^{-} \\
145^{+}\end{array}$ & $\begin{array}{l}\text { Yellowish-brown (10YR5/6) loam, common earth worm } \\
\text { burrows with casts, common } \mathrm{CaCO}_{3} \text { filaments on root pores } \\
\text { (less than } 10 \% \text { ), lower boundary was not observed. }\end{array}$ & $2 \mathrm{~B}$ \\
\hline
\end{tabular}

Table G-36. Profile 31: Description for Unit 5, 41BR492

(Upslope adjacent to midden. Lower deposits in Unit 5 appear similar to lower deposits in Units 1 and 2.)

\begin{tabular}{|l|l|l|l|}
\hline ZONE & DEPTH & DESCRIPTION & HORIZON \\
\hline 1 & $0-1$ & $\begin{array}{l}\text { Grass stalks, leaf fragments, twigs, small amount of sand, } \\
\text { abrupt smooth-wavy lower boundary. }\end{array}$ & O \\
\hline 2 & $1-20$ & $\begin{array}{l}\text { Grayish-brown (10YR5/2) slightly firm sandy loam with coarse } \\
\text { subangular blocky structure, common insect burrows, few } \\
\text { pebbles and roots, abrupt smooth lower boundary. }\end{array}$ & A \\
\hline 3 & $20-35+$ & $\begin{array}{l}\text { Brown (7.5YR4/4) firm sandy loam with medium moderate } \\
\text { subangular to angular blocky structure, common insect } \\
\text { burrows with dark casts, lower boundary not observed. }\end{array}$ & $2 \mathrm{~B}$ \\
\hline
\end{tabular}

Table G-37. Profile 32: Description for Unit 4, 41BR492

(Unit 4 is below midden in fine-grain alluvial deposit. Zone 2 in Unit 5 may correlate to Unit 4.)

\begin{tabular}{|l|l|l|l|}
\hline ZONE & DEPTH & DESCRIPTION & HORIZON \\
\hline 1 & $0-8$ & $\begin{array}{l}\text { Light brown gray (10YR6/2) silt with medium weak } \\
\text { subangular blocky structure, clear smooth lower boundary. }\end{array}$ & A \\
\hline 2 & $8-30$ & $\begin{array}{l}\text { Dark grayish-brown (10YR4/2) loam with weak fine to } \\
\text { medium subangular blocky, gradual smooth lower boundary. }\end{array}$ & 2 A1 \\
\hline 3 & $30-50$ & $\begin{array}{l}\text { Very dark grayish-brown (10YR3/2) loam with moderate fine } \\
\text { to medium subangular blocky structure, gradual smooth lower } \\
\text { boundary. }\end{array}$ & 2 A2 \\
\hline 4 & $50-75+$ & $\begin{array}{l}\text { Dark grayish-brown (10YR4/3) loam with fine to medium } \\
\text { moderate subangular blocky structure, few insect and worm } \\
\text { burrows filled with pale brown (10YR8/3) sand, few small } \\
\text { (5mm) sandstone pebbles, some (20\%) insect and worm casts, } \\
\text { lower boundary not observed. }\end{array}$ & 2 A3 \\
\hline
\end{tabular}


Table G-38. Profile 40: Description for Backhoe Trench adjacent to Unit 4 (on south side), 41BR492

\begin{tabular}{|c|c|c|c|}
\hline ZONE & DEPTH & DESCRIPTION & HORIZON \\
\hline 1 & $0-1$ & Leaves, twigs, grass stalks. & $\mathrm{O}$ \\
\hline 2 & $1-9$ & $\begin{array}{l}\text { Light brownish-gray (10YR6/2) firm silt loam, few small } \\
\text { subrounded sandstone clasts up to } 1 \mathrm{~cm} \text {, clear smooth lower } \\
\text { boundary. }\end{array}$ & A \\
\hline 3 & $9-23$ & $\begin{array}{l}\text { Very dark grayish-brown (10YR3/2) silt loam with fine } \\
\text { subangular blocky weak structure, 10-20\% earth worm casts } \\
\text { and burrow, few insect burrows, few (less than } 1 \% \text { ) } \mathrm{CaCO}_{3} \\
\text { filaments observed between } 17-23 \mathrm{~cm} \text {, clear smooth lower } \\
\text { boundary. }\end{array}$ & $2 \mathrm{~A} 1$ \\
\hline 4 & $23-40$ & $\begin{array}{l}\text { Very dark gray (10YR3/2) firm loam with weak medium sub } \\
\text { angular blocky structure, very many rootlet pores, few }\left(10^{-}\right. \\
15 \% \text { ) earth worm casts, few small (much less than } 1 \mathrm{~cm}) \\
\text { sandstone clasts, gradual smooth lower boundary. }\end{array}$ & $2 \mathrm{~A} 2$ \\
\hline 5 & $40-66$ & $\begin{array}{l}\text { Very dark gray (10YR3/1) very firm loam with medium } \\
\text { moderate, with easily recognizable ped faces, blocky structure, } \\
\text { chert flake observed at } 53 \mathrm{~cm} \text {, gradual smooth lower } \\
\text { boundary. }\end{array}$ & $2 \mathrm{~A} 3$ \\
\hline 6 & $66-82$ & $\begin{array}{l}\text { Very dark gray (10YR3/1) same as above except } \mathrm{CaCO}_{3} \\
\text { filaments and films on ped faces, clear smooth lower } \\
\text { boundary. }\end{array}$ & $2 \mathrm{~A} 4$ \\
\hline 7 & $82-95$ & $\begin{array}{l}\text { Brown (10YR5/3) to dark yellowish-brown (10YR4/6) very firm } \\
\text { loam with moderate coarse subangular blocky structure, } \\
\text { common } \mathrm{CaCO}_{3} \text { films and small nodules, thin clay films on ped } \\
\text { faces, few } 1 \% \text { worm casts and burrows, clear smooth lower } \\
\text { boundary. }\end{array}$ & $2 \mathrm{~B} 1$ \\
\hline 8 & $95-140$ & $\begin{array}{l}\text { Dark yellowish-brown (10YR4/4) loam with medium moderate } \\
\text { subangular blocky structure, common ( } 5 \%) \mathrm{CaCO}_{3} \text { soft bodies } \\
\text { up to } 1 \mathrm{~cm} \text {, few } 1-2 \% \text { worm casts, dark staining on ped faces } \\
\text { dark grayish-brown (10YR4/2) clay films on ped faces, lower } \\
\text { boundary was not observed. }\end{array}$ & $2 \mathrm{~B} 2$ \\
\hline
\end{tabular}

\section{Discussion}

There are a number of patterns that can be derived from the geological study of the sites at Camp Bowie and these will be presented here. First, the base of escarpments seem to be favored for midden construction. There may be many reasons for this but the toeslopes of escarpments are near rock (escarpment), fuel (everywhere), and water (floodplains). Second, no middens were observed to be buried by significant colluvial or alluvial deposits. This could be a reflection of their age, but it could also be a function of their intended placement in the landscape. Third, sediments in alluvial/colluvial fans strongly suggest that these fans have accumulated at different times and some of these fans appear to be quite old-perhaps Pleistocene in age. No previously reported data could be found on the age of these fans. Fourth, a number of middens were constructed on surfaces and in locations that suggest that sediment, in addition to rock, was being transported for the construction and use of these middens. This helps support the midden formation models of Leach and Bousman (2001[1998]). Fifth, in some middens the presence of calcium carbonate enriched soil horizons indicates multiple uses of single middens and different periods of use in different middens on the same site. Sixth, all middens had evidence of extensive turbation, especially by earthworms. This was extremely surprising and observations of the degree of turbation was allowed because of the excellent preservation of the sandstone middens. This preservation also was reflected in the abundance of well-preserved organic plant materials in the sandstone middens. Limestone middens in west-central and especially east-central Texas never contain such wellpreserved plant materials and it seems clear that the best plant records for midden activities will come from sandstone middens, at least in this portion of the state. Finally, it is obvious that sites 41BR441 and 41BR474 have been disturbed by recent activities. 


\section{References Cited}

Barnes, V. E.

1967 Geologic Atlas of Texas, Brownwood Sheet. Bureau of Economic Geology, The University of Texas, Austin.

Clower, D. F.

1980 Soil Survey of Brown and Mills County, Texas. United States Department of Agriculture, Soil Conservation Service and the Texas Agricultural Experimental Station.

Leach, J. D., and C. B. Bousman

2001[1998] Chapter 7: Cultural and Secondary Formation Process: On the Dynamic Accumulation of Burned Rock Middens. In Test Excavations at the Culebra Creek Site, 41BX126, San Antonio, Texas, edited by D. L. Nickels, C. B. Bousman, J. D. Leach, and D. A. Cargill, pp. 119-145. Archaeological Survey Report, No. 265, Center for Archaeological Research The University of Texas at San Antonio and Archeological Studies, Report 3, Environmental Affairs Division, Texas Department of Transportation, Austin. 



\section{Appendix $\mathbf{H}$}

\section{Magnetic Sediment Susceptibility Testing}




\title{
Appendix H: Magnetic Sediment Susceptibility Testing
}

\author{
Raymond P. Mauldin
}

The magnetic susceptibility (MS) of a given sediment sample can be thought of as a measure of how easily that sample can be magnetized (Dearing 1999; Gose and Nickels 2001[1998]). At low magnetic field strengths, this measure is primarily related to the concentration and grain size of ferro and ferromagnetic minerals in the sample (Gose and Nickels 2001[1998]). A number of processes can result in an increase in MS values in a sediment sample. Of these processes, those that are of concern here are related to an increase in the organic constitutes or changes in the mineralogy of sediments in a given sample (see Collins et al. 1994; McClean and Kean 1993; Singer and Fine 1989). Sediments with higher organic content tend to have higher magnetic susceptibility values, probably as a result of the production of maghemite, an iron oxide, during organic decay (Reynolds and King 1995). Pedogenic processes, such as soil formation and weathering, can result in the concentration of organic material, as well as alterations in the mineralogy of a given zone. These processes can significantly impact susceptibility readings. Cultural processes, such as the concentration of ash, charcoal, and refuse, would also produce higher MS readings. A measure of the magnetic susceptibility of a sediment sample, then, may provide information on both the presence of surfaces, as well as a measure of the concentration of cultural activity upon those surfaces.

\section{Collection Procedures and Laboratory Methods}

A variety of samples were collected during this project. Here, we report on the 25 samples from 41BR492 used in Chapter 8 in volume 1 of this report. In addition, we use 279 samples from $41 B R 473$ as a test of the utility of the method. The samples reported from 41BR492 were collected from Unit 3. They were collected at 5 -cm intervals from the center of this 1-x-1-m excavation unit. These samples were placed in plastic bags, and stored in the laboratory at CAR until analysis.

Sediment samples were air dried on a non-metal surface. After drying, it was sometimes necessary to grind the samples into a uniform grain size using a ceramic mortar and pestle. This was done to standardize particle size and make the material both easier to handle and pack into sample containers. After each sample was prepared, the mortar and pestle were washed with tap water and wiped dry with a paper towel to avoid cross-sample contamination. The ground sample was then poured into a sample container consisting of a plastic cube with external dimensions of 2.54 $x 2.54 \times 1.94 \mathrm{~cm}$. The cubes have an average weight of 4.83 grams. The sediment filled cube was then weighed, and the weight of the sample calculated by subtracting the empty cube weight. This was done to correct for differences in mass. Assuming that sample volume and material is constant, larger samples should have higher susceptibility values simply as a function of greater mass.

The cube was then placed into a MS2B Dual Frequency Sensor that, in conjunction with a MS2 Magnetic Susceptibility Meter, provided a measure of the magnetic susceptibility of the sample (see Dearing 1999). For each cube, a single reading was taken using the SI (standard international) scale. The value, referred to as volume specific susceptibility and noted with the symbol Ko (Kappa), is recorded on a scale of $10^{-5}$, though there are no units associated with the value. That is, the value is dimensionless (Dearing 1999).

In order to correct for differences in sample weight, and provide units to the value $K_{\text {, }}$, the mass specific susceptibility value (X) was calculated using the formula

$$
X=\left(K_{0} / p\right)
$$

where $\mathrm{p}$ is the sample bulk density expressed in $\mathrm{kg} \mathrm{m}^{-3}$. The bulk density is determined by dividing the sample mass by volume. However, as all samples were measured in identical cubes, and all cubes were full, the sample volume is assumed to be constant. Only the mass of the sample varied. Mass specific susceptibility can be determined by

$$
\mathrm{X}=\mathrm{K} * \text { calibrated mass/ sample mass }
$$

where sample mass is determined by subtracting the cube weight from the total sample weight (Dearing 1999). Calibrated mass is assumed to be 10 grams.

While the resulting values now have both a scale and associated units, the critical element for the current discussion is related to relative differences between $\mathrm{X}$ sample 
values within a given profile or site, rather than absolute differences. That is, the principal interest is in rapid changes in the mass specific susceptibility values along a profile. This change may signal either a buried surface and/or cultural activity at that location. Comparisons of absolute values between samples from different areas, especially when the parent material of the soils is different, are of limited utility given our current goals.

This can be seen in Table H-1, which lists a variety of examples of mass specific susceptibility values for several different materials. In all cases, the analysis was performed following the procedures outlined previously. Note that the values differ widely, from a low of -1.47 for tap water, to a high of 97.62 for sediments collected from a burned rock midden. Samples 5 and 6 are on two different clays from the same general setting, far northern Lamar County in north
Texas. The mass specific susceptibility is different for these samples, probably as a function of different frequencies of trace elements that, though small in absolute quantity, can dramatically impact the susceptibility values.

The potential impacts of cultural processes on susceptibility values can be seen by considering a data set collected from site 41BR473. A total of 279 sediment susceptibility samples was collected from each $10-\mathrm{cm}$ level of over 50 shovel tests placed at this site. In all cases, the analytical procedures followed those outlined previously. Table H-2 presents summary data on all 279 cases, along with susceptibility scores for those settings that had fire-cracked rock (FCR) or chipped stone present. If cultural inputs result in higher susceptibility values, then it should be the case that significantly higher susceptibility values will be present in levels that have cultural material.

Table H-1. Magnetic Sediment Susceptibility Data for a Variety of Substances

\begin{tabular}{|l|c|c|c|c|c|c|c|}
\hline Sample Type & $\begin{array}{c}\text { Total } \\
\text { Wt. (gr.) }\end{array}$ & $\begin{array}{c}\text { Sample } \\
\text { Wt. (gr.) }\end{array}$ & $\begin{array}{c}\text { Reading } \\
\mathbf{1}(\mathbf{k})\end{array}$ & $\begin{array}{c}\text { Reading } \\
\mathbf{2}(\mathbf{k})\end{array}$ & $\begin{array}{c}\text { Reading } \\
\mathbf{3}(\mathbf{k})\end{array}$ & $\begin{array}{c}\text { Average } \\
\text { K }\end{array}$ & $\begin{array}{c}\text { Corrected } \\
\text { Mass (X) }\end{array}$ \\
\hline $\begin{array}{l}\text { 1) Sandy sediment } \\
\text { with organics }\end{array}$ & 13.7 & 8.85 & 27.9 & 28 & 28.1 & 28.00 & 31.64 \\
\hline $\begin{array}{l}\text { 2) Modern } \\
\text { mesquite charcoal } \\
\text { and sediment }\end{array}$ & 9.4 & 4.55 & 10.7 & 10.8 & 10.7 & 10.73 & 23.59 \\
\hline $\begin{array}{l}\text { 3) Modern oak } \\
\text { wood ash }\end{array}$ & 7.5 & 2.65 & 16.1 & 16.2 & 16.2 & 16.17 & 61.01 \\
\hline $\begin{array}{l}\text { 4) Sediment from } \\
\text { burned rock } \\
\text { midden }\end{array}$ & 11.3 & 6.45 & 62.9 & 63 & 63 & 62.97 & 97.62 \\
\hline $\begin{array}{l}\text { 5) Grey clay- no } \\
\text { human occupation }\end{array}$ & 12.6 & 7.75 & 10.4 & 10.3 & 10.4 & 10.37 & 13.38 \\
\hline $\begin{array}{l}\text { 6) Red clay-no } \\
\text { human occupation }\end{array}$ & 10.8 & 5.95 & 11.9 & 12 & 12 & 11.97 & 20.11 \\
\hline 7) Sandstone & 14.7 & 9.85 & 6.9 & 7 & 7.1 & 7.00 & 7.11 \\
\hline $\begin{array}{l}\text { 8) Limestone } \\
\text { 9) Tap water }\end{array}$ & 12.7 & 7.85 & -0.5 & -0.5 & -0.5 & -0.50 & -0.64 \\
\hline
\end{tabular}

Table H-2. Presence/absence of Cultural Material and Mass Specific Sediment Susceptibility Scores for Shovel Tests at 41BR473

\begin{tabular}{|l|c|c|c|c|c|}
\hline & All Cases & $\begin{array}{c}\text { FCR } \\
\text { Present }\end{array}$ & $\begin{array}{c}\text { FCR } \\
\text { Absent }\end{array}$ & $\begin{array}{c}\text { Chipped Stone } \\
\text { Present }\end{array}$ & $\begin{array}{c}\text { Chipped Stone } \\
\text { Absent }\end{array}$ \\
\hline $\begin{array}{l}\text { Number } \\
\text { of Samples }\end{array}$ & 279 & 84 & 195 & 38 & 241 \\
\hline Mean Value & 48.3 & 56.9 & 44.6 & 55.2 & 47.2 \\
\hline $\begin{array}{l}\text { Standard } \\
\text { Deviation }\end{array}$ & 17.2 & 17.7 & 15.6 & 16.1 & 17.1 \\
\hline
\end{tabular}


An examination of Table $\mathrm{H}-2$ will demonstrate that this is indeed the case. Levels that have FCR present do have higher scores relative to those that lack FCR. Similarly, those levels that have chipped stone present have a higher average mass specific susceptibility score relative to those that lack chipped stone. As the distribution is approximately normal, a t-test was used to test the overall significance of these differences. In both the FCR and chipped stone comparisons, the test confirms that those levels with cultural material have significantly higher scores than those without cultural material (FCR t-statistic $=5.804, \mathrm{df}=277, \mathrm{p}<.001$; chipped stone $\mathrm{t}$-statistic $=2.674, \mathrm{df}=277, \mathrm{p}=.008$ ). Our preliminary investigations, then, coupled with the previous work, clearly suggest that an analysis of the magnetic susceptibility of sediment can provide additional information on both the presence of buried surfaces, as well as the impact of cultural material on those surfaces.

\section{Summary}

Table H-3 presents the results of the susceptibility analysis of the 25 samples from 41BR492. Also included are the standardized values used in Chapter 8. An examination of the data will demonstrate that most of the corrected values range over 100 , with considerable variability between several of the cases. As discussed in Chapter 8, the variability in the values is substantial, and clearly suggests that a variety of surfaces may be present in this profile.

Table H-3. Sediment Susceptibility Data for 41BR492, Unit 3

\begin{tabular}{|c|c|c|c|c|c|}
\hline $\begin{array}{l}\text { Depth below } \\
\text { surface }(\mathrm{cm}) \text {. }\end{array}$ & $\begin{array}{c}\text { Total } \\
\text { Weight (gr.) }\end{array}$ & $\begin{array}{c}\text { Adjusted } \\
\text { Weight }\end{array}$ & $\begin{array}{c}\text { Reading } \\
(\mathrm{K})\end{array}$ & $\begin{array}{l}\text { Corrected } \\
\text { Value }(\mathbf{X})\end{array}$ & $\begin{array}{c}\text { Standardized } \\
\text { Corrected } \\
\text { Value } \\
\end{array}$ \\
\hline 2.50 & 10.70 & 5.87 & 82.50 & 140.55 & 0.14721 \\
\hline 7.50 & 11.30 & 6.47 & 97.20 & 150.23 & 0.49649 \\
\hline 12.50 & 11.80 & 6.97 & 106.50 & 152.80 & 0.58901 \\
\hline 17.50 & 11.00 & 6.17 & 109.00 & 176.66 & 1.44948 \\
\hline 22.50 & 11.00 & 6.17 & 113.90 & 184.60 & 1.73584 \\
\hline 27.50 & 11.90 & 7.07 & 117.30 & 165.91 & 1.06190 \\
\hline 32.50 & 11.80 & 6.97 & 117.80 & 169.01 & 1.17359 \\
\hline 37.50 & 11.40 & 6.57 & 98.33 & 149.67 & 0.47605 \\
\hline 42.50 & 11.10 & 6.27 & 86.30 & 137.64 & 0.04244 \\
\hline 47.50 & 11.60 & 6.77 & 98.00 & 144.76 & 0.29905 \\
\hline 52.50 & 11.60 & 6.77 & 81.87 & 120.93 & -0.56006 \\
\hline 57.50 & 11.90 & 7.07 & 83.30 & 117.82 & -0.67215 \\
\hline 62.50 & 11.70 & 6.87 & 77.23 & 112.42 & -0.86707 \\
\hline 67.50 & 11.90 & 7.07 & 76.57 & 108.30 & -1.01539 \\
\hline 72.50 & 11.70 & 6.87 & 119.67 & 174.19 & 1.36045 \\
\hline 77.50 & 11.80 & 6.97 & 99.13 & 142.22 & 0.20773 \\
\hline 82.50 & 12.30 & 7.47 & 92.17 & 123.39 & -0.47149 \\
\hline 87.50 & 11.30 & 6.47 & 105.50 & 163.06 & 0.95906 \\
\hline 92.50 & 12.20 & 7.37 & 104.17 & 141.34 & 0.17598 \\
\hline 97.50 & 11.40 & 6.57 & 85.30 & 129.83 & -0.23907 \\
\hline 102.50 & 11.40 & 6.57 & 74.50 & 113.39 & -0.83180 \\
\hline 107.50 & 12.20 & 7.37 & 87.53 & 118.77 & -0.63813 \\
\hline 112.50 & 12.00 & 7.17 & 76.83 & 107.15 & -1.05678 \\
\hline 117.50 & 11.90 & 7.07 & 66.00 & 93.35 & -1.55448 \\
\hline 122.50 & 11.50 & 6.67 & 49.07 & 73.57 & -2.26785 \\
\hline
\end{tabular}




\section{References Cited}

Collins, M. B., W. A. Gose, and S. Shaw

1994 Preliminary Geomorphological Findings at Dust and Nearby Caves. Journal of Alabama Archaeology 40:35-56.

Dearing, J.

1999 Environmental Magnetic Susceptibility. Chi publishing, Kenilworth, England.

Gose, W. A., and D. L. Nickels

2001 Archaeomagnetic and Magnetic Susceptibility Analyses. In Test Excavations at the Culebra Creek Site, 41BX126, Bexar County, Texas. D. L. Nickels, C. B. Bousman, J. D. Leach, and D. A. Cargill, pp. 204-214. Archaeological Survey Report, No. 265, Center for Archaeological Research, The University of Texas at San Antonio. Archeology Studies Program, Report 3, Environmental Affairs Division, Texas Department of Transportation, Austin.

McClean, R. G., and W. F. Kean

1993 Contributions of Wood Ash Magnetism to Archeomagnetic Properties of Fire Pits and Hearths. Earth and Planetary Science Letters 119:387-394.

Reynolds, R. L., and J. W. King

1995 Magnetic Records of Climate Change. U.S. National Report to I.U.G.G., 1991-1994. American Geophysical Union. $<$ http://www.agu.ong/revgeophys/reyno100/reyno100.html > Accessed April 2001.

Singer, M. J., and P. Fine

1989 Pedogenic Factors Affecting Magnetic Susceptibility of Northern California Soils. Soil Science of America Journal 53:1119-1127. 



\section{Appendix I}

\section{Description of Human Remains}




\title{
Appendix I: Description of Human Remains
}

\author{
Jeffrey R. Francis
}

On March 30, 2000, human skeletal remains were exposed during archaeological testing of site 41BR253 located on Camp Bowie, Brown County, Texas. The remains were located approximately $45 \mathrm{~cm}$ below the ground surface, and were protruding from the west wall of Test Units 4 and 5 . Once the bone was encountered, all work within the excavation area stopped, and all unscreened dirt was placed in plastic bags and left in the trench. Dr. Raymond Mauldin of the Center for Archaeological Research contacted Dr. Alan Wormser of the Texas Army National Guard. After that consultation, Lt. Mike McCoy of the Criminal Investigation Division of the Brown County Sheriff's Department inspected the remains.

After that inspection, and in consultation with the Texas Army National Guard, Mr. Jeff Francis, CAR staff osteologist, went to the site to describe the remains in detail. That description was conducted on March 31 and April 1, 2000. The remains represented the lower jaw, right elbow, pelvic area, and upper and lower legs of at least one individual in a flexed burial position. Specifically, the exposed elements consisted of the mandible with three intact teeth, the right elbow joint, the left and right innominates (pelvic bones), the sacrum, the left and right proximal femora (upper thigh), and the left and right distal tibiae (lower legs). The mandible, along with the left innominate and sacrum, were completely exposed, the right innominate was partially exposed, and only about 5 to $10 \mathrm{~cm}$ of the longbones were exposed. The rest of these elements remained buried in the soil and rock matrix. The exposed remains were examined and measured in situ.

The preliminary findings suggest that these remains appear to represent a young adult (25-49 years) female. The distribution of the remains suggests this is a flexed primary burial with the individual lying on her left side. There were small periosteal lesions on the buccal aspect of the mandible around the first and third molars. There were no squatting facets on the distal tibiae.

However, these findings are not conclusive. Several questions suggest that alternative conclusions may be possible. For example, the amount of wear on the teeth originally suggested that this was an older individual $(>30$ years), but the post-cranial remains suggest a younger individual ( $<25$ years). While the femora and pelvic bones are in anatomical position, the other elements may not be. The location of the mandible was inconsistent with a tightly flexed burial but could be appropriate for semi-flexed, however, the distance from the pelvic bones seems too great to be in natural position. Furthermore, there were no foot bones or vertebrae found. The lumbar vertebrae (lower back) should have been contiguous with the sacrum even in a tightly flexed burial. The bones of the foot could have been scavenged by rodents or lost during a re-interment. In addition, there was a rib fragment found (after the author left the site) several centimeters above the pelvic area. This is also out of natural position. These unanswered questions suggest 1) post-mortem settling of the remains, 2) a secondary interment, or 3) more than one individual. Given the amount of material exposed, it is impossible to determine which of these three alternatives is correct.

Note that no additional disturbance of the remains occurred during the description. No artifacts were associated with the remains. All described material, along with all unscreened sediment, was returned to the approximate location of the original discovery. No material was removed from the immediate area, and all material was left at the site. 
Appendix J

Diagnostic Artifacts from Burned Rock Middens in 13 Counties in Texas 


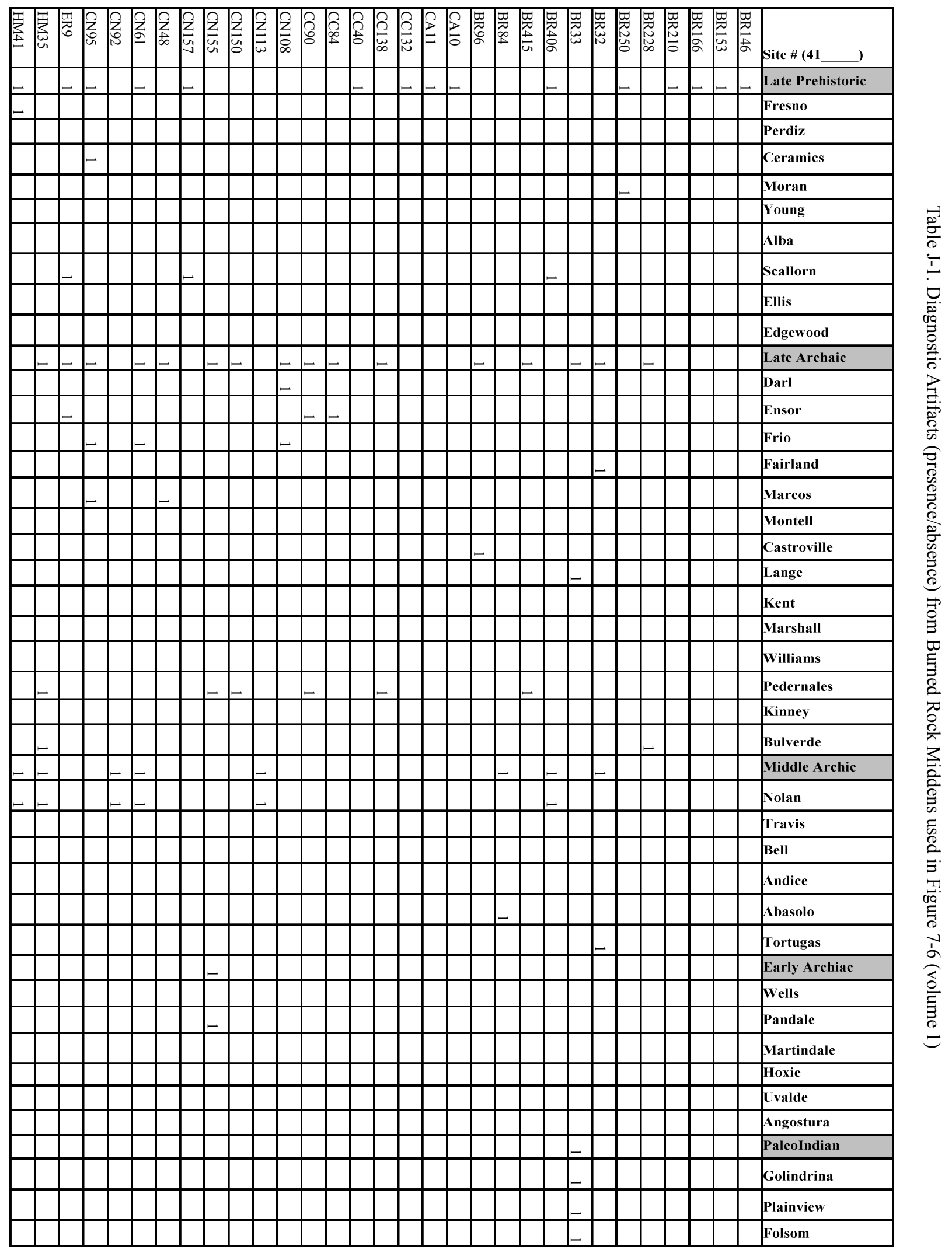




\begin{tabular}{|c|c|c|c|c|c|c|c|c|c|c|c|c|c|c|c|c|c|c|c|c|c|c|c|c|}
\hline \begin{tabular}{|l|l}
$\vec{Q}$ & $\vec{Q}$ \\
$\vec{N}$ & 0 \\
$N$ & 0 \\
\end{tabular} & 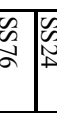 & 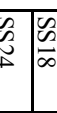 & $\begin{array}{l}\frac{\Omega}{\omega} \\
\omega \\
\omega\end{array}$ & \begin{tabular}{|l|}
$\mathscr{w}$ \\
$\tilde{N}$ \\
\multirow{2}{*}{}
\end{tabular} & $\mid \begin{array}{l}\tilde{\tilde{a}} \\
\tilde{\sigma} \\
0\end{array}$ & & & $\bar{z}$ & 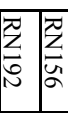 & 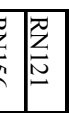 & $\mid \widetilde{Z}$ & 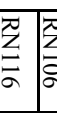 & 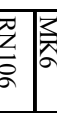 & 宗 & 定 & 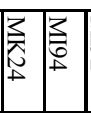 & 通 & \begin{tabular}{|l|l|}
3 & 3 \\
& $\infty$ \\
\end{tabular} & 存 & \begin{tabular}{l|l} 
\\
\multirow{3}{3}{}
\end{tabular} & 人) & 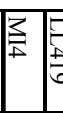 & \begin{tabular}{l|l} 
& $E$ \\
& $E$ \\
& $F$ \\
\end{tabular} & Site \# (41 \\
\hline - & - & & _ & & _ & - & - & - & _ & & & & - & _ & - & & & - & & - & - & - & - & Late Prehistoric \\
\hline & & & & & & & & & & & & & & & & & & & & & & & & Fresno \\
\hline & & & & & & & & - & & & & & & & & & & . & & & & & & Perdiz \\
\hline & & & & & - & & & & - & & & & & & & & & - & & & & - & & Ceramics \\
\hline & & & & & & & & & & & & & & & & & & . & & & & & & Moran \\
\hline & & & & & & & & & & & & & - & & & & & & & & & & & Young \\
\hline & & & & & & & & & & & & & & & & & & & & & & & & Alba \\
\hline & & & & & & & & & & & & & & & & & & & & - & & & - & Scallorn \\
\hline & & & & & & - & & & & & & & & & & & & & & & & & & Ellis \\
\hline & & & & & & - & & & & & & & & _ & & & & & & & & & & Edgewood \\
\hline & & - & & & - & - & & - & - & - & & - & 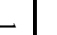 & & & 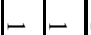 & 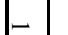 & - & & & - & & - & Late Archaic \\
\hline & & & & & & - & & & - & ـ & & & - & & & . & . & & & & . & & - & Darl \\
\hline & & & & & & . & & & & & & & . & & & . & & & & & 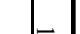 & & 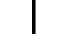 & Ensor \\
\hline & & - & & & & _ & & & & & & & . & & & _ & & & & & & & - & Frio \\
\hline & & & & & & & & - & & & & & . & & & & & & & & & & . & Fairland \\
\hline & & & & & & _ & & & & & & & - & & & & & & & & & & & Marcos \\
\hline & & & & & & & & & & & & & 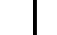 & & & & & & & & & & & Montell \\
\hline & & & & & & & & & & & & & . & & & & & & & & & & & Castroville \\
\hline & & & & & & - & & & & & & & 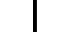 & & & & & & & & & & . & Lange \\
\hline & & & & & & & & & & & & & & & & & & 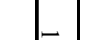 & & & & & & Kent \\
\hline & & & & & - & & & & & - & & & & & & & & & & & & & & Marshall \\
\hline & & & & & & & & & & & & & & & & & & & & & & & & Williams \\
\hline & & & & & & _ & & & & & & _ & & & & - & - & _ & & & & & & Pedernales \\
\hline & & & & & & & & & & & & 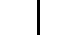 & & & & & & & & & & & & Kinney \\
\hline & & & & & & & & & & & & & - & & & & & & & & & & & Bulverde \\
\hline & & - & & & & & & & & & - & & - & - & & - & & & & & & & - & Middle Archic \\
\hline & & 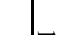 & & & & & & & & & 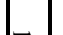 & & 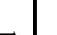 & & & & & & & & & & 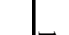 & Nolan \\
\hline & & & & & & & & & & & & & & & & - & & & & & & & . & Travis \\
\hline & & & & & & & & & & & & & & & & & & & & & & & & Bell \\
\hline & & & & & & & & & & & & & & & & & & & & & & & & Andice \\
\hline & & & & & & & & & & & & & & - & & & & & & & & & & Abasolo \\
\hline & & & & & & & & & & & & & & & & & & & & & & & & Tortugas \\
\hline & & & & - & & & & & & & - & & & & & & & & - & & & & & Early Archiac \\
\hline & & & & - & & & & & & & & & & & & & & & & & & & & Wells \\
\hline & & & & & & & & & & & - & & & & & & & & & & & & & Pandale \\
\hline & & & & & & & & & & & & & & & & & & & - & & & & & Martindale \\
\hline & & & & & & & & & & & & & & & & & & & & & & & & Hoxie \\
\hline & & & & & & & & & & & & & & & & & & & & & & & & Uvalde \\
\hline & & & & & & & & & & & & & & & & & & & & & & & & Angostura \\
\hline & & & & & & & & & & & & & & & & & & & & & & & & PaleoIndian \\
\hline & & & & & & & & & & & & & & & & & & & & & & & & Golindrina \\
\hline & & & & & & & & & & & & & & & & & & & & & & & & Plainview \\
\hline & & & & & & & & & & & & & & & & & & & & & & & & Folsom \\
\hline
\end{tabular}




\begin{tabular}{|c|c|c|c|c|c|c|c|c|c|c|c|c|c|c|c|c|c|c|c|c|c|c|c|c|c|c|}
\hline & $\mid \begin{array}{ll}\mid \\
3 \\
0\end{array}$ & 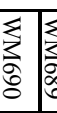 & \begin{tabular}{|l|} 
\\
3 \\
3 \\
0 \\
0 \\
0
\end{tabular} & \begin{tabular}{|l|l}
$\mid$ \\
2 \\
2 \\
2 \\
2
\end{tabular} & \begin{tabular}{l|l} 
& \\
3 & 3 \\
2 & 3 \\
2 & \\
2
\end{tabular} & 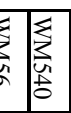 & 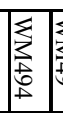 & 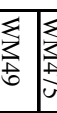 & 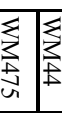 & 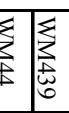 & 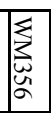 & 恳 & & 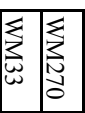 & 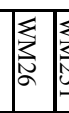 & 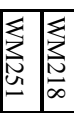 & 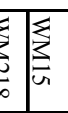 & 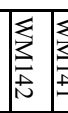 & \begin{tabular}{l|l} 
& \\
3 & 3 \\
& 0
\end{tabular} & \begin{tabular}{|l|} 
\\
3 \\
\end{tabular} & 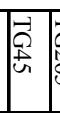 & $\overrightarrow{\widehat{A}}$ & 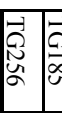 & & & Site \# (41 \\
\hline & & & $\ldots$ & & - & & - & - & - & & - & - & & & & - & & - & & _ & - & & - & - & - & Late Prehistoric \\
\hline & & & & & & & & & & & & & & & & & & & & & & & & & & Fresno \\
\hline & & & - & & - & & & & & & & & & & & & & & & & - & & & 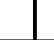 & & Perdiz \\
\hline & & & & & & & & & & & & & & & & & & & & - & - & & & - & & Ceramics \\
\hline & & & & & & & & & & & & & & & & & & & & & & & & & & Moran \\
\hline & & & & & & & & & & & & & & & & & & & & & & & & & & Young \\
\hline & & & - & & & & & & & & & & & & & & & & & & & & & & & Alba \\
\hline & & & _ & & & & & - & & & & _ & & & & & & & & & & & & & & Scallorn \\
\hline & & & & & & & & & - & & & & & & & & & & & & & & & & & Ellis \\
\hline & & & & & & & & & & & & & & & & & & & & & & & - & & & Edgewood \\
\hline - & - & & - & - & - & - & & & - & - & & - & - & $-t_{-}$ & & - & - & & - & 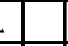 & & - & & 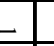 & & Late Archaic \\
\hline & & & - & & & & & & & & & & - & - & & & - & & & & & & & & & Darl \\
\hline$=$ & - & & - & & 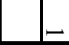 & - & & & & & & & - & - & & & 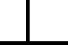 & & & & & & & & & Ensor \\
\hline- & & & 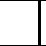 & & & & & & & & & & & & & & - & & & & & 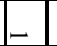 & & & & Frio \\
\hline & & & - & & - & 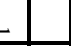 & & & & & & & & & & & - & & & & & & & & & Fairland \\
\hline & & & 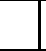 & & & & & & & - & & & & & & & 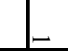 & & & & & & & & & Marcos \\
\hline & & & - & & & & & & & & & & & & & & 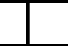 & & & & & & & & & Montell \\
\hline & & & - & & & & & & & - & & & & - & & & - & & - & 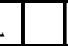 & & & & & & Castroville \\
\hline & & & - & & & & & & & & & & & & & & L & & & & & & & & & Lange \\
\hline & & & & & & & & & & & & & & & & & & & & & & & & & & Kent \\
\hline & & & - & & & & & & & - & & & & & & & - & & & & & & & & & Marshall \\
\hline & & & $\ldots$ & & & & & & & & & & & & & & - & & & & & & & & & Williams \\
\hline & - & & 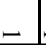 & - & & 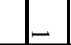 & & & & - & & 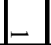 & & & & - & - & & - & & & & & & & Pedernales \\
\hline & & & 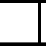 & & & & & & & & & & & & & & 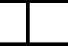 & & & & & & & & & Kinney \\
\hline & & & 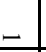 & & & & & & & 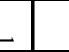 & & 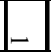 & & & & & - & & - & . & & & & - & & Bulverde \\
\hline - & & - & - & & & & - & & & - & & & & & - & & - & & & & & & & & & Middle Archic \\
\hline & & - & - & & & & & & & - & & & & & & & 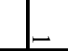 & & & & & & & & & Nolan \\
\hline & & & & & & & - & & & & & & & & & & 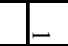 & & & & & & & & & Travis \\
\hline$=$ & & & & & & & & & & & & & & & & & 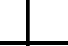 & & & & & & & & & Bell \\
\hline & & - & & & & & & & & & & & & & & & & & & & & & & & & Andice \\
\hline & & & & & & & & & & & & & & & & & - & & & & & & & & & Abasolo \\
\hline & & & & & & & & & & & & & & & 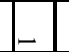 & & & & & & & & & & & Tortugas \\
\hline & & - & - & & & & & & & - & & & & & & & - & & & & & & & & & Early Archiac \\
\hline & & & & & & & & & & & & & & & & & & & & & & & & & & Wells \\
\hline & & & 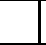 & & & & & & & & & & & & & & & & & & & & & & & Pandale \\
\hline & & - & - & & & & & & & - & & & & & & & & & & & & & & & & Martindale \\
\hline & & & - & & & & & & & & & & & & & & 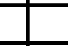 & & & & & & & & & Hoxie \\
\hline & & & - & & & & & & & & & & & & & & - & & & & & & & & & Uvalde \\
\hline & & & L & & & & & & & & & & & & & & & & & & & & & & & Angostura \\
\hline & & & & & & & & & & & & - & & & & & & & & & & & & & & PaleoIndian \\
\hline & & & & & & & & & & & & & & & & & & & & & & & & & & Golindrina \\
\hline & & & & & & & & & & & & - & & & & & & & & & & & & & & Plainview \\
\hline & & & & & & & & & & & & & & & & & & & & & & & & & & Folsom \\
\hline
\end{tabular}




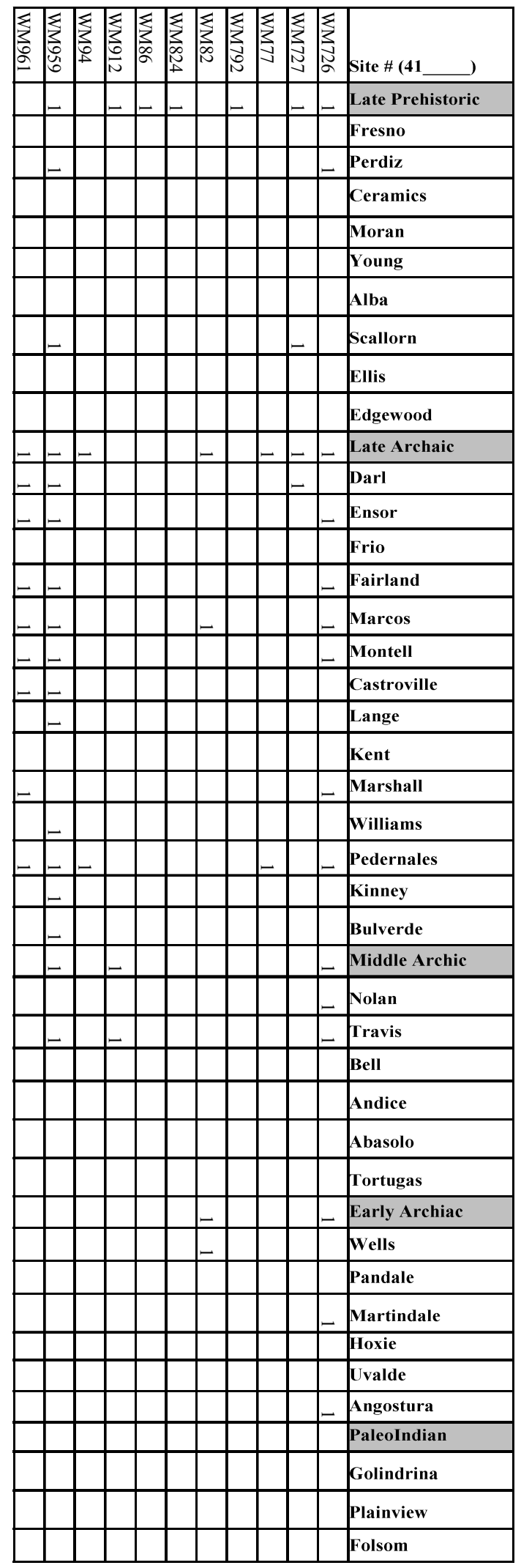

